
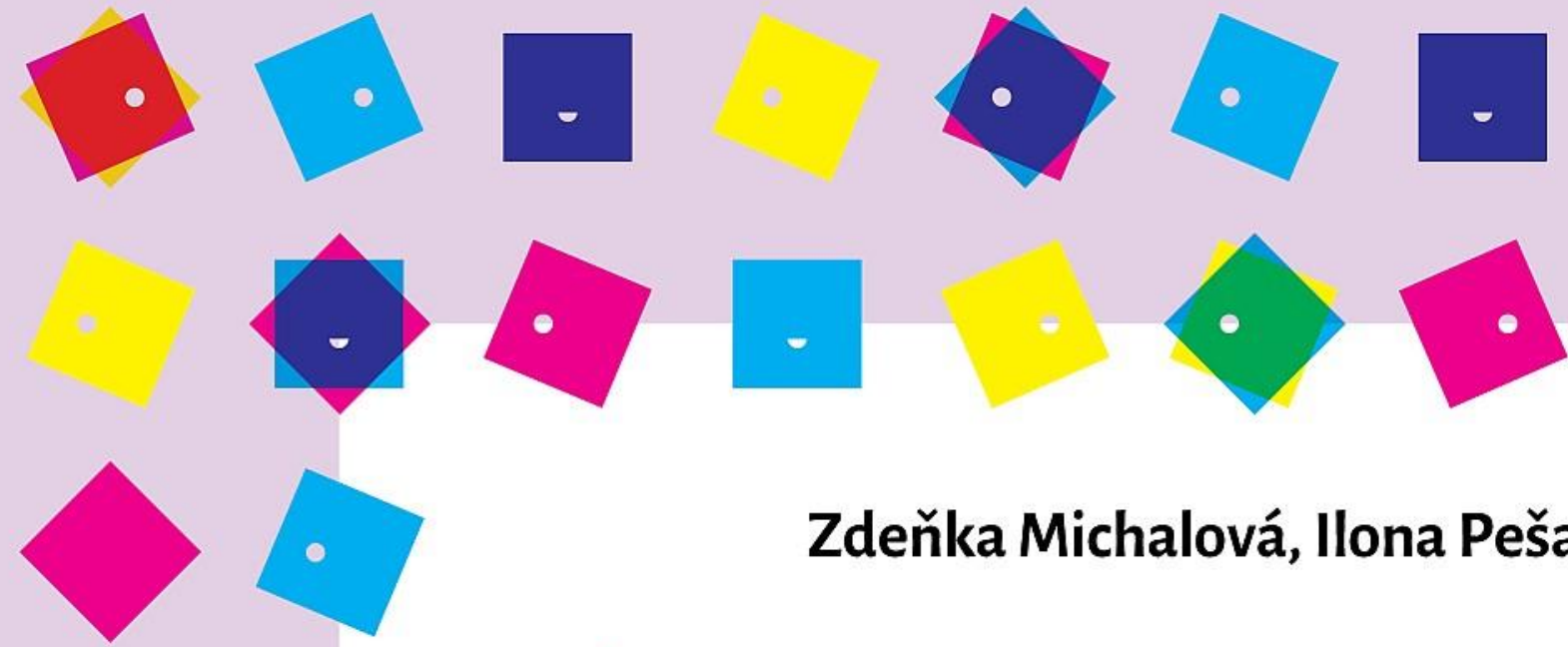

Zdeňka Michalová, Ilona Pešatová a kol.
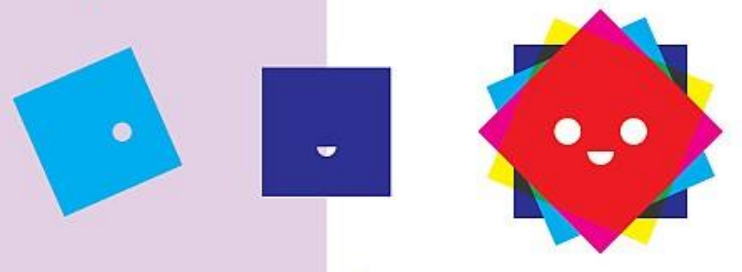

\title{
DETERMINANTY INKLUZIVNÍHO VZDĚLÁVÁNÍ DĚTí S ADHD
}
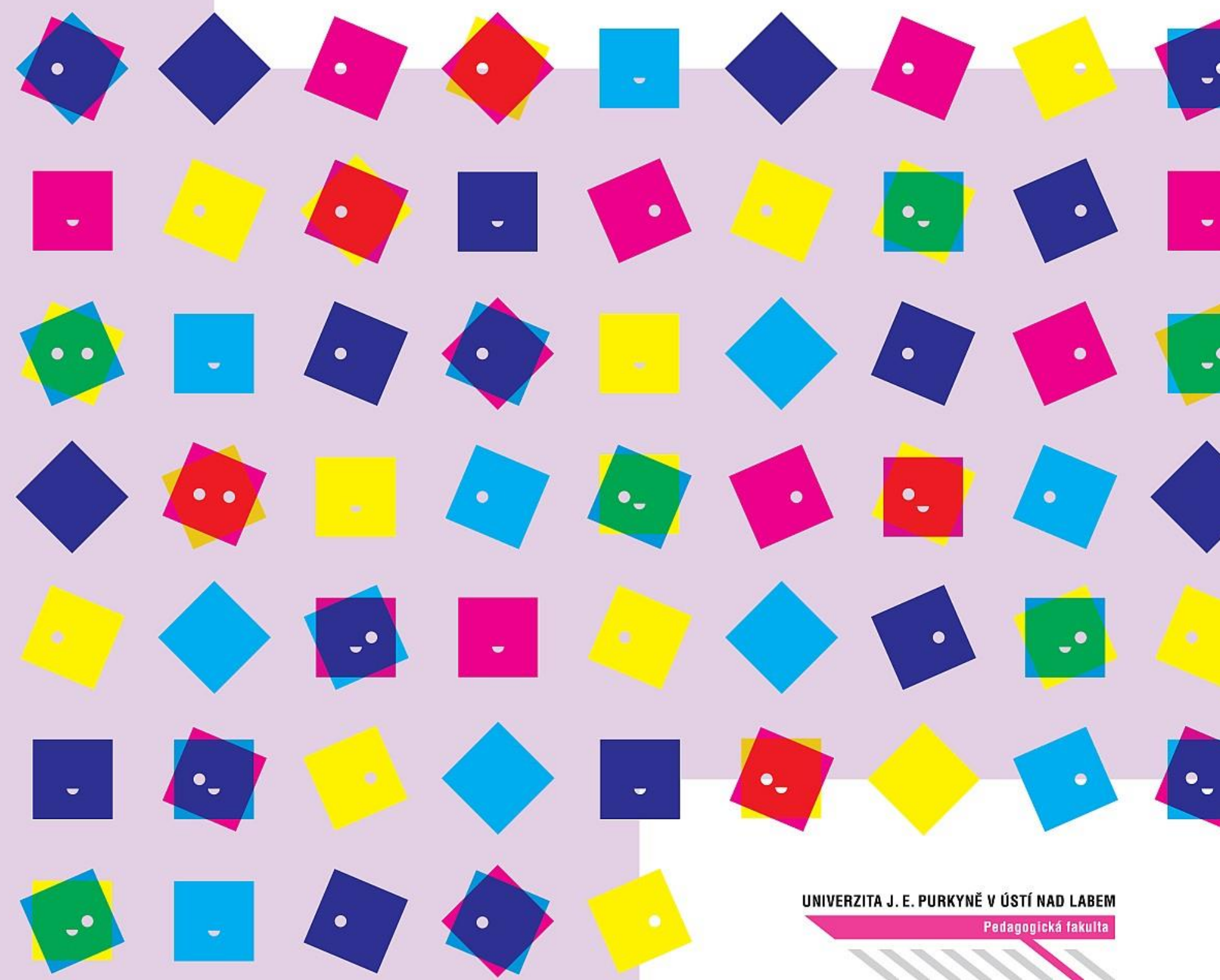


Univerzita J. E. Purkyně v Ústí nad Labem

\section{DETERMINANTY}

\section{INKLUZIVNÍHO VZDĚLÁVÁNÍ \\ DĚTÍ S ADHD}

Zdeňka Michalová, Ilona Pešatová a kol. 
Autorský kolektiv

Mgr. Vlastimil Chytrý, Ph.D.

PhDr. et. Mgr. Zdeňka Michalová, Ph.D.

RNDr. Pavel Pešat, Ph.D.

doc. PhDr. PaedDr. Ilona Pešatová, Ph.D.

Vzor citace

MICHALOVÁ, Z., PEŠATOVÁ, I. a kol. 2015. Determinanty inkluzivního vzdělávání dětí s ADHD. Brno: Tribun EU. 239 s. ISBN 978-807414-934-4.

Védecký redaktor

doc. PhDr. Jiř́i Škoda, Ph.D.

Recenzenti

doc. PhDr. Věra Vojtová, Ph.D.

doc. PhDr. Vratislava Černíková, CSc.

Tato publikace vznikla v rámci projektu Cesta $k$ inkluzi: od segregace k pozitivní diverzitě ve školství, reg. č. projektu CZ.1.07/1.2.00/47.0008, který byl spolufinancován z Evropského sociálního fondu a státního rozpočtu České republiky.

(C) Univerzita J. E. Purkyně v Ústí nad Labem, 2015

ISBN 978-80-7414-934-4 (váz./brož.)

ISBN 978-80-7414-962-7 (CD/on-line)

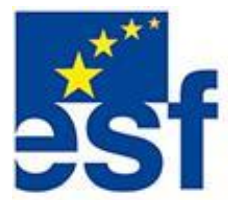

evropský sociální fond $v$ ČR
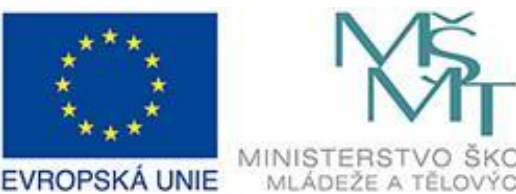

MINISTERSTVO ŠKOLSTVI
MLADEZE A TELOVYCHOVY

OP Vzděláváni
pro konkurenceschopnost

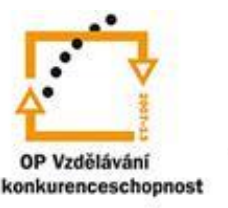

UNIVERZITA

J.E.PURKYNĚ VÚSTÍ NAD LABEM INVESTICE DO ROZVOJE VZDËLÁVÁNÍ

Projekt Cesta k inkluzi: od segregace k pozitivní diverzitě ve školství, reg. Č. CZ. 1.07/1.2.00/47.0008, je spolufinancován z Evropského sociálního fondu a státního rozpočtu Ceské republiky. 


\section{Obsah}

Úvod

1 Charakteristika poruch pozornosti s hyperaktivitou................ 11

2 Vývojová variabilita dětí s ADHD .......................................... 29

2.1 Intervence, terapie a léčba ............................................... 37

3 Komorbidita ADHD a specifických poruch učení...................... 39

3.1 Druhy specifických poruch učení ....................................... 41

3.1.1 Dyslexie..................................................................... 41

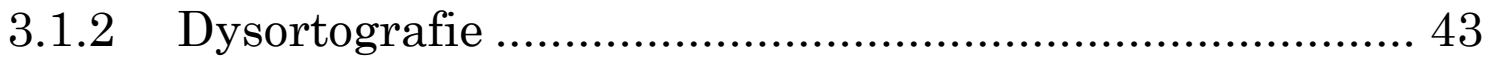

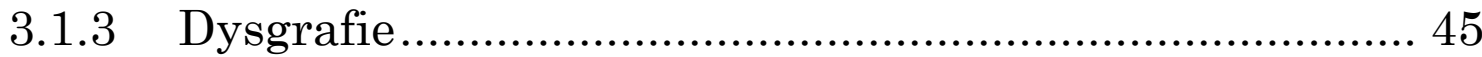

3.1.4 Dyskalkulie ............................................................ 46

3.1.5 Př́ibuzné poruchy................................................... 47

3.1.6 Specifické vývojové poruchy učení v MKN-10 .............. 50

4 Etické zásady sdělování diagnózy a proces jejího přijetí rodiči .. 51

5 Zásady intervence $u$ jedinců s ADHD..................................... 55

5.1 Děti s ADHD v mateřské škole ....................................... 62

5.2 Rámcový vzdělávací program pro předškolní vzdělávání .... 65

5.3 Tematické členění osobnostní a sociální výchovy................ 70

6 Dítě s ADHD a digitální technologie ....................................... 81

7 Osobnost učitele v procesu inkluzivní edukace.......................... 95

8 Determinanty ADHD - výzkumné šetření............................. 105

8.1 Výzkumné nástroje ...................................................... 107

8.1.1 Posuzovací škála KADDS ........................................... 108

8.1.2 Reliabilita, validita a stabilita KADDS ...................... 110

8.2 Dotazníkové šetření ...................................................... 112

8.2.1 Př́prava, distribuce a zpracování dotazníku se škálou KADDS. 112

8.2.2 Použité statistické metody zpracování......................... 113

8.2.2.1 Označení statistických veličin ............................................115 
8.3 Výsledky šetření KADDS .......................................... 115

8.3.1 Popisná statistika ..................................................... 118

8.3.1.1 Genderové složení respondentů.........................................118

8.3.1.2 Věková struktura respondentů ........................................119

8.3.1.3 Délka praxe respondenta ..................................................120

8.3.1.4 Nejvyšší dosažené vzdělání respondenta..........................121

8.3.1.5 Pracovní zařazení respondenta ve škole.............................122

8.3.1.6 Druh školy, na které respondent působí.............................. 124

8.3.1.7 Zkušenosti respondenta ze školní praxe............................124

8.3.1.8 Zkušenosti respondenta ze soukromého života ................125

8.3.1.9 Sebehodnocení znalostí o ADHD.....................................126

8.3.1.10 Didaktická forma získávání dalších znalostí o ADHD....127

8.3.2 KADDS skóry a analýza znalostí pedagogů o ADHD ... 128

8.3.2.1 Reliabilita KADDS skórů.................................................... 133

8.3.3 KADDS skóry různých skupin respondentů................ 134

8.3.3.1 Závislost KADDS skóru na vzdělání respondenta ...........135

8.3.3.2 Závislost KADDS skóru na pracovním zařazení respondenta...136

8.3.3.3 ZávislostKADDS skóru na typu š̉koly, nakteré respondent pracuje 137

8.3.3.4 Závislost KADDS skóru na zkušenostech s žáky s ADHD.138

8.3.3.5 Závislost KADDS skóru na zkušenostech s jedinci s ADHD .139

8.3.3.6 Závislost KADDS skóru na sebehodnocení .......................140

8.3.3.7 Závislost KADDS skóru na potřebě dalšího sebevzdělávání.141

8.3.3.8 Dílčí shrnutí a doporučení pro pedagogickou praxi..........141

8.3.4 Úspěšnost položek ve škále KADDS ........................... 142

8.3.5 Komparace se zahraničními výsledky ......................... 149

9 Př́́klady dobré a špatné praxe............................................... 153

9.1 Příklady dobré praxe ..................................................... 155

9.1.1 Dobrá praxe - př́íklad první ...................................... 155 
9.1.2 Dobrá praxe - př́íklad druhý.................................... 156

9.1.3 Dobrá praxe - př́klad třetí ......................................... 158

9.1.4 Dobrá praxe - př́íklad čtvrtý..................................... 160

9.2 Př́klady špatné praxe ................................................... 161

9.2.1 Šppatná praxe - př́íklad první ..................................... 161

9.2.2 Špatná praxe - př́íklad druhý .................................. 164

9.2.3 Špatná praxe - př́íklad třetí...................................... 166

9.2.4 Špatná praxe - př́íklad čtvrtý .................................. 166

9.3 Názory učitelů na pedagogickou integraci ....................... 167

10 Vhodné intervenční postupy u dětí s ADHD .......................... 179

10.1 Doporučení učitelům pro práci s žáky s ADHD .................. 182

10.2 Individuální výchovný plán ........................................... 189

10.2.1 Ověřování individuálního výchovného plánu...................... 190

10.2.2 Tvorba individuálního výchovného plánu ................. 192

10.2.3 Ukázky individuálních výchovných plánů ................. 194

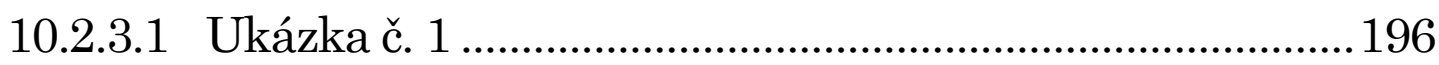

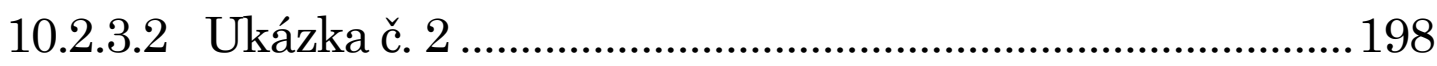

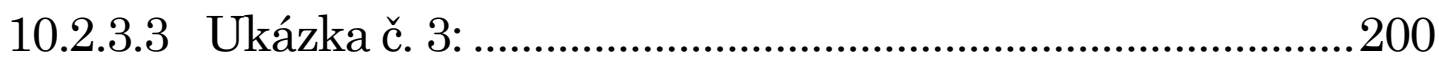

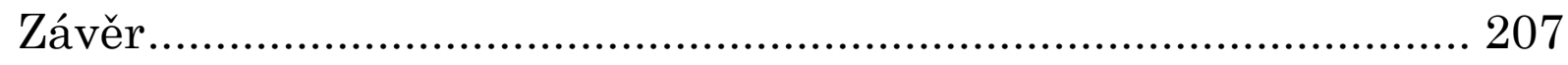

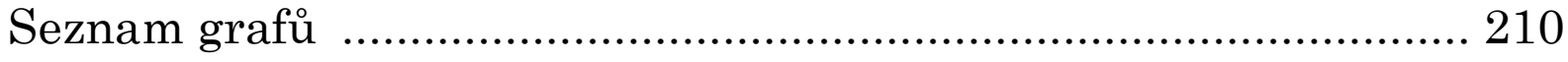

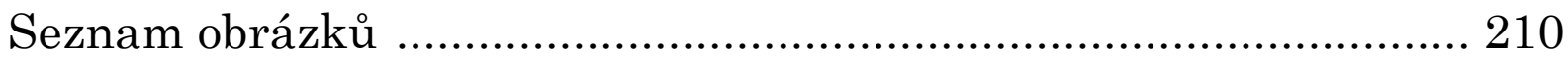

Seznam tabulek ................................................................... 211

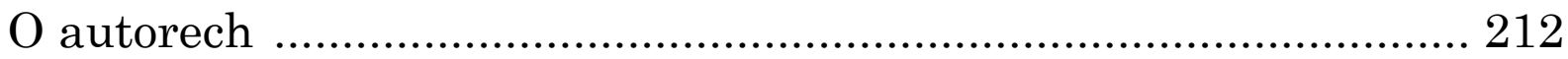

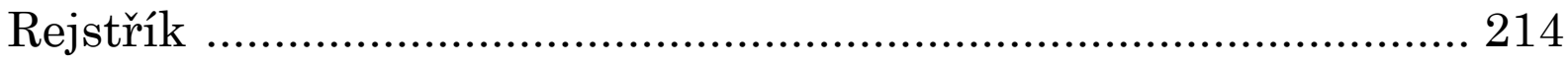

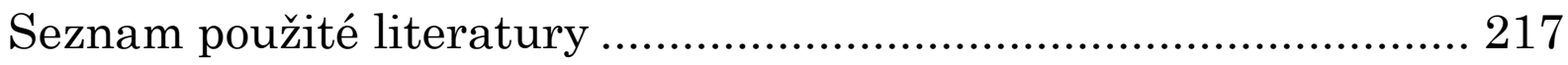

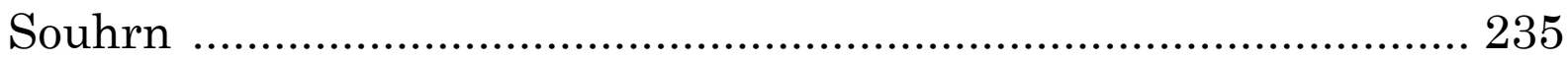

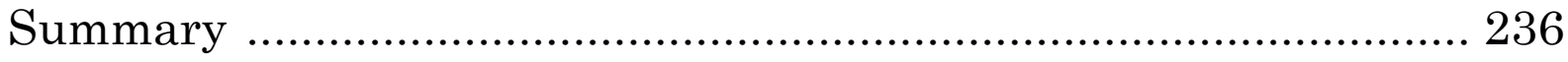

Klíčová slova / Key words ....................................................... 237 
Determinanty inkluzivního vzdèláváni dětí s ADHD 


\section{Úvod}

Mnohé děti, žáci, ale i studenti se velmi liší v tom, jak se vyrovnávají se zátěží, kterou jim přinášejí povinnosti spojené se školou. Kromě předepsaného učiva se od nich očekává, že zvládnou život v sociální skupině, tedy především v jejich kmenové třídě či v širším smyslu v celé škole. Špatný prospěch často nesouvisí s tím, že by žák nebyl vybaven dostatečnou inteligencí nebo měl sníženou kapacitu paměti. Stejně tak problémy v chování, které u dětí pozorujeme, nemusí být způsobeny tím, že se jim v rodině nikdo výchovně nevěnuje. Podkladem uváděných obtíží může být mj. porucha pozornosti s hyperaktivitou známá pod zkratkou ADHD (Attention Deficit Hyperactivity Disorder, dále jen ADHD), či porucha pozornosti (Attention Deficit Disorder, dále jen ADD), která je od roku 2013 v páté verzi Diagnostického a statistického manuálu mentálních poruch (Diagnostic and Statistical Manual of Mental Disorders 5, dále jen DSM 5) označována jako $A D H D$ I. subtypu - typ nepozorný. Nejčastějším příznakem dítěte s ADHD bývá jeho neschopnost dodržovat přiměřená pravidla chování daná společenskou normou, neschopnost po delší dobu soustředit se plně na předloženou práci či podávat dlouhodobě odpovídající učební nebo pracovní výkon, problémy s autoregulací a vnitřní motivací.)

V odborné literatuře se výše uvedené poruchy řadí mezi specifické poruchy chování (dále jen SPCH). Školský zákon (§ 16 zákona č. 561/2004 Sb., v aktualizovaném znění zákona č. 82/2015 Sb.) však tyto poruchy chování řadí do skupiny vývojových poruch chování, obdobně pak specifické poruchy učení (dále jen SPU) řadí mezi vývojové poruchy učení. Ze zákona vyplývá dětem s vývojovou poruchou chování právo na vzdělávání zahrnující podpůrná opatření, která spočívají v úpravě obsahu, forem, metod, organizace a hodnocení vzdělávání způsobem odpovídajícím jejich vzdělávacím potřebám a možnostem. V době uzávěrky této monografie však není ustálená 
legislativa upravující vzdělávání žáků s vývojovými poruchami chování ani s jinými speciálními vzdělávacími potřebami (dále jen SVP). Aktuálně se vzdělávání žáků s SVP řídí původním zněním Š̉kolského zákona, nebot většina jeho ustanovení týkající se vzdělávání žáků s SVP nabude účinnosti až za rok, ke dni 1. září 2016. Vyhláška upravující vzdělávání dětí, žáků a studentů se speciálními vzdělávacími potřebami také ještě nebyla novelizována do souladu se Školským zákonem. Tento přechodný legislativní stav však nemůže ovlivňovat podstatu specifických poruch chování dětí ani obecné speciálně pedagogické metody vzdělávání žáků s poruchami chování. Nikterak tedy neubírá na platnosti pedagogickým zjištěním, zásadám a doporučením uvedeným $\mathrm{v}$ této monografii.

Většina dětí, žáků a studentů s těmito poruchami bývá v současnosti v České republice integrována do běžného vzdělávacího proudu a jak vyplývá z předchozích úvodních informací, adekvátní výchova a vzdělávání těchto jedinců se často stává pro vyučující skutečnou výzvou a nelehkým úkolem. Erudovaný pedagog se snaží takového žáka zaujmout a vytvořit pro něj soubor vyrovnávacích či podpưrných opatření, která dítěti s ADHD umožní v běžných hodinách pracovat dle jeho skutečných schopností nezatížených poruchou. Pokud bývá $\mathrm{k}$ těmto dětem neodborně přistupováno, nejsou schopny využít při edukaci svůj skutečný potenciál rozumových schopností a mnohdy nedosáhnou ani následně vobdobí dospívání a dospělosti takové profese, k níž by ve skutečnosti byly predisponovány.

Pedagog je proto při vzdělávání žáků s ADHD považován za důležitý faktor jejich školní úspěšnosti. Přesná diagnostika uváděné poruchy bývá často velmi komplikovaná a posouzení jejích symptomů vyžaduje týmovou mezioborovou spolupráci. Učitele považujeme za velmi důležitou a nezbytnou součást tohoto týmu. Často právě oni jako první upozorňují na výskyt dílčích symptomů možné ADHD u dítěte. Následně je po nich vyžadováno zavedení podpůrných či vyrovnávacích opatření pro jeho odpovídající výuku. 
V zahraničí se touto problematikou se svými kolegy zabývá např. Mark Sciutto, Ph.D., z oddělení klinické a školní psychologie na Muhlenberg College Allentown v USA. V současné době tak existuje několik výzkumů realizovaných mezi americkými učiteli (Sciutto 2000a), které se zaměřují na jejich znalosti o ADHD a na to, jak tyto znalosti ovlivňují rozhodování pedagoga a jeho působení při edukaci žáků s ADHD. Výzkumy v jiných zemích, i když jich bylo zatím realizováno jen málo, nezávisle dokazují, že znalosti a postoje učitelů jsou v různých kulturách odlišné a závisí i na průpravě učitelů pro práci s žáky se speciálními vzdělávacími potřebami.

Proto nás zajímalo, jak jsou učitelé mateřských a základních škol včetně učitelů základních škol speciálních připraveni ke vzdělávání dětí a žáků s touto diagnózou, jaké mají znalosti a zkušenosti v dané oblasti v souvislosti s inkluzivním vzděláváním. Jednalo se v podstatě o námi stanovené tři základní determinanty dle názoru významně ovlivňující úspěšnost inkluzivní edukace ve třídách s kmenovými žáky s ADHD.

V rámci projektu Cesta $k$ inkluzi: od segregace $k$ pozitivní diverzitě ve školství, reg. č. CZ.1.07/1.2.00/47.0008, který je spolufinancován z Evropského sociálního fondu a státního rozpočtu České republiky, jsme provedli zjištění teoretických i praktických znalostí učitelů o problematice poruch pozornosti s hyperaktivitou za použití standardizovaného dotazníku KADDS (The Knowledge of Attention Deficit Disorders Scale), sestaveného, ověřeného a konsolidovaného M. Sciuttem a jeho kolegou D. Terjesenem již v roce 2004.

Kromě obecného popisu podstaty syndromu ADHD se bude monografie věnovat doporučeným vhodným přístupưm $\mathrm{k}$ dětem a žákům s touto poruchou v rámci trendů inkluzivního vzdělávání, osobnosti učitele a analýze výsledného šetření v prezentovaném výzkumu. 
Determinanty inkluzivního vzdèláváni dětí s ADHD 


\section{Charakteristika poruch pozornosti s hyperaktivitou}

Př́ičiny vzniku ADHD nelze jednoznačně stanovit. Nejvíce se odborná veřejnost shoduje na dědičnosti a biologicko-fyziologických příčinách - neurologická porucha zpracování nervových impulsů dítěte může být způsobena nejspíše zdravotními komplikacemi v těhotenství, při porodu či v raném dětství (Černá, et al. 1999; Vágnerová 1999). Poměrně prokazatelně se na vzniku syndromu uplatňuje konzumace alkoholu a kouření matky v těhotenství nebo předčasné a komplikované porody (Michalová 2000; Pešatová, 2007; Deiner 2010). Jejich vlivem dochází k jemným odchylkám ve struktuře a funkcích CNS. Vzniká nerovnováha v činnosti neurotransmiterů, které mají za úkol přenášet signály mezi různými oblastmi mozku a zajištovat tak jeho správnou a harmonickou činnost.

Častou příčinou vzniku hyperaktivity bývá také kombinace obou výše uvedených faktorů. Potvrzují to výzkumy na poli PET (pozitronová emisní tomografie), MRI (magnetická rezonance) a DNA. Prokazují, že vznik ADHD je ovlivněn spíše neurologickými a genetickými faktory než pouhými vlivy prostředí.

Comings uvádí následné pořadí příčin hyperaktivity u své klientely:

a) hereditární (genetická) dispozice,

b) prenatální a perinatální příčiny,

c) poruchy chování,

d) chronický anxiózní stav při neurotickém vývoji,

e) časné poruchy afektivního vývoje,

f) poruchy osobnosti (Comings 2005).

Současné molekulárně-genetické studie uvažují o možnosti, že se uplatňuje porucha genu pro dopaminový receptor DRD4 a genu pro dopaminový transport (Thapar, Holme, Poulton, Harrington 1999). 
Další autoři uvádějí kromě genetických příčin i jiné etiologické modely vzniku ADHD (Paclt, et al. 2007):

Kognitivní model - jedinec trpí pomalými útlumovými reakcemi, je neúnosně pomalý, jeho psychomotorické tempo nelze porovnat ani náznakově s vrstevnickou skupinou. Z vlastní praktické zkušenosti musíme dodat, že $\mathrm{v}$ kombinaci s deficity $\mathrm{v}$ behaviorální inhibici jsou základním rozeznávacím znakem v porovnání s ostatními poruchami; tento deficit je spojován s významným narušením vývoje autoregulace.

Neurobiologický model - uvádí odchylky ve stavbě a činnosti mozkových struktur.

V rodinách dětí postižených $\mathrm{ADHD}$ se významně častěji než v rodinách kontrolních vyskytuje nesoulad mezi rodiči, velký počet jedinců $\mathrm{v}$ rodině, nižší až nízký socioekonomický status rodiny, kriminalita rodičů, apod.

Biochemický model - odhaluje nedostatek neurotransmiterů, např. dopaminu, noradrenalinu a serotoninu u jedinců s ADHD. Wender, et al. (1971) se domnívali, že při dysfunkcích nefungují dobře nervové procesy. Dnes se má za to, že tyto chemické látky jsou pravděpodobně př́liš rychle odbourávány. Vědci se přiklání k tzv. mono-aminooxydační hypotéze.

Shrneme-li výše uvedené poznatky, můžeme se přiklonit k poznání, že u jedinců $\mathrm{s}$ ADHD se převážně jedná o problematiku vrozenou či částečně získanou. Dané obtíže její nositel nemůže být schopen z velké části ovlivnit. Pokud jsou dospělé osoby mající dítě $s$ ADHD do̊kladně obeznámeny s podstatou syndromu, jsou schopny vhodně zvolenou stimulací a terapií ovlivnit dotyčného jedince s hyperkinetickým syndromem tak, že se naučí tzv. s touto poruchou žít. Její symptomy pak 
nejsou zatěžující ani pro něj, ani pro jeho sociální prostředí (Michalová, Pešatová 2011, s. 47-48).

Dětem s touto poruchou ze zákona vyplývá právo na vzdělávání, jehož obsah, formy a metody odpovídají jejich vzdělávacím potřebám a možnostem.

Porucha se objeví v průběhu vývoje dítěte v podobě deficitů v oblasti kognitivních, exekutivních a percepčně-motorických funkcí, v oblasti regulace afektů a emotivity a také v sociálním přizpůsobení.

Základními třemi znaky ADHD syndromu jsou vývojově nepřiměřený stupen̆ pozornosti (poruchy pozornosti), hyperaktivity a impulzivity. Pro diagnostiku syndromu ADHD je podstatné, zda se uvedené příznaky vyskytovaly:

a) již před vstupem do školy,

b) soustavně po dobu delší než 6 měsíců,

c) výrazně častěji než u jiných dětí stejného věku.

Tyto základní příznaky dítě predisponují k mnoha dalším obtížím projevujícím se již v raném dětství. S vývojem a dozráváním centrální nervové soustavy včetně adekvátního terapeutického působení se jejich projevy navenek mění. Typickým jevem bývá neschopnost žáka dodržovat očekávaná pravidla chování či podávat po delší dobu vyrovnaný pracovní výkon. Často se proto u ADHD setkáváme kromě problémů v chování i s narůstajícími obtížemi v učení, zhruba v polovině případů pak též se specifickou poruchou učení.

Pro správnou volbu stimulace či jiného ovlivňování včetně terapeutického vedení dítěte s ADHD bývá ideální, pokud v rámci diagnózy dojde ke zjištění, o který subtyp dané poruchy se jedná.

Do roku 2013 včetně byly rozlišovány následující subtypy (Bhandary, a kol. 1997):

Subtyp I - u žáků tohoto typu převažuje tzv. kognitivní deficit charakterizovaný výraznou poruchou pozornosti a učení. Typická je pro 
ně zhoršená sociální adaptace, nejsou však agresivní. Nutně potřebují pomoci s překonáváním poruch učení, které svým rozsahem patří často mezi závažné formy.

Subtyp II - pro tento subtyp též není typickým projevem agresivita, ale výrazná převaha hyperaktivity a impulzivity včetně poruchy pozornosti. Paclt (2007) považuje za dobrou formu farmakologické pomoci podávat dětem tohoto subtypu aplikace Risperidonu v kombinaci s Ritalinem.

Subtyp III - snížený systém behaviorální inhibice u tohoto subtypu se projevuje převahou hůře zvladatelných impulzivních reakcí vedoucích k častým konfliktům. Ale ani u tohoto subtypu nebývá agresivita dominujícím doprovodným jevem. I zde se často objevují poruchy učení a případné disociální obtíže narůstající při nesprávném výchovném působení.

Subtyp IV - emoční povýšenost, sociální odtažitost, prudká reakce na odměnu i trest se vyznačuje neschopností pochopit rozdíl mezi nimi. Jedinci tohoto subtypu postrádají empatii a sociální dovednosti odpovídající jedincům daného fyzického věku. Příznačné bývají projevy agresivity, s věkem zvyšující se riziko disociálních projevů, které mohou přerůstat $\mathrm{v}$ trestnou činnost. I u tohoto subtypu dochází $\mathrm{k}$ časté kombinaci s poruchami učení.

U dítěte s narušenou pozorností nedominuje impulzivita a hyperaktivita, o to více problémů nalézáme voblasti pozornosti a v percepčně-motorických funkcích. Oslabená efektivní distribuce pozornosti při odpovídající mentální činnosti nacházející se nejméně v pásmu širší normy dle Gaussovy křivky a celkově pomalé osobní pracovní tempo bývají jeho nejčastější charakteristikou. Na rozdíl od dětí s ADHD jsou tyto děti s narušenou pozorností méně nápadné. Ve výuce většinou nevyrušují, jsou však často považovány za méně inteligentní pro svou jakousi apatičnost, pomalost v reakcích 
i v rychlosti zpracování zadané práce, skrytou nepozornost, obtíže v paměti. Mnohdy se o nich hovoří jako o dětech lenivých.

Dle již zmiňované DSM 5 se od konce roku 2013 ponejvíce rozlišují tři základní subtypy, a to:

ADHD subtyp I - typ nepozorný neboli s narušenou pozorností, dříve ADD.

ADHD subtyp II - typ hyperaktivní a impulzivní - u něj nebývá primárně pozornost narušena a z hlediska dalšího vývoje při včasné intervenci se jedná o typ nejjednodušší a sociálně nejpřijatelněji modifikovatelný.

ADHD subtyp III - typ kombinovaný, tzn., že dochází v různé hloubce u konkrétního jednotlivce jak k narušené pozornosti, tak hyperaktivitě a impulzivitě.

Rodiče a učitelé uvádějí další charakteristické znaky typické pro ADHD, které jsou v souladu se zkušenostmi Deinera (2010 in Michalová, Pešatová 2011):

- Nesoustředěnost při učení a na přidělenou činnost (u dětí např. psaní domácích úkolů).

- Neposlušnost a obtíže se zahájením práce - často tyto děti neposlechnou ani v situaci, kdy zaregistrují zcela zřejmě pokyn dospělého. Tento problém souvisí s jejich zhoršenou schopností převádět slovní instrukce do vnitřní řeči, jejímž prostřednictvím dochází $\mathrm{k}$ autoregulaci vlastního chování. Částečně tento problém některé děti kompenzují tím, že si hovoří nahlas pro sebe a tak sluchem korigují onen příkaz.

- Nepořádnost a ztrácení věcí - souvisí s neschopností či sníženou schopností plánovat činnosti a systematicky je organizovat. Protože dítě nedokáže své obtíže překonat, brzy si zvykne na problémy, které ho provázejí. Pro rodiče, učitele i ostatní spolužáky vzniká dojem, že mu to nevadí. 
- Malá vytrvalost - souvisí s oslabenými volními vlastnostmi. Děti s ADHD se obvykle nadchnou pro nějakou činnost, ale je-li dlouhodobého charakteru a ještě pokud souvisí s překonáváním překážek, jejich nadšení postupně opadá. Při neúspěchu se rychle vzdávají, nedokáží si vytvořit vnitřní mapu vedoucí $\mathrm{k}$ překonání překážky a pracovat podle ní. Naopak preferují činnosti, které vedou k rychlému získání odměny.

- Neudrží pozornost při úkolu nebo hře. Chyby z nepozornosti.

- Zvýšená urážlivost - děti s ADHD nesnáší kritiku, a to ani dobře míněnou. Berou ji jako absolutní hodnocení, které nelze změnit (,Když jsem zkazil cvičení, jsem hloupý.") Zrovna tak je pro ně naprosto nemotivující neúspěch. Problém souvisí s nízkou sociální zralostí včetně zralosti emoční (afektivní). Urážlivost vzhledem $\mathrm{k}$ proměnlivosti emocí jim však dlouho nevydrží.

- Vykonávání činnosti s nepřiměřeným výdejem energie, nedočkavost - děti s ADHD nedokáží hospodařit se svými silami. Vše dělají naplno, což způsobuje problémové zvládání především takových činností, při nichž je preferována pečlivost, důkladnost, promyšlení postupu.

- Zhoršený odhad času - děti s ADHD mají obecně zhoršený smysl pro časovou orientaci a odhad času.

- Delší čas na zklidnění - jedinci s ADHD se špatně přizpo̊sobují novým situacím, ale také v průběhu běžného školního dne jim mnohem déle trvá, např́íklad po příchodu z ranní školní družiny, než se zklidní a jsou schopni pracovat při vyučování.

- Časté nehody a úrazy, riskantní chování - souvisí s neschopností promyslet si dopředu důsledek činnosti.

- Problémy s návratem k činnosti, od které byl jedinec s ADHD vyrušen.

- Problémy se samostatnou prací, mají nevyrovnaný výkon v práci ve škole.

- Nesoustředí se na podrobnosti, pracují ledabyle, s chybami, zabývají se při jednom úkolu ještě jinými aktivitami.

- Neposlouchají instrukce, dělají zbrklé, chybné závěry. 
- Neumí si uspořádat školní práci a svoje pracovní místo, nejsou schopni udržet pořádek.

- Neumí si naplánovat úkoly, pracovní, sportovní i hrové aktivity.

- Vypadá to, že nás nevnímá, i když mluvíme přímo k němu.

- Často nelibě snáší, že se má angažovat v aktivitách, které vyžadují mentální úsilí a trpělivost, a proto některé odmítají a vyhýbají se jim.

- Často ztrácí nebo nemohou včas najít potřebné školní pomůcky, sešity, hračky, sportovní potřeby...

- Okamžitě reaguje na vnější podněty.

- Zapomíná na denní aktivity či povinnosti, které mají plnit.

Za předpokladu, že se upraví vztah okolního prostředí k dítěti s ADHD, jeho problémy se dají částečně řešit (Michalová, Pešatová, 2011, s. 45-47).

Na přičiny ADHD není v současnosti mezi odborníky sjednocený názor. Přesto se největší vliv přisuzuje dědičnosti a biologickým faktorům - např. narušenému zpracování nervových impulsů, zdravotním komplikacím v těhotenství matky nebo při porodu, užívání alkoholu a drog v těhotenství. Lze tedy říci, že jsou následně spjaty s oslabením ve funkcích a schopnostech zodpovědných za řízení, regulaci a integraci chování. Mezi tyto funkce řadíme autoregulaci, pozornost, úroveň aktivace a reaktibility, cílesměrnost, sebekontrolu, řeč (Cubillo, Halari, Smith, Taylor, Rubia 2012; Humphrey 2009; Michalová 2007; Šturma 1997).

Výskyt ADHD se v dětské populaci odhaduje v rozmezí 3-5\%, někteří autoři uvádí až 10 \% jedinců školního věku. U chlapců bývá až třikrát častější předpoklad naplnění kritérií dané diagnózy než u děvčat (nejčastěji udávaný poměr 6:2). Výrazný rozdíl v procentuálním výskytu ADHD souvisí mj. s nepřesnou diagnostikou. Př́ikladem může být studie Shaw-Zirtové a kol. (2002). Společně s kolegy zjistila, že i pediatři často špatně identifikují příznaky opozičního chování a zaměňují je za ADHD. 
Mezi nejčastější komorbidity u dětí a dospívajících s ADHD patří:

- poruchy opozičního vzdoru (zjištěna cca u 40 \% dětí s ADHD),

- specifické poruchy učení,

- specifické zpoždění ve vývoji motoriky a řeči,

- poruchy chování,

- úzkostné poruchy (až $30 \%$ dětí s ADHD),

- poruchy nálad, tikové poruchy (cca u 10 \% dětí s ADHD),

- poruchy spánku,

- fobické poruchy a afektivní poruchy, z nich především deprese a emoční poruchy,

- vyšší tendence $\mathrm{k}$ experimentům a zneužívání návykových látek zejména mezi dospívajícími s ADHD.

Různí autoři uvádějí různé procentuální údaje komorbidit s ADHD a výše uvedené hodnoty byly v literatuře zjištěny jako nejčastější. V některých případech byl rozptyl natolik velký, že hodnoty neuvádíme.

Obraz projevů poruchy bývá většinou u dívek ve srovnání s chlapci méně závažný (Gaub, Carlson, 1997; Gershon, 2002). Dnes již dokonce víme, že tato porucha nikdy u jejího nositele v dospělosti nevymizí, člověk se s ní pouze učí v průběhu svého života vyrovnat a žít. Existuje např. studie, která tvrdí, že okolo 50-65 \% dětí s diagnózou ADHD stále vykazuje výrazné př́íznaky symptomů i v dospělosti (Weiss, Hechtman 1993).

Mezinárodní statistická klasifikace nemocí a přidružených zdravotních problémů (dále jen MKN-10) uvádí následující kritéria hyperkinetické poruchy, kdy pro diagnózu je nutné, aby byly přítomny všechny jádrové příznaky onemocnění, tzv. základní symptomatická triáda poruchy pozornosti, hyperaktivity a impulzivity, která se objevuje před 7. rokem (srov. psychiatrická klasi- 
fikace DSM 5 uvádí časný začátek projevů tohoto syndromu před 12. rokem věku):

- Nepozornost - alespon̆ šest z následujících příznaků přetrvává po dobu nejméně šesti měsíců v takové míře, že má za následek nepřizpůsobivost dítěte a neodpovídá jeho vývojovému stadiu:

o často se mu nedaří pozorně se soustředit na podrobnosti nebo dělá chyby z nepozornosti ve škole, při práci nebo jiných aktivitách,

○ často neudrží pozornost při plnění úkolů nebo při hraní,

- často se zdá, že neposlouchá, co se mu říká,

- často neodkáže postupovat podle pokynů nebo dokončit školní práci, domácí práce nebo povinnosti na pracovišti, nikoli proto, že by se stavělo do opozice nebo nepochopilo zadání,

- často není s to uspořádat si úkoly a činnosti,

- často se vyhýbá úkolům, např́íklad domácím pracím, které vyžadují soustředěné duševní úsilí,

- často ztrácí věci potřebné pro vykonávání určitých úkolů nebo činností, například školní pomůcky, pera, knížky, hračky nebo nástroje,

○ často se dá lehce vyrušit vnějšími podněty,

○ často je při běžných denních činnostech zapomnětlivé.

- Hyperaktivita - alespon̆ tř̀i z následujících příznaků hyperaktivity přetrvávají po dobu nejméně šesti měsíců v takové míře, že mají za následek nepřizpůsobivost dítěte a neodpovídají jeho vývojovému stadiu:

- často bezděčně pohybuje rukama nebo nohama nebo se vrtí na židli,

- při vyučování nebo v jiných situacích, kdyby mělo zůstat sedět, vstává ze židle, 
○ často pobíhá nebo popochází v situacích, kdy je to nevhodné, u dospívajících dětí nebo u dospělých se mohou vyskytovat pouze pocity neklidu,

o často je nadměrně hlučné při hraní nebo má potíže chovat se tiše při odpočinkových činnostech,

o trvale vykazuje nadměrnou motorickou aktivitu, kterou není schopno zásadně podřizovat společenským podmínkám nebo požadavkům.

- Impulzivita - alespon̆ jeden z následujících př́iznaků impulzivity přetrvává po dobu nejméně šesti měsíců v takové míře, že má za následek nepřizpůsobivost dítěte a neodpovídá jeho vývojovému stadiu:

○ často vyhrkne odpověd’ dřív, než byla dokončena otázka,

○ často nevydrží stát v řadě nebo nedokáže počkat, až na ně přijde řada při hře nebo v kolektivu,

○ často přerušuje ostatní nebo se jim plete do hovoru, skáče jim do řeči, ruší je při hře atd.,

o bez ohledu na společenské zvyklosti a omezení nadměrně mluví.

Brněnský psychiatr Theiner sestavil přehledná schémata typických příznaků ADHD:

- v dětství, viz tabulka 1 na následující straně,

- v dospělosti (včetně období dospívání), viz tabulka 2 na následující straně. 
Tabulka 1: Typické příznaky ADHD v dětství (Theiner 2012)

\begin{tabular}{|l|}
\hline Typické přiznaky ADHD \\
v dětství \\
\hline Nepozornost \\
\hline • obtížně se koncentruje na úkoly, \\
• nedokáže udržet pozornost, \\
• zdá se, že neposlouchá, \\
• nedokončuje započaté činnosti, \\
•vyhýbá se úkolům s velkým \\
mentálním úsilím, \\
•je nepořádný, \\
•je roztržitý, ztrácí věci, \\
zapomíná. \\
\hline Hyperaktivita \\
• neposedný, vrtí se, nevydrží \\
sedět na místě, \\
•pobíhá, \\
•vyrušuje, je hlučný, obtížně \\
zachovává klid, \\
• poŕád je v pohybu, \\
• mnohomluvný.
\end{tabular}

Tabulka 2: Typické příznaky ADHD v dospělosti (včetně dospívání) (Theiner 2012)

\begin{tabular}{|c|}
\hline $\begin{array}{l}\text { Typické přiznaky ADHD } \\
\text { v dospělosti (a v dospívání) }\end{array}$ \\
\hline Nepozornost \\
\hline $\begin{array}{l}\text { • špatné plánování a nakládání } \\
\text { s časem, } \\
\text { • problémy se započetím a } \\
\text { dokončením úkolu, problémy } \\
\text { přecházet mezi úkoly, } \\
\text { • prokrastinace - odkládání } \\
\text { nepříjemných úkolů, } \\
\text { • vyhýbání se činnostem vyžadujícím } \\
\text { soustředění. }\end{array}$ \\
\hline Hyperaktivita \\
\hline $\begin{array}{l}\text { • nepříjemný vnitřní pocit neklidu, } \\
\text { potřeby stále něco konat, } \\
\text { • drobné příznaky zevního neklidu, } \\
\text { např. poklepávání nohou, rukou, } \\
\text { • zapojení do mnohých aktivit, } \\
\text { workoholismus, } \\
\text { • snadno se nudí a vyhýbají se } \\
\text { situacím, kdy „není co dělat“. }\end{array}$ \\
\hline Impulzivita \\
\hline $\begin{array}{l}\text { - nízká frustrační tolerance, } \\
\text { •časté změny zaměstnání, partnerů, } \\
\text { • rychlá jízda a pokuty za dopravní } \\
\text { přestupky, } \\
\text { • rychlá rozhodnutí, netolerance } \\
\text { nejistoty, } \\
\text { - skákání do řeči. }\end{array}$ \\
\hline Emoční dysregulace \\
\hline
\end{tabular}


ADHD patří mezi tzv. spektrální poruchy proto, že se u různých lidí vyskytuje $\mathrm{v}$ různých stupních závažnosti. Neexistují absolutně správné diagnostické testy pro určení ADHD, symptomy se různí podle věku, situace a podmínek, mohou být zakryty příznaky jiné poruchy nebo dílčí příznaky mohou být určeny jako ADHD, ačkoli jsou způsobeny jinou poruchou (Munden 2008). Důležité však je, aby se dítěti, které má problém, dostalo pomoci co nejdříve. Aby mohla být zahájena správná komplexní terapie, jedinec musí projít diagnostickým procesem.

Diagnostika žáků v procesu edukace se týká především a v prvé linii učitelů, současně však psychologů, speciálních pedagogů, lékařů, nelze opomenout částečně rodiče a v některých případech, především ve starším školním věku, samotné děti. Ubírá se zejména směrem klinického sledování projevů dítěte. Na odborném pracovišti vychází z jeho rodinné a osobní anamnézy. Při psychologickém a speciálně pedagogickém vyšetření dítěte zmapujeme jeho kognitivní a percepčně-motorické funkce, rozebereme profil schopností, emočně sociální a pracovně volní dispozice.

Mnoho autorů, našich i zahraničních, doporučuje používat jako základní součást diagnostiky ADHD psychologický test WISC-III (Wechsler 2002). Tito autoři společně s Wechslerem udávají příznačná vodítka popisující příčiny selhání dětí s ADHD v dílčích subtestech:

- Vědomosti - výkon může ovlivnit nesoustředěnost, nízká koncentrace pozornosti, labilita dítěte, opožděný vývoj řeči. Nelze podcenit i silnou sociokulturní podmíněnost.

- Podobnosti - subtest bývá náročný na abstraktní myšlení, tvoření pojmů, konceptualizaci a integraci. Děti s ADHD mohou vykazovat nižší výkon především z důvodů zhoršené koncentrace pozornosti a schopnosti mentální organizace.

- Počty - zde bývají nastaveny zvýšené nároky na auditivní pozornost a pamět. Dítě pracuje bez zrakové opory. Impulzivita a nízká koncentrace pozornosti ovlivní negativně výsledek celého subtestu. 
- Slovník - zvýšené nároky jsou kladeny na jazykové schopnosti, dovednosti a myšlenkové operace s nimi spojené. Neúspěch v tomto subtestu odráží narušenou koncentraci pozornosti a popřípadě obtíže v integraci percepce.

- Porozumění - soustředí se na sociální úsudek probanda, na jeho schopnost řešit běžné sociální situace každodenního života. Nižší skór poukazuje na obtíže v oblasti socializace těchto dětí.

- Opakování čísel - jedná se o jednu z nejobtížnějších zkoušek pro dítě s ADHD. Nízké skóre v tomto subtestu souvisí s nízkou koncentrací pozornosti, rychlým nástupem únavy, impulzivitou.

- Doplňování obrázků - souvisí s kvalitou zrakově-percepční diskriminace. Výkon zde negativně ovlivňuje slabá koncentrace pozornosti a porucha zrakové percepce.

- Kódování - zkouška nás informuje o úrovni vizuo-motorické koordinace, psychomotorického tempa a koncentrace pozornosti včetně částečně krátkodobé paměti. Na výkon působí opět snížená koncentrace pozornosti, impulzivita, porucha zrakové percepce.

- Ǩazení obrázků - postihuje úroveň neverbálního uvažování. Výkon bývá snížen především celkovou nižší úrovní rozumových schopností frekventanta, dále poruchou zrakové percepce, poruchou pozornosti, nízkou sociální zralostí.

- Kostky - subtest mapuje míru obecné inteligence, analytickosyntetické procesy. Selhání souvisí s poruchou zrakové percepce, prostorové orientace, narušenou pozorností, impulzivitou, může být indikátorem organicity (Paclt 2007, s. 64).

- Skládanky - zaměřují se na vizuo-motorickou koordinaci a schopnost systematické a plánovité činnosti. Selhání opět souvisí s poruchou percepce, prostorové orientace, narušenou pozorností, impulzivitou.

- Hledání symbolů - subtest je ukazatelem hyperkinetického syndromu. Nedostatky v jeho řešení souvisí s narušenou vizuomotorickou koordinací, pracovním tempem, oslabenými volními vlastnostmi (vytrvalost), neklidem, nesoustředěností. 
- Bludiště - selhání $\mathrm{v}$ tomto subtestu může indikovat nejen projevy ADHD, ale další organické obtíže.

Pro srovnání chování dítěte $\mathrm{s}$ ADHD v prostředí školy a rodiny lze v současnosti velmi dobře uplatnit metodu BRIEF (Behavior Rating Inventory of Executive Function, dále jen BRIEF), určenou pro rodiče a učitele dětí s ADHD širokého věkového rozpětí (5-18 let). Posuzuje kvalitu exekutivních funkcí chování dětí. Kromě ADHD je samozřejmě využitelná u dětí s poruchami učení, poruchami pozornosti, traumatickými poraněními mozku, pervazivními vývojovými poruchami, depresí a dalšími vývojovými, neurologickými, psychiatrickými a jinými obtížemi. Každá z verzí dotazníku pro rodiče i pro učitele zahrnuje 86 položek v 8 škálách, které hodnotí různé aspekty exekutivních funkcí:

- Inhibici, která mapuje schopnost dítěte zadržet určité chování, nebo nejednat impulzivně.

- Přesun pozornosti, čili schopnost svobodně a vědomě přecházet $\mathrm{z}$ jedné situace, aktivity či problému $\mathrm{k}$ druhému podle toho, jak to vyžadují okolnosti.

- Emoční kontrolu, která je zaměřená na emocionální oblast a hodnotí schopnost dítěte regulovat emoční reakce.

- Iniciativu mapující schopnost začít úkol nebo aktivitu, samostatně tvořit, mít nápady, řešit problémy a umět na ně reagovat.

- Pracovní pamět, která měří kapacitu dítěte udržet informace v paměti za účelem splnění určitého úkolu.

- Plánování a organizaci, která hodnotí schopnost dítěte organizovat si současné i budoucí úkoly. Souvisí se schopností předvídat a plánovat, stanovovat cíle a činit kroky ke splnění úkolu.

- Organizaci pomůcek, zaměřenou na dovednost udržování pořádku při práci, hře a pořádku obecně.

- Kontrolu chování, orientovanou na zvyky voblasti kontroly práce, což souvisí např́iklad se schopností zhodnotit svůj výkon během úkolu nebo po jeho ukončení. 
- Osobní funkce kontroly - jedná se například o schopnost sledování vlivu svého chování na ostatní.

Konkrétně dvě z uvedených škál, pracovní pamět a inhibice, jsou podle autorů užitečné pro rozlišení podtypů ADHD. Na základě analýzy výsledků ve výše uvedených oblastech lze stanovit:

- Index regulace chování (dále jen BRI), který se vztahuje se k problému hyperaktivity a impulsivity. Reprezentuje schopnost dítěte přesunout pozornost, modulovat emoce a chování prostřednictvím vhodné inhibice. Skládá se ze škál Inhibice, Přesun pozornosti a Emoční kontroly. Přiměřená kontrola chování je pravděpodobně nejlepší cestou $\mathrm{k}$ vhodnému metakognitivnímu řešení problémů. Kontrola chování umožňuje aktivní a systematické řešení problémů a obecně adekvátní sebekontrolu.

- Index metakognice (dále jen MI), který reprezentuje schopnost dítěte zahájit, plánovat, organizovat a udržet v pracovní paměti. Je interpretován jako schopnost kognitivně samostatně zvládat úkoly a schopnost kontrolovat svůj projev. MI se přímo vztahuje ke schopnosti dítěte aktivně řešit problémy $\mathrm{v}$ různých kontextech. Tento index se skládá ze škál: Iniciativa, Pracovní pamět, Plánování a organizace, Organizace pomůcek a Kontrola chování.

- Globální exekutivní kompozit (dále jen GEC), který je celkovým skórem, protože zahrnuje všech osm klinických škál. Je vhodné zhodnotit všechny indexy jednotlivě, protože GEC je využitelný pouze jako souhrnný výsledek (Ptáček, 2011, s. 28).

V případě potřeby, především u závažných případů, bývá rodičům následně doporučeno neurologické vyšetření se zhotovením elektroencefalografu (dále jen EEG). Rozbor záznamu z EEG vyšetření může podchytit i dílčí symptomy epileptické aktivity, kterou někteří jedinci s ADHD trpí. Neznamená to, že se u nich projevuje záchvatovité onemocnění v plném rozsahu, spíše jsou k možné záchvatovité aktivitě predisponováni přesto, že s největší pravděpodobností epilepsii nikdy mít nebudou. Jejich včasné rozpoznání je důležité pro prevenci a minimalizaci rizika vzniku záchvatové aktivity podáváním předepsané medikace. 
Ideální situace nastává, podaří-li se děti s ADHD diagnostikovat v prvních měsících školní docházky, kdy se začínají odlišovat od svých vrstevníků. Kent (in Pilařová, Kavale-Pazlarová 1999) uvádí, že ADHD se diagnostikuje před nástupem do školy pouze minimálně, protože této poruše se v předškolním věku věnuje menší pozornost jak mezi odborníky, tak mezi rodiči (Michalová 2007; Pešatová 2007). Přitom uváděná porucha může být jak podle Barkleyho (2006), tak Kenta (in Pilařová, Kavale-Pazlarová 1999) diagnostikována již od dvou let věku a jednotlivé symptomy této poruchy mohou být určeny již v prvních měsících života dítěte. Pro podežrení na přítomnost ADHD u dětí předškolního věku uvádí deset rizikových faktorů (resp. symptomů). Ke stanovení diagnózy se jich musí prokázat více najednou.

„Rizikové faktory jsou následující:

1. př́itomnost ADHD u vlastních sourozenců nebo rodičů,

2. nadměrné pohyby plodu („,kopání“) v prenatálním období,

3. dráždivé chování dítěte, které je nadměrné a obtížně ovlivnitelné nebo trvá déle než do tří měsíců věku dítěte,

4. problémy se spaním nebo s dodržováním denního režimu v prvním roce života, tyto problémy mohou přetrvávat až do předškolních let,

5. časté hyperaktivní, dezorganizované chování, které není projevem smysluplné explorace a zvídavosti nebo není očekávanou součástí specifické aktivity,

6. časté nadměrné bouřlivé afekty a výrazná emoční labilita, která je spojena i s malými podněty,

7. zhoršená adaptabilita - dítě se obtížně přizpůsobuje změně, pravidelnému rozvrhu, pobytu ve skupině i organizované aktivitě,

8. jiná vývojová opoždění (často mírného stupně) spojená s hyperaktivním chováním nebo nesoustředěností (nap̌r. pomalejší motorický či řečový vývoj, pomalejší vývoj dodržování čistoty, problémy v senzomotorické oblasti, pomalejší sociální vývoj apod.), 
9. chronické ušní infekce uváděné ve spojitosti s hyperaktivním chováním a nesoustředěností,

10. sklon k nehodovosti a malý smysl pro osobní bezpečnost a bezpečnost ostatních“ (in Pilařová, Kavale-Pazlarová 1999, s. 21).

Obecně se však lze při zamyšlení nad důležitostí aplikace pedagogické diagnostiky ve školním prostředí přidržet slov Mertina s Krejčovou (2012, s. 7), kteří upozorňují, že existují přístupy k poznávání s ambicí porozumět člověku obecně (tzv. nomotetické přístupy, veškerý kvantitativní výzkum, míry i sumativní diagnostika), zatímco jiné vycházejí a jsou důležité pro porozumění konkrétnímu jedinci (přístupy idiografické, např. kazuistika, kvalitativní výzkum, narativní přístup, formativní diagnostika). Pro edukaci konkrétního žáka představují obecné poznatky (a tedy nomotetické diagnostické přístupy) východisko, rámec, vodítka, ve kterých se učitel pohybuje, generují nové hypotézy, nicméně pro bezprostřední individuální práci s jednotlivcem jsou podstatné metody idiografické. To se týká i pedagogické diagnostiky dětí s ADHD v prostředí školy, protože je nezbytným východiskem další úspěšné edukace, tedy veškeré výuky a výchovy.

Pro propojení diagnostiky s následnou intervencí je však dle našeho názoru nejefektivnější u dětí s ADHD dynamická diagnostika. Především $\mathrm{z}$ důvodu přesvědčení o modifikovatelnosti kognitivních procesů a orientaci dítěte na průběh učení a jeho přednosti i bloky dokáže dynamická diagnostika na rozdíl od statické alespoň zčásti odstranit zkreslení způsobená projevy dané poruchy. 
Determinanty inkluzivního vzdèláváni dětí s ADHD 


\section{Vývojová variabilita dětí s ADHD}

Každý učitel a pedagogický pracovník by měl být dobře seznámen s vývojovou variabilitou dětí s ADHD. Neznalost způsobuje mnohá zbytečná dilemata $\mathrm{v}$ př́istupu $\mathrm{k}$ nim nejen ve školním prostředí. Neznalost specifik vývojového období předchozího může sehrávat negativní roli nejen v pedagogické diagnostice, ale i vintervenci. Učitelé musí působit na dítě tak, aby bylo se svou poruchou schopno žít v kolektivu ostatních, naučilo se respektovat běžné požadavky sociálního prostředí a plnit povinnosti, které mu přísluší. Pokud je člověk v některém svém vývojovém období konfrontován s náročnými mezilidskými stresy, s neuspokojením potřeby bezpečí a jistoty, absentuje u něj pocit, že je milován druhými osobami, což vyvolává frustraci citových vazeb.

Narušený psychický vývoj s různorodou markantností jednotlivých př́znaků se může projevit jako narůstající nedůvěra $\mathrm{k}$ lidem, ale i nedůvěra ve své vlastní schopnosti, citová deprivace, pocity méněcennosti. Může dojít až k úniku do izolace, či naopak k obranným postojům až agresivně podbarveným. Spočívá ve stranění se sociálním vztahům či dokonce v psychické stagnaci, z druhé strany v upozorňování na sebe tzv. za každou cenu, v obtěžujících projevech, slovních i fyzických provokacích.

Protože jedinec s ADHD se vyvíjí jinak ve srovnání s jedincem intaktním, ona jinakost dokáže dospělého pečovatele znejistit, protože zjištuje, že takovému dítěti vlastně vůbec nerozumí. Níže uvedená charakteristika má přispět k onomu porozumění, protože dojde-li k němu, bude se snižovat výskyt atypických reakcí dospělých na specifické podněty vysílané dítětem s ADHD.

\section{Novorozenecké a kojenecké období}

Nejtypičtější pro novorozence s hyperaktivitou bývá výrazná nepravidelnost v denním režimu. Provádí spoustu bezúčelných pohybů, 
které u něj mnohdy vyvolávají i nevolnosti a zvracení, nebot nevydrží v klidu odpočívat ani po jídle. Typické bývají i nepravidelnosti v množství přijaté potravy. Nepravidelně usíná, nepravidelně se probouzí, některé děti spí celkově méně, než bývá pro běžné novorozeně bez hyperaktivity typické. Někdy prospí celý den, ale v noci je aktivní, projevuje se u něj zvýšená dráždivost, více křičí nebo častěji pláče, jakoby bez do̊vodu. Atypické projevy zpo̊sobují nejistotu u osoby, která o dítě pečuje, nejčastěji se jedná o matku. Vyčítá si, že nezvládá svou mateřskou roli a přemýšlí nad svými pochybeními vůči dítěti.

Špatné výchovné působení může již v tomto vývojovém období, samožrejmě v závislosti na vrozených dispozicích dítěte, jakými jsou např. temperament či afektivní dráždivost, vést bud' k neurotickým reakcím, či dokonce $\mathrm{k}$ nastartování poruchy chování. Vágnerová s Valentovou (1991, s. 41) upozorňují na to, že k neurotizaci kojence může dojít neadekvátním krmením, kterému se dítě nemá možnost bránit, či násilným narušováním rytmu spánku a bdění. Poruchy spánku se velice snadno fixují a mohou dlouhou dobu přetrvávat. U starších kojenců, kteří bývají dispozičně dráždivější, může takový zpo̊sob zacházení vyvolat i afekt projevující se křikem, někdy dokonce spojeným s krátkodobou zástavou dýchání. Afekt je reakcí na nějaké omezení, které na dítě nelibě působí. Dítě se tak může naučit prosazovat naplňování svých potřeb.

\section{Batolecí období}

Obecně se dítě v batolecím věku učí rozumět světu a chápat jeho řád. Rozvoj dětské autonomie usnadní chápání skutečnosti, že ve světě platí určitá pravidla a že jejich prostřednictvím lze předvídat, co se kdy a za jakých podmínek bude dít.

Batolata často úporně trvají na dodržování nacvičených postupů při zacházení s nimi, například postup při oblékání musí být stále stejný, totéž při krmení apod. Přresný řád je totiž pro ně zcela srozumitelný, příjemný, dává jim jistotu, pomáhá jim chápat okolní svět. 
V tomto období u dětí s ADHD často stále přetrvává nepravidelnost $\mathbf{v}$ denním režimu. Dítě je př́liš živé, neklidné, nepravidelně usíná i během dne, v noci špatně spí. Některé děti se v noci bojí a vyžadují spát s rozsvícenou lampičkou. Nevydrží dlouho u žádné zábavy ani hry, všechny aktivity je za chvilku omrzí. Často nelze $\mathrm{v}$ tomto věku odhadnout, do jaké míry jsou přiměřeně zvídavé a do jaké míry by se mohlo jednat o hyperaktivitu. U některých dětí se již projevuje nerovnoměrný psychomotorický vývoj, některé vývojové fáze dítě vynechá a teprve po nějakém čase se $\mathrm{k}$ nim většinou vrací. Příkladem může být dítě, které na svůj věk perfektně mluví, ale má problémy s motorikou apod. Typické tedy bývá, že některé děti začnou například později chodit, pohybují se nepochopitelně zbrkle, zároveň jsou neobratné a často prodělají nějaký úraz.

Batolecí období je obdobím rozvoje samostatnosti, emancipace (tzv. období vzdoru, negativismu), ale přesto přetrvávající závislosti na matce či nejbližších dospělých. Pochopením různých sociálních rolí si dítě ujasňuje i roli vlastní a utváři si svou osobní identitu. Vývoj dítěte se projevuje i v oblasti sebeobsluhy, kde dochází k postupnému osamostatňování a menší závislosti na dospělých.

Zde se začíná u některých dětí s ADHD projevovat jejich malá zručnost. Ta ovlivní i samotnou hru, která bývá ve srovnání se stejně starými dětmi primitivnější, protože na náročnější úkony dítě s ADHD nemá trpělivost ani potřebnou šikovnost.

Oblíbenou aktivitou dětí v batolecím věku je hra s řečí. Zprvu se rozvíjí řeč pasivní, tj. porozumění, následně aktivní (aktivní užívání osvojené slovní zásoby). První slova, která mají určitý význam, dítě užívá zhruba kolem dosaženého jednoho roku života. U dětí s ADHD bývá řečový vývoj opožděn, obzvláště v přesnosti artikulace. Rodiči však bývá tento nedostatek často považován za přechodnou záležitost. Zejména pokud se matka dítěti věnuje, předpokládá, že verbální schopnosti potomka budou brzy na dobré úrovni. Rodiče ještě v tomto věkovém období často netuší, že právě jejich dítě může být k řečové opožděnosti predisponováno. 
Koncem tohoto období lze již někdy pozorovat náznaky obtíží ve vrstevnických interakcích. Zvýšená aktivita a nepozornost je charakteristická až pro $40 \%$ dětí tohoto věku a nemusí se jednat o přítomnost $\mathrm{ADHD}$. Dítě $\mathrm{s} A D H D$ však působí rušivě mezi ostatními a stává se odmítaným.

\section{Předškolní věk}

Základním úkolem tohoto období je rozvoj účelné aktivity, iniciativa dítěte však musí být odpovídajícím způsobem usměrňována a regulována. Dítě si již musí uvědomovat z hlediska chování, co si může a co si nesmí dovolit. Přijetí a zvnitřnění norem chování bývá obecně dosaženo v tomto období. Dítě dokáže reagovat pocitem viny, když nějakou normu překročí. Do tohoto stádia, v němž chápe životní řád, se však dítě s ADHD dostává pozvolněji. Potenciální konflikt mezi vlastní iniciativou a pocitem viny spojeným $\mathrm{s}$ důsledkem prováděné aktivity se dostavuje se zpožděním.

Mnoho dětí s ADHD, které již mají stanovenou diagnózu, o její příznaky na počátku tohoto období přichází (mezi 3.-4. rokem). Proto je důležité vést $v$ patrnosti, že výskyt některých symptomů ještě neznamená, že porucha bude dítě nutně provázet i v dalších letech.

Sebehodnocení předškolního dítěte bývá z důvodu nezralosti citového a rozumového vývoje závislé na hodnocení dospělých osob, dítě jejich názory přejímá.

Děti, u nichž však porucha přetrvává, bývají enormně živé, stále někde něco zkoumají, někam lezou, neustále vyžadují pozornost druhé osoby. V šesti letech bývají prakticky ve všech oblastech nepřipravené pro zahájení školní docházky.

Typická je náladovost, podrážděnost, rozmrzelost. To se projeví především v mateřské škole, kdy učitelky rodiče upozorňují na atypické projevy dítěte ve srovnání s ostatními vrstevníky. Běžně lze totiž očekávat, že dítě ve věku 3-5 let v oblasti sociálních vztahů dokáže rozlišovat různé sociální role a v souladu s jejich naplňováním 
se chovat. To bohužel pro dítě s ADHD většinou neplatí. Vztahy k lidem mívají povrchní, nezralé, mezi ostatními dětmi a často i mezi dospělými bývají proto neoblíbené. Všude se chovají stejně, nedokáží respektovat jakékoliv omezení. Bývají citově labilní, mají nízkou frustrační toleranci, na požadavky dospělých proto reagují nepřiměřeně, neočekávaně, často jsou agresivní.

Zároveň nedostatky $\mathrm{v}$ dovednostech mohou snižovat schopnost dítěte pozitivně reagovat na pokyny rodičů a pedagogů (uposlechnout, přizpo̊sobit se pokynům...) (Greene a kol. 2002, Pešatová 2003). Například dítě s omezením v oblasti pracovní paměti se může potýkat jak s vážnými potížemi a s chápáním následků předchozí neposlušnosti a neschopnosti se z ní poučit, tak i předpokládanými následky potenciálních činů ve formě problematického předvídání. Dítě se sníženou schopností kontrolovat své chování může reagovat na frustraci způsobenou požadavky na jeho poslušnost vysoce reakčně (např. křikem, pláčem, nadávkami), rovněž má nižší schopnost rychle vyhovět pokynům dospělého člověka. Děti s ADHD se svými obtížnými temperamentovými projevy mají často narušený vztah k jiným dětem a vzhledem ke zvýšené impulzivitě a nízké sociální akceptaci bývají z edukačního hlediska obtížně zvládnutelné (Pešatová 2013).

\section{Školní věk}

Citlivým indikátorem pro ADHD je škola a okamžitým diagnostikem učitel, nebot naprostá většina dětí s $\mathrm{ADHD}$ se potýká se zásadními problémy při plnění školních povinností a s nevhodným chováním (Pfiffner, Barkley 1990), které souvisí s nízkou mírou pozitivní komunikace s učitelem a vyšší mírou negativismu (Whalen, Henker 1999). Tyto vzorce chování přispívají k výrazně nedostatečným školním výkonům, umístění do speciálních vzdělávacích zařízení, opakování ročníku, indikaci individuálního vzdělávání atd. (Hinshaw, Melnick 1995 in Pešatová 2007, Pešatová 2013).

Nežádoucí chování u hyperkinetických poruch bývá často vyvoláno aktuálními situačními podněty, kdy se vůbec neuplatní rozumové hodnocení nevhodnosti či rizika takového chování. Impulzivitu lze 
chápat jako neschopnost selektivní regulace chování, aby odpovídalo požadavkům dané situace. Tyto děti mnohdy nejsou schopné odhadnout následky svého jednání. Často se tak spustí řetězec na sebe navazujících reakcí, které dítě dostává do pozice odmítaného a negativně hodnoceného jedince. Za těchto okolností se dále zvyšuje míra zatížení nepř́ijemnými podněty a s tím související riziko neadekvátního reagování (Vágnerová 2004).

Ve školním prostředí se žáci s ADHD velice těžko podřizují školním pravidlům. Neudrží pozornost na práci a často kazí aktivity ostatních dětí bez popisovaných problémů. $\mathrm{V}$ důsledku své impulzivity často reagují naprosto zkratkovitě a vrstevníci ani dospělí nejsou schopni př́liš jejich jednání porozumět (Michalová 2011). Reagují a chovají se na celkově nižší sociální úrovni než věkově stejně staré děti, což je důsledek jejich emoční nezralosti. Proto ve vrstevnických vztazích nemají lehkou situaci. Dostávají se do sporu s ostatními a mnohdy nepatří ani mezi nejoblíbenější. Není výjimkou, že se žák s touto poruchou stává obětí šikanování. Minimálně $25 \%$ dětí s ADHD zároveň trpí dyslexií, dysgrafií, dysortografií, dyspraxií. Přítomnost specifických poruch v tomto případě školní situaci ještě ztěžuje. Neúspěch ve výuce v kombinaci s menší oblibou mezi vrstevníky a učiteli způsobuje stav jejich nízkého sebevědomí a sebehodnocení. Nejsou-li tyto děti úspěšné a oblíbené, pokouší se velmi často kompenzovat svůj problém nevhodným upozorňováním na sebe a zlobením. Učitel ve škole i rodič doma musí volit individualizovaný přístup $\mathrm{k}$ dítěti a pomáhat mu překonávat náročné situace. Doporučuje se především trpělivost, časté povzbuzování a pochvala, vytvoření pohybu i v době výuky apod.

Dítě hyperaktivní a motoricky neklidné bývá často v sociálně složité situaci. Svým neklidem znemožňuje vytváření sociálních vztahů, zároveň svou hyperaktivitou rušivě zasahuje do vztahů již vytvořených (Břicháček 2003). Neschopnost začlenění se do dětského kolektivu a kooperace s ním včetně vysoké míry impulzivity často zpơsobuje, že děti s diagnózou hyperkinetické poruchy jsou kárány a odmítány všude - doma, ve škole, při sportu, hrách, a to jak v kolektivu dětí, tak i dospělých. Vzhledem k tomu, že nejsou schopny kontrolovat své 
reakce k okolí, nebývají empatické, altruistické, mají extrémní výkyvy jak emocí, tak chování.

Dlouhotrvající sociální frustrace pak negativně ovlivňuje sebehodnocení těchto dětí a může se stát spolufaktorem rozvoje problémového až poruchového chování (Pešatová 2013).

Ve věku 7-10 let se u 30-50 \% dětí s ADHD rozvíjí porucha chování nespecifická, nejčastěji opoziční vzdor, agresivita, lhaní, někdy i záškoláctví a krádeže. Zároveň se ale také objevují úzkostné poruchy a poruchy nálady čili poruchy adaptace.

\section{Období adolescence}

S příchodem adolescence se hyperaktivita zmírn̆uje. Právě klesající hyperaktivita $v$ tomto věku rozšírila mýtus o ústupu ADHD spolu s dospíváním.

Socializace ale probíhá v dospívání u jedinců s ADHD obyčejně nápadně, i když individuálním způsobem a různým tempem, v závislosti na somatických změnách, změnách osobnosti i na všech sociálních vlivech prostředí. Mezi hlavní vývojové úkoly adolescentního období patří zejména uvolnění z přílišné závislosti na rodičích a navazování diferencovanějších a významnějších vztahů $\mathrm{k}$ vrstevníkům obojího pohlaví. Proces emancipace může nastoupit teprve tehdy, jestliže jsou vztahy v rodině stabilní a dítě má zkušenost s trvalým a spolehlivým citovým zázemím. Č́m hlubší, jistější a méně konfliktní jsou vztahy, které dítě k rodičům navázalo, tím snáze tento proces osobního zrání probíhá.

Vztahy mezi rodiči na jedné straně a dětmi a dospívajícími s ADHD na straně druhé jsou často problémové a konfliktní (Pešatová 2013). Rodinný život se vyznačuje vzájemnými rozpory a hádkami. Studie dospívajících s ADHD a jejich rodičů potvrzují trvání vyšší míry negativního chování, konfliktů a méně pozitivního a vstř́ícného přístupu k sobě navzájem oproti ostatním dospívajícím a jejich rodinám (Edwards a kol. 2001). 
Osamostatňování v sobě nese základní konflikt, rozpor mezi potřebou emancipace, nezávislosti a potřebou stability, která představuje jistotu a bezpečí. Často zmiňovaným názorem je, že jedinec tohoto věkového období chce svobodu a privilegia dospělých s odpovědností, péčí a ochranou dítěte. Množství a variabilita vztahů k vrstevníkům se zvětšují. Jejich smyslem je poskytovat sociální ocenění a novou jistotu, kterou dospívající odpoutáním od rodiny částečně opouští.

Vztahy s vrstevníky mohou mít skupinový nebo párový charakter. Skupina je důležitým socializačním činitelem, významně ovlivňuje hodnocení, postoje a zájmy svých členů. Funguje zde identifikace a nápodoba, hodnocení skupiny se postupně stává důležitou součástí sebehodnocení jedince. Jedinec s ADHD nebývá připravený zvládnout zodpovědnost za své chování. Pokud rodiče veškerou odpovědnost přesunou pouze na své dospívající dítě, ve většině případi̊ tuto samostatnost a přemíru zodpovědnosti nezvládne.

Až $30 \%$ takovýchto dospívajících experimentuje s drogami, kouří, propadá hazardním hrám. Zhruba stejné procento jedinců s ADHD provozuje asociální a někdy i antisociální chování. V rodině dochází k defektním vztahům mezi dospívajícím a rodiči, prohlubuje se jejich vzájemné nepochopení až nesnášenlivost. Více než polovina dospívajících s ADHD opakuje ročník na střední škole nebo je dokonce vyloučena. Nejde jen o to, zda je dotyčný zvyklý být ve škole úspěšný, ale i o to, zda má vůbec nějaký důvod snažit se podávat dobrý výkon i do budoucna. Pokud dosahovaný úspěch nepředstavuje pro dotyčného žádnou hodnotu, či pokud by úspěchu chtěl dosáhnout, ovšem za podmínky velkých ústupků a překonávání složitých problémů, raději volí neprospěch.

Hyperaktivita bývá ve škole problémem hlavně u mladších dětí, ale nepozornost narušuje školní výkon mnohem více, a to v průběhu celého života. Impulzivita má zase negativní dopad především na mimoškolní aktivity a projeví se jako vyhledávání adrenalinových zážitků, experimenty s návykovými látkami, riskantním řízením motorových vozidel, rizikovým sexuálním chováním, verbální impulzivitou a reaktivní agresí. Objevuje se ještě další důležitý příznakový 
okruh, emoční dysregulace (viz níže) (Barkley 2009). Dospívající a dospělí si obvykle vytvoří různé kompenzační mechanismy, aby zmírnili deficity, které ADHD přináší. Některé z nich bývají funkční (např. vedení diáře, sport, meditační techniky), jiné dysfunkční (např. opakované odkládání nepříjemných úkolů - prokrastinace, samoléčení marihuanou, extrémní kư̌áctví aj.).

\subsection{Intervence, terapie a léčba}

ADHD je velmi častá porucha narušující především exekutivní funkce, která má genetický základ a je celoživotní. Příznaky se objevují v dětství (z definice před 7. rokem života) a přetrvávají do dospělosti. U menší části pacientů dochází $\mathrm{k}$ remisi v průběhu dospívání. ADHD výrazně narušuje kvalitu života od dětství až po dospělost (Theiner, 2012).

Lze předpokládat, že ADHD bude mít negativní dopady na vztahy dítěte s jeho vrstevníky a může způsobit následné potíže jedince s ADHD s přizpůsobivostí v době dospívání a dospělosti. Proto je třeba velmi zdůrazňovat význam úspěšné terapie (Barret, Ollendick 2007).

Terapie by proto měla zahrnovat nefarmakologické i farmakologické intervence. Z nefarmakologických intervencí je pro menší děti nejúčinnějším rodičovský trénink a případně nácviky sebeovládání (Barkley 2006). Důležitá je také informace pro školu a doporučení vhodného vzdělávacího programu. Existují i různé metody, které zlepšují kognitivní deficity za použití počítače. U adolescentů je pak vhodná důkladná edukace, poradenství pro rodiče, poradenství s plánováním času a strukturací denního programu, nácvik sebeovládání a pomoc při interpersonálních problémech.

Některé terapeutické programy usilují o to, aby se děti naučily samostatně rozpoznávat signály, že mají kognitivně „zabrzdit“ a nějakým způsobem prodloužit interval mezi podnětem a svou vlastní reakcí. V těchto programech terapeuti děti učí, aby samy sobě ve vhodné chvíli opakovaly určité pokyny - např. „Počkej! Podívej se! Zamysli se!“ Tyto sebeinstrukce slouží dítěti jako vodítko, aby se uchýlilo 
$\mathrm{k}$ naučené metodě řešení problému. U impulzivních dětí jsou vhodné různé typy sebeinstrukcí zaměřené:

- na určení problému - „Co tady vidím? Jakou práci ted’ ode mě očekávaji??",

- na určení vhodného postupu - „Musím si to ještě jednou pozorně pročíst.",

- na udržení soustředěné pozornosti - „Musím se soustředit, něco jsem přehlédla.",

- sebeocen̆ující výroky - „Tentokrát se mi to opravdu povedlo!“,

- výroky, které dítěti pomohou zvládnout chybu a neúspěch "Nepovedlo se mi to, ale zkusim to znovu, treba mi to půjde lépe." (Kendall 1993).

V terapii dětí s ADHD se také používá nácvik podle vzoru, při kterém terapeut předvádí určité jednání a dítě je postupně opakuje po něm. Nácvikový program zahrnuje nácvik řešení problémů, nácvik podle instrukcí, udělování podmíněných odměn, nácvik podle vzoru, hraní rolí a nácvik rozlišování pocitů vlastních i pocitů druhých. U impulzivních dětí byl prokázán pozitivní účinek při nácviku metodou „Zastav se a premýšlej, než něco uděláš.“ (Kendall 1993, Michalová, Pešatová 2012).

Ve farmakologické léčbě existuje několik možností. Prakticky využívané v ČR jsou dvě látky, a to stimulant methylfenidát (ve formě s rychlým uvolňováním, či ve formě s řízeným uvolňováním OROS) a nestimulační preparát atomoxetin, inhibitor zpětného vychytávání noradrenalinu. V ČR jsou běžně dostupné preparáty Ritalin ${ }^{\circledR}$ (methylfenidát s rychlým uvolňováním), Concerta ${ }^{\circledR}$ (methylfenidát OROS) a Strattera ${ }^{\circledR}$ (atomoxetin) (Theiner 2012).

Populační výzkumy ukázaly, že příznaky přetrvávají přes dospívání až do dospělosti u téměř $80 \%$ pacientů (Ramsay, Rostlin, 2008). Hyperaktivita se v dospívání značně zmírňuje, někdy však dochází k její internalizaci - trvalému subjektivnímu pocitu potřeby neustále něco dělat. Porucha pozornosti a narušení exekutivních funkcí přetrvává v prakticky nezměněné míře (Theiner 2012). 


\section{Komorbidita ADHD a specifických poruch učení}

V oblasti specifických poruch učení panuje značná terminologická nejednotnost. $\mathrm{V}$ české odborné literatư̌e se můžeme setkat s termíny specifické poruchy učení, specifické vývojové poruchy učení, poruchy učení, specifické vývojové poruchy školních dovedností, narušení grafické stránky řeči (Pokorná 2001; Šturma cit. dle Říčan, Krejčířová, et al. 2006; Vitásková 2005; Zelinková 2003). Všechny tyto termíny jsou nadřazeny jednotlivým typům specifických poruch učení. SPU v sobě dle názoru Vitáskové zahrnují jak vývojové (dyslexie, dysgrafie, dysortografie, dyskalkulie.), tak získané formy specifických poruch učení (alexie, agrafie, akalkulie, atd.) (Vitásková 2006). $\mathrm{S}$ tímto názorem nelze zcela souhlasit. Alexie, agrafie a další podobné poruchy označují prostřednictvím onoho „a“ na jejich počátku úplnou ztrátu již rozvinuté dovednosti.

Adjektivem specifické odborná literatura vysvětluje, že je nutné odlišit specifické poruchy učení od nespecifických (tzv. pseudo nebo nepravých poruch učení), které mohou být způsobeny např. nedostatečně podnětným sociálním prostředím či mentální retardací (Matějček 1993; Mertin, Kucharská 2007). Adjektivum vývojové vyjadřuje, že tyto poruchy se projeví vždy na určitém stupni vývoje jedince a mají kontinuální charakter, tedy během vývoje se jejich obraz mění (Matějček, Vágnerová 2006). Mezi SPU patří:

- dyslexie - specifická porucha postihující oblast čtení,

- dysgrafie - specifická porucha postihující oblast psaní,

- dysortografie - specifická porucha postihující oblast pravopisu,

- dyskalkulie - specifická porucha v oblasti počítání,

- dyspraxie - specifická porucha v oblasti praktických motorických činností,

- českým specifikem bývá dysmuzie a dyspinxie. 
Je tedy patrné, že v tradičním chápání SPU stále převládá jejich deficitní pojetí. Tomu většinou odpovídá také charakter péče o jedince s touto poruchou, která se zaměřuje především na přímé odstraňování předpokládané příčiny nacházející se v deficitních percepčně-kognitivních funkcích (Michalová, Pešatová, 2011, s. 18).

Terminologická nejednotnost však panuje také v zahraničí. Lze ji zdůvodnit různorodou symptomatikou uváděných poruch včetně rozličných koncepčních a teoretických východisek, z nichž jednotlivé skupiny odborníků dle svého zaměření vycházejí (Michalová, Pešatová, 2011).

V americké literatuře se užívá k označení specifických poruch učení pojem „learning disabilities“, překládá se obecně jako poruchy učení nevztahující se na děti mentálně retardované, zároveň se též objevuje i termín „dyslexia“ (Pokorná 2001, s. 53).

Ve Velké Británii převažuje užití termínu „specific learning difficulties“, ve Francii preferují užití klasického termínu „dyslexie“.

Německá odborná literatura pracuje stermíny Legasthenie a Kalkulasthenie. Často se setkáváme stermíny spezifische Entwicklungsstörungen, Spezielle Lernprobleme, Teilleiutungsschwachen (Bartoňová 2006). Od těchto pojmů je třeba odlišit termín Lernbehinderte, který se v Německu přibližně od 70. let minulého století pojí s problémy v učení u jedinců, kteří spadají na základě výše svých aktuálních rozumových schopností do tzv. hraničního pásma či dokonce do pásma lehké mentální retardace (Grohnfeldt 2004).

Z pohledu medicínského nelze opomenout termín specifické poruchy vývoje školních dovedností (F81), zakotvený v 10. revizi Mezinárodní klasifikace nemocí. Je součástí Poruch psychického vývoje F80-F89. Do této kategorie odborníci řadí specifickou poruchu čtení (F81.0), poměrně široce vymezenou a zahrnující i vývojovou dyslexii, specifickou poruchu hláskování (F81.1), poruchu aritmetických schopností (F81.2) a smíšenou poruchu školních schopností (F81.3). 
Kromě toho hovoří o jiných (F81.8) a nespecifikovaných (F81.9) vývojových poruchách školních dovedností (MKN-10 2014).

\subsection{Druhy specifických poruch učení}

\subsubsection{Dyslexie}

Dyslexie znamená specifickou neschopnost naučit se číst běžnými výukovými metodami. Aktuální výkon ve čtení bývá měřen standardizovanými čtenářskými texty v provedení Matějčka a jeho spolupracovníků. Hodnotí se rychlost čtení a jeho kvalitativní úroveň (chybovost, porozumění).

$\mathrm{S}$ věkem se výkon ve čtení mění $\mathrm{v}$ závislosti na inteligenční úrovni dotyčného, na jeho cvičenosti ve čtení, stimulaci oslabených oblastí, možnostech reedukace, zájmu a spolupráci rodičů při odstraňování obtíží, ale i v závislosti na podpoře dítěte ze strany pedagogů.

Za signifikantní se považuje v raném dětství dvouleté opoždění ve čtení, později, když se čtecí schopnosti téměř stabilizují, nemusí být již tak významné. Mírnější formy poruchy nebo ty, které jsou spojeny s vysokým IQ, nemusí být objeveny až do středního školního věku, či naopak objeveny jsou, ale rodiče si nepřejí, aby jejich dítě bylo za dyslektika označené. Právo rodičů rozhodovat o dítěti je třeba respektovat i v př́padě našeho přesvědčení, že se dítěti vlastně ubližuje, škodí. Na druhou stranu někteří rodiče znají své dítě velice dobře a jsou schopni citlivě vystihnout jeho problémy a pomoci mu důsledně s jejich řešením.

Samotného termínu dyslexie je v literatuře užíváno ve dvou významech:

a) V širším slova smyslu znamená označení celého komplexu specifických vývojových poruch učení, a to z důvodu jejich častého společného výskytu u jedince. Užívá se tedy jako pojem obecný. V současnosti se zavedl termín specifické poruchy učení (SPU). 
b) V užším slova smyslu odlišuje tento termín poruchu čtení od ostatních poruch psaní, pravopisu, počítání. Označuje tedy jeden z druhů SPU.

Také u nás hojně užívaný termín dyslektik označuje v širším slova smyslu jakéhokoliv žáka se specifickou poruchou jak čtení, tak psaní, pravopisu... S tímto označením se setkáme především v běžné praxi pro rychlé a snadné dorozumění mezi odborníky.

V souvislosti se současnými trendy speciální pedagogiky, zdůrazňujícími osobnost jedince s postižením, by bylo vhodnější upřednostňovat termín „žák se specifickou vývojovou poruchou učení“ obecně, v užším slova smyslu „žák s dyslexií“, „žák s dysortografií“ atd.

\section{Co patří mezi typické dyslektické chyby?}

- Obtížné rozlišování tvarů písmen,

- snížená schopnost spojovat psanou a zvukovou podobu hlásky,

- obtíže v rozlišování tvarově podobných písmen,

- nerozlišování hlásek zvukově si blízkých,

- obtíže v měkčení,

- nedodržování správného pořadí písmen ve slabice či slově - tzv. inverze,

- přídavky písmen, slabik do slov,

- vynechávání písmen, slabik ve slovech,

- domýšlení si koncovky slova dle správně přečteného jeho začátku,

- nedodržování délek samohlásek,

- neschopnost čtení s intonací,

- nesprávné čtení předložkových vazeb,

- nepochopení obsahu čteného textu,

- dvojí čtení - žák čte nejprve slovo, slabiku či jeho část šeptem pro sebe, pak teprve vyslovuje nahlas. 


\subsubsection{Dysortografie}

Dysortografie je specifická porucha pravopisu, velice často se vyskytuje ve spojení s dyslexií.

J. Swierkoszová uvádí, že se s dysortografií často setkává u žáků s napravenou dyslexií, kteří i na druhém stupni ZŠ mají problémy v oblasti pravopisu (Swierkoszová in Lechta, et al. 1990).

Navenek se tedy projevuje u žáků narušenou schopností osvojovat si pravopis jazyka, a to i přes přiměřenou inteligenci a běžné výukové vedení, kterého se jim dostává. Typická je např. neschopnost dodržet pořadí písmen při psaní ve slově, nedostatky v měkčení, v nesprávném dodržování délek samohlásek, neschopnost aplikovat i dobře naučená gramatická pravidla do písemné podoby, chybí cit pro jazyk, jehož důsledkem je snížená schopnost např. skloňování a časování příslušných druhů slov. V žádném případě, jak vyplývá z výše uvedeného, porucha nepostihuje celou oblast gramatiky. Dotýká se pouze tzv. specifických dysortografických projevů. Podkladem často bývá nedostatečně rozvinutá oblast sluchové percepce (sluchová pamět, analýza, syntéza, audiomotorická koordinace, příp. i fonematický sluch). Nesmíme však zapomenout, že obtíže mohou vyplývat také z dysfunkce pravé mozkové hemisféry, přičemž se promítají u některých dětí i na druhém stupni ZŠ do záměny tvarově podobných písmen. Dysortografie se také může rozvinout na bázi poruchy dynamiky duševních procesů - na podkladě hyperaktivity, případně hypoaktivity, je negativně ovlivněn průběh procesu psaní. Žák se snadno unaví a není schopen správně aplikovat třeba i dobře naučené gramatické učivo do písemné podoby.

Shrňme problematiku dysortografie uvedením typických znaků dle Žlaba (1982). Ten rozlišuje dysortografii:

a) Auditivní, při níž jde o primární narušení procesů sluchové diferenciace a analýzy a oslabení bezprostřední auditivní (sluchové) paměti; žáci mají problémy v zachycení pořadí jednotlivých hlásek ve slově, smysl slova však chápou. 
b) Vizuální, při níž je snížena kvalita vizuální (zrakové) paměti. Jedinec není schopen si dokonale vybavit písmena (grafémy), tvarově i sluchově podobná. Žák není schopen napsané chyby v textu správně identifikovat a i při poskytnutí možnosti delšího času na opravu jich zvládá zachytit a opravit pouze velmi sporadické množství, ba dokonce někdy i chyby přidělá tam, kde původní pravidlo aplikoval správně.

c) Motorickou, která souvisí s namáhavostí a pomalostí vlastního aktu psaní. Př́ćinou je narušení jemné motoriky ve smyslu vývojové dyspraxie. Vlastní grafický projev odčerpává veškerou koncentraci pozornosti žáka, nedostává se jí již na uvědomělé aplikování gramatických pravidel a vlastní kontrolu napsaného cvičení.

Závěrem je nutné si dále uvědomit, že s věkem dítěte se mění obraz poruchy v jeho výkonnosti. Zhruba do třetí třídy se objevují klasické dysortografické chyby včetně záměn tvarů písmen, inverzí, různých zkomolenin slov. Postupně je těchto chyb méně, ovšem dítě i ve vyšší třídě potřebuje na správné napsání více času než žák bez poruchy. Pokud je vyvíjen tlak na zvýšení rychlosti při písemném projevu, je typickým jevem, že se i u staršího žáka dysortografické chyby znovu objeví, přibudou, a to obzvláště u dětí s dysgrafií. To vše navzdory tomu, že tyto jevy dítě bezpečně ústně ovládá.

Proto všichni odborníci doporučují poskytovat žákovi s dysortografií větší časový prostor pro vypracování písemností, nestresovat ho časovými limity a upřednostňovat u něj ústní zkoušení před písemným.

Co patři mezi specifické chyby dysortografického charakteru?

- Grafické záměny zvukově podobných hlásek (b-d, z-s, h-ch),

- obtížná výbavnost naučeného tvaru písmene v písemné podobě, snížená schopnost spojení,

- psané a slyšené podoby hlásky,

- záměny tvarově podobných písmen v písemné podobě,

- chyby z artikulační neobratnosti, 
- chyby v měkčení na akustickém podkladě,

- chyby v důsledku sykavkových asimilací,

- neschopnost dodržovat pořadí písmen, slabik ve slově, inverze,

- přidávání nepatřících písmen a slabik do slov,

- neschopnost dodržování délek samohlásek,

- neschopnost rozlišovat hranice slov ve větě,

- problémy ve slabikách a slovech se slabikotvorným $r, 1$.

\subsubsection{Dysgrafie}

Dysgrafie je specifickou poruchou psaní, čili grafického projevu jako takového. Spočívá v neschopnosti napodobit a zapamatovat si tvary písmen, psát čitelně, stejnosměrně, úhledně.

Samotný proces psaní vyčerpává dysgrafikovu kapacitu koncentrace pozornosti tak, že již není schopen se plně soustředit na obsahovou a gramatickou stránku projevu. Převaha obtíží spočívá v narušení úrovně jemné motoriky.

Písmo těchto dětí bývá neupravené, kostrbaté, hưře čitelné až nečitelné, nepamatují si dlouho tvary písmen, zaměňují je. Vlastní proces psaní je neúnosně pomalý vzhledem $\mathrm{k}$ fyzickému věku dítěte, neobratný, těžkopádný.

\section{Příklady specifických chyb při psaní:}

- Psaní jedince vyčerpává, energie nezbývá na jiné činnosti se psaním spojené (např. sledování správné aplikace gramatických pravidel),

- celkově nevzhledná úprava, často včetně ohnutých krajů listů v sešitě,

- neúměrně pomalé tempo psaní neodpovídající fyzickému věku jedince,

- obtížné zapamatování tvarů písmen či jejich nápodoby, a to i ve vyšších ročnících,

- nestejná velikost písmen, nestejnosměrný sklon, nedodržování a kostrbatost linie, 
- psaní za okraj, nad linku či pod linku sešitu,

- přepisování, obtížné spojování tvarů písmen,

- často preference psát velkým tiskacím písmem namísto psacím,

- záměna tvarově podobných písmen (tiskacích, psacích).

\subsubsection{Dyskalkulie}

Dyskalkulie je specifickou poruchou matematických schopností ve smyslu neschopnosti operovat s číselnými symboly. Podle Košče (1987) jde o strukturální poruchu matematických schopností, která má svi̊j původ v genově nebo perinatálními noxami podmíněném narušení těch partií mozku, které souvisí s přiměřeným anatomicko-fyziologickým zráním matematických funkcí; nemá však za následek poruchu mentálních funkcí.

Příznaky dyskalkulie jsou velice pestré, podle nich dělíme dyskalkulii do dalších typů.

\section{Typy dyskalkulie:}

1. Praktognostická - žák má narušenu matematickou schopnost manipulace s předměty konkrétními či nakreslenými a jejich přiřazování k symbolu čísla (paralelní přiřazování čísla k počtu a naopak, přidávání, ubírání, sestavování, odpočítávání na počítadle apod.). Postižena může být i schopnost řadit předměty podle velikosti nebo rozpoznávat vztahy v dimenzi více - méně.

2. Verbální - u žáka vázne schopnost slovně označovat operační znaky, vázne pochopení matematické terminologie ve smyslu určování o... více, o... méně, krát... více, méně, nezvládá slovně označovat matematické úkony, množství a počet prvků nebo i jen odpočítávat číselnou řadu; na slovní výzvu není žák schopen ukázat počet prstů, označit hodnotu napsaného čísla apod.

3. Lexická - typická je pro žáka neschopnost číst matematické znaky a jejich kombinace, symboly, jako jsou číslice, vícemístná 
čísla s nulami, hlavně uprostřed, tvarově podobná čísla apod. Jedná se o obdobu dyslexie v oblasti čtení číslic a čísel.

4. Grafická - projevuje se narušenou schopností psát numerické znaky, žák se neumí vyrovnat s příslušným grafickým prostorem, mívá problémy v geometrii. Jedná se o obdobu dysgrafie, ovšem v oblasti matematiky.

5. Operacionální - žák nezvládá provádění matematických operací - operace zaměňuje, nahrazuje složitější operace jednoduššími, písemně řeší i velice lehké úkoly.

6. Ideognostická - jedná se o poruchu v chápání matematických pojmů a vztahů mezi nimi, v chápání čísla jako pojmu, jedinec nedovede zpaměti vypočítat prríklady, které by vzhledem ke své inteligenci a dosaženému fyzickému i mentálnímu věku měl zvládnout zcela bez obtíží.

\subsubsection{Př́ibuzné poruchy}

Mezi tzv. příbuzné poruchy řadíme:

Dyspinxii - specifickou poruchu kreslení, je charakteristická nízkou úrovní kresby, neschopností zobrazit určité předměty a jevy adekvátně v závislosti na věku.

\section{Druhy a projevy dyspinxie}

1. Motorická - typickým příznakem je přerušovaná kostrbatá čára, roztřesené linie, přetahování nebo nedotahování linií, motorické zjednodušení tvarů. Čára bývá vedena křečovitě, s viditelným přítlakem, prorytím papíru, nebo naopak je slabá, přerušovaná.

2. Vizuální - zde chybí schopnost vytvořit vlastní představu, s níž je úzce spojena vizuální percepce a vizuální pamět. Jedinec nedokáže napodobit různé seskupení čar a obrazců, nedokáže zachytit prostorovou trojrozměrnost. V kresbě chybí detail, výtvor celkově působí schematicky. 
3. Integrační - zde se kombinují příznaky dyspinxie jak motorické, tak vizuální.

Dysmuzii - specifickou poruchu hudebních schopností, jedná se o narušení schopnosti vnímání a reprodukce hudby a rytmu. Relativně patří mezi častější specifické poruchy, nemá ale tak závažný dopad na výuku jako dyslexie, dysgrafie, dysortografie a dyskalkulie. Novotná a Kremličková (1997) dělí dysmuzii na expresivní, jež neumožňuje dítěti reprodukovat třeba i velice známý hudební motiv, který dokáže běžně identifikovat, a totální, což je nedostatek hudebního smyslu vůbec. V tomto druhém případě jedinec hudbu nechápe, neidentifikuje ji, nepamatuje si ji.

Dyspraxii - porucha motorické obratnosti v různých oblastech; podílí se na utváření celkové pohybové charakteristiky chování. Dle Říčana a Krejčířové (2006) prríčinu není možné hledat pouze v oblasti motorické, ale také v oblasti procesů poznávacích. Jako diagnostická kategorie se příliš často neobjevuje. Jedinci s dyspraxií téměř vždy trpí nízkým sebehodnocením.

\section{Typické v přístupu k těmto dětem bývá:}

- snížení známky z tělesné výchovy, výtvarné výchovy, pracovního vyučování,

- posměch učitelů, především učitelů tělesné výchovy (nebývají ochotni uznat, že jde u dětí o poruchu, nikoliv o lenost, nedostatek snahy, důsledek bázně z určitého úkonu),

- nezvládají dokonale sebeobsluhu, a to od raného dětského věku až do dospělosti,

- jsou pomalí,

- mají omezený výběr aktivit při zájmové činnosti,

- trpí pocity méněcennosti,

- v dospělosti častěji trpí pocity deprese a anxiety.

Typické obtíže jedinců s dyspraxií:

- špatný odhad vzdálenosti, 
- neschopnost provádět více aktivit současně (pohybová aktivita spojená se slovní objasňující instrukcí...),

- neodliší podstatné úkoly od nepodstatných,

- neumí se poučit z chyb,

- obtíže s udržením očního kontaktu při komunikaci,

- problematická tzv. organizace sebe sama (př. starší žáci nosí stále při sobě všechny učebnice, nebo naopak žádné, neumí si sestavit smysluplný rozvrh, připravit postup řešení problému, úkolu).

Žáky s dyspraxií je třeba při plnění úkolů povzbuzovat. Chválíme citlivě, velice dobře si uvědomují své obtíže, často i v pochvale hledají „postranní úmysly“ a invektivy dospělého.

\section{Plán řešení úkolů}

1. rozhodni, co bys chtěl udělat,

2. rozhodni, co udělat musíš, ačkoliv se ti do toho nechce,

3. urči pro tebe nejdůležitější úkol ze všech, mluv o něm,

4. zapiš si nejdůležitější kroky pro jeho řešení,

5. napiš aktivity, které zvládneš snadno a které se týkají řešení daného úkolu,

6. napiš aktivity, kterých se obáváš,

7. pomáhej si vizualizací,

8. ř́íkej, co právě děláš a proč,

9. napiš si seznam úkolů, které musíš udělat a postupně je odškrtávej (Michalová, Pešatová 2011, s. 28-35). 


\subsubsection{Specifické vývojové poruchy učení v MKN-10}

Specifickými poruchami učení se zabývá též 10. revize Mezinárodní klasifikace nemocí ve svém oddíle Duševní poruchy a poruchy chování. Najdeme je v kategoriích F80-F89 Poruchy psychického vývoje. Vzhledem $\mathrm{k}$ důležitosti a nutnosti pracovat $\mathrm{s}$ dítětem se SPU týmově (učitel, sociální pracovník, speciální pedagog, psycholog, neurolog, dětský psychiatr...) je vhodné vyznat se v následujících diagnózách uvedených v tabulce 3.

Tabulka 3: Duševní poruchy a poruchy chování dle MKN-10 (2014)

\begin{tabular}{|l|l|}
\hline F80 & Specifické vývojové poruchy řeči a jazyka. \\
\hline F81 & Specifické vývojové poruchy školních dovedností. \\
\hline F81.0 & Specifická porucha čtení. \\
\hline F81.1 & Specifická porucha psaní. \\
\hline F81.2 & Specifická porucha počítání. \\
\hline F81.3 & Smíšená porucha školních dovedností. \\
\hline F81.8 & Jiné vývojové poruchy školních dovedností. \\
\hline F81.9 & Vývojová porucha školních dovedností nespecifikovaná. \\
\hline F82 & Specifická vývojová porucha motorických funkcí. \\
\hline F83 & Smišené specifické vývojové poruchy. \\
\hline
\end{tabular}




\section{Etické zásady sdělování diagnózy a proces jejího přijetí rodiči}

Citlivé a promyšlené sdělení diagnózy rodičům či přímo klientovi je klíčovým startovacím stimulem celého dalšího vzdělávacího procesu. Speciální pedagog musí mít neustále na paměti, že se jeho klienti mohou nacházet $v$ mezní životní situaci, kdy jsou mimořádně citliví na přijetí jakéhokoliv sdělení. Velmi často zpravidla ke speciálnímu pedagogovi přicházejí už po určité znalosti diagnózy lékařské či psychologické, ale právě díky specifickým reakcím na traumatizující zprávy se může stát, že se speciální pedagog stane prakticky prvním, od koho svou životní prognózu uslyší a budou schopni ji zcela vnímat.

Sdělení diagnózy sice podléhá určitým pravidlům a řídí se znalostmi jednotlivých fází přijetí diagnózy, přesto je vysoce individuální záležitostí. Především se musíme vyvarovat chyb, které by mohly vést $\mathrm{k}$ tomu, že se diagnóza stane pro klienta či jeho rodiče rozsudkem nebo alibi.

Diagnózu musí speciální pedagog sdělovat promyšleně, citlivě a ohleduplně. Sdělování informací musí splňovat některé zásady: Musí být pravdivé, nijak zkreslené, musí odpovídat realitě, nesmí poskytnout falešné a nereálné naděje anemělo by být ani přehnaně pesimistické.

Diagnóza slouží jako důležitá startovací čára pro další život klienta i jeho rodiny. Proto:

- Diagnóza se v žádném př́ípadě nesmí stát důvodem k odsouzení klienta, nesmí být podnětem k trestu.

- Diagnóza a další zpo̊sob zacházení s ní musí respektovat svobodu klienta - nesmí vyústit k nucenému rozhodnutí. Klient se vždy rozhoduje sám a svobodně, speciální pedagog ho pouze směruje a nabízí různé alternativní způsoby řešení. 
- Speciální pedagog musí klienta respektovat - musí mít pocit akceptace ze strany poradce, může zamítnout i odsoudit klientovo chování - nesmí však odsoudit jeho samotného, nesmí ho zbavit důstojnosti a musí akceptovat jeho reakce.

- Speciální pedagog by měl navodit spolupráci nejen s klientem a jeho rodinou, ale is dalšími participujícími institucemi, školou, vrstevníky...

- Speciální pedagog sděluje klientovi pravdu s perspektivou nabízí mu perspektivu do budoucna.

- Speciální pedagog se snaží nalézt jakákoli pozitiva a důvody pro naději a optimismus.

- Interpretace stavu musí být podložena exaktními poznatky, závěry podložené, nejlépe z několika zdrojů, se musí opírat o co nejpřesnější a vyčerpávající informace. V případě nejistoty je třeba konzultovat s odborníky, klientovi nesdělujeme jako fakt něco, co důkladně neznáme, nevíme; nepřekračujeme tím své kompetence.

- Speciální pedagog respektuje důvěrný ráz informací a dat, s nimiž pracuje, prokazuje takt klientovi.

- Sděluje-li speciální pedagog diagnózu či jiné doporučení o dětském klientovi, ideální situací bývá přítomnost obou rodičů či blízké osoby, aby mohli přijatou i nepř́ijemnou informaci společně sdílet. Rodiče potřebují dostatek prostoru i času ke zpracování takové informace.

Speciální pedagog by také měl být připraven na to, že reakce rodičů či plnoletého člověka po sdělení diagnózy probíhají v určitých za sebou následujících fázích. Jejich průběh, délku a intenzitu může ovlivnit zpơsob sdělení diagnózy, osobnostní vlastnosti rodičů, jejich předchozí zážitky, stupeň postižení dítěte, převažující postoje společnosti, v které žijí.

1. Fáze - šok. Typicky se objevuje duševní otřes provázený úzkostí, zmateností. Klient není schopen situaci uvěřit, rodiči se hroutí ideál vysněného zdravého dítěte, na který byl 
nasměrován. Dostává se do subjektivně nepřijatelné situace, lze očekávat př́ípadné iracionální jednání. Prochází citovou zmateností, dezorientací, dochází k ochromenému jednání i myšlení. Tato etapa může trvat různě dlouho, od několika hodin až týdnů, ale i déle. $\mathrm{V}$ této fázi bývá negativně ovlivněno vnímání, je možné, že je třeba diagnózu opakovaně vysvětlit, protože si klient sdělení nepamatuje.

2. Fáze - reakce. V této fázi se spolu často kloubí beznaděj a obranná reakce. Klient (rodič) si plně uvědomí skutečnost, ale ještě není schopen hledat východisko, nebot jej ochromují žal, beznaděj, zoufalství, zklamání. Tato situace opět trvá různě dlouho, třeba i několik měsíců. V případě dětského klienta u každého z rodičů může probíhat různě dlouho a stává se uvnitř rodiny zdrojem dalších konfliktů a nedorozumění. Úlohou nastupující vnitřní obrany bývá popření skutečnosti, následuje touha po nápravě, která může vést k vyhledávání neexistujících řešení, léků, operací. V této fázi mohou lidé dlouhou dobu vynakládat mnoho úsilí zaměřeného špatným směrem, kdy se zaměřují na odhalení diagnostických chyb, vyžadují opakovaná vyšetření. Mnoho energie jim odčerpá hledání viníka, nesmyslná, nepravdivá a nepodložená obviňování druhých směřujících v jejich představách ke skutečnému odhalení, kdo za to tzv. může. Velkou pomoc v této fázi pro rodiče představuje zprostředkování kontaktu s podobně postiženými rodiči, lidmi. Je to období plné rozporů, vzniku případných depresí a konfliktů, často končících rozpadem rodiny, kdy nejčastěji odchází otec.

3. Fáze - adaptace. Obvykle dospěje do tohoto stádia první matka dítěte, někteří rodiče do něj ovšem nedospějí nikdy. Teprve $v$ této fázi se klient pokouší o racionální řešení situace. Důležitý je opět správný přístup poradce, od kterého se předpokládá, že bude schopen klientům dát optimistickou perspektivu, ale nebude v nich vzbuzovat nereálné naděje. 
Rodiče začínají jednat, vyhledají pomoc SPC - zajímají se o to, co mohou udělat, přizpůsobí se dané situaci a potřebám dítěte. Často musí změnit zaměstnání, přestěhovat se za službami potřebnými pro prosperitu jejich dítěte, apod.

4. Fáze - reorientace - rodič přijímá dítě takové, jaké je. Život dostává nový smysl pro celou rodinu, plánuje se budoucnost dítěte.

Někteří rodiče závažnou skutečnost nepřijmou nikdy a nejsou schopni dítě akceptovat takové, jaké je. Mnohé rodiny se rozpadnou či dítě umístí do ústavní péče. Mnozí se opakovaně vrací do předchozích fází, a to především tehdy, když narazí na nové překážky - například při umístování dětí do systému vzdělávání, při zjištění, že dítě nebude nikdy pracovat, nebude soběstačné apod. 


\section{Zásady intervence $u$ jedinců s ADHD}

Při edukaci dětí s ADHD je vhodné postupovat po malých krocích. Jedinci s touto poruchou mívají typicky omezenou schopnost autoregulace způsobenou nedostatečnou vnitřní kontrolou. Bude-li k nim přistupováno s mírou hostility, nezájmu, nebudou-li se učit dosahovat přiměřených cílů za využití vlastních schopností, většinou se dostanou do stádia rezignace. Reagují tzv. naučenou bezmocností (Helus 2004; Vágnerová 2008). Těžiště kontroly (locus of control) se oslabuje, žáci přestávají věřit, že zažívané situace mohou svými vlastními silami nějak ovlivnit. Znamená to tedy, že adekvátním individuálním přístupem zaměřeným na posílení důvěry žáka ve své vlastní schopnosti lze předejít afektivnímu chování v situaci neúspěchu a docílit lepšího zvládání tzv. stresových situací ve školním prostředí. Vnímaná kontrola tedy široce variuje od bezmocnosti po vysokou kontrolu, její míra je závislá na zdraví konkrétního dítěte, na vnějších podmínkách (pokud je žák schopen vysoce kontrolovat vnější podmínky, je jeho vnímaná kontrola vysoká, a naopak).

\section{Obecně je nezbytné:}

- poskytovat dítěti bezprostředně zpětnou vazbu,

- co nejčastěji dítě pozitivně hodnotit, a to i za pouhou snahu,

- používat názorná a jasně srozumitelná ocenění,

- preferovat pochvaly místo trestu,

- „zviditelnit“ čas pro dítě (aby dítě při práci vidělo na hodiny, upozorňovat na časový limit),

- důležité informace zviditelnit (např. kartičky s důležitými pravidly na stole), dítě si tak stále tyto informace připomíná,

- zviditelnit problém (poukázat na problém a jeho řešení - například pomocí kartiček),

- nerozčilovat se, ale jednat (napomínání dítě vnímá, ale obsah přednášky mu uniká), 
- snažit se o uplatnění stejných strategií ve školním i v domácím prostředí,

- předvídat problémové situace (aktivity plánovat tak, aby se dítě co nejméně nudilo, sdělovat méně pravidel najednou - jejich dodržování komentovat, chválit, odměňovat),

- problémy dítěte nepovažovat za svůj osobní problém,

- smírit se s tím, co už se stalo a plánovat změny,

- myslet na budoucnost, zachovat si odstup od problémů (Goetz, Uhlíková 2009).

Zelinková (2003) uvádí následující postupy reedukace vhodné pro žáky s ADHD:

- Pozitivní posilování - musí následovat ihned po splnění úkolu. Vede k uspokojení dítěte a snaze znovu získat pochvalu.

- Častá zpětná vazba - pochvala a pozitivní hodnocení působí jako zpevnění žádoucího chování. Odměna musí být pro dítě smysluplná.

- Instrukce a pokyny smí obsahovat jen několik kroků. Nezbytné je ujištění, že žák instrukci rozuměl. Dodáváme, že je třeba nechat dítě vlastními slovy zopakovat podstatu zadané práce.

- Důležitější je kvalitní plnění a dokončování úloh než postup, jakým se dítě k výsledku dostane.

- Úlohy musí být smysluplné, přiměřeně obtížné, splnitelné, krátké.

- Jednoznačná pravidla chování přispívají k pocitu bezpečí, vytvoření systému a řádu.

- Optimismus, pravidelný režim a systematičnost.

- Spolužákům je třeba vysvětlit přiměřenou formou podstatu obtíží.

- Předcházíme izolaci žáka, zapojujeme ho do všech aktivit ve třídě.

- Vhodné je poskytnout podmínky pro změnu činností, polohy při učení. 
- Nácvik metakognitivních strategií zaměřených na řízení sebe samého, pozorování svých pracovních postupů, sebehodnocení.

- Učitel by měl respektovat individuální učební styl žáka. Pro dítě s ADHD je typický globální styl učení, tj. přednostní vnímání celků.

- Sebekontrola a sebehodnocení vede $\mathrm{k}$ uvědomění si vlastního chování.

Na základě našich poznatků ještě dodáváme, že velký význam má poskytování prodlouženého času na práci s přitahováním pozornosti k jejímu zpracování. Také přiměřené povzbuzování vede $\mathrm{k}$ optimistickému pohledu na dění kolem sebe. Snižuje se jím strach $\mathrm{z}$ neúspěchu, dítě se tolik neobává podstoupit i určité riziko při řešení problému, což ústí v prožitek úspěchu a nabytí sebedůvěry vedoucí $\mathrm{k}$ očekávání dalších úspěchů. Při výrazném pesimistickém ladění se doporučuje redukovat ony explanace jedince prostřednictvím souboru technik kognitivně-behaviorální terapie a rozvojem sociálních dovedností. Ty by měly, jak říkají Carver se Scheierem, „redukovat automatické negativní myšlenky (a jiné projevy) a jádrová přesvědčení skrytá za nimi“ (Carver, Scheier 2002, s. 240).

V rámci intervenčních strategií by nemělo chybět ani posilování volních vlastností žáků (zvyšování houževnatosti) a zařazování humoru do výuky.

\section{Posilování volních vlastností}

„Houževnatost kladně koreluje s vysokou výkonovou úrovní jedince $v$ zátěžových situacích, zvýšenou schopností se učit, emočni stabilitou, rezistencí vůči depresi (a naučené bezmocnosti) a fyzickým zdravím" (Dienstbier, Zillig 2002, s. 518). U dětí/žáků s ADHD lze houževnatost stimulovat prostřednictvím her a alespoň občasnou změnou vážné výuky v zábavnou činnost.

Ale pozor, i zvyšování houževnatosti má své hranice. Labilitu a rezignaci vyvolávají nepředvídatelné a vysoce náročné podněty (Rodriguez, et al. 1998), náročný trénink bez možností regenerace sil 
(např. Morgan, et al. 1987), jednorázové traumatické události a obecně podmínky vedoucí $k$ posttraumatické stresové poruše (Barlow, et al. in Hope 1996, s. 269). Nadměrná zátěž u dětí s ADHD a se SPU ústí do podoby neuróz a somatizace. Nejčastěji mívají sníženou chut k jídlu, pocity nevolnosti, časté bolesti hlavy, poruchy spánku, tikové neurózy (Pešová, Šamalík 2006).

\section{Humor}

Dobrácký humor je nositelem pozitivního sociálního klimatu ve třídě, podporuje kreativitu nejen žáků, ale i učitelů. Ovlivní reálnou školní úspěšnost či neúspěšnost jedince (Čáp, Mareš 2001; Kher, Molstadt, Donahue 2008), souvisí i s vnitřním uspokojením pedagoga s vykonávanou profesí. Pedagogové, kteří umí vhodně humor ve vyučovacích hodinách používat a akceptují i laskavý humor svých žáků, nemívají problémy s kázní a s vlastní autoritou (Sedlák 2006). Platí tedy mnohokrát ověřená skutečnost, že úspěšnost učitele nesouvisí pouze s tím, jak dobře a efektivně vyučuje svěrené žáky, ale především s tím, jaký s nimi naváže vztah a způsob komunikace, v níž i pozitivní humor má své místo.

Pro žáky s problémy ve výuce platí uvedené tvrzení ještě mnohem více než pro žáky bez obtíží. Za pozitivní humor posilující třídní atmosféru rozhodně nelze považovat škodolibé rádoby humorné upozorňování na nedostatky žáků v jejich dovednostech a schopnostech, vzhledu apod. S tím se lze bohužel ve školním prostředí setkat, často i ze strany učitele (Sedlák 2006), a to nejen směrem k žákovi se SVP. Učitel nezvládne pedagogickou situaci a svou rozladu vůči dotyčnému ventiluje popisovaným zpo̊sobem. Takový a obzvláště dlouhodobý přístup může vývoj žáka narušit a negativně ovlivnit formování jeho osobnosti (Čáp, Mareš 2001). Naopak dobře použitým humorem ze strany učitele lze při jednání se zákonnými zástupci žáka probrat i nepř́ijemná komunikační témata. Rodiče se ve většině případů snaží své dítě obhajovat a komunikační styl zvolený učitelem může ovlivnit, zda se budou cítit ve svých kompetencích ohroženi, či nikoliv (Knopf, Swick 2007). 
Lefcourt mj. doporučuje u jedinců v jakémkoli věku, kterým povahový rys humoru chybí, aby se učili snižovat strach z vlastního zesměšnění. Měli by prožít pocit, kdy se jim podaří rozesmát ostatní či učit se ocenit dobrý humor. Jedná se bezesporu o jeden z možných námětů, jak pracovat s žáky a učiteli, kteří příliš humor nechápou či je zúzkostňuje (Lefcourt 2002).

Problémem je často i snížený zájem učitele o méně nadané či jinak problémové děti, kritické poznámky na jejich osobu, přehlížení toho, co se jim povedlo, alergické reakce na prohřešky proti kázni nebo na neznalost učiva. Učitel by neměl v žádném případě tolerovat sebemenší náznaky ubližování a šikany (Michalová 2007; Riefová 2010). Je tedy nutné, aby učitelé byli informováni o obtížích žáka, o správném postoji k jeho problémům a způsobech reedukace. Učitelé by měli nejprve dobře porozumět tomu, jaké kognitivní a afektivní problémy porucha způsobuje. Teprve potom mohou erudovaně vytvářet postupy, jež dětem s ADHD pomohou dosahovat náležitých úspěchů ve škole i v osobním životě. V procesu je důležité využít vlastní aktivitu jedince s ADHD, nebot̉ právě ta je nezbytnou součástí dosaženého úspěchu ve vzdělání, ale ivcelém dalším zapojení do společenského života každého jednotlivce (Asherson, a kol. 2005; Michalová 2007; Riefová 2010).

Naprostou nezbytností úspěšné a efektivní práce s žákem s ADHD je rovněž navázání dobrého vztahu a spolupráce s rodinou žáka. Učitel by měl s rodinou neustále komunikovat, vysvětlovat, navrhovat řešení potíží, konzultovat s rodiči.

Dalším faktorem ovlivňujícím vzdělávání dětí s ADHD je i jeho ekonomická náročnost. Upozorňují na ni Munden s Arcelusem (2008). Protože vzdělávací systém nemá dostatek zdrojů, dostává se dostatečné pomoci pouze dětem, které jsou na tom velmi špatně. Uvádí to výzkum, který prokazuje, že 40 \% dětí ze základních škol vyřazených z běžné výuky splňovalo klinická kritéria hyperaktivity, $\mathrm{z}$ čehož plyne, že tyto děti trpěly ADHD. Ačkoli byly docela jistě shledány dětmi „problémovými“, příčina, která leží v pozadí jejich obtíží, zůstala bez povšimnutí a dětem se v první řadě nedostalo 
pomoci, která by bývala krizi zabránila. Tento stav může být částečně i důsledkem nevědomosti a nedostatečného odborného vzdělání. Mnozí učitelé problémy vidí, dokáží je popsat, ovšem často si neuvědomí, že jejich př́ičinou bude ADHD.

Každý učitel by si měl být především vědom, že v náročné práci $\mathrm{s}$ dětmi s ADHD má v tuto chvíli výborného pomocníka zabudovaného do Rámcového vzdělávacího programu a je v kompetenci každé školy, jak jej dokáže ve svůj prospěch využít. Je jím Osobnostní a sociální výchova (dále jen OSV), synonymum komplexního rozvoje osobnosti, chápeme ji jako cestu osobnostního růstu zejména pro žáky s ADHD. Vychází z termínu užitého londýnským učitelem Birchem „Personal and Social Education“. Na přelomu 80. a 90. let 20. stol. v naší republice tento termín přeložili brněnští divadelní pedagogové spolu s návrhem osnovy jeho výuky jako samostatného předmětu. Od 90. let 20. století po vydefinování obsahových rozdílů mezi osobnostní a sociální výchovou a dramatickou výchovou se v České republice OSV zvolna rozvinula v samostatnou oblast výchovy.

V podobě průřezového tématu Rámcového vzdělávacího programu by měla bezprostředně prolínat nejen všemi vyučovacími předměty, ale především by měla být nedílnou součástí formování školního klimatu. Svým obsahem zcela logicky prolíná vztahy mezi žáky, mezi učiteli a žáky navzájem, je všudypřítomná ve vztahu pedagogů $\mathrm{k}$ sobě navzájem i ve vztahu pedagogů, rodičů a žáků. Vytváří tzv. školní atmosféru.

Považujeme ji za praktickou disciplínu, která se zaměřuje na rozvoj klíčových dovedností a kompetencí nezbytně uplatnitelných v reálném životě.

Jde zejména o kompetence, resp. dovednosti:

- osobnostní,

- sociální,

- morální. 
Spočívá nejen v doplňování dovedností již získaných, ale i v jejich přetváření nebo v osvojování dovedností zcela nových. Tyto procesy probíhají jak nevědomě, tj. zcela náhodně, tak $\mathrm{z}$ druhé strany záměrně, cíleně, což je samozřejmě mnohem efektivnější a rychlejší způsob jejich získání či přetvoření (Michalová, Pešatová 2012).

Výuka průřezového tématu Osobnostní a sociální výchova vychází $\mathrm{v}$ podstatě $\mathrm{z}$ teoretického činnostního přístupu kombinovaného s přístupem sociálně-kognitivním integrujícím myšlenky kognitivní psychologie, behaviorismu a fenomenologie v učení Alfréda Bandury.

Opírá se o premisu, že jednání každého jedince vychází primárně z jeho vnitřních osobních dispozic ovlivňovaných vnějším prostředím $\mathrm{v}$ průběhu celého života. Ve vzájemné interakci uvedených tří faktorů je neustále obsažen člověk jako celek, a to jako předpoklad i jako výsledek těchto procesů. V různých situacích však může jeden z faktorů vystupovat ve svém prostředí výrazněji.

Velkou pozornost věnuje procesům sebeuplatňování z hlediska psychobiologického fungování. Výzkumně byl např́íklad doložen zdravotní důsledek pozitivního sebeuplatnění při vyrovnávání se se stresory. Ukazuje se, že zvyšování pocitu sebeuplatnění příznivě ovlivňuje zdraví a pocit duševní pohody (nap̌r. srdeční tep, krevní tlak) (Michalová, Pešatová 2012).

\section{Stimulace sebeuplatnění vychází ze čtyř zdrojů:}

1. Prvním nejefektivnějším zdrojem je autentická zkušenost se zvládnutím úkolové činnosti. Úspěch posiluje sebedůvěru, neúspěch vyvolává pochybnosti o vlastních schopnostech. Nejúčinnější je zkušenost s překonáváním vlastních překážek vytrvalým úsilím.

2. Druhý zdroj tvoří zástupná zkušenost a výsledky vzorové činnosti druhých lidí. Vzory dodávají pozorovatelům efektivní postupy pro zvládání různých situací. Lidé posuzují částečně své schopnosti srovnáváním se schopnostmi jiných. 
3. Třetí zdroj zahrnuje přesvědčování lidí o tom, že disponují potřebnými schopnostmi. Zpravidla nestačí jen pozitivní ocenění, je třeba zpočátku dávat takové úkoly, které přinášejí úspěch a nestaví člověka předčasně do situace, o které je pravděpodobné, že ji nezvládne.

4. Za čtvrtý zdroj pokládáme informace či úsudek o vlastním tělesném stavu. Únava a somatizace jsou posuzovány jako příznaky fyzické neschopnosti zvládnout úkoly vyžadující sílu a vytrvalost. Napětí (tenze) bývá příznakem vlastní zranitelnosti, předjímá neúspěch (Michalová, Pešatová 2012).

Zvyšování sebedůvěry ve vlastní schopnosti lze proto dosahovat mj. zlepšováním tělesného stavu a redukcí stresu. Celkově lze percepci sebeuplatnění, případně víru v ně, charakterizovat jako pružný systém sebedůvěry, který pomáhá překonávat neúspěchy. Pochybnosti o sebeuplatnění vedou k podstatnému růstu subjektivních obav a fyziologické vzrušivosti. Kognitivní reprezentace cílů a anticipace výsledků jsou součástí sebemotivačního kontrolního systému. Prostřednictvím kognitivní reprezentace se budoucí události mění v běžné motivační faktory chování (Michalová, Pešatová 2012, s. 41-42).

\subsection{Děti s ADHD v mateřské škole}

Významnou institucí ovlivňující osobnost dítěte již od konce batolecího věku je mateřská škola. Působí na rozvoj jeho psychických funkcí, funguje jako důležitý socializační činitel modifikující rozvoj určitých osobnostních vlastností. Eliminuje individuální rozdíly mezi jednotlivými dětmi, vytváří tlak na přizpůsobení se zásadám školského zařízení. Má vůči dětem svoje očekávání, která mohou být pro některé z nich těžko splnitelná. Děti $\mathrm{s} A \mathrm{ADD}$ patří do této skupiny. Snahou pedagogů by měla být snaha o rovnováhu hledisek rozvoje dětské osobnosti ze sociální i individuální pozice každého jedince. Výchova v mateřské škole se přibližuje rodinné výchově. $\mathrm{Na}$ rozdíl od ní však přináší trvalé napětí mezi zdůrazněním 
individuality a spontánnosti přirozeného zrání dítěte a záměrným strukturovaným učením, které se promítá do předškolních vzdělávacích programů.

Cílem edukativního působení v této školské instituci není a ani nemůže být komplexní přebírání výchovných úkolů rodiny za jejich dítě. Tradiční obsah, jako je rozšiřování zkušeností, dovedností a návyků, jí slouží jako prostředky, nikoliv jako cíl plnohodnotného rozvoje dětské osobnosti.

Kromě rodičů je již od dětství pro dítě důležitý vliv vrstevníků. Dítě potřebuje být přjato vrstevnickou skupinou a v jejím rámci uspokojivě hodnoceno. Naplnění této potřeby závisí na tom, jak dokáže s ostatními postupně spolupracovat, jak se umí přijatelně prosadit, což pro dítě s ADHD bývá problém. Nezbytný je nácvik jeho sžívání s vrstevnickou skupinou, která pomáhá utvářet adekvátní prosociální postoje mimo hranice pouhé rodiny.

Heterogenní skupiny vedou k obohacení sociálních vazeb ve skupině, k možnosti pobytu sourozenců ve stejné třídě, usnadňují integrativní začlenění dětí se speciálními vzdělávacími potřebami, tj. jak např. dětí s ADHD, tak i dětí nadaných. Především děti s ADHD obtížně chápou, jaké chování se od nich požaduje, co je dovoleno a co zakázáno. Mohou se sice učit nápodobou chování druhých, ale za těchto okolností jim chybí porozumění podstatě takového projevu. Hůře se sociálně orientují, těžko chápou význam různých situací, nerozumí kontinuitě určitého dění.

Nejednou ani přesně nechápou, co po nich druzí chtějí. Mnohdy nevědí, co si o jejich chování ostatní lidé myslí, a často je to ani vzhledem k aktuální úrovni socialibility nezajímá. Projevují se u nich potíže s delším soustředěním na jednu činnost. Tyto děti bud' u jedné činnosti vůbec nevydrží, nebo pouze částečně. Konkrétně to znamená, že si začnou hrát $\mathrm{s}$ jednou hračkou, najednou ji z ničeho nic nechají být a najdou si jinou. Někdy vydrží u činnosti delší dobu, ovšem jen 
u té, která je pro ně zajímavá, jinou aktivitu striktně odmítají dělat. Např. děti s problémy s grafomotorikou nerady kreslí.

V lepších případech mívají v mateřské škole jen určité výchovné problémy. Nežrídka je jim doporučen odklad školní docházky. Velmi častá jsou nedorozumění v komunikaci mezi rodinou a školou, protože dítě $\mathrm{s} A D H D$ v předškolním věku nebylo ještě plně identifikováno s výkonovou realitou základní školy. Rodiče často dobře míněné rady učitelek považují za přehánění, netoleranci apod.

Typickými projevy u dítěte předškolního věku s ADHD jsou tedy poruchy koncentrace pozornosti, hyperaktivita a impulzivita. Pozornost je typická roztěkaností, nesoustředěností a nepozorností. Častá bývá netrpělivost, snadná odklonitelnost pozornosti či kolísavá pozornost, snadná unavitelnost. Hyperaktivita se projevuje nadměrnou nebo vývojově nepřiměřenou úrovní motorické či hlasové aktivity. Mezi konkrétní projevy patří psychomotorický neklid - neustálý pohyb, poskakování, rychlé pohyby, drobné pohyby rukou či nohou, záškuby mimického svalstva, obtíže s usínáním a jiné. Dítě je v celkovém napětí, fyzickém i psychickém. V řečovém projevu se vyskytuje překotnost, hlasité mluvení či překřikování. Hypoaktivita se projevuje pomalostí, těžkopádností, utlumeností až apatií, může se vyskytnout i nemotornost. Impulzivita bývá spojena se sníženými volními, ovládacími schopnostmi. Jedná se o hlučné, spontánní, živelné a zbrklé chování, dále o neschopnost domýšlet důsledky svého jednání, obtíže při činnostech, které vyžadují čas. Děti s ADHD bývají citlivější než ostatní děti a na jakýkoliv pocit nejistoty reaguje nepřátelsky (Train 1997).

Rovnoprávnost vztahu mezi mateřskou školou a rodinou se projevuje v možnosti volného výběru a přístupu rodičů. Pluralismus zřizovatelů mateřských škol přináší možnosti vytvářet takové varianty výběru, které vyhovují většině dětí i rodičů. Máme na mysli mateřské školy veřejné, soukromé, nezávislé, alternativní... Posílení autonomie veřejných předškolních zařízení uvolnilo učitelkám prostor pro vlastní rozhodovací strategii, kreativitu, tvořivost. 
Mateřská škola je v České republice legislativně zakotvena v zákoně 561/2004 Sb., školský zákon, jako nedílná součást vzdělávací soustavy, škol a školských zařízení.

\subsection{Rámcový vzdělávací program pro předškolní vzdělávání}

Rámcový vzdělávací program pro předškolní vzdělávání (dále jen RVP-PV) coby kurikulární dokument byl upraven podle návrhu školského zákona (zákona č. 561/2004 a zákona č. 49/2009 Sb.). Jeho vytvoření předcházelo tvorbě programu pro základní vzdělávání. Formuluje obecné cíle předškolního vzdělávání a jeho rámcový obsah. Jednotlivé MŠ si následně zpracovávají vlastní školní vzdělávací programy (dále jen ŠVP), které s RVP korespondují. Celý tento dokument RVP-PV je možné podrobně prostudovat na internetových stránkách ministerstva školství mládeže a tělovýchovy.

Hlavním principem RVP-PV se stává akceptace vývojových odlišností dětí předškolního věku a jejich systematické zakomponování do obsahu, forem a metod vzdělávání při respektování individuálních specifik každého z nich. Považuje se za samožrejmost nabídnout rozvoj a vzdělávání každému jednotlivci a utvářet klíčové kompetence, kterých je možné dosáhnout v předškolním věku. Kvalitu předškolního vzdělávání zajištuje možnost přizpůsobení obsahu jednotlivých ŠVP z pohledu cílů, obsahu a podmínek jednotlivých MŠ. Každá z nich má možnost individuální profilace, dostává se jí prostor pro vlastní využití různých forem a metod vzdělávání a přizpůsobení edukace podmínkám, potřebám a možnostem, které jsou dané určitému regionu - oblasti, dávat rámcová kritéria, která budou aplikována pro vnější i vnitřní hodnocení mateřské školy i dávanému vzdělávání. 
Tabulka 4: Systém vzdělávacích cílů (RVP-PV 2004, s. 8)

\begin{tabular}{|c|c|c|}
\hline \multicolumn{3}{|c|}{ Vzdělávací cíle } \\
\hline \multirow[b]{2}{*}{$\begin{array}{l}\text { vúrouni } \\
\text { obecné }\end{array}$} & formulované jako záměry & formulované jako výstupy \\
\hline & $\begin{array}{l}\text { Rámcové cíle: } \\
\text { 1. Rozvíjení dítěte, jeho učení } \\
\text { a poznání } \\
\text { 2. Osvojení hodnot } \\
\text { 3. Získání osobnostních } \\
\text { postojů }\end{array}$ & $\begin{array}{l}\text { Klíčové kompetence: } \\
\text { 1. kompetence k učení } \\
\text { 2. kompetence k řešení } \\
\text { problémú } \\
\text { 3. kompetence komunikativní } \\
\text { 4. kompetence sociální } \\
\text { a personální } \\
\text { 5. kompetence činnostní } \\
\text { a občanské }\end{array}$ \\
\hline \multirow{4}{*}{$\begin{array}{l}\text { v úrouni } \\
\text { oblastní }\end{array}$} & $\downarrow$ & $\mathrm{A}$ \\
\hline & Dílčí cíle v oblastech: & $\begin{array}{l}\text { Dílčí výstupy (dílčí poznatky, } \\
\text { dovednosti, hodnoty a postoje) } \\
\text { v oblastech: }\end{array}$ \\
\hline & $\begin{array}{l}\text { 1. biologické } \\
\text { 2. } \text { psychologické }\end{array}$ & 1. biologické \\
\hline & $\begin{array}{ll}\text { 3. } & \text { interpersonální } \\
4 . & \text { sociálně-kulturní } \\
5 . & \text { environmentální }\end{array}$ & $\begin{array}{l}\text { 3. } \\
\text { 3. } \text { interpersonální } \\
\text { 5. }\end{array}$ \\
\hline
\end{tabular}

RVP PV pracuje se čtyřmi skupinami cílů, viz tabulka 4. První částí jsou cíle rámcové, které vyjadřují univerzální úmysl předškolního vzdělávání. Další skupinou jsou klíčové kompetence - ty znázorňují výstupy, které jsou obecnější, a je nutné jich dosáhnout v předškolním vzdělávání. Za další oddíl jsou považovány dílčí cíle, které vyjadřují konkrétní záměry daných vzdělávacích oblastí. Na posledním místě jsou dílčí výstupy, které jsou dílčími poznatky, postoji, hodnotami, dovednostmi a odpovídají cílům dílčím.

„Tyto cílové kategorie jsou těsně provázané a vzájemně spolu koresponduji. Tento systém by měl být funkční. Ukazuje, že vědomé a systematické sledováni a naplňováni stanovených záměrů v běžné každodenni praxi by mělo spolehlivě vést $k$ dosahování výstupü. Pracuje-li tedy pedagog při vzděláváni dětí průběžně s vědomím 
vzdělávacích záměrů (at’ už v úrovni obecné či oblastní), měl by mít záruku, že skutečně vede děti kosvojování kompetencí a k jejich postupnému zdokonalováni" (RVP-PV 2004, str. 7).

V kurikulárních dokumentech mají tedy své místo klíčové kompetence - k učení, k řešení problémů, kompetence komunikativní, sociální a personální, kompetence činnostní a občanské. Můžeme je obecně nazývat jako cílovou kategorii výstupních vědomostí, schopností, postojů, dovedností a hodnot, které jsou důležité pro rozvoj každého člověka a jeho budoucí uplatnění.

Jejich dosažení je procesem dlouhodobým a složitým, který začíná v předškolním vzdělávání a pokračuje v základním a středím vzdělávání a postupně se dotváří v dalším průběhu života. Vzdělávací obsah v RVP-PV představuje hlavní prostředek vzdělávání dítěte v MŠ. Je vymezen tak, aby sloužil pedagogovi jako základ pro vlastní nabídku, kterou formuluje v třídním vzdělávacím programu. Umožňuje tedy každému pedagogovi samostatně tvořit integrované bloky učiva a očekávaných výstupů, které budou vyhovovat konkrétní skupině dětí pro danou třídu. Vzdělávací obsah se stanovuje pro celou skupinu společně, pro děti ve věku od tři do šesti až sedmi let. Je koncipován do pěti vzdělávacích oblastí, jako jsou oblasti biologické, psychologické, interpersonální, sociálně-kulturní a environmentální: dítě a jeho tělo, dítě a jeho psychika, dítě a ten druhý, dítě a společnost, dítě a svět.

Kromě výše uvedeného musí být $\mathrm{v}$ mateřské škole zabezpečeny správné podmínky pro realizaci předškolního vzdělávání. Tyto podmínky je nutné dodržovat. Jedná se o věcné podmínky, které označujeme jako materiální vybavenost mateřské školy a její prostor. Další podmínkou je životospráva, kdy musí být dětem nabízena strava podle daných předpisů. Do této oblasti zařazujeme také dostatek volného pohybu dětí a dostatek pobytu na čerstvém vzduchu, nesmí být opomenuta individuální potřeba spánku a odpočinku. Psychosociální podmínky zabezpečují dětem cítit se v mateřské škole spokojeně, mít pocit bezpečí a umožňovat jim postupnou adaptaci. Nejsou opomíjeny podmínky související s organizací, 
řízením mateřské školy, personálním a pedagogickým zajištěním a důležitou spoluprací s rodiči.

Stěžejní pro zdárný vývoj dítěte je především odpovídající výchovný přístup $\mathrm{v}$ rodině a $\mathrm{v}$ mateřské škole. Výchova může další vývoj dítěte ovlivnit nejen pozitivně, ale i negativně. Podpưrnou pomocí jedincům s ADHD je farmakologická léčba pod vedením psychiatra, dále kombinace kognitivně-behaviorální terapie a terapie rodinné, jejichž cílem je pokusit se vhodnou manipulací vnějšího prostředí změnit vzorec chování dítěte, a tak dospět $\mathrm{k}$ jeho vnitřní změně.

Doporučujeme, aby učitel(ka) uplatȟovala tyto výchovné zásady, které by měly korespondovat $s$ přístupem v rodině:

1. Při jednání s dítětem bud'me laskaví, klidní, trpěliví, optimističtí, di̊slední. Všestrannou podporu by dítě mělo nacházet především $\mathrm{v}$ rodině.

2. Posilujeme sebevědomí dítěte, především tím, že oceníme každý jeho úspěch a snahu, nejen bezchybný výkon. Často musíme sami vytvářet podmínky k tomu, abychom mohli pochvalu a ocenění projevit.

3. Při práci dítě vedeme, povzbuzujeme a uklidňujeme slovně i dotykem. Snažíme se předejít chybám a nevhodnému chování.

4. Veškeré aktivity dělíme na poměrně krátké intervaly (přibližně po 10-15 minutách), nezapomínáme na odpočinek.

5. Dítěti umožníme dostatek spontánní hry a pohybu. Řešením většinou nejsou aktivity v rámci sportovních kroužků a oddílů, nebot řízená pohybová činnost těmto dětem vždy radost a uvolnění nemusí přinést.

6. Dítěti bychom měli umožnit volit si při hře i práci polohu podle jeho aktuální potřeby, klidně vleže, vkleče, vestoje nebo i v pohybu. 
7. Snažíme se předcházet nedorozuměním v komunikaci mezi rodinou a školou a co nejvíce podněcujeme vzájemnou komunikaci a spolupráci. Je třeba počítat $\mathbf{s}$ nižší samostatností dítěte a s nutností vyšší míry jeho vedení a podpory.

8. Nenechávejme dítě prožívat své neúspěchy o samotě, šetrně je s ním probírejme a vytvářejme včas jejich hodnotné protiklady. Nevzdávejme se ani tehdy, jsou-li obtíže dítěte velmi výrazné, nezapomínejme na možnost konzultovat nesnáze s odborníky.

Obecně platí: pracuje-li dítě pod kontrolou, jsou jeho výsledky mnohem lepší. Dospělý za dítě musí držet hranice, strukturovat pracovní proces, eliminovat rušivé vlivy z okolí aj. Další doporučení mohou vyplynout ze závěrů odborného vyšetření dítěte.

Úkolem učitelky není odstraňování nežádoucích projevů dítěte. $\mathrm{V}$ jejích možnostech však bývá upravovat podmínky výuky tak, aby se minimalizoval vliv negativních projevů dítěte na vztahy v kolektivu dětí. Pohled dítěte může být často odlišný od vnímání situace ze strany učitele. Dětem by proto měly být ze strany pedagogů vytvářeny příležitosti ke sdělení svých pocitů a prožívaných obtíží ve výuce nebo mezi spolužáky. Základem je vztah založený na důvěre a respektování přirozené autority učitelky. Pochvala a pozitivní hodnocení působí jako zpevnění žádoucího chování. Užitečnou pedagogickou strategií je častá zpětně podávaná informace o kvalitě plnění požadované činnosti a posilování musí následovat ihned po splnění úkolu, vztahuje se přitom i na úkoly, jejichž plnění očekáváme u jiných dětí jako samozřejmé. Případné upozorňování na chyby by mělo být konkrétní, krátké a jasné. V jednání s dítětem zachováváme klid, mluvíme klidným hlasem, upřednostňujeme kontakt $\mathrm{z}$ očí do očí. K ověření pochopení a zapamatování toho, co má dítě v danou chvíli dělat, je vhodné dítě nechat instrukce zopakovat. Náročnost a rozsah zadávaných úkolů by měly vycházet z konkrétních možností každého jednotlivého dítěte. 


\subsection{Tematické členění osobnostní a sociální výchovy}

„Průřezové téma OSV reflektuje osobnost žáka, jeho individuální potřeby i zvláštnosti, je praktické a má každodenní využití v běžném životě. Jeho smyslem je pomáhat každému žákovi utvářet praktické żivotní dovednosti“ (RVP-ZV - MP 2006, s. 69).

Při aplikaci Osobnostní a sociální výchovy dle RVP do výuky se učivem stává sám žák, konkrétní žákovská skupina včetně běžných situací každodenního života. Jejím smyslem je pomáhat každému žákovi hledat vlastní cestu k životní spokojenosti, která je založena na dobrých vztazích $\mathrm{k}$ sobě samému i k dalším lidem a světu.

\section{Přínos průr̆ezového tématu k rozvoji osobnosti žáka}

V oblasti vědomostí, dovedností a schopností průřezové téma:

- Vede k porozumění sobě samému a druhým.

- Napomáhá k zvládání vlastního chování.

- Přispívá k utváření dobrých mezilidských vztahů ve třídě i mimo ni.

- Rozvíjí základní dovednosti dobré komunikace.

- Utváří a rozvíjí základní dovednosti pro spolupráci.

- Umožňuje získat základní sociální dovednosti pro řešení různých situací (např. konfliktů).

- Podporuje dovednosti a přináší vědomosti týkající se duševní hygieny.

V oblasti postojů a hodnot průr̆ezové téma:

- Pomáhá k utváření pozitivního (nezraňujícího) postoje k sobě samému a k druhým.

- Vede k uvědomování si hodnoty spolupráce a pomoci.

- Vede k akceptaci různých typů lidí, názorů, př́ístupů k řešení problémů.

- Přispívá k uvědomování mravních rozměrů různých způsobů lidského chování. 
- Napomáhá primární prevenci sociálně patologických jevů a rizikového chování.

Můžeme tedy říci, že u žáků postupně posiluje:

- kreativitu a iniciativu,

- odpovědnost k sobě a druhým,

- schopnost v konkrétní situaci včas a vhodně reagovat,

- schopnost reflektovat své jednání,

- ochotu naslouchat, zájem o druhé,

- sociální a komunikační dovednosti,

- důvěru ve vlastní schopnosti,

- umění spolupráce,

- otevřenost k možnostem, které přináší konkrétní životní situace.

\section{Tematické okruhy průřezového tématu}

Tematické okruhy Osobnostní a sociální výchovy jsou členěny do tří částí, které jsou zaměřeny na osobnostní, sociální a mravní rozvoj. Pro jejich realizaci je užitečné zařazovat do výuky ta témata, která reflektují aktuální potřeby žáků v konkrétní třídě, popřípadě vycházejí ze vzájemné domluvy s nimi. K shromažd’ování témat vhodných k aplikaci do OSV doporučujeme využít jednoduchou pomůcku zvanou Krabice problémů.

Ve třídě umístíme schránku, do níž v průběhu dne/týdne žáci vhazují lístečky s problémy a náměty, které by bylo vhodné v kolektivu třídy řešit. Nese název Krabice problémů. Zpočátku, než se žáci naučí krabici používat, je vhodné, aby si nějakou situaci $\mathrm{k}$ řešení promyslel učitel, napsal na lístek a do krabice ji vhodil. Na tomto modelovém problému či situaci předvede žákům, jak budou společně situaci řešit.

Metoda spočívá $\mathrm{v}$ hledání způsobu, jak vhodně vyřešit určité problémy, které se vyskytly ve třídě a týkají se všech žáků. Nemusí se jednat o žádný komplikovaný problém, ale o situace tzv. běžného dne. Napřn. děti se mohou domlouvat, jak se budou střídat v péči o zalévání květin. 
Cílem této intervence je přivést žáky $\mathrm{k}$ promyšlenému zpơsobu řešení každodenních situací a postupně odbourávat impulzivní nepromyšlené řešení problému bez domyšlení jeho následku. Dalším cílem je ovlivňovat nevhodnou komunikaci mezi žáky a nevhodné vyjadřování a směrovat je k využívání pozitivní komunikace. Právě tyto okamžiky však bývají v Osobnostní a sociální výchově velmi užitečné, nebot nabízejí př́iležitost k přemýšlení o tom, co se děje.

\section{Tematické okruhy průr̆ezového tématu OSV jsou následující:}

\section{Osobnostní rozvoj}

- Rozvoj schopností poznávání - cvičení smyslového vnímání, pozornosti a soustředění; cvičení dovedností zapamatování, řešení problémů; dovednosti pro učení.

- Sebepoznání a sebepojetí - já jako zdroj informací o sobě; druzí jako zdroj informací o mně; moje tělo, moje psychika (temperament, postoje, hodnoty); co o sobě vím a co ne; jak se promítá mé já v mém chování; můj vztah ke mně samé/mu; moje učení; moje vztahy k druhým lidem; zdravé a vyrovnané sebepojetí.

- Seberegulace a sebeorganizace - cvičení sebekontroly, sebeovládání - regulace vlastního jednání, prožívání, vůle; organizace vlastního času.

- Psychohygiena - dovednosti pro pozitivní naladění mysli a dobrý vztah k sobě samému; sociální dovednosti pro předcházení stresům v mezilidských vztazích; organizace času; dovednosti zvládání stresových situací (rozumové zpracování problému, uvolnění - relaxace, efektivní komunikace atd.); hledání pomoci při potížích.

- Kreativita - cvičení pro rozvoj základních rysů kreativity (pružnosti nápadů, originality, schopnosti vidět věci jinak, citlivosti, tvořivosti v mezilidských vztazích). 


\section{Sociální rozvoj}

- Poznávací schopnosti - vzájemné poznávání se ve skupině/třídě; rozvoj pozornosti vưči odlišnostem a hledání výhod v odlišnostech; chyby při poznávání lidí.

- Mezilidské vztahy - péče o dobré vztahy; chování podporující dobré vztahy, empatie a pohled na svět očima druhého, respekt, podpora, pomoc; lidská práva jako regulativ vztahů; vztahy a naše skupina/třída (práce s přirozenou dynamikou dané tř́idy jako sociální skupiny).

- Komunikace - řeč těla, řeč zvuků a slov, řeč předmětů a prostředí vytvářeného člověkem, řeč lidských skutků; cvičení pozorování a empatického a aktivního naslouchání; dovednosti pro sdělování verbální i neverbální (technika řeči, výraz řeči, cvičení v neverbálním sdělování); specifické komunikační dovednosti; dialog (vedení dialogu, jeho pravidla); komunikace v různých situacích (informování, odmítání, omluva, pozdrav, prosba, přesvědčování, řešení konfliktů, vyjednávání, vysvětlování, žádost apod.); asertivní komunikace, dovednosti komunikační obrany proti agresi a manipulaci, otevřená a pozitivní komunikace; pravda, lež a předstírání v komunikaci.

- Spolupráce a soutěživost - rozvoj individuálních dovedností pro spolupráci (nesouhlas, odpor apod., dovednost odstoupit od vlastního nápadu, pozitivní myšlení apod.); rozvoj sociálních dovedností pro spolupráci (jasná a respektující komunikace, řešení konfliktů, podřízení se); rozvoj individuálních a sociálních dovedností pro zvládání soutěže a konkurence.

\section{Morální rozvoj}

- Ǩešení problémů a rozhodovací dovednosti - dovednosti pro řešení problémů a rozhodování z hlediska různých typů problémů a sociálních rolí - problémy v mezilidských vztazích, zvládání učebních problémů. 
- Hodnoty, postoje, praktická etika - vytváření povědomí o kvalitách typu odpovědnost, spolehlivost, spravedlivost, respektování atd.; pomáhající a prosociální chování (člověk neočekává protislužbu); dovednosti rozhodování v eticky problematických situacích všedního dne.

\section{Obsahově můžeme OSV rozčlenit na:}

\section{Oblast osobnostních kompetencí}

- Sebepoznání a tvorba vyrovnaného sebepojetí.

- Zdokonalení základních kognitivních funkcí.

- Seberegulace a organizace vlastního života.

- Psychohygiena.

- Kreativita v každodenním životě.

Oblast sociálních kompetencí

- Poznávání lidí.

- Tvorba mezilidských vztahů.

- Komunikace.

- Spolupráce a soutěžení.

\section{Oblast morálních kompetencí, hodnot a morálky}

- Hodnoty, postoje, mravní vlastnosti člověka; prosociálnost; etika všedního dne.

- Řešení problémů, rozhodovací dovednosti v situacích se sociálně etickým potenciálem.

Doplňková oblast osobnostně sociálních kompetencí aplikovaných na určité role a situace

- Já a jiní lidé v mých životních situacích.

- Já a mé sociální role.

Pokud se učiteli nepodaří navázat se žáky zejména s ADHD skutečné opravdové kontakty, musí je udržovat pohromadě různými sankcemi, silným tlakem nebo poskytováním materiálních výhod. Často si pedagog uvědomí, že ve třídě není něco tzv. v pořádku, ale nezná cestu, jak situaci řešit. Z praxe je známo, že se takový pedagog 
uchyluje k získávání informací o vnitřním životě třídy přes některého jejího žáka a přes něj se také snaží kohezi skupiny ovlivnit. Takový pokus většinou nevede $\mathrm{k}$ trvalému řešení. Cúlem OSV je tedy mimo jiné ovlivnit strukturu a dynamiku třídy tak, aby se v ní utvořila pozitivní skupinová atmosféra směrující jednotlivé žáky $\mathrm{k}$ zodpovědnosti za své chování a jednání. K tomu může dojít jen za předpokladu, že dojde ke stavu, při kterém budou uspokojovány v maximální možné míre jak potřeby jednotlivců, tak potřeby třídy, ale nejen na platformě třídní, nýbrž celoškolní (Michalová, Pešatová 2012).

\section{Vělenění osobnostní a sociální výchovy do školního rozvrhu}

Valenta (2006) doporučuje následující možnosti:

1. Uplatnění témat OSV prostřednictvím efektivního chování a jednání učitelů (učitel jako model jednání a jako osoba pěstující dobré vztahy).

2. Využití potenciálu témat OSV v různých (běžných) školních situacích (reflexe témat OSV v jakýchkoliv školních situacích, v nichž je možné udělat pedagogickou reflexi).

3. Včlenění témat OSV do jiných předmětů, resp. oblastí či oborů vzdělání a výchovy (kroskurikulární přístup; integrace obsahů a metod předmětů a OSV; OSV v rámci předmětových projektů).

4. Včlenění témat OSV do práce školy v samostatných časových blocích (projekt k OSV; kroužek; klub; třídnická hodina; předmět).

Na základě našich praktických zkušeností můžeme konstatovat, že čtvrtá možnost je pro práci s žáky s ADHD nejefektivnější.

\section{Upozornění}

V ideálním případě by měla výuka OSV trvat 20 až 30 minut denně 4-5krát týdně, obzvláště u dětí s poruchou chování, s poruchou adaptace či s lehkou mentální retardací. V souvislosti s délkou trvání 
jedné hodiny můžete zkusit přizpůsobit dobu výuky rozvrhu třídy a potřebám dětí po dohodě s vedením školy. S ohledem na složitost školního rozvrhu může být obtížné zařadit lekce OSV kdykoli by si to pedagog přál. Nicméně se domníváme, že by se hodiny měly konat alespoň 3krát za týden, abyste dosáhli očekávaných výsledků. Nejčastějším modelem je oficiální zařazení OSV do rozvrhu v rozsahu 1 hodina týdně. Doporučujeme věnovat se každé lekci tak dlouho, dokud žáci vše dobře nepochopí. Nijak vám nepomůže, když budete probíranou látku uspěchávat a probírat těžší učivo dříve, než děti aktuálně probíranou látku takzvaně nezažijí a neidentifikují se s ní (Michalová, Pešatová 2012).

\section{Způsoby výuky osobnostní a sociální výchovy}

Při výuce OSV je důležité dodržovat 3 základní zásady:

1. Musí být vyučována prakticky, multisenzoriálně.

2. Jednotlivá témata musí každý žák zažít osobně, nezprostředkovaně.

3. Musí mít ze strany pedagoga tzv. provázející charakter.

Praktický charakter výuky vychází z předpokladu, že se každý z žáků ve svém každodenním životě s mnohými uvedenými tématy v OSV setkává. Máme na mysli neplánované osobní prožívání situací, v nichž hrají důležitou úlohu vzájemné mezilidské vztahy, empatie, tolerance, porozumění sobě samému i druhým lidem (dospělým i vrstevníkům). Žáci se v těchto situacích sami učí, jak reagovat, který způsob chování a jednání je společensky přijatelný a který nikoliv apod. Ve školním prostředí tyto situace též vznikají zcela přirozeně, ale mnohé děti nejsou schopny v nich adekvátně fungovat. Proto se od učitele v rámci OSV očekává schopnost tyto situace uměle a vhodně navozovat, aby žák získával osobní zkušenost $\mathrm{s}$ jejich řešením v oblasti uvedených témat. Osobní zážitek spočívá v zajištění reálné možnosti nabývat osobní zkušenosti při řešení různých životních (problémových) situací pro každého žáka. Tato zkušenost musí být zhodnocena ve vztahu $\mathbf{k}$ jeho vlastnímu životu. $\mathrm{K}$ tomu slouží 
zejména tzv. reflexe, tedy rozebírání nabyté zkušenosti v konkrétních situacích, nejen v hodinách OSV (Michalová, Pešatová, 2012).

Naplnění provázejícího charakteru OSV je plně v kompetenci každého pedagoga.

Ten promýšlí a následně vytváří konkrétní podmínky pro nabývání pozitivních osobnostních rysů, efektivních sociálních dovedností a morálně hodnotných i hodnotících postojů každého svého žáka. Přitom ovšem musí respektovat jeho osobní zvláštnosti, speciální vzdělávací potřeby apod.

Učitel formuluje pro žáky otázky, na které si hledají odpovědi především oni sami. Směruje je k efektivnímu výběru vlastních hodnot. Nenásilně formuje vhled každého žáka na vlastní chování, akceptaci a dodržování společenských pravidel apod.

Někteří žáci, především ti se speciálními vzdělávacími potřebami, totiž zažili v průběhu vzdělávání negativní situace s vrstevníky. Někteří z nich nedokáží navázat a udržet přátelský vztah nebo jsou limitováni v rozvoji sociálních dovedností přítomností svého handicapu. Důsledkem může být skutečnost, že jsou vrstevníky odmítáni a mají obavy se účastnit v rámci třídy či školy jakékoliv aktivity. Výsledkem odmítání mohou být kromě izolace i různé druhy výhrůžek a narážek, vylučování ze hry, rozvíjející se prešikana apod. Takový žák často na vzniklou situaci reaguje nevhodným chováním, předváděním se, šaškováním, snižující se autoregulací vlastních reakcí. Může se ale i naopak stáhnout do svého vnitřního světa a na okolí reagovat nemístnou afektivitou, agresivitou, vulgarismy, odmítáním, neochotou apod. Osobní nespokojenost a nepohoda se velmi často promítá i do snižujícího se školního výkonu. Lze tedy říci, že narůstající problémové chování významně znevýhodní pozici a roli žáka ve všech sociálních prostředích, jichž je členem, školní třídu nevyjímaje. 
Mezi výukové prostředky a strategie, které se dají dobře použít k rozvoji jednotlivých kompetencí proklamovaných v OSV, patří především:

- napodobování,

- identifikace,

- př́imý pokyn,

- brainstorming s tématy pocitů a rozlišení pocitů pozitivních a negativních za pomoci pocitových karet a následně bez nich,

- brainstorming se zaměřením na řešení vyskytujících se problémů v třídním společenství,

- skupinová práce, práce ve dvojici - směřuje k posílení kooperace, ohleduplnosti, empatie,

- diskuzní skupiny,

- vytváření pravidel a jejich dodržování,

- práce s chybou a autokorekce,

- využívání motivačních razítek, nálepek, bodovacích přehledů,

- rutinní procvičování adekvátního sociálního chování,

- dramatizace, rolové hry, psychosociální hry,

- pracovní listy, rébusy se sociálním obsahem,

- čtení a vyprávění příběhů vypovídajících o problémových situacích jako námět $\mathrm{k}$ diskusi řešení dané situace a předvídání dopadu jednání jejich hlavních postav,

- nácvik strategií autoregulace (sebeovládání, sebekontrola),

- reálné sebehodnocení svého chování, jednání.

\section{Příprava na výuku OSV}

Příprava na výuku OSV vyžaduje více času. Je velice vhodné projít oficiálním školením, při němž můžete získat obecný náhled na její výuku, způsoby implementace. Během př́ípravy na OSV si vybavte nedávné konkrétní situace se žáky ve třídě nebo na hřišti, které by mohly být relevantní $\mathrm{k}$ diskusi $\mathrm{v}$ třídním prostředí. Č́m více budou vaše příklady smysluplné, tím více se děti s nimi ztotožní a lépe porozumí probírané látce. Tímto způsobem můžete rozšířit a přiblížit všechny situace, s nimiž přijdete v průběhu školních dnů s dětmi do 
styku. Jejich řešení by mělo odpovídat skutečným emocionálním potřebám dětí. Není dobré předstupovat před žáky s tím, že chci s nimi řešit určitý problém a působím přitom nejistě a rozpačitě. Doporučujeme vám proto domluvit se zpočátku na př́ípravě s asistentem pedagoga nebo s kolegou, který může poradit, nebot daný problém může vidět ze zcela jiného úhlu pohledu. Tyto konzultace vám velmi pomohou získat jistotu. Při výměně zkušeností a při odstraňování problematických situací a překážek, na které můžete narazit až při přímé práci se žáky, stále rozvíjíte vlastní sociální dovednosti (Michalová, Pešatová, 2012).

Především nezapomeňte, že výuka OSV se opírá o motivaci žáků ke komunikaci. Její nedílnou součástí jsou:

a) potřeba ztotožnit se s druhými,

b) potřeba být akceptovaným členem vrstevnické skupiny,

c) potřeba kontroly vlastního vlivu na druhé.

V mnoha ohledech náš školský systém poskytuje žákům zázemí, které není tradiční v jiných tzv. vyspělých zemích. Dospívání představuje vývojové období, které si zaslouží pozornost a péči dospělých. Rozvoj sociálních dovedností je v této životní etapě nesmírně důležitý a škola se svými tradičními charakteristikami k němu nabízí mnoho př́ležitostí, které je vhodné využít (Michalová, Pešatová 2012). 
Determinanty inkluzivního vzdèláváni dětí s ADHD 


\section{Dítě s ADHD a digitální technologie}

Technologický vývoj voblasti digitálních technologií významným způsobem ovlivňuje životy lidí napříč věkovými skupinami, profesemi a zeměmi, ve kterých žijí. Digitální technologie (často také označované jako informační a komunikační technologie - ICT) se velmi rychle vyvíjejí - každoročně přicházejí na trh nové produkty, které mají nové užitné vlastnosti a přinášejí nové možnosti použití. Digitální technologie také zásadním způsobem ovlivňují vzdělávací proces ve většině oblastí a kategorií, zejména formální školní vzdělávání realizované institucionálně dle závazných kurikulárních dokumentů a neformální vzdělávání - žáci tráví u počítačủ připojených $\mathrm{k}$ internetu stále více času, vyhledávají různé informace, využívají nejrůznější specializované služby a zapojují se do on-line sociálních sítí. Přitom se také zdokonalují v ovládání počítačů a různých programů. To vše přispívá $\mathrm{k}$ jejich individuálnímu rozvoji, žáci získávají nové informace, učí se ze sdílených zkušeností jiných a osvojují si nové pracovní postupy. Vzniká akutní potřeba každého žáka naučit se ovládat digitální technologie tak, aby byly využívány smysluplně a efektivně a aby nebezpečí vyplývající z jejich chybného používání či možného úmyslného zneužití bylo co nejmenší.

Moderní technologie pronikají do škol a „kličovým důvodem, proč jsou začleňovány do vyučování a učení je bezesporu očekávání, že tak dojde ke zkvalitnění učeni žáků a zlepšeni jejich výsledkư“ (Mehlinger, Powers 2003 in Zounek 2009). Je však nezbytné, aby pedagogové i žáci využívali digitální technologie metodicky i didakticky správně tak, aby ke zlepšení výsledků učení skutečně došlo. Domanja např. uvádí Rosenův experiment, při kterém zkoumal 300 žáků a studentů (od 2. stupně ZŠ po vysokoškoláky) při studiu v domácích podmínkách. Experiment přinesl zajímavý závěr, že doba respondentova plného soustředění před prvním rozptýlením činí bez ohledu na věk 
průměrně 3 minuty, přičemž většina rušivých elementů přichází z Facebooku, SMS a z dalších služeb poskytovaných digitálními technologiemi, a to i z více zařízení současně při provádění multitaskingu (Domanja 2015). Ukazuje se však, že u žáků s ADHD může pozitivní motivace vyplývající $\mathrm{z}$ atraktivity vhodných počítačových programů dočasně převážit nad projevy nepozornosti a hyperaktivity jedinců s ADHD. Drtílková (2007) konstatuje: „Každé dítě vydrži déle u činnosti, která ho baví, a naopak nezajímavé a nudné činnosti odbývá nebo od nich utíká. U dětí s hyperkinetickou poruchou to platí dvojnásobně. Bez ohledu na projevy hyperaktivity a nepozornosti se rada těchto dětí dokáže soustředit při práci s počítačem, relativně dlouhou dobu vydrží sedět u monitoru a hrát hry nebo - starši děti - surfovat po internetu podle zájmu."

Také Train (1997) konstatuje, že delší doba hraní na počítači stimuluje u dítěte se syndromem ADHD schopnost delšího soustředění na jednu činnost. Dle jeho názoru je také u počítače, kterému dobře rozumí, i méně zranitelné.

Pedagogové nemohou stát stranou těchto procesů a používat digitální technologie způsobem, který je žákům cizí a není v souladu s tím, jak se žáci učí moderní technologie používat ve škole. Pedagog by měl aktivně vstupovat do sociálního světa žáků a studentů prostoupeného moderními digitálními technologiemi. Aby se nestal v očích žáků digitálně znevýhodněným člověkem, měl by mít alespoň rámcové znalosti o tom, jaké digitální technologie žáci každodenně používají a jakým způsobem je využívají (Pešat 2012).

Ukazuje se však, že intenzivní používání digitálních technologií může mít negativní důsledky. V kontextu poruchy ADHD lze např. uvést Hallowelův návrh na vymezení specifického projevu přetížení psychických funkcí člověka způsobeného častým a intenzivním použiváním digitálních technologií, který nazývá attention deficit trait (ADT), což volně přeloženo znamená př́íznak poruchy pozornosti a jehož 
symptomy charakterizuje takto: roztěkanost, netrpělivost a zuřivost. Lidé s ADT mají problémy s organizací práce v kolektivu, se stanovením priorit a efektivním využíváním času - tyto symptomy hatí výsledky práce jinak nadaných jedinců. Naštěstí se ukazuje, že tyto příznaky (které by laik snadno mohl zaměnit za symptomy ADHD) samovolně odezní po odstranění př́ičiny, tj. vyčerpávající práce s digitálními technologiemi. Výše uvedený text lze sice chápat jako určitou nadsázku, Hallowellowy zkušenosti z jeho psychiatrické praxe však zřejmě může subjektivně potvrdit mnoho lidí, kteří u počítače tráví mnoho času.

$\mathrm{V}$ podobně varovném tónu se vyjadřuje Rosen ve svém blogu $A D H D$ a technologie: pomozme našim dětem získat zpět soustředění a pozornost. Uvádí: „Myslím, že dalším sociálním faktorem, který v USA přispívá $k$ »epidemii ADHD" azůstává nepovšimnut, je rostoucí silný rozpor mezi velmi striktně organizovaným a náročným školním prostředím a velmi stimulujicím digitálním světem, ve kterém mladí lidé tráví svůj volný čas. Digitální život se svými živými hrami a vzrušujícími sociálními médii je světem bezprostřední radosti, kde lze vokamžiku uspokojit prakticky libovolné přáni nebo fantazii. Naopak škola se může jevit ditěti lačnému novot žijicímu na začátku 21. století jako ještě nudnějši a jednotvárnějši než kdykoliv predtím. Relativně fádni školní prostředi dává vyniknout nepozornému chování žáků, které učitelé více vnímaji a následně vyvolávaji tlak na častější diagnostikování symptomů poruch pozornosti“ (Rosen 2014).

Digitální technologie významně ovlivňují jedince se zdravotním postižením. Mohou výrazně napomoci při odstraňování překážek - jsou využívány v tzv. asistivních technologiích, které pomáhají jedincům se zdravotním postižením kompenzovat oslabení fyzických nebo psychických funkcí. Nedostatek zájmu, společenské podpory nebo příležitosti k ovládnutí digitálních technologií na potřebné úrovni může jedince ekonomicky či sociálně znevýhodnit. Lze dokonce hovořit o tzv. digitálním znevýhodnění, při kterém jedinec nemůže nebo 
neumí smysluplně a efektivně využívat digitální technologie při práci i v běžném životě.

Žáci se speciálními vzdělávacím potřebami, žáky s poruchou ADHD nevyjímaje, jsou digitálním znevýhodněním ohroženi více než jejich spolužáci v hlavním vzdělávacím proudu. Vzdělávací strategie a postupy uplatňované při edukaci žáka se SVP musí plnit závazné vzdělávací cíle, zohlednit jeho individuální speciální vzdělávací potřeby a odpovídat dosaženému stupni vědeckého poznání jak z hlediska vlastního vzdělávacího obsahu, tak i z hlediska používaných pedagogických metod a vzdělávacích technologií včetně těch digitálních. V individuálních případech je vždy zapotřebí správně identifikovat konkrétní programy (aplikace), které podporují rozvoj té či oné dovednosti, tyto programy pro žáky zajistit a metodicky i didakticky správně je naučit pracovat $\mathrm{s}$ nimi tak, aby postupně zlepšovali své znalosti a dovednosti. Právě individuální charakter speciálních vzdělávacích potřeb konkrétního žáka klade při praktickém používání digitálních technologií ve výuce velké nároky na odbornou přípravu pedagoga, protože jak počítačový hardware, tak i počítačové programy sice mohou být velmi výrazně zaměřeny na podporu či kompenzaci určitého deficitu, avšak při nevhodném použití mohou působit kontraproduktivně a konkrétnímu žákovi mohou i ublížit.

Typickým příkladem by mohlo být dlouhodobé a soustavné hraní akčních dobrodružných počítačových her nebo sledování multimediálních programů jedinci s poruchou ADHD jak v rámci vzdělávacích, tak i volnočasových aktivit. Tyto hry však obsahují některé nevhodné prvky:

- akční scény obsahující násilí (např. tzv. „stř́ilečky“), tj. nevhodný obsah z hlediska rozvoje sociálních dovedností,

- akční scény vyžadující rychlou aktivní reakci hráče, tj. požadavek, který je v rozporu se samotnou podstatou poruchy pozornosti ADHD, 
- více obtížnostních úrovní hry, které navazují jedna na druhou a které vyžadují dlouhodobé soustředění hráče, tj. opět požadavek, který jedinec s ADHD může jen obtížně splnit,

- hodnocení úspěšnosti hráče podle dlouze stupňované náročnosti plnění úkolů, které svým charakterem jedince s ADHD přímo znevýhodňují a jsou příčinou jeho neúspěchu ve hře.

To vše jsou rizikové faktory pro progresi poruchy ADHD, které rozvíjejí a zhoršují její symptomy a mohou vést $\mathrm{k}$ rozvoji sekundárních poruch, např. úzkostných poruch, depresí a nespavosti, které vznikají při chronickém přetížení vznikajícím při dlouhodobém a opakovaném hraní takového typu her. Je zřejmé, že takové rizikové prvky mohou obsahovat i jiné počítačové aplikace, někdy i zdánlivě neškodného a dokonce pro intaktního žáka i edukačně prospěšného charakteru, např. programy pro opakování a procvičování matematických dovedností nebo znalostí gramatiky. Naopak, správně použité digitální technologie $\mathrm{v}$ asistivní roli mohou redukovat potenciální spouštěče nežádoucího chování (Parette 2007). Je tedy na kvalifikovaném úsudku pedagoga, případně rodiče nebo poradenského pracovníka, zda a jakým způsobem umožní takovou aplikaci žáku s ADHD využívat, resp. jak upraví její konfiguraci a používání zpơsobem, který by poruchu ADHD neprohluboval a dále nerozvíjel.

Současně je zřejmé, že takové rozhodování klade velké nároky na pedagoga v inkluzivní škole, a to jak po stránce jeho speciálně pedagogických kompetencí (v našem konkrétním případě se zaměřením na ADHD) a všeobecných pedagogických kompetencí, tak i po stránce jeho specializovaných digitálních kompetencí. Pedagog musí volit vhodné digitální technologie a zejména vzdělávací aplikace z velké, stále se inovující a rozšiřující se nabídky dostupné jak prostřednictvím školských distribučních kanálů, tak zejména přístupné online pomocí internetu. Musí při tom zohledňovat charakter speciální vzdělávací potřeby žáka a samozřejmě obecné edukační cíle a konkrétní podmínky použití ve své škole s ohledem na její vybavenost 
digitálními technologiemi. Zvolené aplikace musí pedagog účelně a smysluplně použít v konkrétní pedagogické situaci k dosažení stanovených vzdělávacích cílů a samozřejmě by měl být schopen provést hodnocení dosažených výsledků.

Ve své práci se pedagog obvykle může opřít o poznatky publikované v odborné literatuře. Při rešerši provedené při přípravě této kapitoly však bylo zjištěno, že počet prací zaměřených konkrétně na hodnocení působení digitálních technologií na žáky s ADHD je překvapivě malý, a to i přesto, že samotná problematika ADHD stejně jako samotná problematika digitálních technologií patří mezi intenzivně studované a progresivní obory. Souvisí to pravděpodobně s velkou specializovaností a zároveň výraznou odlišností obou oborů - odborné studie zaměřené na využití digitálních technologií ve vzdělávání př́iliš nereflektují specifika žáků se speciálními vzdělávacími potřebami a podobně vzácné jsou speciálně pedagogické výzkumy zaměřené na využívání digitálních technologií při edukaci žáků se SVP. Mnoho prací se omezuje na všeobecné vágní konstatování o vhodnosti používání počítačových programů při vzdělávání žáků s poruchami učení a/nebo s ADHD, konkrétní příklady a zkušenosti však obvykle nejsou uváděny. Problematika edukace a reedukace žáka s poruchou ADHD je již natolik specializovaný obor, že odborné studie zaměřené na využití digitálních technologií u žáků s ADHD lze v celosvětovém měřítku nalézt jen výjimečně (viz např. databáze ProQuest, vyhledávače Google Scholar aj.), a pokud existují, jen málokdy reflektují také aktuální stav vývoje digitálních technologií.

\section{Pozitivní a rizikové faktory}

Ukazuje se, že použití vhodných výukových programů vede u žáků $\mathrm{s} A \mathrm{DHD}$ ke zlepšení čtenářských a početních dovedností (plynulost čtení a počítání) a následně ke zlepšení hodnocení těchto žáků učiteli. Více průkazná jsou zlepšení v určitých oblastech, jako je např. doba čtení nebo soustředění, v některých oblastech je zlepšení 
menší, nap̌r. čtení s porozuměním (DuPaul 2012). Hecker realizoval v USA výzkum u adolescentů a zjistil, že při využití asistivních digitálních technologií se výrazně zlepšily čtenářské skóry respondentů s poruchou pozornosti. Konkrétně se jednalo o použití programu umožňujícího převod textu do hlasové podoby a jeho následnou synchronizaci s vizuální podobou. Byl prokázán $54 \%$ nárůst v počtu stránek přečtených za minutu, $29 \%$ pokles doby potřebné k přečtení zadané pasáže textu, 50\% pokles počtu přerušení čtení a $65 \%$ nárůst míry soustředění před přestávkou. Výrazná většina respondentů uvedla (celých 80 \%), že čtení s pomocí takového programu bylo pro ně méně stresující (Hecker 2002 in Sexton 2012). Tyto závěry lze zjevně aplikovat i u nižších věkových skupin, např. u žáků 2 . stupně základní školy.

Často se zdůrazňuje aspekt komplexnosti terapie, která v přiměřené míře zahrnuje všechny dílčí způsoby intervence včetně medikace a reedukačních intervencí zahrnující také používání počítačů. Akcentovány jsou přitom intervence směřující proti příčinám poruchy - příkladem může být rukopisné psaní. Je-li prríčinou problémů s psaním porucha jemné motoriky, je zapotřebí preferovat bud'to cvičení ke zlepšení jemné motoriky nebo volit kompenzační strategii např. psaní pomocí počítače. Nelze se omezovat na pouhé procvičování rukopisného psaní, které samotné nevede k očekávanému zlepšení. Jestliže mají problémy s psaním jinou, sekundární příčinu, je nezbytné ji nejprve identifikovat a odstranit. Z klinického hlediska je tedy zapotřebí rozlišovat ty případy, kdy jsou poruchy motoriky způsobeny spíše tzv. energetickými faktory (kognitivně energetického modelu deficitů ADHD) a případy, kdy je motorika postižena na hlubší neurofyziologické úrovni. V prvním případě může medikace stimulancii zmírnit projevy poruchy (Stray, Stray, Iversen, Ruud, \& Ellertsen 2009 in Egeland 2011), ve druhém případě musí intervence směřovat proti nárokům na jemnou motoriku potřebnou ke zvládnutí daného 
úkolu, např. použitím počítače ke psaní nebo procvičováním motoriky (Watemberg et al., 2007 in Egeland 2011).

Carlsonová (2002) se zabývala problematikou motivace žáků s ADHD a využitím tzv. incentivní (pobídkové) terapie. Uvádí, že oba subtypy žáků s ADHD vykazovaly malou vnitřní motivaci pro učení se teoretickým znalostem a dovednostem (academic skills) a v případech, kdy je vnitřní motivace žáků slabá nebo vůbec chybí, považuje za nezbytné doplnit ji, resp. nahradit motivací vnější. Vychází ze svých výzkumů, které prokazují pozitivní účinek motivujících pobídek na výsledky žáků s ADHD při řešení kognitivních úkolů a současně uvádí, že takové vnější pobídky nesnižují jejich vnitřní motivaci a případný zájem.

Přípravou učitelů pro vzdělávání žáků s ADHD se zabýval tým Jordanové. Navrhli a ověřili distanční e-learningové kurzy, které měly za cíl zlepšit znalosti a porozumění pedagogů v problematice poruchy ADHD prostřednictvím vyspělé digitální technologie internetového kurzu. Z publikovaných závěrů vyplývá, že tato forma vzdělávání skutečně zlepšila informovanost respondentů o problematice $\mathrm{ADD} / \mathrm{ADHD}$ a navíc si respondenti procvičili používání vybraných digitálních technologií (Jordan 2004).

Pozitivní výsledky v oblasti využití digitálních technologií ve vzdělávání žáků s ADHD potvrzuje také Xu (2002), a to zejména v oblastech počítačem podporovaného vzdělávání, počítačem podporovaného tréninku kognitivních funkcí včetně on-line forem, hodnocení žáků pomocí digitálních technologií a při nápravě poruch chování, zejména $\mathrm{v}$ souvislosti s použitím biofeedbacku a vhodných počítačových her.

Výzkumy zaměřené na negativní vlivy digitálních technologií prokazují nadměrné používání počítače a internetu (netolismus) jako rizikový faktor prohlubující projevy ADHD. Chan (2006) uvádí, že u adolescentů, kteří každodenně hráli internetové videohry, se intenzivněji projevuje porucha ADHD nebo ADD než u těch, kteř́i hry nehráli. 
Neuvádí však, jaký typ her respondenti hráli a zda projevy poruchy lze dát do souvislosti se samotným hraním her či zda projevy poruchy ovlivňuje také obsah a charakter hry. Současně Chan poukazuje na možné negativní důsledky internetového hraní na školní úspěšnost.

Podobné závěry učinil Yoo (2004), který zjistil signifikantní spojitost mezi intenzitou projevů symptomů ADHD a stupněm závislosti na internetu. Spojitost byla obousměrná, skupina osob závislých na internetu vykazovala silnější projevy poruchy ADHD a naopak, ve skupině respondentů s ADHD byla zjištěna vyšší prevalence závislosti na internetu. Yoo konstatuje, že symptomy ADHD, a to jak poruchy pozornosti, tak i hyperaktivita, mohou být rizikovými faktory při vzniku závislosti na Internetu.

\section{V návaznosti na komorbiditu poruchy ADHD a specifických} poruch učení nelze opomenout také využití digitálních technologií pro žáky se SPU. Podle Lopúchové se má jejich používání zaměřit zejména na rozvoj pozornosti, postupné plnění dílčích úkolů, orientaci na ploše, pravolevou orientaci, zrakové a sluchové vnímání, diferenciaci vjemů a jejich spojování, rozvoj řeči a rozvoj paměti (Lopúchová, Krajčí 2014). Digitální technologie také umožňují změnu druhu činnosti (práce $\mathrm{s}$ tištěnou pomůckou $\times$ práce s počítačem), posilují motivaci, jestliže s nimi žák může pracovat za odměnu a lze je využít také při relaxačních a odpočinkových aktivitách.

Krajčí uvádí následující konkrétní možnosti využití digitálních technologií pro reedukaci specifických poruch učení:

- dyslexie - programy pro rozvoj, prohlubování a korekce techniky čtení, různé techniky čtení, rozpoznávání tvarů písmen, čtení a spojování hlásek do slabik a následně do slov, rozvoj automatizace techniky čtení, porozumění čtenému textu a poskytování zpětné vazby, 
- dysgrafie - programy pro zápis textů jako alternativa zápisu do sešitu; rozpoznávání, osvojování a rozvoj psaní tvarů písmen, orientace na ploše, psaní podle diktátu,

- dysortografie - programy pro prohlubování, procvičování a upevňování gramatických pravidel, rozlišování tvrdých a měkkých souhlásek, rozlišování začátku a konce slova aj.

- dyskalkulie - programy pro třídění a rozlišování předmětů a tvarů podle kritérií, rozvoj pravolevé orientace, uspořádání předmětů podle vlastnosti, osvojování a procvičování psaní a čtení číslic, procvičování a automatizace základních matematických operací aj. (Krajčí 2014).

Výše uvedené př́íklady svědčí o tom, že digitální technologie lze s výhodou využít také při nápravě specifických poruch učení. V případě žáka se souběhem ADHD a SPU je však třeba vyvarovat se určitých aplikací, resp. takových způsobů použití digitálních technologií, který by mohly projevy ADHD zhoršovat i přesto, že při nápravě SPU přinášejí pozitivní výsledky. Současně by bylo žádoucí, aby byly výčty takových kontraindikací uváděny v dokumentaci počítačových programů určených zejména žákům se speciálními vzdělávacími potřebami tak, aby pedagogům i rodičům poskytovaly vodítko ke správnému použití.

\section{Přínos digitálních technologií pro vzdělávání žáků s ADHD}

V literatuře lze nalézt mnoho argumentů, proč používat digitální technologie ve vzdělávání. Pozitivní př́inosy digitálních technologií předpokládají, že učitelé mají potřebné pedagogické i digitální kompetence, mají k dispozici vhodné učební materiály v digitální podobě a samozřejmě také adekvátní technické vybavení. Současně je třeba poznamenat, že platnost uvedených argumentů nelze generalizovat, vždy se najdou výjimky.

V obecné rovině lze konstatovat, že pro používání digitálních technologií pro žáky s ADHD platí analogická doporučení, pravidla a meto- 
dické zásady jako pro intaktní žáky. Dále je třeba respektovat všechna pravidla a zásady specifická pro práci se žáky s ADHD, která jsou uvedena $\mathrm{v}$ jiných částech této knihy, např. používat vhodnou motivaci spojenou se systémem odměn nebo jednoduše přizpo̊sobovat pracovní úkoly formou zkrácení rozsahu úkolu, rozdělení úkolu na více samostatných částí a případně prodloužení doby pro splnění.

Všeobecně se však zdá, že mezi většinové pozitivní důvody používání počítačů, tabletů, chytrých telefonů, interaktivních tabulí, internetu, digitálních vzdělávacích materiálů a dalších digitálních technologií lze zařadit následující:

1. Žáci rádi používají počítače, práce s nimi je baví. Nenásilné prokládání výuky aktivitami s počítačem je dobrá motivace. Výsledkem využívání digitálních technologií je často produkt (text, grafika, videosekvence, ale také hodnocení žáka), který lze sdílet s ostatními ve škole i mimo ni. To podporuje přirozenou soutěživost žáků a také přispívá $\mathrm{k}$ lepšímu informování rodičů o školních aktivitách svých dětí.

2. Činnosti s počítačem zapojují do učení všechny žáky, vytvářejí vhodné prostředí pro skupinovou práci stejně jako pro individuální aktivity. Odpovědní (hlasovací) systémy umožňují rychlou zpětnou vazbu a při vhodném použití umožňují i slabším a pomalejším žákům uplatnit se a zažít úspěch.

3. Digitální technologie jsou nezbytnou součástí profesního rozvoje a digitální kompetence zlepšují budoucí možnosti uplatnění na trhu práce.

4. Digitální technologie zprostředkovávají žákům autentičtější informace, zejména v případech, které si žáci jen obtížně umí představit. Pozorování je v mnoha oborech zdrojem poznání a mnoho dějů nelze demonstrovat přímo ve vyučování. Multimédia a animace slouží k lepšímu pochopení učiva. 
5. Digitální technologie pomáhají pedagogům při hodnocení žáků (on-line testy), při přípravě a opakovaném použití digitálních učebních materiálů, při vedení pedagogické dokumentace a další školní administrativy.

6. Digitální technologie zlepšují výsledky žáků. Toto tvrzení je sice často rozporováno, ale ukazuje se, že je zpochybňováno zejména $v$ těch případech, kdy nejsou splněny předpoklady jejich používání. Obecným východiskem je, že motivovaní žáci, kteří používají oblíbené pomůcky a mají podmínky pro to „učit se rádi“" dosáhnou lepších výsledků než ti, kteří se učí neradi.

7. Digitální technologie umožňují přizpůsobit tempo učení potřebám a možnostem jednotlivých žáků, což má velký význam zejména pro žáky se speciálními vzdělávacími potřebami. K možnostem přizpůsobení tempa výuky patří také to, že si žáci mohou výklad učiva zopakovat doma z videonávodu či jiných on-line přístupných učebních materiáli̊, což je vhodné zejména $v$ těch případech, kdy žáci učivo dostatečně nepochopili přímo ve škole nebo chyběli ve výuce např. $\mathrm{z}$ důvodu nemoci.

8. Digitální technologie odstraňují překážky. Každý žák je jedinečnou osobností a jeho individuální potřeby pro optimální učení se často mohou lišit od potřeb ostatních. Toto pravidlo platí pro žáky se speciálními vzdělávacími potřebami stejně jako pro žáky intaktní. Text psaný na tabuli nebo promítaný na projektoru lze zobrazit také na displeji žákova tabletu tak, aby ho žák mohl bezchybně přečíst. Dobrý poslech není předpokladem jen jazykové výuky.

9. Digitální technologie kompenzují některé specifické deficity žáků se speciálními vzdělávacími potřebami a tím výrazně podporují jejich inkluzivní vzdělávání. Vhodné digitální technologie lze s výhodou použít jako kompenzační pomůcku při inkluzivním vzdělávání. 
10. Digitální technologie přes vyšší počáteční náklady ve svém důsledku šetří peníze, připravené učební materiály lze použít opakovaně a roste také množství volně dostupných vzdělávacích materiálů (Open Educational Resoureces OER) vhodných pro děti se SVP.

Mezi výše uvedenými argumenty není zřejmě žádný, který by neplatil také pro používání digitálních technologií ve vzdělávání žáků s ADHD.

Nad uvedený rámec lze doporučit např. ochranné obaly s pružným povrchem pro tablety a počítače, které ocení žáci s hyperaktivitou i jejich rodiče. Další praktická doporučení a inspirace publikovaná v českém jazyce směřující jmenovitě k využití digitálních technologií ve vzdělávání žáků s ADHD, př́ípadně žáků, u kterých se ADHD kombinuje s jinou poruchou, lze nalézt nap̌r. na we-

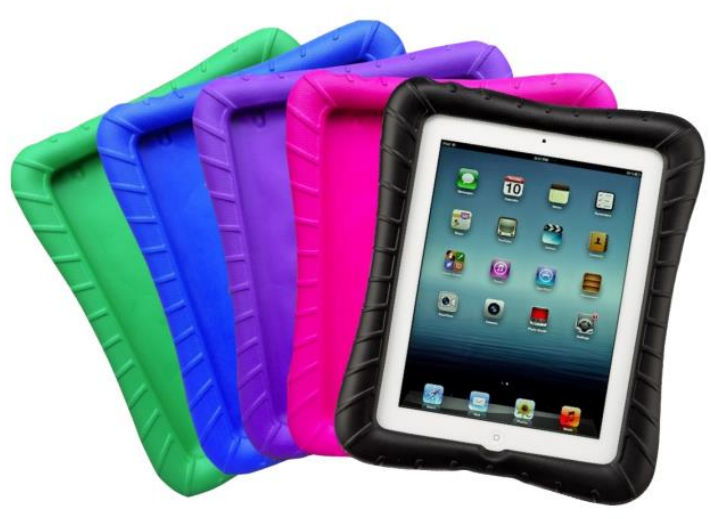
bech i-Sen (http://www.i-sen.cz/) nebo http://www.adehade.cz/.

Zcela nezbytně je však třeba respektovat specifika poruchy ADHD a přidat další podmínku: učitel i žák musí používat digitální technologie způsobem, který vyrovnává deficity způsobené poruchou ADHD a nezhoršuje jejich projevy. 
Determinanty inkluzivního vzdèláváni dětí s ADHD 


\section{Osobnost učitele v procesu inkluzivní edukace}

Za inkluzivní edukaci považujeme takový systém vzdělávání, který umožňuje všem dětem bez rozdílu navštěvovat běžnou základní školu. Učitelé v inkluzivních školách přistupují ke každému žákovi individuálně a na individuálním přístupu je postavena nejen výuka, ale i celá organizace školy. Každé dítě má svůj vzdělávací plán, který se přizpo̊sobuje jeho schopnostem, nadání, obtížím. Výuka v inkluzivních školách se soustřed’uje zejména na to, aby každé dítě plně využilo svůj rozumový potenciál a zároveň se naučilo komunikovat a spolupracovat s ostatními. Odlišnost dětí se považuje za př́ležitost $\mathrm{k}$ rozvoji respektu, empatie, tolerance, ohleduplnosti a zodpovědnosti k sobě i ostatním.

Učitel by měl být proto informován o specifikách vývoje dětí s určitým druhem postižení, v našem konkrétním případě o $\mathrm{ADHD}$, a o metodice jejich výuky, důležitá je také jeho spolupráce s rodiči. Měl by být schopen vytvořit příznivé klima ve třídě, opatřit pro dítě kompenzační pomůcky a vzhledem $\mathrm{k}$ tomu, že většina učitelů běžných škol nemá speciálně pedagogické vzdělání, spolupracovat se speciálně pedagogickým centrem (Keblová 1996). Individualizovaná práce, projektová výuka, vrstevnické vyučování, učení se na příbězích, e-learning a mnoho dalších metod přispívá $\mathrm{k}$ širokému rozvoji komunikativnosti dětí, k lepšímu vnímání odlišnosti, k rozvoji samostatné i týmové práce a v neposlední řadě k citlivějšímu vnímání chování žáků.

Humphrey ve svém článku věnovaném pedagogické inkluzi konkrétně žáků s ADHD a SPU uvádí Cooperův názor, že užitečné strategie na podporu rozvoje pozitivní inkluzivní praxe pro žáky se specifickými poruchami učení a ADHD ve školním prostředí musí pro učitele znamenat naučit se změnit pohled na vnímání obsahu termínu těchto poruch. Především navrhuje, aby na uváděné deficity bylo pohlí- 
ženo nikoliv jako na deficity, ale zejména jako na odlišný kognitivní styl jejich nositelů. Důsledkem takového přístupu dle jeho názoru bude snaha učitelů rozvíjet takové pedagogické strategie, které využijí společné charakteristiky těchto žáků se žáky bez uváděných deficitı̊. Nebudou se především zaměřovat na jejich odlišnosti. Tím dojde $\mathrm{k}$ přirozené psychické podpoře všech žáků bez rozdílu. Pokud učitel např. dokáže alespoň částečně saturovat potřebu emočního přijetí dítěte s uvedenou diagnózou přesto, že trpí např́íklad reaktivně podmíněnými emočními problémy v závislosti na dlouhodobou výkonnostní zátěž ve škole a zvládne realizovat nekonfliktní komunikaci s jeho rodiči, jedná se dle našeho názoru o naplnění důležitých psychologických aspektů v individuálním př́istupu k žákovi s ADHD (Cooper 2005 cit. dle Humphrey 2009).

Učitel je právě tím, kdo odpovídá za to, co se žák ve škole naučí, zároveň tím, kdo rozhoduje, jak bude hodnocen. Žáci s ADHD jsou často $\mathrm{v}$ řeči učitelů označováni za žáky problémové. Péče o ně je logicky zatěžující a ještě $\mathrm{k}$ tomu vynaložené úsilí pedagoga nebývá zcela naplněno.

Podle Pedagogického slovníku je učitel: „Jeden ze základních činitelů vzdělávacího procesu, profesionálně kvalifikovaný pedagogický pracovník, spoluzodpovědný za prípravu, ř́zení, organizaci a výsledky tohoto procesu“ (Průcha, Walterová, Mareš 2005, s. 261).

Předpoklady pro výkon činnosti učitelů a jiných pedagogických pracovníků stanoví platná legislativa - aktuálně:

- zákon č. 563/2004 Sb., o pedagogických pracovnících, ve znění pozdějších předpisů (poslední novelizace zákonem č. 197/2014 Sb.),

- vyhláška MŠMT ČR č. 317/2005 Sb., o dalším vzdělávání pedagogických pracovníků, ve znění pozdějších předpisů (poslední novelizace vyhláškou MŠMT ČR č. 272/2014 Sb.), upravující možnosti alternativního získání pedagogické kvalifikace formou tzv. dalšího vzdělávání pedagogických pracovníků. 
Způsoby dosažení odborné kvalifikace učitele pro výkon přímé pedagogické činnosti na konkrétním druhu a stupni školy uvedené ve výše zmíněných právních předpisech lze zhruba rozdělit do následujících alternativ:

- vysokoškolské vzdělání získané studiem v akreditovaném magisterském studijním programu v oblasti pedagogických věd zaměřené na přípravu učitelů pro školy daného druhu a stupně,

- vysokoškolské vzdělání získané studiem v akreditovaném magisterském studijním programu v oblasti pedagogických věd zaměřené na přípravu učitelů pro školy jiného druhu a stupně doplněné dalším studiem (program celoživotního vzdělávání, doplňující studium k rozšířrení odborné kvalifikace aj.) zaměřeným na př́ípravu učitelů pro školy daného druhu a stupně,

- vysokoškolské vzdělání získané studiem v akreditovaném magisterském nepedagogickém studijním programu doplněné dalším studiem (program celoživotního vzdělávání, doplňující studium k rozšíření odborné kvalifikace aj.) zaměřeným na přípravu učitelo̊ pro školy daného druhu a stupně,

- učitelé mateřské školy mohou získat odbornou kvalifikaci také studiem na vyšší odborné škole nebo střední škole s maturitou zaměřené na přípravu učitelů mateřské školy,

- v případě školy nebo tř́ídy zřízené pro žáky se speciálními vzdělávacími potřebami:

- vysokoškolské vzdělání $\mathrm{v}$ akreditovaném magisterském studijním programu v oblasti pedagogických věd zaměřené na speciální pedagogiku pro učitele,

○ vysokoškolské vzdělání v akreditovaném magisterském studijním programu v oblasti pedagogických věd zaměřené na speciální pedagogiku doplněné dalším studiem (program celoživotního vzdělávání, doplňující studium k rozšíření odborné kvalifikace aj.) zaměřeným na přípravu učitelů pro školy daného druhu a stupně,

- vysokoškolské vzdělání získané studiem v akreditovaném magisterském studijním programu voblasti pedagogic- 
kých věd zaměřené na přípravu učitelů pro školy daného druhu a stupně doplněné dalším studiem (program celoživotního vzdělávání, doplňující studium k rozšíření odborné kvalifikace aj.) zaměřeným na speciální pedagogiku.

V případě konkrétního studijního programu je však vždy třeba zjistit, do které skupiny je studijní program podle své akreditace zařazen a pro výkon jaké prrímé pedagogické práce své absolventy připravuje, nebot ustanovení o uznávaných variantách možných studijních programů a způsobech jejich kombinování jsou často upravována a novelizována. Legislativa také stanoví, že v některých případech může další vzdělávání (program celoživotního vzdělávání, doplňující studium k rozšíření odborné kvalifikace aj.) poskytovat jen vysoká škola a obvykle stanoví také minimální hodinový rozsah takového studia a způsob jeho zakončení.

K volbě učitelského povolání mají lidé různou motivaci. Pohnutky pro vyslovení přání být učitelem mohou být rozmanité, od citově zabarvených, přes nahodilé až po jasné, rozumově uvážené a zdůvodněné. Z osobní zkušenosti nezbývá než konstatovat, že vysoký zájem o studium na pedagogické fakultě je zavádějící. Mnoho zájemců o studium podává přihlášku na pedagogickou fakultu pouze jako pojistku pro případ, že nebudou přijati na jimi preferovanější fakultu a obor. Vzhledem k mimořádné náročnosti učitelského povolání na psychiku by bylo vhodné zvažovat při výběru učitelů i jejich zdravotnicko-psychologické aspekty osobnosti. V současné době se při studiu osobnosti učitele uplatňují zejména dva př́ístupy, normativní a analytický.

Cílem normativního přístupu je určit, jaký má být učitel, pokud chce mít ve výchovně-vzdělávací práci úspěch. Hovoříme o dvojí kvalifikaci učitele: odborné a pedagogicko-psychologické. Žáci a studenti oceňují zejména učitele tzv. sociálního a filantropického typu. Ti jsou schopni systematicky trpělivě vytvářet pozitivní klima v celé škole i v jednotlivých třídách, upřednostňují dialog v komunikaci se žáky, nepostrádají humor ani životní optimismus. 
Mezi žáky a studenty nejsou naopak oblíbeni netrpěliví učitelé cholerického a extrémně autoritářského typu, kteří žáky a studenty ironizují, často okřikují a někdy dokonce i fyzicky trestají. Nelibě reagují žáci a studenti na preferování oblíbenců učitelů a učitelek. Z druhé strany pro svého oblíbeného učitele žáci dokáží zvýšit svou aktivitu a pracovní úsilí nejen ve školním prostředí, ale i v rámci domácí př́ípravy.

Vašutová se zabývá jedinci, kteří se stanou učiteli proti své vůli. Uvádí, že pokud se těmto učitelům nepodaří překonat vnitřní bariéry, vnášejí do své práce lhostejnost a negativismus, popřípadě mohou utrpět i šok z prostředí školy (Vašutová 2004).

Po ukončení studia se někteří absolventi skutečně hlásí o zaměstnání ve vystudovaném oboru. U začínajících učitelů se v současné době setkáváme se dvěma extrémy. Mnozí začínající učitelé se obávají, že nezvládnou každodenní náročnou práci učitele. Nemají dostatečnou jistotu, zda úspěšně uchopí vzdělávání svěřených žáků.

Ovšem někteří začátečníci jsou naopak přesvědčeni, že jsou dobrými a zcela „hotovými“ učiteli, a tak je nemůže žádná situace zaskočit. Bývají rezistentní k jakékoliv podpoře ze strany zkušenějších kolegů. Přitom typickým problémem začínajících učitelů je schopnost navázat odpovídající kontakt se žáky a získat si jejich důvěru a přízeň. Často také obsahově předimenzují vyučovací hodinu, takže její obsah jsou schopni absorbovat pouze bezproblémoví žáci. Jejich úsilí vyložit co nejvíce učiva se dostává do rozporu s uplatněním časově náročných aktivizujících metod použitých ve vyučování a schopností udržet kázeň žactva.

Začínající učitelé také většinou nedokáží adekvátně své žáky hodnotit. Často mívají neúměrné nároky na jejich výkon a neberou v potaz jejich skutečné možnosti. Někteří začátečníci se naopak obávají, aby žáky př́liš nepřetěžovali, a mají neúměrně nízké nestimulující nároky. Typickou začátečnickou obtíží je dovednost získat si respekt ve třídě, v učitelském sboru i u rodičů svých žáků. Mnohdy začínající učitelé nechápou, že skutečně trvá určitou dobu, než se jim to podaří... 
Po nějaké době se ze začínajícího učitele stává slovy J. Průchy učitel expert (Průcha 2005), neboli zkušený učitel. Nelze ovšem přesně vymezit, po jak dlouhé době od vstupu do profese to bývá. Většinou se hovoří o úseku následujícím po pěti letech práce v oboru. Právě v této fázi učitelé nejvíce ovlivňují charakter edukačního procesu ve školním prostředí, nebot působí nejen na žáky, ale i jako vzor pro začínající učitele.

Období, kdy učitel začíná být „zkušeny““ je hranicí, za kterou již není nutno mu poskytovat soustavnou odbornou pomoc ve smyslu uvádění do praxe. $\mathrm{V}$ tomto období by měl mít především možnost účastnit se některé formy dalšího vzdělávání.

Důležitější než otázka časové periodizace profesní dráhy učitelů je otázka, jakými vlastnostmi má disponovat zkušený učitel. Rozsáhlejší nároky na něj kladené se označují jako kompetence, zahrnující soubor profesních dovedností a dispozic, kterými má být vybaven učitel, aby mohl efektivně vykonávat své povolání (Průcha, Walterová, Mareš 2005, s. 103).

Spilková uvádí tyto kompetence učitele:

1. Kompetence odborně předmětové.

2. Kompetence psychodidaktické - kompetence k vytváření příznivých podmínek pro učení, k motivaci k poznávání, k aktivizaci myšlení, k utváření vhodného pracovního i sociální klimatu atd.

3. Kompetence komunikativní - kompetence ke komunikaci nejen se žáky, ale i s dospělými jako jsou kolegové, nadřízení, rodiče žáků apod.

4. Kompetence organizační a řídící - kompetence ve vztahu k výuce, ale i ve vztahu k plánování a projektování vlastní pracovní činnosti.

5. Kompetence diagnostické a intervenční - kompetence k porozumění tomu, jak žák myslí, cítí, jedná, proč tomu tak je, jaké 
to má důvody, kompetence k rozpoznání toho, zda má žák nějaké problémy, jak mu pomoci apod.

6. Kompetence poradenské a konzultativní - kompetence ve vztahu k žákům, ale i ve vztahu k rodičům.

7. Kompetence reflexe vlastní činnosti - kompetence $\mathrm{k}$ analýze vlastní činnosti a k vyvození patřičných důsledků. (Spilková 2005)

Zejména u starších učitelů se setkáváme s projevy vyčerpání psychických sil, apatičností a skeptickým přístupem ke změnám. Běžně se o těchto stavech hovoří jako o únavě z dětí a ze školy vưbec (Kalhoust, Obst a kol. 2002).

Gillernová (2003) uvádí čtyři základní kategorie profesních kompetencí učitele, které zahrnují množství dílčích schopností a dovedností a vzájemně se velice často překrývají:

- Odborné dovednosti vycházejí především ze znalostí oboru, který učitel vyučuje.

- Didaktické zahrnují dovednost organizovat výuku a předávat znalosti a dovednosti svého oboru žákům a studentům v takovém rozsahu a kvalitě, aby jim dokázali porozumět a adekvátně je využít. Například Cangelosi opět poukázal, jak úzce je kvalitní způsob výkladu a schopnost jeho přizpůsobení všem žákům dle jejich potřeb spjat se sociálními dovednostmi učitele. Přestože existuje množství přístupů $\mathrm{k}$ výuce, všechny opakovaně se shodují v důrazu na různé složky verbální i neverbální komunikace (mj. schopnost pojmenovat své chování, pocity i myšlenky, př́ijem informací a podnětů od studentů), reflektování dění ve třídě, ocenění studentů a poskytnutí pomoci, stanovení pravidel a jejich důsledné dodržování (Cangelosi 1994).

- Prostřednictvím diagnostických dovedností učitel zvládá průběžně hodnotit své žáky, reflektovat jejich vývoj v rámci vzdělávání, odhadovat jejich učební styl či potenciál dalšího vzdělávání. V souladu s teorií Vygotského $(1976,2004)$ by měl 
dokázat určit jejich zónu nejbližšího vývoje a jejím možnostem a kapacitám přizpůsobit svůj styl výuky.

- Sociálně psychologické, případně speciálně pedagogické dovednosti, umožňují učiteli jednak adekvátně vystupovat v interakcích se všemi účastníky edukačního procesu (tj. žáky, studenty, svými kolegy, nadřízenými, rodiči žáků a studentů, externími institucemi, které se podílejí na chodu školy), jednak přizpůsobovat své pedagogické působení speciálním potřebám svých žáků.

Fontana (2010) je toho názoru, že učitelství je svou povahou stresovým zaměstnáním. Pedagogové jsou neustále vystaveni požadavku udržet ve třídě kázeň, mnoho své práce si nosí domů a mají tak omezenou možnost odpočinku, jsou neustále vystaveni kritice inspektorů, ředitelů, rodičů, ale i sdělovacích prostředků. Nemají dostatek prostředků a příležitostí $\mathrm{k}$ dalšímu pravidelnému vzdělávání. Přitom všem se od nich očekává, že budou držet krok s novými osnovami, určitou měrou se podílet na řízení školy a na přijímaných rozhodnutích. Kromě toho bývají emočně zaangažováni na úspěších, ale i na selháních svých žáků. Mnozí jsou výrazně ovlivněni snahou o udržení profesionální úrovně v měnící se společnosti a pocity frustrace, že jí plně nedosahují.

V každodenní praxi má učitel mizivou příležitost k získání opory zvenčí. Celý den pracuje s dětmi v relativní izolaci od ostatních dospělých, a tudíž má omezenou možnost pohovořit si s kolegy či je požádat o radu. Vyrovnat se se stresem může člověku pomoci podpora a povzbuzení od lidí plnících stejné či podobné úkoly a vzájemně chápajících své obtíže.

Náročným úkolem, který současné integrativně inkluzivní trendy na učitele kladou, souvisí s jeho každodenní podporou žáků se SVP včetně dětí s ADHD. Každý z pedagogů, který v procesu vzdělávání přijde do kontaktu s těmito žáky, by si měl být vědom, jak je důležité vytvořit si k nim adekvátní postoj bez extrémů. Měl by dokázat akceptovat dítě takové, jaké je a nesnažit se vlivem soucitu snižovat na něj náro- 
ky a nevystavovat ho žádným požadavkům. Pokud nevidí výsledky své práce, neměl by žáka zavrhovat, ale měl by se pokusit pro něj vytvořit systém podpůrných opatření.

Profesionalismus učitele spočívá ve schopnosti odhadnout skutečné možnosti žáka a stanovit přiměřené požadavky odpovídající jeho skutečným schopnostem. Učitel si dále musí být vědom, že se nemůže obejít bez spolupráce s rodiči žáka, i když mnohdy je ona spolupráce skutečně náročná až vyčerpávající. Pokud všechny tyto požadavky splní, je schopen dítěti pomoci a zvýší pravděpodobnost jeho úspěšné integrace.

Na učiteli tedy závisí, jaké smýšlení o sobě dítě bude mít. Co si bude myslet, že dokáže, jakou získá míru sebedůvěry, do jaké míry bude motivováno usilovat o dosažení lepších výsledků. Ovlivní i způsob, jakým žák bude chápat své postavení ve třídě tím, jaký význam bude přičítat jeho obtížím. Svým přístupem, hodnocením a prezentací žáka do určité míry ovlivní i jeho postavení mezi vrstevníky ve třídě. Základem adekvátního přístupu k žákům s SPU je získat dostatek vědomostí o dané poruše. Sami žáci považuji za nejdůležitější, aby jejich učitel byl citlivý a empatický. Jak podotýká Brooks, obě tyto vlastnosti jsou součástí sociální inteligence a pouhým studiem si je člověk neosvojí (Brooks 2001).

Učitel by měl být tím, kdo ovládá základy prevence, diagnostiky i intervence $\mathrm{v}$ práci $\mathrm{s}$ žáky $\mathrm{s}$ SPU, neměli by $\mathrm{mu}$ ovšem chybět spolupracovníci do týmu, školní psycholog a speciální pedagog jako konzultanti pro řešení výukových problémů i jako pomocníci v etapě př́ípravy, realizace a hodnocení výuky. Potřebuje nezbytně vnější podporu při své náročné práci.

Optimální učení u všech žáků včetně těch s ADHD nastává tehdy, když žák postupuje $v$ učivu dále až poté, kdy dobře zvládl předcházející krok (Michalová 2011). Více než padesát studií prokazuje, že pečlivé strukturování, monitorování a kontrolování učebního procesu zlepšuje učební výsledky žáků. Časté vyhodnocování výsledků učení poskytuje učitelům i žákům informace, které 
pasáže učiva potřebují znovu a případně jinak vysvětlit. Učitelé by měli používat takové hodnotící strategie, při nichž žáci dostávají objektivní zpětnou vazbu o svých výsledcích.

Mezi základní sociálně psychologické dovednosti učitele řadíme (Gillernová 1998):

- schopnost empatie vůči jednotlivci (žákovi) i skupině (školní třídě),

- odlišování prožitků a pocitů od úvah a úsudků u sebe i u žáků,

- otevřené vyjadřování pozitivních i negativních prožitků,

- umění pochválit,

- respekt vůči odlišnému názoru,

- naslouchání,

- orientace v neverbálních projevech interakce, autenticita,

- reagování na konkrétní situace a ne na zobecněné a zobecňující zkušenosti,

- akceptování osobnosti žáků, podporování sebekontroly žáků,

- rozvíjení odpovědnosti žáků,

- rozvíjení sebedůvěry žáků,

- rozvíjení sebejistého vystupování,

- vedení ke spolupráci, porozumění svému vlivu na žáky a vlivu žáků na učitele.

Kyriacou dospěl k následujícím skupinám klíčových dovedností učitele, které by rozhodně žádnému z nich, který danou profesi vykonává, neměly chybět:

- plánovací dovednosti,

- dovednosti realizační a řídící,

- dovednosti přispívající k vytváření a rozvíjení příznivého klimatu ve třídě,

- dovednosti nezbytné k udržení kázně,

- diagnostické dovednosti,

- autodiagnostické dovednosti (Kyriacou 1996, s. 25). 


\section{Determinanty ADHD - výzkumné šetření}

Děti v mateřských školách a následně také žáci základních škol tráví ve školním prostředí velkou část dne. Proto považujeme za velmi důležité, aby ve škole byly vytvářeny příznivé podmínky pro další rozvoj žáků tak, jak o tom hovoři školský zákon, konkrétně § 2 zákona 561/2004 Sb. v aktualizovaném znění novely 82/2015 Sb., tj. rovné podmínky pro všechny jedince, které současně zohledňují vzdělávací potřeby každého jednotlivce. Odpovídající znalosti o ADHD musí mít nezbytně všichni, kteří s dětmi s touto poruchou pracují, nebot výše uvedený zákon také ukládá zdokonalovat proces vzdělávání na základě výsledků dosažených ve vědě, výzkumu a vývoji a co nejšíře uplatňovat účinné moderní pedagogické př́ístupy a metody.

Dostatek informací a uvědomění si toho, jak ADHD žáka ovlivňuje a jak silně omezuje jeho schopnosti podávat požadovaný školní výkon, je pro efektivní práci s těmito dětmi nezbytný a významně determinuje edukační proces. Role učitelů je nesmírně důležitá nejen pro práci s dítětem s diagnostikovanou poruchou. Učitel může sehrát klíčovou úlohu i při primárním screeningu, tedy při prvotní identifikaci problémů projevujících se ve školním prostředí (Malá 2002; Michalová 2007). Učitel může dát návrh k vyšetření dítěte, má-li podezření, že se ona porucha u něj vyskytuje. Právě pedagogové často rodičům poskytují první informace o tom, jak s dítětem s ADHD pracovat a jak dále postupovat. Je tedy nesmírně důležité, aby učitelé měli dostatečné a správné znalosti o ADHD (Sciutto 2000a). Z hlediska př́pravy pedagogů pro inkluzivní vzdělávání žáků s ADHD je pak důležité identifikovat ty skupiny pedagogů, u kterých je úroveň teoretických vědomostí horší než u ostatních. Na tyto skupiny by se pak mělo primárně soustředit vzdělávání o problematice edukace žáků s ADHD, nebot očekáváme, že jeho př́ínos by zde mohl být nejvý- 
raznější. To bylo také východiskem pro následující formulaci základní hypotézy realizovaného výzkumu:

Hypotéza H0: Mezi pedagogy mateřských a základních škol lze nalézt takové skupiny, u kterých se teoretické vědomosti o vzdělávání žáků s ADHD statisticky významně liší.

Skupiny pedagogů jsou zde vymezeny např. vzděláním, pracovním zařazením, délkou pedagogické praxe, zkušenostmi se vzděláváním žáků s ADHD, sebehodnocením vlastních vědomostí o ADHD a případně dalšími faktory. Teoretické vědomosti pedagogů budou zjištovány pomocí vhodného výzkumného nástroje, který má potřebné psychometrické vlastnosti, zejména reliabilitu, validitu a stabilitu.

V této souvislosti jsme při výzkumu pracovali také s širšími determinanty inkluzivního vzdělávání, které odpovídají vymezení determinantů výuky jako činitelů, které přímo ovlivňují inkluzivní vyučovací proces a jeho výsledky:

- Determinant č. 1 - obecné znalosti učitelů o ADHD.

- Determinant č. 2 - znalosti učitelů o charakteristických symptomech ADHD a jejich povědomí o diagnostice ADHD.

- Determinant č. 3 - znalost učitelů o intervenci a terapii ADHD.

Skutečné znalosti učitelů působících v mateřských a základních školách v České republice o hyperkinetickém syndromu ADHD jsme v letech 2014 až 2015 zjištovali v rámci projektu Cesta k inkluzi: od segregace $k$ pozitivní diverzitě ve školství, reg. č. CZ.1.07/1.2.00/47.0008. Zjištovali jsme také, zda existují faktory, které by mohly významně ovlivnit aktuální znalosti učitelů o této poruše, případně, do jaké míry tyto faktory aktuální znalosti učitelů skutečně ovlivňují. Realizátorem projektu a př́jemcem podpory byla Univerzita Jana Evangelisty Purkyně v Ústí nad Labem, proto budeme provedený výzkum dále označovat jako UJEP 2014. 


\subsection{Výzkumné nástroje}

Česká odborná literatura se úrovní znalostí učitelů o problematice ADHD př́liš nezabývá. $V$ české odborné literatuře se nám nepodařilo nalézt výsledky výzkumu s danou tematikou s výjimkou několika kvalifikačních prací.

Podrobný přehled výzkumných nástrojů používaných při zjištování znalostí pedagogů o ADHD zpracoval Soroa (2013) ve stejnojmenné kapitole Review of Tools Used for Assessing Teachers' Level of Knowledge with Regards Attention Deficit Hyperactivity Disorder (ADHD), která je součástí rozsáhlejší studie Attention Deficit Hyperactivity Disorder in Children and Adolescents (Banerjee 2013). Mezi nejpoužívanější řadí Soroa Škálu znalostí o ADHD (The Knowledge of Attention Deficit Disorders Scale, dále jen KADDS) vypracovanou Sciuttem. Uvádí, že je to první nástroj svého druhu, jehož psychometrické vlastnosti byly stanoveny a publikovány. Považuje KADDS s jeho dobrou reliabilitou a postačující validitou za důležitý referenční nástroj také pro ty výzkumníky, kteří realizují obdobná výzkumná šetření a nechtějí použít škálu KADDS. Rozsáhlejší použití škály KADDS je uváděno ve španělské literatuře. KADDS byl ve Španělsku lokalizován včetně přizpůsobení specifikám sociokulturního prostředí. Dosažené výsledky včetně údajů $\mathrm{z}$ ověřování psychometrických vlastností pak přehledně uvádí Jarque Fernández (2007). Novější data z výzkumů, které realizovali pomocí nástroje KADDS ve svých zemích, uvádějí např. Guerra (2012) pro Jižní Texas, USA, Alkahtani (2013) pro Saúdskoarabské království a Muanprasart (2014) pro Thajské království.

Na základě výše uvedených závěrů jsme se rozhodli při zjištování vědomostí a postojů českých učitelů o ADHD také použít škálu KADDS, kterou jsme lokalizovali, verifikovali a připravili v tištěné i elektronické verzi. 


\subsubsection{Posuzovací škála KADDS}

Škála znalostí o ADHD KADDS je výzkumný nástroj určený ke zjištění vědomostí pedagogů o hyperkinetické poruše ADHD, který umožňuje identifikovat také určitá nepochopení souvisejících pojmů či skutečností (Sciuto 2000b). Obsahuje 36 položek - posuzovacích škál s alternativami ano - ne - nevím, přičemž správná odpověd’ je hodnocena jedním bodem (1 bod) a nesprávná odpověd' včetně alternativy nevím pak nula body (0 bodů). Absolutní KADDS skór (kvantitativní výsledek) respondenta je pak dán prostým součtem bodů získaných za jednotlivé položky a nabývá hodnot v rozmezí 0-36 bodů. Ukazuje se jako užitečné stanovit také relativní KADDS skór, tj. absolutní KADDS skór přepočítat do relativní škály, tj. do rozsahu 0-100 \% s tím, že 36 bodům absolutního KADDS skóru odpovídá 100 \% relativního $K A D D S$ skóru. Rozdělení položek s pozitivní odpovědí (ano) a negativní odpovědí (ne) je vyrovnané v poměru 18 : 18.

Položky jsou rozděleny do tř́i subškál:

- První subškála nazvaná Všeobecně o ADHD obsahuje celkem 15 položek a mapuje obecné znalosti o povaze a př́ćinách $\mathrm{ADHD}$, nap̌r. ADHD se vyskytuje asi u $15 \%$ dětí školního věku nebo $A D H D$ se u děti školního věku vyskytuje stejně často u divek i u chlapců. Tato subškála koresponduje s výše stanoveným determinantem č. 1 .

- Druhá subškála Symptomy \& diagnostika obsahuje celkem 9 položek zaměřených na příznaky ADHD, např. Děti s ADHD maji často potǐže sorganizaci a plněním svých úkoli̊ a povinností nebo Děti s ADHD často kradou a niči věci ostatních. Tato subškála koresponduje s výše stanoveným determinantem č. 2 .

- Třetí subškála Intervence \& terapie obsahuje celkem 12 položek zaměřených na vědomosti o léčbě $\mathrm{ADHD}$, např. Stimulancia (napr. Ritalin) užívaná při léčbě ADHD mohou mít vedlejši účinky, napřr. nespavost či nechutenství nebo Diety 
somezením cukru a potravinových aditiv jsou pri redukci symptomů $A D H D$ účinné. Tato subškála koresponduje s výše stanoveným determinantem č. 3.

Rozdělení položek škály KADDS do jednotlivých subškál je uvedeno $\mathrm{v}$ tabulce 5 .

Tabulka 5: Rozdělení položek škály KADDS do subškál

\begin{tabular}{|l|l|c|}
\hline & \multicolumn{2}{|c|}{ Rozdělení položek KADDS do subškál } \\
\hline \multicolumn{1}{|c|}{ Subškála } & \multicolumn{1}{|c|}{ Č́slo položky } & Počet položek \\
\hline Všeobecně o ADHD & $\begin{array}{l}1,4,6,13,17,19,22,24,27, \\
28,29,30,31,32,33\end{array}$ & 15 \\
\hline Symptomy \& diagnostika & $3,5,7,9,11,14,16,21,26$ & 9 \\
\hline Intervence \& terapie & $\begin{array}{l}2,8,10,12,15,18,20,23, \\
25,34,35,36\end{array}$ & 12 \\
\hline
\end{tabular}

Relativni KADDS skór je vhodný pro vzájemné porovnání skórů jednotlivých subškál a celé škály, nebot̉ obsahují různé počty položek. Někteří autoři (Guerra 2012, Alkahtani 2013, Muanprasart 2014) používají při uvádění výsledků svých výzkumů pouze relativní $K A D D S$ skór a bez jeho znalosti by tedy nebylo možno provést ani komparace s těmito pracemi.

Škála KADDS byla vyvinuta v USA v anglickém jazyce. Její vývoj, ověřování a psychometrické vlastnosti jsou podrobněji popsány ve výše uvedeném přehledu (Soroa 2013). Při formulaci položek autoři vycházeli z odborné literatury a v dokumentaci ke KADDS zdroje jednotlivých tvrzení citovali. Na sestavení jednotlivých subškál následně participovalo 40 doktorandů oboru klinické a školní psychologie, kteří přiřazovali jednotlivé položky k odpovídajícím subškálám. Konkrétní položka byla do subškály zařazena jen tehdy, jestliže mezi doktorandy došlo alespoň k 75\% shodě. Tak bylo zkonstruováno prvních 27 položek ověřených v roce 1994 testem - retestem na vzorku 73 učitelů 
amerických mateřských a základních škol. Na základě výsledků tohoto ověřování byly zpřesněny formulace jednotlivých položek a nástroj byl rozšířen o 9 dalších položek. Po opětovném ověřování a opravách se autorům podařilo zlepšit reliabilitu testu na hodnotu charakterizovanou pomocí koeficientu Cronbachovo alfa na hodnotu $a_{C}>0,8$.

Praktické použití škály KADDS je relativně jednoduché, nevyžaduje předchozí odbornou instruktáž respondenta a časová náročnost pro respondenta se pohybuje v rozmezí 15-20 min. Velkou výhodou je její autoevaluační forma, respondent podle svých znalostí a vědomostí sám hodnotí pravdivost výroků uvedených v jednotlivých položkách škály a své hodnocení si zapisuje do formuláře. Absolutní i relativní $K A D D S$ skór lze rychle a jednoduše stanovit podle jeho definičního vztahu jak pro celou škálu, tak i pro každou ze tří subškál Všeobecně o ADHD, Symptomy \& diagnostika a Intervence \& terapie. V případě elektronické verze škály tak lze celý proces sběru dat a výpočtu KADDS skórů automatizovat včetně výpočtu popisné statistiky, $\mathrm{v}$ případě tištěné verze škály je však nutné manuálně provést kódování správných odpovědí a odpovídající hodnoty zapsat do datové matice ve vhodném tabulkovém editoru. Výpočty statistických veličin pak lze provést přímo v tabulkovém editoru, nebo data exportovat do vhodného statistického programu k dalšímu zpracování.

\subsubsection{Reliabilita, validita a stabilita KADDS}

Hodnocení reliability škály KADDS provedli autoři běžnými statistickými metodami. Východiskem pro hodnocení reliability bylo stanovení vnitřní konzistence pomocí koeficientu Cronbachovo alfa $a_{c}$, který se autorům podařilo postupně zvýšit $\mathrm{z}$ původní hodnoty $a_{C}=0,31$ na výsledných $a_{C}=0,81$. Pro španělskou lokalizaci KADDS se dokonce uvádí hodnota $a_{C}=0,89$ (Jarque Fernández 2007). Je tedy možné, že jednotlivé položky škály KADDS mají v různých jazykových verzích jemné významové nuance a vnitřní konzistence vzniklých celků - subškál 
se pak může mírně lišit. Současně je třeba také dodat, že metoda odhadu reliability pomocí koeficientu Cronbachovo alfa $\alpha_{C}$ je sice často používaná, současně se však v literatuře uvádějí také významná omezení a dezinterpretace související s jejím použitím, nap̌̌. to, že je pouze dolní mezí reliability a silně ji podhodnocuje v případě, kdy položky nepopisují stejnou oblast vědomostí. Necharakterizuje reliabilitu správně také v případech, pokud jsou v měření vedle náhodných chyb obsaženy také další chyby. Konečně, reliabilita je silně závislá na homogenitě testovaného souboru - mají-li respondenti podobné znalosti, je odhad reliability nižší než v případě respondentů s různými znalostmi (Sijtsma 2009). Nelze tedy snadno a jednoznačně identifikovat příčiny rozdílů hodnot koeficientu Cronbachovo alfa $a_{c}$ a jeho hodnoty by bylo žádoucí doplnit dalšími odhady spolehlivosti Zinbarg 2005).

Dále autoři hledali vzájemnou korelaci mezi skóry jednotlivých subškál KADDS a celou škálou KADDS. Zjištěný korelační koeficient $r$ se pohyboval v rozmezí 0,85<r<0,91 (Sciuto 2000a), resp. $\quad 0,85<r<0,90$ (Jarque Fernández 2007) a svědčí o silné závislosti. Hodnoty $r$ vzájemné korelace jednotlivých subškál KADDS byly horší a pohybovaly se v rozmezí $0,63<r<0,69$ (Sciuto 2000a), resp. 0,62<r<0,69 (Jarque Fernández 2007).

Stabilitu KADDS ověřovali autoři škály na vzorku 185 vysokoškolských studentů, kterým KADDS zadali opakovaně s prodlevou dvou týdnů. Respondenti v jejich průběhu neměli možnost získat objektivní informace o problematice ADHD. Hodnota $r$ vzájemné korelace testu a retestu činila $r=0,76$ pro celou škálu KADDS, pro jednotlivé subškály se pak pohybovala v rozmezí 0,59<r<0,70 (Sciuto 2000a). 


\subsection{Dotazníkové šetření}

\subsubsection{Příprava, distribuce a zpracování dotazníku se škálou KADDS}

Výzkumné šetření bylo provedeno formou dotazníkového šetření. Byl navržen dotazník, který obsahoval 3 části:

- úvodní část s údaji o respondentovi, která sloužila jako podklad pro popisnou statistiku a zčásti také pro analýzu závislostí,

- střední část s položkami škály KADDS, která sloužila jako podklad pro zjištění znalostí respondentů o ADHD,

- hodnotící část, ve které respondenti posuzovali doporučení pro práci s dětmi s ADHD a uváděli četnost, se kterou je používají.

Byla provedena pilotáž dotazníku, při které byla ověřena srozumitelnost a zpracovatelnost dotazníku. Dotazník bude po dobu udržitelnosti projektu dostupný v elektronické verzi na webu projektu na adrese http://inkluze.ujep.cz/cz/co-nabizime/dotaznik-ucitel-zaci-adhd.html.

Tištěná verze dotazníku byla až na distribuční médium shodná s elektronickou verzí.

Dotazníkové formuláře byly distribuovány do škol cílové skupiny v elektronické a/nebo tištěné verzi v prvním pololetí školního roku 2014/2015. Výběr respondentů byl proveden vícestupňovým náhodným výběrem ze základního souboru pedagogických pracovníků mateřských, základních a praktických škol. Respondenti dotazníky vyplnili a formuláře vrátili zpět ke zpracování. Po formální kontrole úplnosti vyplněných dotazníků a vyřazení nevalidních dotazníků zůstalo pro další zpracování 240 validních dotazníků. Data byla zpracována běžnými postupy, hodnoty odpovědí vyznačené ve formulářích byly překódovány a převedeny do digitální datové matice v tabulkovém editoru Excel a dále exportovány do programu Statistica. 
Položky dotazníku a tím i položky matice se typově odlišovaly, nebot odpovídaly hodnotícím proměnným různých typů:

- ordinální hodnoticí proměnná (výběr z více, jak dvou možností),

- dichotomická hodnoticí proměnná (výběr ze dvou možností),

- hodnoticí proměnná metrického typu (hodnoty nabývají různých metrických hodnot).

Protože dotazníkovému šetření předcházela pilotáž, mohlo již vlastní šetření probíhat s finálním zněním jednotlivých položek, které již v průběhu testu nebyly nikterak korigovány.

Při porovnání vybraných položek (např. genderová a věková struktura, kvalifikační struktura) daty zjištěnými Českým statistickým úřadem byla zjištěna dobrá shoda potvrzující náhodnost výběru vzorku respondentů ve provedeném výzkumu UJEP 2015.

Bylo překvapující, že byt měli učitelé $\mathrm{k}$ dispozici elektronickou verzi dotazníku přístupnou pomocí webového rozhraní, přesto výrazně preferovali vyplňování tištěné verze, a to v poměru cca 20:1. Je nutno konstatovat, že přes deklarované rostoucí využívání informačních a komunikačních technologií v českých školách (např. Rambousek 2013, Pešat 2015), není pro učitele běžné a normální prakticky používat počítač ke standardním administrativním činnostem jako je vyplňování dotazníku při výzkumnému šetření, u kterého nebyla nadřízenými složkami stanovena povinnost elektronického vyplňování.

\subsubsection{Použité statistické metody zpracování}

$\mathrm{K}$ analýze získaných dat bylo přistupováno zcela nepředpojatě v tom smyslu, že byly podrobně zkoumány všechny možné vztahy mezi sledovanými veličinami. K tomuto pojetí přispěl i fakt, že vztahy mezi veličinami nemusí být obecně tranzitivní (tj. je-li určitý vztah mezi veličinami $\mathrm{A}$ a $\mathrm{B}$ a také mezi $\mathrm{B}$ a $\mathrm{C}$, nemusí to nutně znamenat, že stejný vztah nalezneme mezi veličinami $\mathrm{A}$ a $\mathrm{C}$ ). 
Při výzkumu byly použity metody pro hromadné získávání dat a jejich následné zpracování. Během testování byla získána data různého charakteru, byly rozlišeny závislé a nezávislé výběry, nominální, ordinální a metrické náhodné veličiny. U metrických veličin byla posouzena jejich normalita a podle výsledku byly zvoleny vhodné parametrické či neparametrické statistické metody.

V průběhu šetření byly použity následující statistické metody a techniky:

- Průzkumová analýza jednorozměrných dat - tato analýza byla provedena zejména $\mathrm{z}$ důvodu identifikace statistických zvláštností dat a rozdělení četností diskrétních náhodných veličin.

- Statistická analýza jednorozměrných dat, kdy tento výběr byl charakterizován zejména informací o střední hodnotě a rozptýlením kolem této střední hodnoty.

- Testování normality (Shapirův-Wilkův test normality, K-S Liliefors test normality).

- Neparametrické testování hypotéz (Mann-Whitney test, Wilcoxon párový test, Kruskal-Wallis test, mediánový test).

- Testy nezávislosti (kontingenční tabulky).

- Shluková analýza.

Veškerá šetření (ověřování hypotéz) probíhala na pětiprocentní hladině významnosti $(\alpha=5 \%)$. Tam, kde to bylo možné, bylo šetření provedeno na jednoprocentní hladině významnosti $(\alpha=1 \%)$.

Ke každé ze závislostí byla vytvořená příslušná věcná/alternativní a nulová hypotéza, která byla následně ověřena vhodnou statistickou metodou. Zpravidla byl použit Pearsonův chí-kvadrát $\left(x^{2}\right)$ test pro kontingenční (někde i čtyřpolní) tabulky a Mann-Whitney test. Jelikož Pearsonův momentový korelační koeficient může být nositelem důležité informace, byl také na mnoha místech dopočítán. 
Matematicko-statistické zpracování bylo provedeno standardními statistickými metodami, zčásti přímo $\mathrm{v}$ tabulkovém editoru Microsoft Excel (ve verzi, která je součástí kancelářského balíku Microsoft Office Standard 2010), zčásti v specializovaném statistickém programu Statistica verze 12 (firmy StatSoft).

\subsubsection{Označení statistických veličin}

Statistické veličiny uváděné ve výzkumné části práce jsou používány ve shodě s českou odbornou statistickou literaturou (Hendl 2012). V textu, grafech a tabulkách byla použita následující označení a zkratky:

- $a_{C} \quad$ Cronbachovo alfa,

- abs. absolutní počet,

- $x^{2} \quad$ chí-kvadrát,

- max. maximum,

- Ø aritmetický průměr, průměrná hodnota (mean value),

- med. median,

- mod. modus,

- min. minimum,

- $N$ počet jedinců (např. respondentů),

- $p$ hladina významnosti testu, tzv. $p$-level, resp p-value,

- $r \quad$ korelační koeficient,

- rel. relativní počet,

- SD směrodatná odchylka (standard deviation).

Zjištěné hodnoty jsou v textu uvedeny ve formě tabulek a grafů. Neníli v grafech uvedeno jinak, číselné hodnoty znamenají absolutní počty respondentů v dané kategorii (statistické třídě).

\subsection{Výsledky šetření KADDS}

Výsledky šetření UJEP 2014 o vědomostech pedagogických pracovníků o ADHD byly rozčleněny do čtyř částí. V první části je uvedena a 
komentována popisná statistika výběrového souboru, ve druhé části jsou uvedeny a analyzovány KADDS skóry celé škály a jednotlivých subškál včetně jejich vzájemného porovnání, ve třetí části jsou uvedeny KADDS skóry různých kategorií respondentů s verifikací statistické významnosti jejich vzájemných rozdílů a v poslední, čtvrté části, jsou uvedeny úspěšnosti jednotlivých položek škály KADDS. Konkrétně zde jsou uvedeny, popsány a případně analyzovány následující kategorie a závislosti:

1. Popisná statistika respondentů. V tomto oddíle jsou uvedena následující popisná data charakterizující výběrový soubor:

- Genderové rozdělení respondentů.

- Věkové rozdělení respondentů.

- Rozdělení respondentů podle délky pedagogické praxe.

- Rozdělení respondentů podle dosaženého vzdělání.

- Rozdělení respondentů podle pracovního zařazení.

- Rozdělení respondentů podle typu školy, na které působí.

- Rozdělení respondentů podle zkušeností ze školní praxe.

- Rozdělení respondentů podle zkušeností ze soukromého života.

- Rozdělení respondentů podle sebehodnocení znalostí o ADHD.

- Rozdělení respondentů podle didaktické formy, kterou by volili pro případné další vzdělávání o ADHD.

2. Absolutní a relativní KADDS skóry pro celou škálu KADDS a její jednotlivé subškály. Zde jsou uvedeny a analyzovány KADDS skóry celé škály a jednotlivých subškál včetně jejich vzájemného porovnání metodou zjištění jejich vzájemných korelací:

- Průměrný KADDS skór celé škály.

- Rozdělení četností absolutního KADDS skóru.

- Průměrný KADDS skór - subškála Všeobecně o ADHD.

- Průměrný KADDS skór - subškála Symptomy \& diagnostika.

- Průměrný KADDS skór - subškála Intervence \& terapie. 
- Vzájemné porovnání KADDS skóru jednotlivých subškál a celé škály, vzájemné korelace.

- Reliabilita KADDS skórů celé škály a jednotlivých subškál.

3. Korelace mezi vybranými skupinami respondentů a jejich výsledky KADDS skóru. V tomto oddíle jsou uvedeny a analyzovány KADDS skóry vybraných skupin respondentů:

- Vzdělání respondenta × celkový relativní KADDS skór.

- Pracovní zařazení respondenta $\times$ celkový relativní KADDS skór.

- Typ školy, na které respondent pracuje $\times$ celkový relativní KADDS skór.

- Zkušenost respondenta s dětmi s ADHD × celkový relativní KADDS skór.

- Zkušenost respondenta s jedincem s ADHD mezi př́íbuznými nebo přáteli $\times$ celkový relativní KADDS skór.

- Sebehodnocení vlastních znalostí respondenta o $\mathrm{ADHD} \times$ celkový relativní KADDS skór.

- Potřeba sebevzdělávání × celkový relativní KADDS skór.

KADDS skóry jednotlivých kategorií respondentů ve vybraných skupinách byly vzájemně porovnány a byly provedeny testy statistické významnosti jejich vzájemných rozdílů.

4. Úspěšnosti jednotlivých položek škály KADDS. Zde jsou uvedeny a analyzovány úspěšnosti jednotlivých položek škály KADDS a dále jsou zde uvedeny příklady nejvíce a nejméně úspěšných položek:

- Relativní úspěšnosti položek celé škály KADDS.

- Rozdělení položek škály KADDS podle úspěšnosti.

- Rozdělení položek subškály Všeobecně o $A D H D$ podle úspěšnosti.

- Rozdělení položek subškály Symptomy \& diagnostika podle úspěšnosti.

- Rozdělení položek subškály Intervence \& terapie podle úspěšnosti. 


\subsubsection{Popisná statistika}

\subsubsection{Genderové složení respondentů}

Genderové složení respondentů vykazuje velmi výraznou převahu počtu žen nad počtem mužů v poměru cca $15: 1$, viz tabulka 6 .

Tabulka 6: Genderové rozdělení respondentů

\begin{tabular}{|l|r|r|}
\hline & \multicolumn{2}{|c|}{ Počet respondentů } \\
\hline \multicolumn{1}{|c|}{ Gender } & abs. [n] & \multicolumn{1}{c|}{ rel. [\%] } \\
\hline Muži & 15 & 6,3 \\
\hline Ženy & 225 & 93,7 \\
\hline Celkem & 240 & 100 \\
\hline
\end{tabular}

Výrazně se projevil pro naše školství již typický a neustále připomínaný jev feminizace školství - ženy učitelky dominují ve své profesi početně několikanásobně nad muži - učiteli. Tento jev je často zdůvodňován nízkým finančním ohodnocením učitelské profese a nedoceněným postavením pedagoga $\mathrm{v}$ naší společnosti. Domníváme se však ve shodě s Havlíkem a Kotou (2007, s. 13), že je obtížné charakterizovat postavení učitele ve společenské struktuře. Způsobuje to snaha hodnotit dohromady učitele různých typů škol, různých aprobací i učitele $\mathrm{z}$ různých lokalit, přičemž lze vnímat někdy i markantní rozdíly v postavení učitele ve velkém městě, v malém městě nebo na vesnici. Společenská pozice učitele je sice odvozena od jeho postavení v rámci školské soustavy a uvnitř jednotlivých škol (včetně regionu v němž škola působí), ale profese učitele je současně situována do celkové sociální struktury společnosti, která ji limituje. Při srovnání se statistickými daty českého školství se navíc ukázalo, že mezi respondenty šetření UJEP 2015 byli muži zastoupeni méně, než by odpovídalo váženému odhadu dle publikovaných údajů ČSÚ 2014 (15 oproti očekávaným 23). 


\subsubsection{Věková struktura respondentů}

Největší počet respondentů byl ve věku 52 let, průměrný věk respondentů činil 43,85 roku se směrodatnou odchylkou SD=11,1 roku. Nejmladší respondentce bylo 20 let, nejstarší pak 68 let. Při srovnání se statistickými daty českého školství byla potvrzena věková reprezentativnost souboru respondentů UJEP 2015, která v rámci statistických chyb odpovídá údajům ČSÚ 2013 s tendencí vyššího zastoupení věkových skupin 25-34 let a 55-65 let. Věkové charakteristiky souboru respondentů jsou uvedeny v grafu 1 a souhrnně pak v tabulce 7 .

Tabulka 7: Věkové rozdělení respondentů

\begin{tabular}{|r|c|c|c|c|c|c|r|}
\hline & \multicolumn{7}{|c|}{ Věk respondentů } \\
\hline & $\varnothing[$ rok] & SD [rok] & min. [rok] & max. [rok] & mod. [rok] & med. [rok] & abs. [n] \\
\hline Respondenti & 43,85 & 11,1 & 20 & 68 & 52 & 45 & 240 \\
\hline
\end{tabular}

Věkové rozdělení respondentů na grafu 1 je asymetrické s jedním maximem a nevykazuje vizuálně žádné výrazné anomálie.

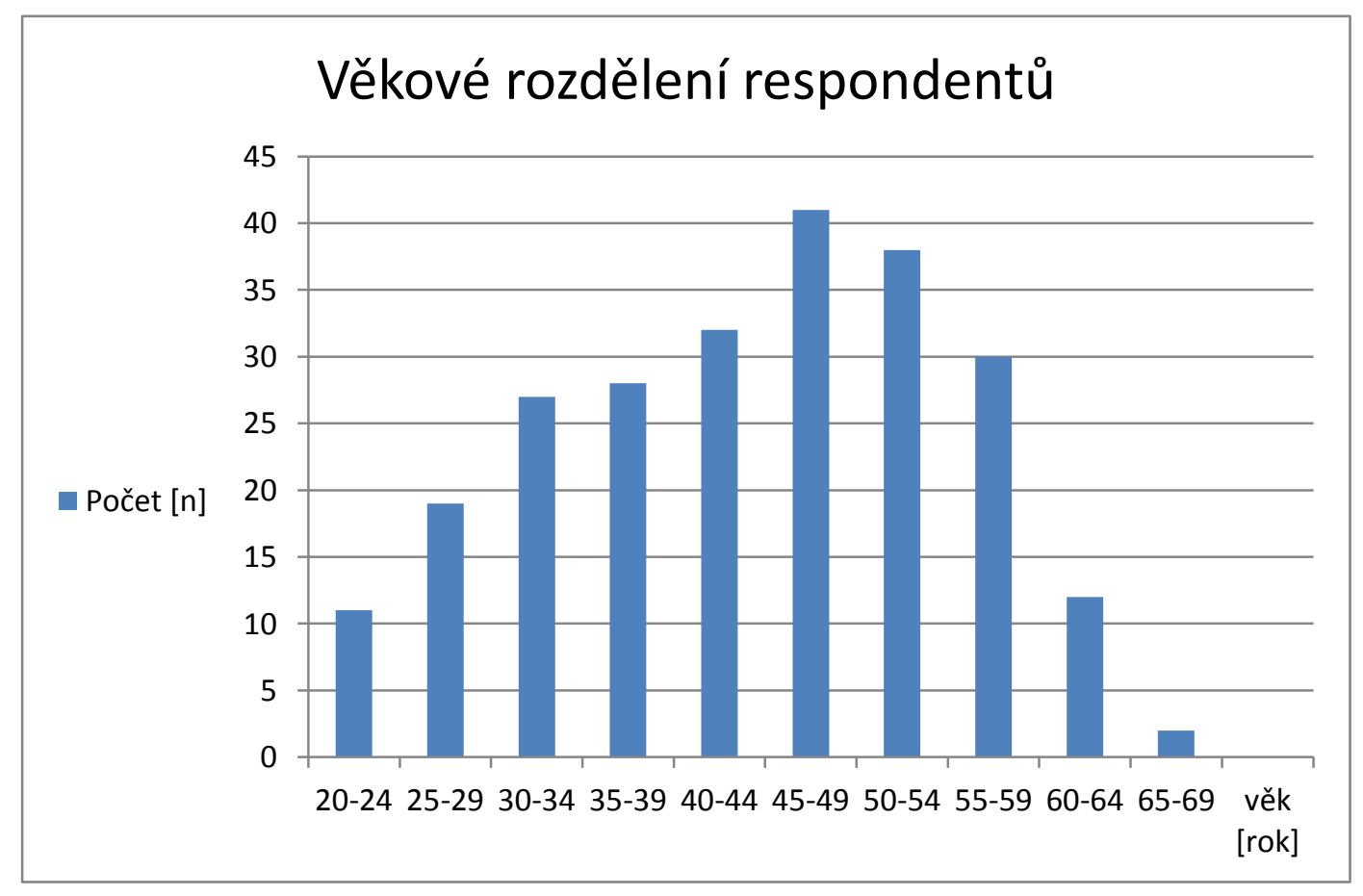

Graf 1: Věkové rozdělení respondentů 
Genderová a věková struktura byla $\mathrm{v}$ překvapivě dobré shodě se strukturou Sciuttova výzkumného souboru, ve kterém průměrný věk respondentů činil 41 let se směrodatnou odchylkou $\mathrm{SD}=11,43$ roku a který obsahoval 6,3 \% mužů (Sciutto 2000a).

\subsubsection{Délka praxe respondenta}

Respondenti mají různou pedagogickou zkušenost, délka jejich praxe se pohybuje od absolventů s krátkou jednoletou praxí až po zkušeného pedagoga s praxí 46 let. Průměrná délka pedagogické praxe činila 19,45 roku se standardní odchylkou $\mathrm{SD}=12$ let. Většinu respondentů $(\mathrm{N}=206)$ lze zařadit do kategorie zkušených pedagogů s praxí delší než 5 let, od nichž se očekává, že nepotřebují vedení v edukaci a dokáží si již s každou situací, kterou edukace přináší, poradit (Vašutová 2004; Deiner, 2010). Nejčetnější skupinou respondentů však byli absolventi s praxí 1 rok (mod. =1). Přehledné statistické údaje o délce praxe respondentů jsou uvedeny v tabulce 8 .

Tabulka 8: Délka pedagogické praxe respondentů

\begin{tabular}{|r|r|r|r|r|r|r|r|}
\hline & \multicolumn{7}{|c|}{ Počet let pedagogické praxe respondentů } \\
\hline & $\phi[$ [rok] & SD [rok] & min. [rok] & max. [rok] & mod. [rok] & med. [rok] & abs. [n] \\
\hline Respondenti & 19,45 & 12,0 & 1 & 46 & 1 & 20 & 240 \\
\hline
\end{tabular}

Závislost na délce pedagogické praxe vykazuje dvě výrazná maxima odpovídající dvěma skupinám pracovníků $s$ praxí do deseti let a pracovníků s praxí mezi 20 až 35 roky, viz graf 2 . Mezi skupinami s 5-9 lety praxe a s praxí v rozmezí 10-14 let je patrný výrazný pokles, který může souviset $\mathrm{s}$ nenaplněním profesních očekávání pedagogů nebo syndromem vyhoření.

Délka pedagogické praxe respondentů byla statisticky významně větší než v případě Sciuttova výzkumu, kdy činila 12,6 roku se směrodatnou odchylkou SD = 8,06 roku (Sciutto 2000a). 


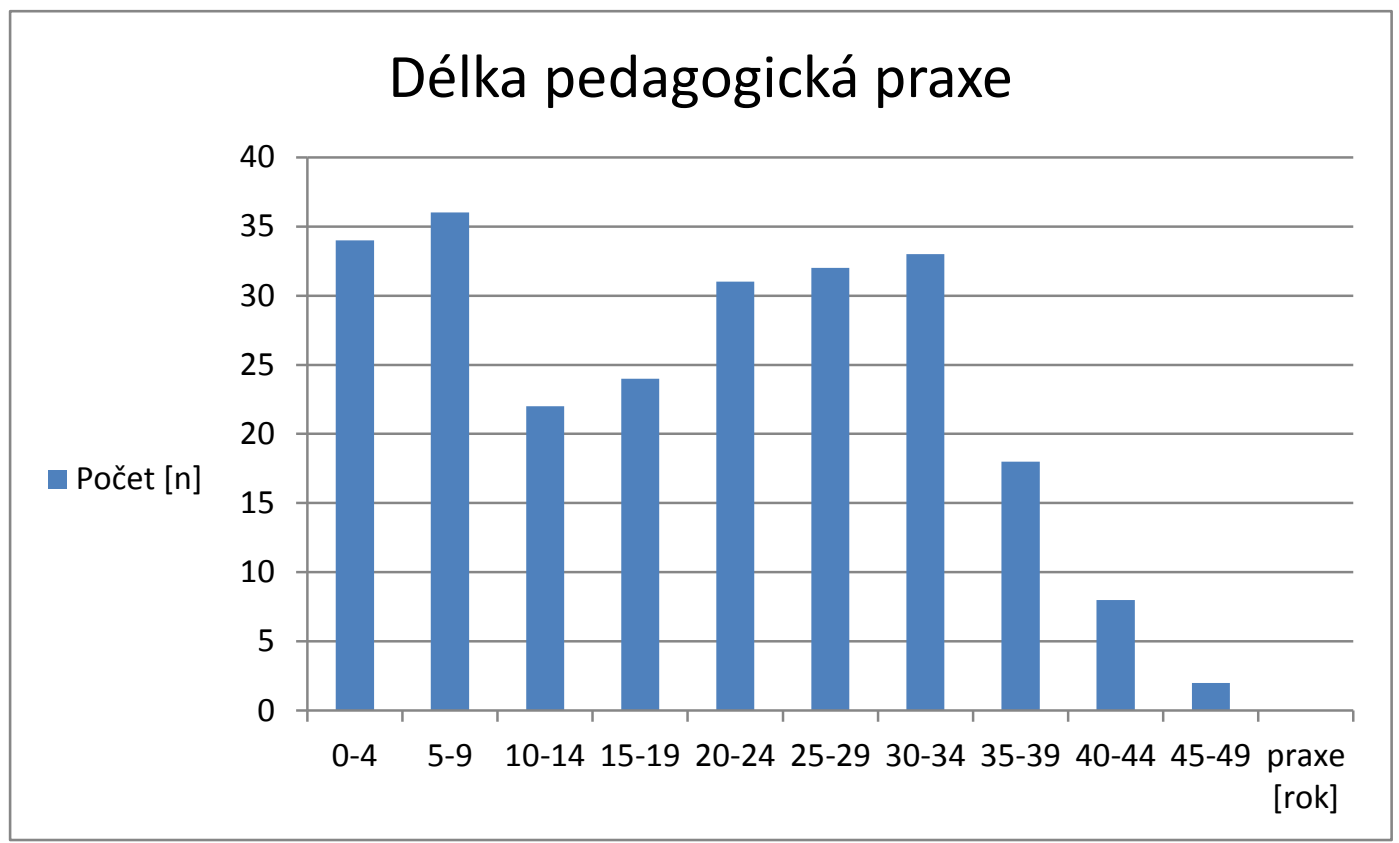

Graf 2: Délka pedagogické praxe

\subsubsection{Nejvyšší dosažené vzdělání respondenta}

Součástí popisné části šetření byla také položka nejvyšší dosažené vzdělání doplněná o uvedení získaného vysokoškolského titulu. Přibližně jedna třetina respondentů uvedla středoškolské vzdělání postačující pro výkon profese učitele, resp. učitelky mateřské školy a přibližně dvě třetiny respondentů dosáhly pedagogického nebo humanitního vysokoškolského vzdělání, viz graf 3 . Počet pedagogů, kteří získali inženýrský titul na technických, resp. ekonomických nebo zemědělských vysokých školách, je prakticky zanedbatelný $(\mathrm{N}=8$, tj. cca $3 \%)$ a nebyl vyčleněn do samostatné kategorie. Přibližně $10 \%$ respondentů absolvovalo po maturitě další formální vzdělávání na vyšší odborné škole, vysokoškolské bakalářské studium nebo doplňkové pedagogické studium, což je pro výkon některých pedagogických profesí postačující (učitel/učitelka mateřské školy, vychovatel/vychovatelka). 


\section{Nejvyšší dosažené vzdělání ( $N$ = 240)}

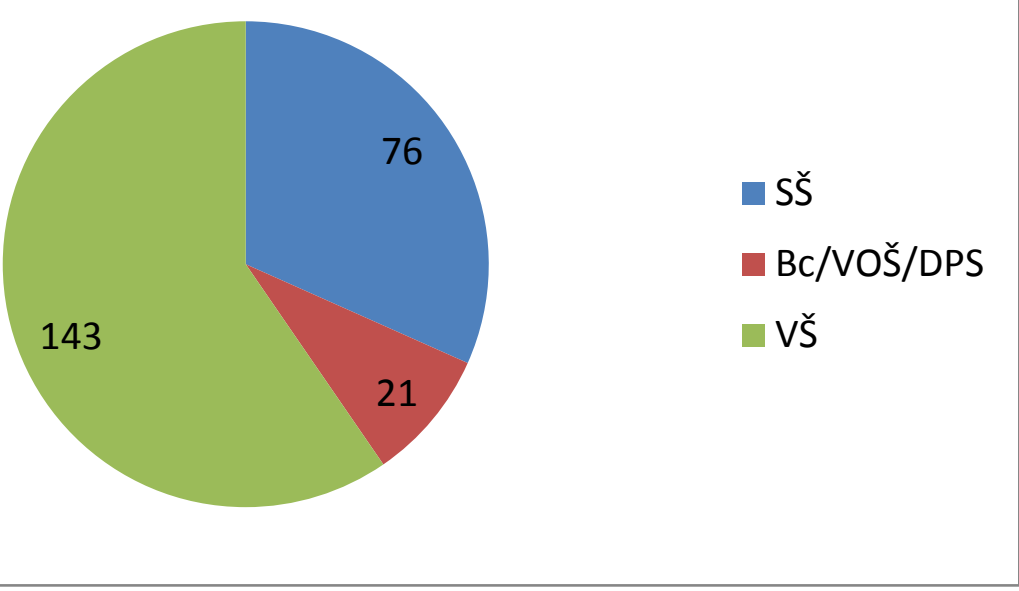

Graf 3: Nejvyšší dosažené vzdělání

\subsubsection{Pracovní zařazení respondenta ve škole}

Počty pedagogů v jednotlivých kategoriích pracovního zařazení odpovídají rozdělení četností škol, ve kterých působí. Třetinu respondentů tvořily učitelky mateřských škol, přičemž v této skupině nebyl zastoupen ani jeden muž. Také kategorii učitelek prvního stupně tvořily až na jedinou výjimku samé ženy. Polovinu respondentů tvořili učitelé a učitelky 1. a 2. stupně základní školy. Do kategorie speciální pedagog / speciální pedagožka byli také zahrnuti pracovníci zařazení na pozici výchovný poradce (1 respondent) a školní psycholog (1 respondent). Do kategorie vedení školy, tj. ředitel(ka) bylo také zahrnuto 6 respondentů na pozici zástupce, resp. zástupkyně ředitele / ředitelky. Vedoucí pedagogičtí pracovníci a neučitelští pedagogičtí pracovníci tvořili cca $15 \%$ respondentů. Souhrnně jsou údaje o pracovním zařazení respondentů uvedeny v tabulce 9 . 
Tabulka 9: Pracovní zařazení respondenta ve škole

\begin{tabular}{|l|r|r|}
\hline & \multicolumn{2}{|c|}{ Počet respondentů } \\
\hline \multicolumn{1}{|c|}{ Zařazení } & abs. [n] & \multicolumn{1}{c|}{ rel. [\%] } \\
\hline Učitel(ka) MŠ & 80 & 33,3 \\
\hline Učitel(ka) ZŠ 1. stupeň & 58 & 24,2 \\
\hline Učitel(ka) ZŠ 2. stupeň & 65 & 27,1 \\
\hline Vychovatel(ka) & 12 & 5,0 \\
\hline Speciální pedagog(žka) & 8 & 3,3 \\
\hline Ředitel(ka) & 17 & 7,1 \\
\hline Celkem & 240 & 100,0 \\
\hline
\end{tabular}

Pro názornost jsou údaje z tabulky uvedeny ještě v grafu 4, ze kterého je jasně patrná převaha učitelů / učitelek nad vedoucími pracovníky a specializovanými neučitelskými pedagogy.

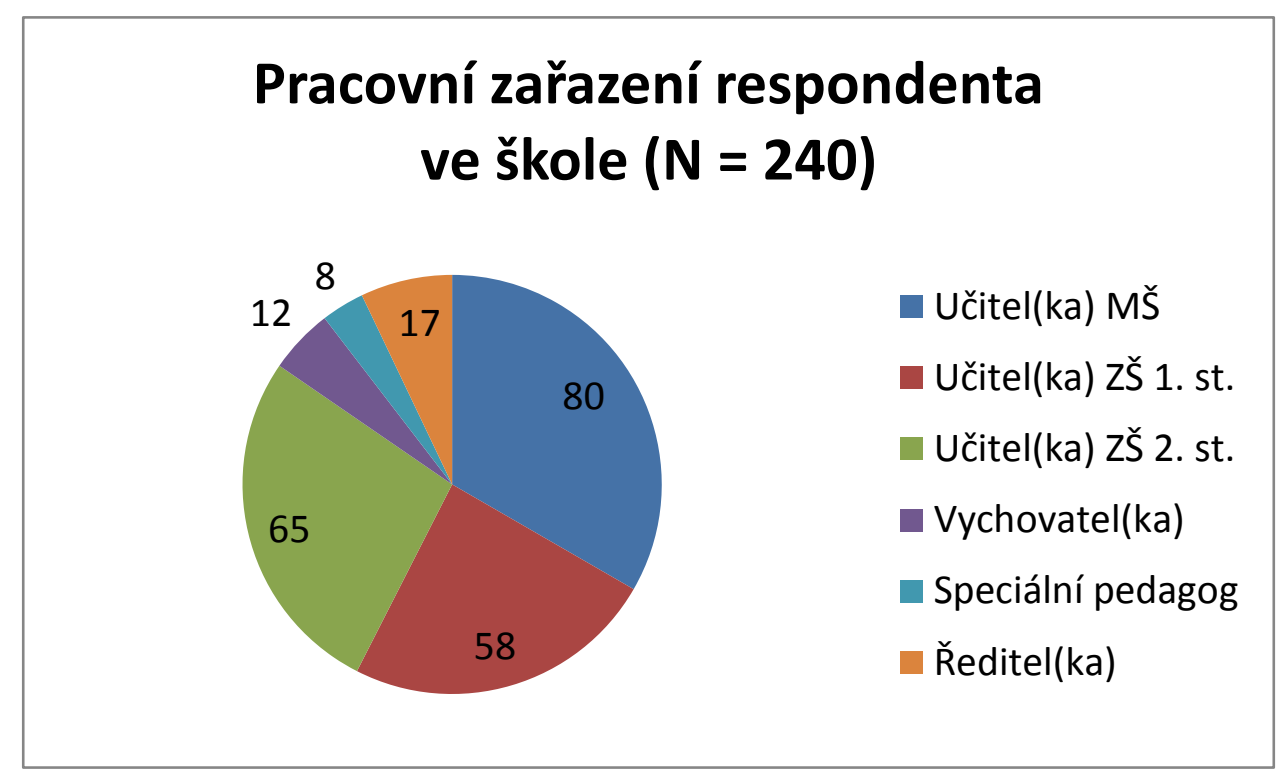

Graf 4: Pracovní zařazení respondenta ve škole

Při přípravě výzkumu byly zjištěny případy pedagogů, jejichž pracovní zařazení ve škole neodpovídá druhu školy, na kterém působí (např̀ v mateřské škole pracuje pedagožka s kvalifikací a pracovním zařazením učitelky pro 1. stupeň). Také proto byla do dotazníku zařazena ještě následující položka druh školy, na které respondent pưsobí. 


\subsubsection{Druh školy, na které respondent působí}

Součástí popisné části šetření bylo zjištění druhu školy, na které respondent působí. Školy byly rozděleny způsobem odpovídajícím formální struktuře škol na školy mateřské, školy základní odděleně pro 1. a pro 2. stupeň a základní školy praktické. Rozdělení četností respondentů podle druhu školy je pak uvedeno v grafu 5. Největší počet respondentů byl $\mathrm{z}$ mateřských škol, zastoupení respondentů působících na prvním a druhém stupni základní školy bylo přibližně vyrovnané. Druh školy, na které respondent působí, dobře koreluje $\mathrm{s}$ jeho pracovním zařazením a také s jeho nejvyšším dosaženým vzděláním a svědčí o dodržování zákona č. 563/2004 Sb., o pedagogických pracovnících a o změně některých zákonů. Respondenti, kteří vyučují na základních školách praktických, byli zastoupeni relativně velmi málo, jen cca $4 \%$.

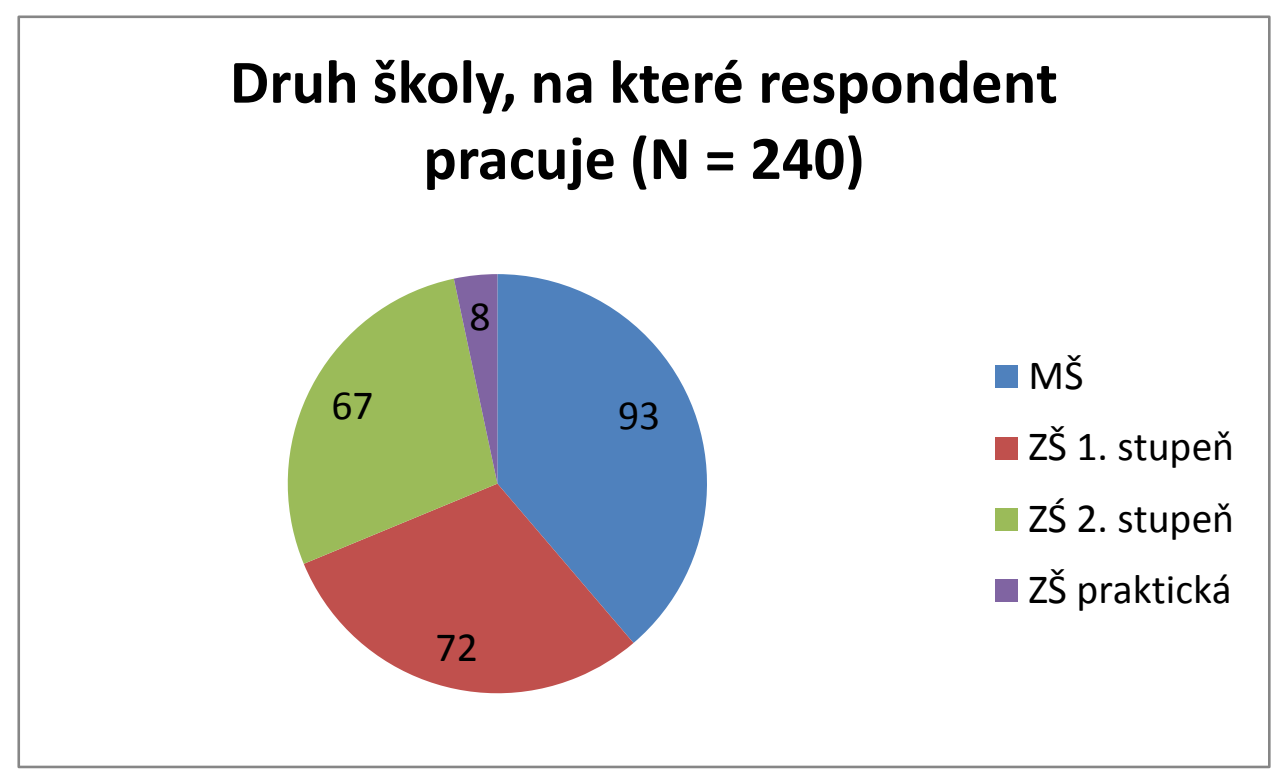

Graf 5: Druh školy, na které respondent pracuje

\subsubsection{Zkušenosti respondenta ze školní praxe}

Respondenti dále uváděli, zda mají nějaké vlastní praktické zkušenosti s dětmi s poruchou ADHD. Zjištěné výsledky jsou uvedeny v grafu 6. Ukázalo se, že výrazná většina respondentů nějaké zkušenosti se žáky s ADHD získané ve školní praxi má, nadpoloviční většina respondentů (56\%) dokonce uvedla, že má zkušenosti s více než 5 žáky s ADHD. Přímá praktická pedagogická zkušenost $\mathrm{s}$ dětmi 
s poruchou ADHD je všeobecně považována za důležitý faktor, který by měl pozitivně ovlivňovat znalosti respondentů o poruše $\mathrm{ADHD}$ a samozřejmě také jejich potřebu dalšího odborného sebevzdělávání.

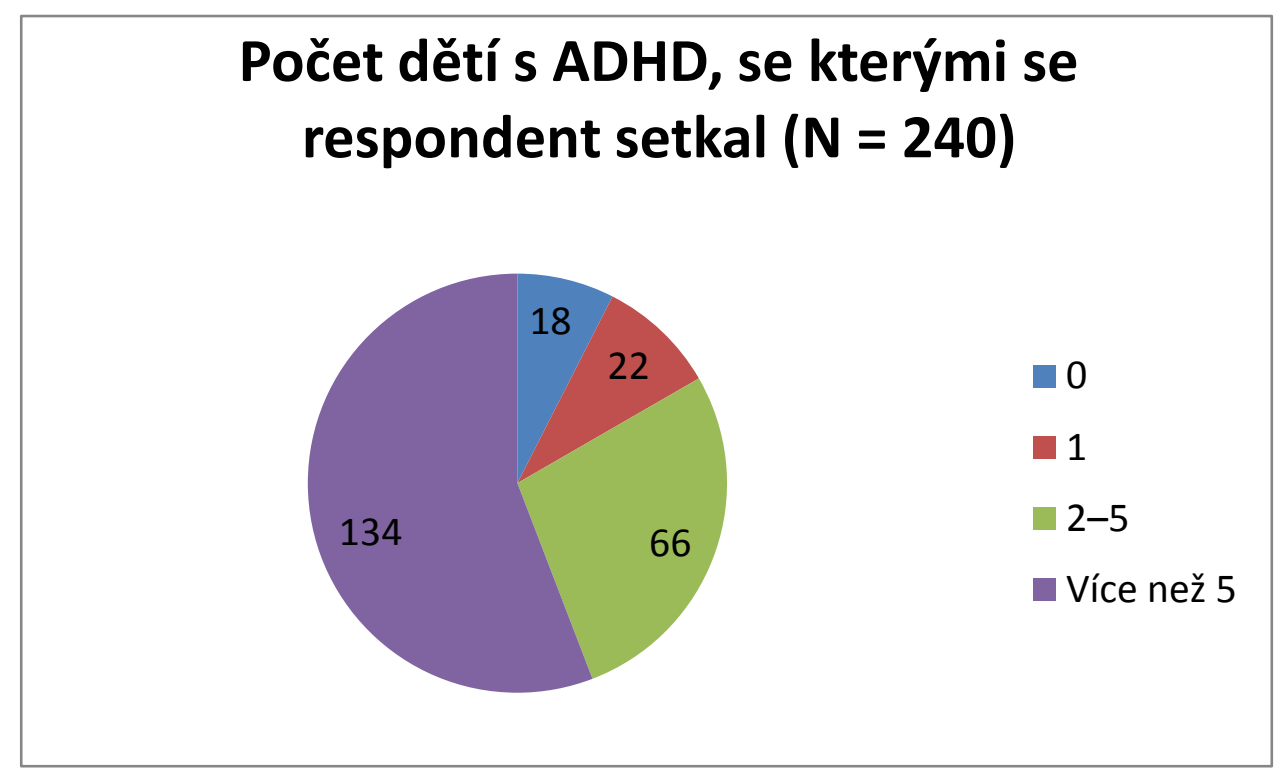

Graf 6: Počet dětí s ADHD, se kterým se respondent setkal

\subsubsection{Zkušenosti respondenta ze soukromého života}

Respondenti mohli získat znalosti o poruše ADHD také v soukromém životě, např. tím, že v rodině mají mezi příbuznými jedince s ADHD, případně takovou osobu mají v okruhu svých známých. Počet takových osob s ADHD respondenti uváděli v položce Jedinec s $A D H D$ mezi př́buznými/práteli, výsledky jsou uvedeny v grafu 7 . Ukázalo se, že v soukromém životě se stýká s jedinci s ADHD přibližně $20 \%$ respondentů, zanedbatelný počet 2 respondenti odpověd' neuvedli. Podobně jako $v$ předchozím případě lze očekávat, že zkušenost s jedinci s ADHD získaná v soukromém životě by mohla hrát významnou roli faktoru pozitivně ovlivňujícího znalosti respondenta o poruše ADHD a případně jeho potřebu dalšího odborného sebevzdělávání. 


\section{Jedinec s ADHD mezi př́buznými / práteli $(N=240)$}

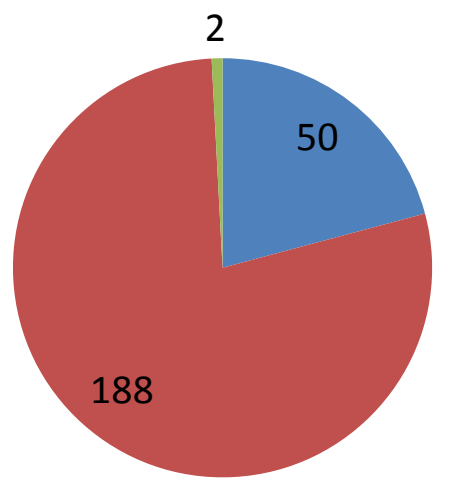

Ano

$\mathrm{Ne}$

Neuvedeno

Graf 7: Jedinec s ADHD mezi př́buznými / přáteli

\subsubsection{Sebehodnocení znalostí o ADHD}

Respondenti dále hodnotili své vlastní znalosti o ADHD, zejména z toho hlediska, zda jsou postačující pro jejich další pedagogickou práci. Výsledky tohoto sebehodnocení jsou uvedeny v grafu 8. Výrazná většina respondentů ( $55 \%$ ) zastávala názor, že jim jejich znalosti o ADHD postačují pro výkon pedagogické profese, cca $5 \%$ respondentů neuvedlo žádnou odpověd'.

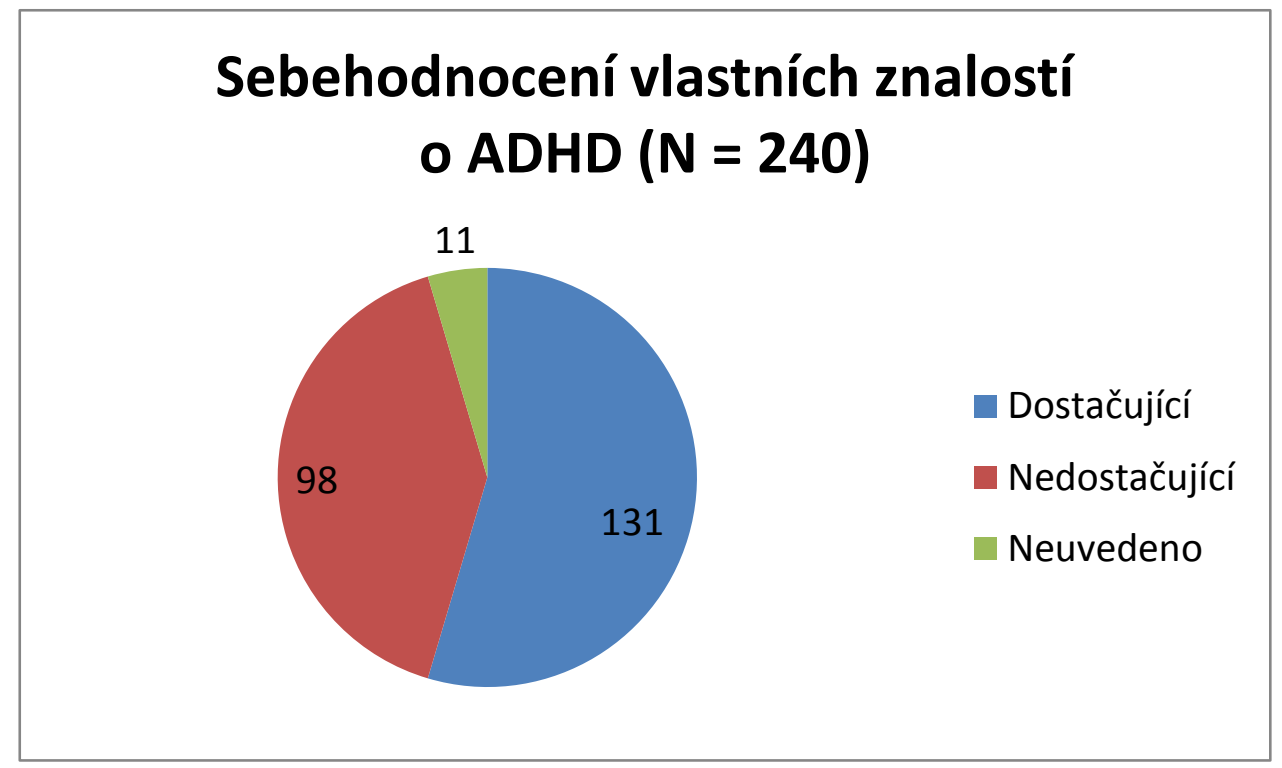

Graf 8: Sebehodnocení vlastních znalostí o ADHD 
Sebehodnocení a sebeuspokojení jsou významnými faktory, které ovlivňují postoj pedagogů $\mathrm{k}$ dalšímu odbornému sebevzdělávání. Pedagogičtí pracovníci se musí nutně dále vzdělávat a informovat o problematice $\mathrm{ADHD}$, aby lépe porozuměli těmto dětem a mohli zvolit vhodná výchovná opatření, účinné vyučovací metody a strategie zvládání jejich chování.

Aby dítě bylo ve škole úspěšné, potřebuje pozitivní perspektivní orientaci. Jestliže dítě vidí budoucnost jako otevřený horizont šancí a možností, je schopné aktivizovat své síly a navzdory případným neúspěchům se znovu vzchopit, aby dosáhlo svých cílů. Úkolem učitele je uplatňovat vůči dítěti osobnostní zřetel a dbát na utváření horizontu otevřené budoucnosti (Helus 2004).

\subsubsection{Didaktická forma získávání dalších znalostí o ADHD}

Respondenti také hodnotili didaktickou formu získávání znalostí o ADHD, jejíž přínos považují za nejvýznamnější a která by přinášela poznatky využitelné v jejich každodenní praxi. Výsledky jsou uvedeny v grafu 9. Formální vzdělávání ve škole a jiné organizované vzdělávání byly hodnoceny jako zhruba rovnocenné, poněkud menší přínos vidí respondenti $\mathrm{v}$ samostudiu. Překvapivé je, že více než třetina respondentů na tuto otázku neodpověděla.

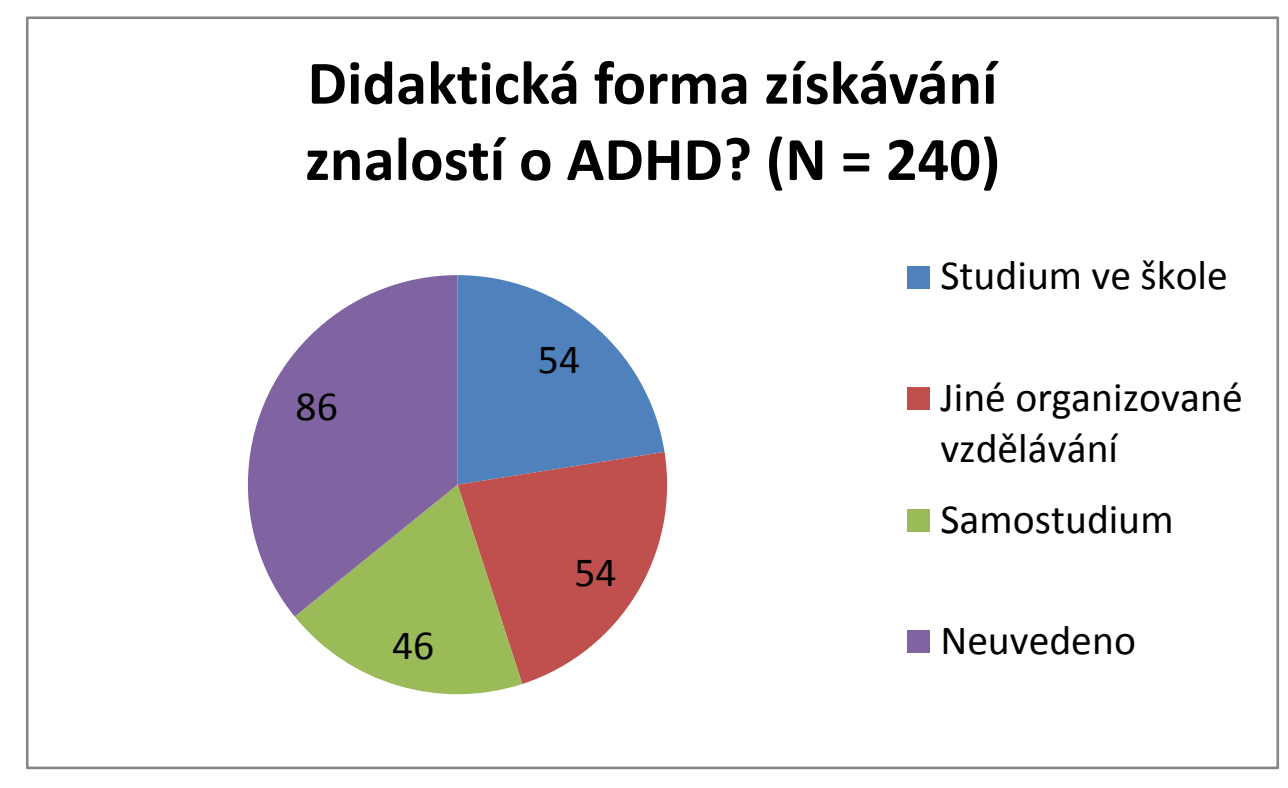

Graf 9: Didaktická forma získávání znalostí o ADHD 


\subsubsection{KADDS skóry a analýza znalostí pedagogů o ADHD}

Cílem použití výzkumného nástroje KADDS bylo stanovení znalostí učitelů v České republice o ADHD, zjištění jejich přehledu o podstatě a možnostech diagnostiky ADHD a znalosti intervenčních postupů vůči žákům s touto poruchou.

Pomocí nástroje KADDS byly zjištěny celkové KADDS skóry, které jsou uvedeny v tabulce 10, a to jak v absolutních bodech (škála 0-36), tak i přepočítané do relativní škály $0-100 \%$.

Tabulka 10: Celkový absolutní a relat. KADDS skór - celá škála (36 položek)

\begin{tabular}{|l|c|r|r|r|r|r|r|}
\hline & \multicolumn{6}{|c|}{ KADDS skór $\left(\mathrm{N}_{\mathrm{R}}=240\right.$ respondentů) } \\
\hline & $\varnothing[\mathrm{N}]$ & \multicolumn{1}{|c|}{ SD [N] } & min. [N] & max. [N] & mod. [N] & med. [N] & abs. [N $\left.\mathrm{N}_{\mathrm{R}}\right]$ \\
\hline Absolutní & 18,5 & 4,5 & 4 & 30 & 22 & 19 & 240 \\
\hline & $\varnothing[\%]$ & \multicolumn{1}{|c|}{ SD [\%] } & min. [\%] & max. [\%] & mod. [\%] & med. [\%] & abs. [N $\left.\mathrm{N}_{\mathrm{R}}\right]$ \\
\hline Relativní & 51,3 & 12,4 & 11 & 83 & 61 & 53 & 240 \\
\hline
\end{tabular}

Průměrný absolutní KADDS skór, kterého respondenti dosáhli, činí 18,5 bodu se standardní odchylkou $\mathrm{SD}=4,5$ bodu, tj. respondenti měli cca $50 \%$ úspěšnost v posuzování správnosti tvrzení o poruše ADHD. Za povšimnutí stojí skutečnost, že někteří respondenti dosáhli výrazně dobrých či špatných výsledků, což je patrné z minimálních a maximálních hodnot KADDS skóru. Nejnižší relativní úspěšnost činila $11 \%$, nejvyšší pak byla $83 \%$. Mezi respondenty nebyl žádný, kdo by správně neposoudil ani jedeno z tvrzení škály KADDS, nejnižší počet správných odpovědí byl 4 . Podobně nikdo z respondentů nedosáhl maximální úspěšnosti, nejvyšší počet správných odpovědí byl 30 z 36 možných.

Popisná statistika byla pro přehlednost doplněna o rozdělení četností absolutního KADDS skóru, které je uvedeno v grafu 10. Rozdělení je mírně asymetrické a Shapiro-Wilkův ani Lillieforsonův test nepotvrdily jeho normalitu, tj. rozdělení KADDS skóru nelze považovat za normální Gaussovo rozdělení. Proto byly pro jeho další statistické hodnocení zvoleny neparametrické testy. Vizuálně rozdělení nevykazuje žádné významné anomálie (např. více maxim, odlehlé body apod.), viz graf 10 . 


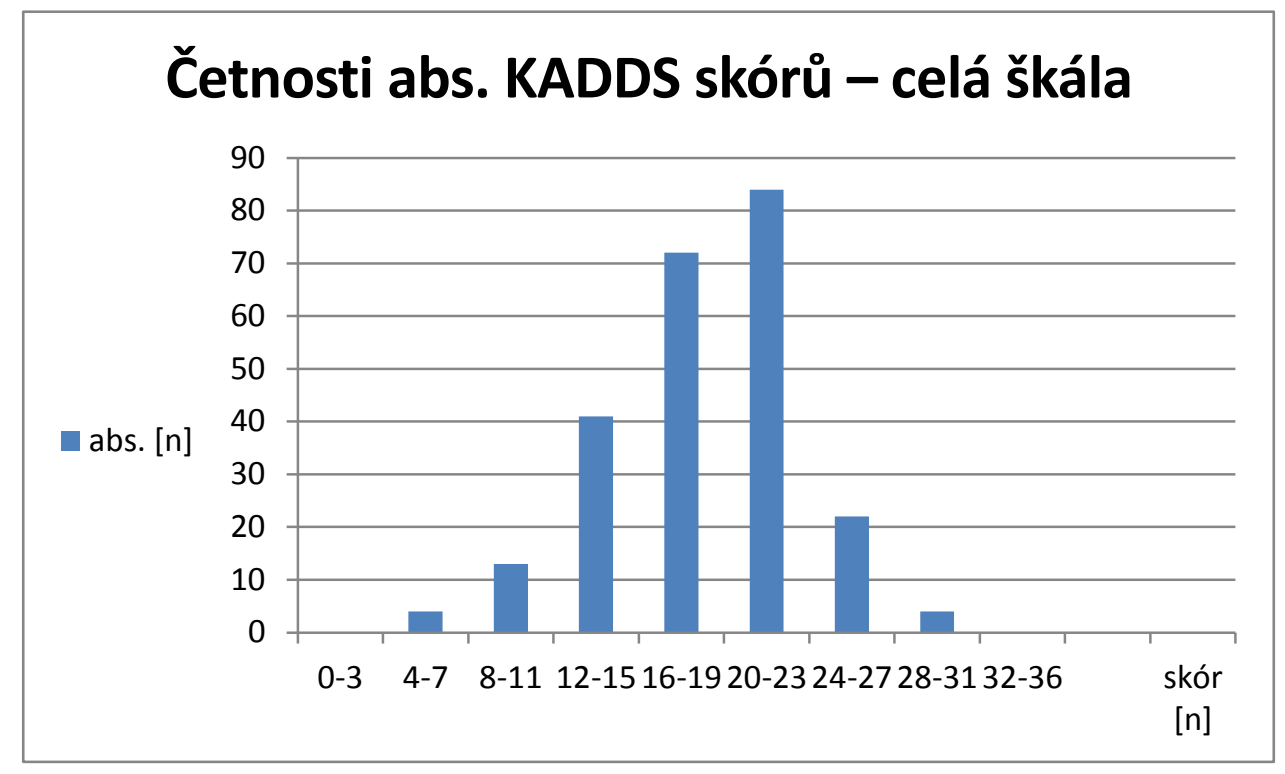

Graf 10: Četnosti absolutních KADDS skórů - celá škála

Analogicky byly zpracovány a tabelovány absolutní a relativní KADDS skóry jednotlivých subškál, viz tabulky 11 až 13. Vzájemné porovnání relativních KADDS skórů celé škály a jednotlivých subškál je pak uvedeno v tabulce 14. Při statistické komparaci se potvrdila statistická významnost rozdílů KADDS skóru a skóru jednotlivých subškál. Dále byly vypočteny vzájemné korelace KADDS skóru a skóru jednotlivých subškál, které vykazují vzájemnou závislost v rozsahu hodnot korelačního koeficientu $0,66<r<0,84$, viz grafy 11,12 a 13. Zjištěné korelace lze interpretovat tak, že mezi celkovým KADDS skórem a skóry jednotlivých subškál existuje vysoká lineární přímá závislost (subškály V̌̌eobecně o $A D H D$ a Intervence \& terapie), resp. střední lineární přímá závislost blížící se vysoké závislosti (subškála Symptomy \& diagnostika).

Tabulka 11: Abs. a rel. KADDS skór - subškála Všeobecně o ADHD (15 pol.)

\begin{tabular}{|c|c|c|c|c|c|c|c|}
\hline & \multicolumn{7}{|c|}{ KADDS skór subškály Všeobecně o $A D H D\left(\mathrm{~N}_{\mathrm{R}}=240\right.$ resp. $)$} \\
\hline & $\varnothing[N]$ & SD $[\mathrm{N}]$ & $\min .[\mathrm{N}]$ & $\max .[N]$ & mod. [N] & med. [N] & abs. $\left[\mathrm{N}_{\mathrm{R}}\right]$ \\
\hline Absolutní & 7,2 & 2,3 & 1 & 13 & 9 & 7 & 240 \\
\hline & $\varnothing[\%]$ & SD [\%] & $\min .[\%]$ & $\max .[\%]$ & mod. [\%] & med. [\%] & abs. $\left[\mathrm{N}_{\mathrm{R}}\right]$ \\
\hline Relativní & 48,1 & 15,6 & 7 & 87 & 60 & 47 & 240 \\
\hline
\end{tabular}


Tabulka 12: Abs. a rel. KADDS skór - subškála Symptomy \& diagnostika (9 pol.)

\begin{tabular}{|c|c|c|c|c|c|c|c|}
\hline & \multicolumn{7}{|c|}{ KADDS skór subškály Symptomy \& diagnostika $\left(\mathrm{N}_{\mathrm{R}}=240\right.$ resp.) } \\
\hline & $\varnothing[N]$ & SD $[N]$ & $\min .[N]$ & $\max .[\mathrm{N}]$ & mod. [N] & med. $[\mathrm{N}]$ & abs. $\left[\mathrm{N}_{\mathrm{R}}\right]$ \\
\hline Absolutní & 6,2 & 1,5 & 1 & 9 & 7 & 6 & 240 \\
\hline & $\varnothing[\%]$ & SD [\%] & $\min .[\%]$ & $\max .[\%]$ & mod. [\%] & med. [\%] & abs. $\left[\mathrm{N}_{\mathrm{R}}\right]$ \\
\hline Relativní & 69,3 & 17,2 & 11 & 100 & 78 & 67 & 240 \\
\hline
\end{tabular}

Tabulka 13: Abs. a rel. KADDS skór - subškála Intervence \& terapie (12 pol.)

\begin{tabular}{|c|c|c|c|c|c|c|c|}
\hline & \multicolumn{7}{|c|}{ KADDS skór subškály Intervence \& terapie $\left(\mathrm{N}_{\mathrm{R}}=240\right.$ resp. $)$} \\
\hline & $\varnothing[N]$ & SD $[N]$ & $\min .[N]$ & $\max .[\mathrm{N}]$ & mod. $[\mathrm{N}]$ & med. [N] & abs. $\left[\mathrm{N}_{\mathrm{R}}\right]$ \\
\hline Absolutní & 5,0 & 2,0 & 0 & 11 & 5 & 5 & 240 \\
\hline & $\varnothing[\%]$ & SD [\%] & $\min .[\%]$ & $\max .[\%]$ & mod. [\%] & med. [\%] & abs. $\left[\mathrm{N}_{\mathrm{R}}\right]$ \\
\hline Relativní & 41,8 & 16,6 & 0 & 92 & 42 & 42 & 240 \\
\hline
\end{tabular}

Tabulka 14: KADDS - vzájemné porovnání subškál a celé škály

\begin{tabular}{|c|c|c|c|c|c|c|c|}
\hline \multirow[b]{2}{*}{ subškála } & \multicolumn{7}{|c|}{ Relativní KADDS skór subškály a celá škála $\left(N_{R}=240\right.$ resp.) } \\
\hline & $\varnothing[\%]$ & SD [\%] & $\min .[\%]$ & max. [\%] & mod. [\%] & med. [\%] & abs. $\left[\mathrm{N}_{\mathrm{R}}\right]$ \\
\hline Všeobecně o ADHD & 48,1 & 15,6 & 7 & 87 & 60 & 47 & 240 \\
\hline Symptomy \& diagn. & 69,3 & 17,2 & 11 & 100 & 78 & 67 & 240 \\
\hline Intervence \& terapie & 41,8 & 16,6 & 0 & 92 & 42 & 42 & 240 \\
\hline Celá škála & 51,3 & 12,4 & 11 & 83 & 61 & 53 & 240 \\
\hline
\end{tabular}

Z provedených výpočtů vyplývá, že se znalosti respondentů zahrnuté do subškál Všeobecně o ADHD, Symptomy \& diagnostika a Intervence \& terapie statisticky významně liší. Bylo zjištěno, že nejhorší znalosti o ADHD mají respondenti v oblasti zaměřené na Intervenci \& terapii, znalosti z oblasti V̌̌eobecně o $A D H D$ jsou mírně lepší a srovnatelné s průměrnými znalostmi celé KADDS škály a nejlepší znalosti respondenti vykazují v oblasti Symptomů \& diagnostiky. Tyto výsledky lze interpretovat tak, že učitelé jsou lépe informováni o symptomech ADHD, tj. mohli by mít větší úspěšnost při jejich rozpoznávání a doporučování odborného speciálně pedagogického vyšetření. Jejich znalosti potřebné ke specifické speciálně pedagogické intervenci jsou však statisticky významně horší, což naznačuje existenci určitých rezerv v jejich vlastní pedagogické praxi a potřebu jejich dalšího vzdělávání. Proto jsou součástí této knihy také kapitoly zaměřené na 
pedagogickou a speciálně pedagogickou intervenci zaměřenou na žáka s ADHD.

Nebyla zjištěna prokazatelná vzájemná závislost mezi KADDS skóry jednotlivých subškál, hodnoty korelačních koeficientů naznačují nízkou vzájemnou závislost subškál Symptomy \& diagnostika a Intervence \& terapie (tzv. nepř́liš těsný vztah, $r=0,24$ ), viz také graf 14 . Vzájemné korelace zbývajících subškál jsou na hranici mezi nízkou a střední závislostí - hodnota korelačního koeficientu činí v obou případech $r \approx 0,4$. Tento výsledek lze interpretovat např. tak, že znalosti učitelů nejsou př́liš systematické a vykazují značnou roztříštěnost, nebot i relativně dobrá teoretická znalost problematiky ještě neznamená schopnost provádět intervenci. Pro jejich hodnocení je tedy v podmínkách České republiky vhodné použít celou škálu KADDS, která má větší počet položek, lepší statistické parametry a tím i lepší vypovídací schopnost než mají samostatné dílčí subškály Všeobecně o ADHD, Symptomy \& diagnostika a Intervence \& terapie.

Souhrnně tedy lze konstatovat, že celkový KADDS skór a KADDS skóry jednotlivých subškál, tj. znalosti respondentů o ADHD se v jednotlivých oblastech:

- statisticky významně liší,

- znalosti v dílčích oblastech silně korelují s celkovými znalostmi,

- znalosti v dílčích oblastech příliš nekorelují navzájem.

Vzhledem $\mathrm{k}$ výše uvedeným závěrům jsme se nadále omezili na zjištování závislosti celkového KADDS skóru na nezávislých faktorech, např. vzdělání respondenta, pracouní zařazení respondenta, typ školy, na které respondent pracuje, zkušenost respondenta $s$ žáky s ADHD, zkušenosti respondenta s jedinci s ADHD (př́buzní a známí), sebehodnocení znalostí respondenta o ADHD a potřeba dalšího sebevzdělávání. 


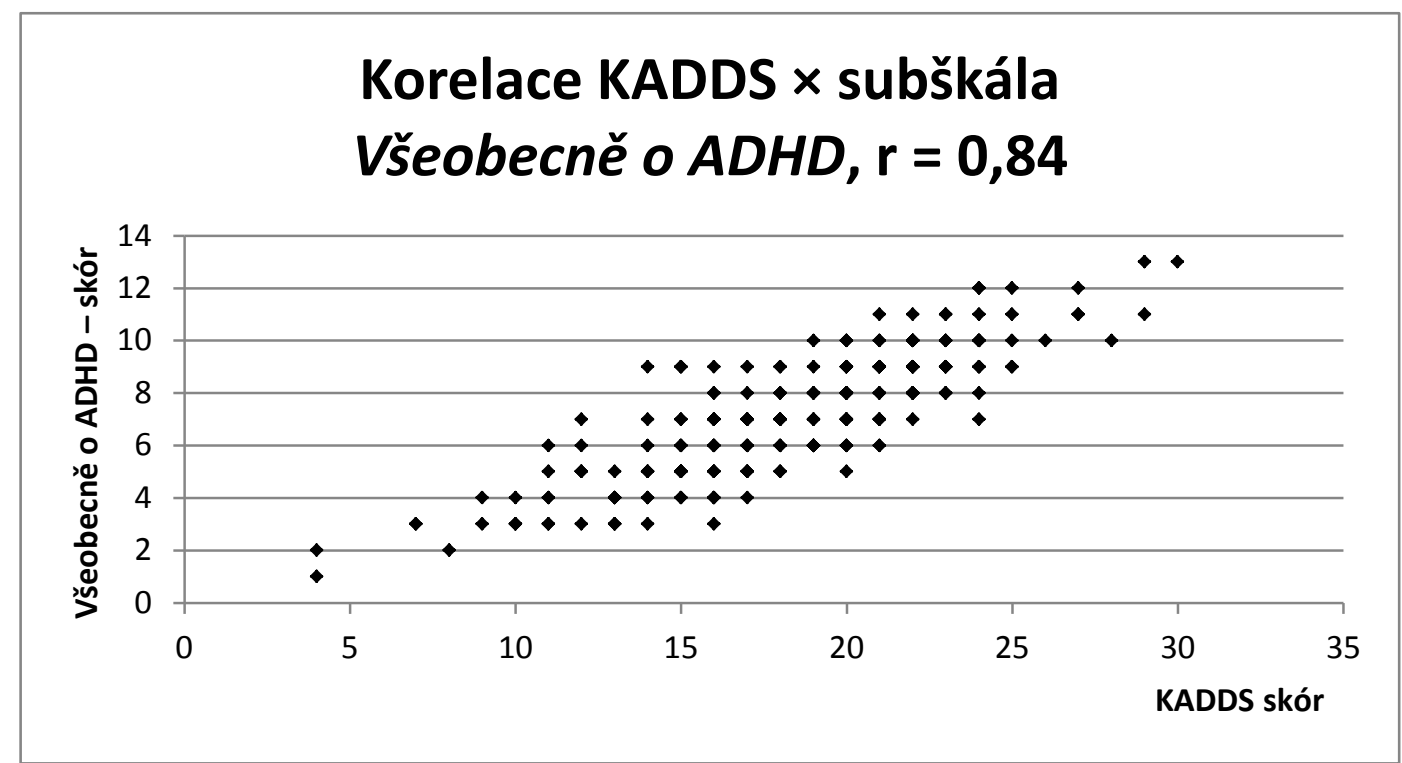

Graf 11: Korelace KADDS × subškála V̌̌eobecně o $A D H D$

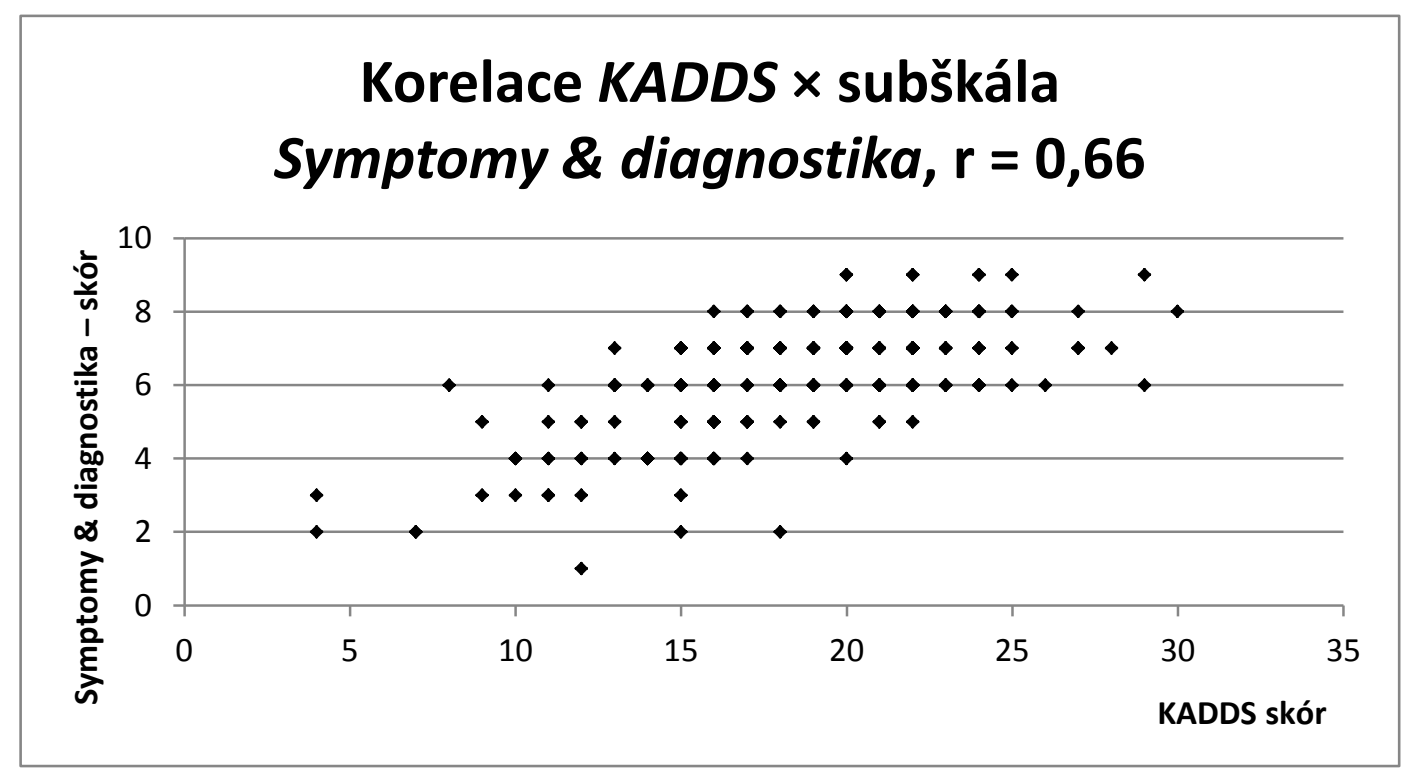

Graf 12: Korelace KADDS × subškála Symptomy \& diagnostika 


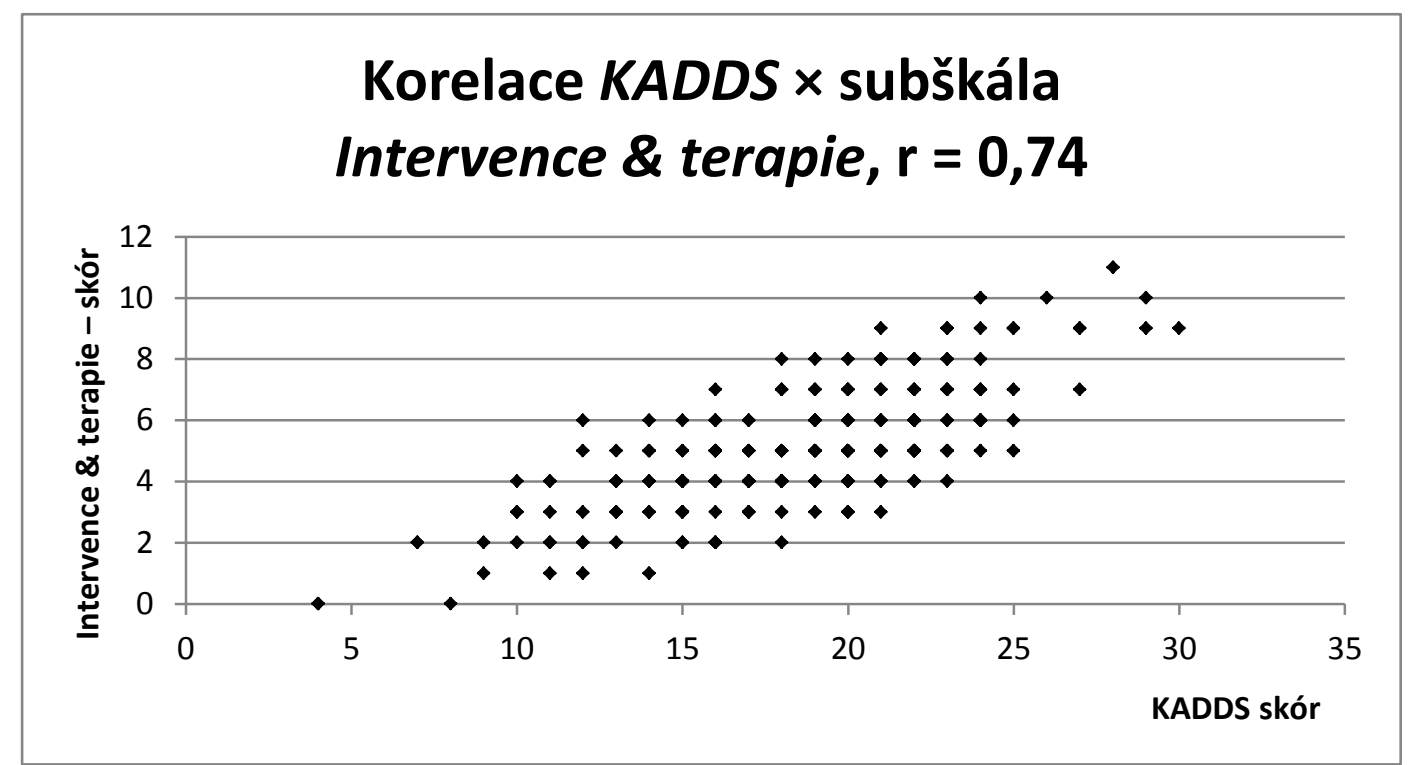

Graf 13: Korelace KADDS × subškála Intervence \& terapie

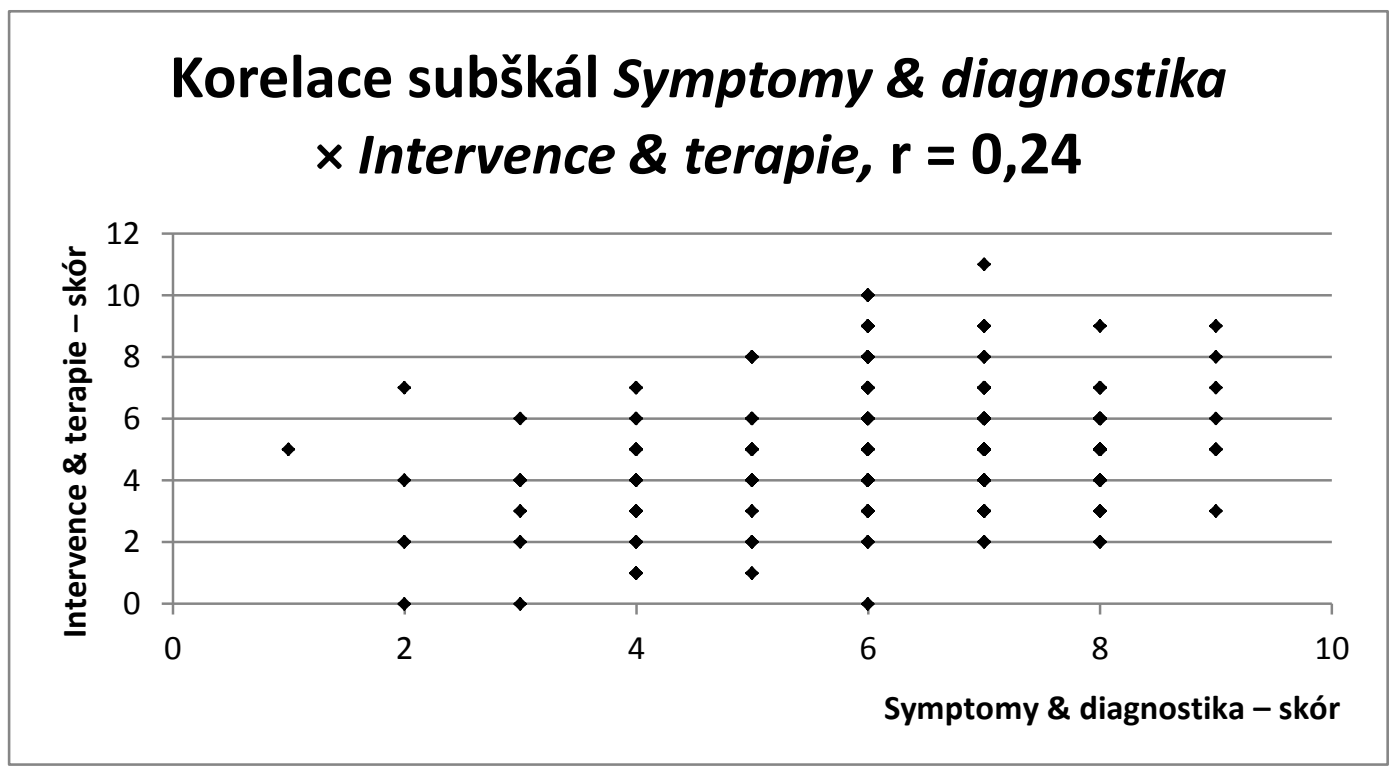

Graf 14: Korelace subškál Symptomy \& diagnostika $\times$ Intervence \& terapie

\subsubsection{Reliabilita KADDS skórů}

Hodnocení reliability získaných dat pomocí koeficientu Cronbachovo alfa $a_{C}$ naznačuje horší vnitřní soudržnost dat dosaženou při výzkumu UJEP 2014, než bylo nakonec dosaženo při přípravě nástroje KADDS (Sciutto 2000b), viz tabulka 15. Význam hodnot koeficientu Cronbachovo alfa $a_{c}$ při hodnocení reliability však nelze přeceňovat. 
Nelze jej správně interpretovat bez znalostí dalších okolností, resp. podmínek výzkumných šetření, které jej mohou ovlivňovat. Lze jej považovat pouze za dolní mez odhadu reliability a ve výzkumu UJEP 2014 byl použit zejména $\mathrm{z}$ důvodu kompatibility s ostatními výzkumy publikovanými vliteratuře, viz kapitola 8.1 .1 Posuzovací škála KADDS.

Tabulka 15: Reliabilita dat celkového KADDS skóru a skórů jednotlivých subškál

\begin{tabular}{|l|c|c|}
\hline & \multicolumn{2}{|c|}{ Relaliabilita - Cronbachovo alfa $\alpha_{C}\left(N_{R}=240\right.$ resp.) } \\
\hline \multicolumn{1}{|c|}{ subškála } & $\alpha_{C}$ (UJEP, $N_{R}=240$ resp.) & $\alpha_{C}$ (Sciutto 2000a, $N_{R}=149$ resp.) \\
\hline Všeobecně o ADHD & 0,47 & \multirow{2}{*}{0,71} \\
\hline Symptomy \& diagn. & 0,51 & \\
\hline Intervence \& terapie & 0,52 & 0,86 \\
\hline Celá škála & 0,70 & 0,86 \\
\hline
\end{tabular}

\subsubsection{KADDS skóry různých skupin respondentů}

Data zjištěná při provedeném šetření byla dále analyzována s cílem určit ty skupiny respondentů, u kterých jsou výsledky KADDS skórů nejhorší, resp. naopak nejlepší. Proto byly analyzovány závislosti KADDS skórů na nezávislých proměnných, tj. na kategoriích respondentů rozdělených do skupin podle toho, jak respondenti sami sebe označili v popisné části dotazníku. Byly analyzovány následující závislosti:

- Vzdělání respondenta × celkový relativní KADDS skór (viz tabulka 14).

- Pracovní zařazení respondenta $\times$ celkový relativní KADDS skór (viz tabulka 15).

- Typ školy, na které respondent pracuje $\times$ celkový relativní KADDS skór (viz tabulka 16).

- Zkušenost respondenta $\mathrm{s}$ žáky $\mathrm{s}$ ADHD $\times$ celkový relativní KADDS skór (viz tabulka 17).

- Zkušenost respondenta s jedinci s ADHD mezi př́íbuznými nebo přáteli × celkový relativní KADDS skór (viz tabulka 18). 
- Sebehodnocení vlastních znalostí respondenta o ADHD × celkový relativní KADDS skór (viz tabulka 19).

- Potřeba sebevzdělávání ADHD × celkový relativní KADDS skór (viz tabulka 20).

Na pětiprocentní ( $\alpha=5 \%)$ i jednoprocentní $(\alpha=1 \%)$ hladině spolehlivosti byla testována nulová hypotéza o rovnosti mediánů KADDS skórů respondentů zařazených do jednotlivých kategorií nezávislých proměnných s tím, že v případě, kdy nulovou hypotézu zamítnout nelze (tj. nulová hypotéza platí) a rozdíly KASSD skórů jednotlivých kategorií respondentů nejsou statisticky významné, nelze takové skupiny použít pro seřazení respondentů podle kategorie od nejhorších po nejlepší. Naopak v případě vyvrácení této hypotézy se KADDS skóry jednotlivých kategorií respondentů statisticky významně liší a seřazení lze provést. Následně pak lze např. identifikovat ty kategorie respondentů, u kterých by další vzdělávání mohlo mít největší přínos pro inkluzivní vzdělávání.

Matematicko-statistický postup zpracování byl tedy u jednotlivých skupin analogický:

1. Nejprve byla testována nulová hypotéza o rovnosti KADDS skórů jednotlivých kategorií respondentů ve skupinách.

2. Následně byly vypočteny a tabelovány hodnoty relevantních veličin popisné statistiky pro jednotlivé kategorie a skupiny.

3. V případě vyvrácení hypotézy o rovnosti KADDS skórů bylo stanoveno pořadí jednotlivých kategorií ve skupinách.

4. Zjištění bylo doplněno slovním komentářem a interpretací.

\subsubsection{Závislost KADDS skóru na vzdělání respondenta}

Byla testována nulová hypotéza $\mathrm{H}_{1} 0$ : Rozdíly KADDS skórů kategorií respondentů dle tabulky 16 nejsou statisticky významné. Tato hypotéza byla zamítnuta (hladina významnosti Kruskal-Wallisova testu $\mathrm{p}=0,0001)$, tj. platí alternativní hypotéza $\mathrm{H}_{1} 1$ : Rozdíly KADDS skórů kategorií respondentů dle tabulky 16 jsou statisticky významné. Průměrné KADDS skóry a další veličiny popis- 
né statistiky jsou uvedeny v tabulce 16. Z matematicko-statistické analýzy vyplývá, že nejhorší vědomosti o $\mathrm{ADHD}$ měli respondenti se středoškolským vzděláním, následovala kategorie $\mathrm{s}$ magisterským vysokoškolským vzděláním a nejlepších výsledků dosáhli respondenti kategorie s bakalářským, resp. vyšším odborným vzděláním, viz tabulka 16.

Tabulka 16: Vzdělání respondenta $\times$ celkový relativní KADDS skór

\begin{tabular}{|l|c|r|r|r|r|r|r|}
\hline & \multicolumn{7}{|c|}{ KADDS skór $\left(\mathrm{N}_{\mathrm{R}}=240\right.$ respondentů) } \\
\hline Nejvyšší dos. vzdělání & $\varnothing[\%]$ & \multicolumn{1}{|c|}{ SD [\%] } & min. [\%] & max. [\%] & mod. [\%] & med. [\%] & abs. [N $\mathrm{N}_{\mathrm{R}}$ ] \\
\hline SŠ & 46,9 & 10,0 & 25 & 83 & 50 & 47 & 76 \\
\hline Bc/VOŠ/DPS & 55,6 & 13,3 & 22 & 81 & 64 & 60 & 21 \\
\hline VŠ & 52,7 & 12,8 & 11 & 81 & 56 & 56 & 143 \\
\hline Celý soubor & 51,3 & 12,4 & 11 & 83 & 61 & 53 & 240 \\
\hline
\end{tabular}

Ukazuje se tedy jako žádoucí nastavit preference potřeby dalšího vzdělávání o problematice ADHD v rostoucím pořadí od skupiny se středoškolským vzděláním přes skupinu s vysokoškolským vzděláním. Skupina kategorie Bc/VOŠ/DPS není z tohoto hlediska aktuálně prioritní. Současně lze konstatovat, že relativní zastoupení této kategorie je mezi pedagogickými pracovníky je malé.

\subsubsection{Závislost KADDS skóru na pracovním zar̆azení respondenta}

Byla testována nulová hypotéza $\mathrm{H}_{2} 0$ : Rozdíly KADDS skórů kategorií respondentů dle tabulky 17 nejsou statisticky významné. Tato hypotéza byla zamítnuta (hladina významnosti Kruskal-Wallisova testu $\mathrm{p}=0,0071)$, tj. platí alternativní hypotéza $\mathrm{H}_{2} 1$ : Rozdíly KADDS skórů kategorií respondentů dle tabulky 17 jsou statisticky významné. Průměrné KADDS skóry a další veličiny popisné statistiky jsou uvedeny $\mathrm{v}$ tabulce 17 . Z matematicko-statistické analýzy vyplývá, že nejhorší vědomosti o ADHD měli pedagogové pracovně zařazení jako učitelé / učitelky v mateřských školách a jako učitelé / učitelky na 2. stupni základních škol. Naopak nejlepší výsledky 
měli vedoucí pedagogičtí pracovníci a odborní pracovníci se speciálně pedagogickým a/nebo psychologickým vzděláním, viz tabulka 17.

Tabulka 17: Pracovní zařazení respondenta $\times$ celkový relativní KADDS skór

\begin{tabular}{|l|r|r|r|r|r|r|r|}
\hline & \multicolumn{7}{|c|}{ KADDS skór ( $\mathrm{N}_{\mathrm{R}}=240$ respondentů) } \\
\hline Zařazení respondenta & \multicolumn{1}{|c|}{$\varnothing[\%]$} & \multicolumn{1}{c|}{ SD [\%] } & min. [\%] & max. [\%] & mod. [\%] & med. [\%] & abs. [N $\mathrm{N}_{\mathrm{R}}$ ] \\
\hline Učitel(ka) MŠ & 48,3 & 9,9 & 25 & 69 & 47 & 49 & 80 \\
\hline Učitel(ka) ZŠ 1. st. & 54,8 & 10,9 & 19 & 83 & 61 & 56 & 58 \\
\hline Učitel(ka) ZŠ 2. st. & 49,4 & 14,6 & 11 & 81 & 44 & 50 & 65 \\
\hline Vychovatel(ka) & 52,5 & 9,5 & 31 & 64 & 58 & 57 & 12 \\
\hline Spec. pedagog(žka) & 58,3 & 18,3 & 33 & 81 & nedef. & 63 & 8 \\
\hline Ředitel(ka) & 56,0 & 10,7 & 42 & 75 & 53 & 53 & 17 \\
\hline Celý soubor & 51,3 & 12,4 & 11 & 83 & 61 & 53 & 240 \\
\hline
\end{tabular}

Ukazuje se tedy jako žádoucí nastavit preference potřeby dalšího vzdělávání o problematice $\mathrm{ADHD}$ v rostoucím pořadí ve skupinách pedagogů pracovně zařazených jako učitelé / učitelky mateřských škol, učitelé / učitelky 2. stupně základních škol a učitelé / učitelky 1. stupně základních škol. Vedoucí pedagogičtí pracovníci a odborní pracovníci se speciálně pedagogickým a/nebo psychologickým vzděláním dosáhli relativně vysokých KADDS skórů, čemuž by mělo odpovídat zaměření jejich případného dalšího vzdělávání na více specializované problémy vzdělávání žáků s ADHD. Podobně specifickou kategorií jsou vychovatelé, kteří dosahují střední úrovně vědomostí o poruše $\mathrm{ADHD}$ a v rámci mimoškolní činnosti by se mohli zaměřit na některé intervenční strategie u žáků s ADHD.

Druh školy, na které respondent působí, dobře koreluje s jeho pracovním zařazením a také s jeho nejvyšším dosaženým vzděláním.

\subsubsection{Závislost KADDS skóru na typu školy, na které respondent pracuje}

Byla testována nulová hypotéza $\mathrm{H}_{3} 0$ : Rozdíly KADDS skórů kategorií respondentů dle tabulky 18 nejsou statisticky významné. Tato hypotéza byla zamítnuta (hladina významnosti Kruskal-Walli- 
sova testu $\mathrm{p}<0,0001)$, tj. platí alternativní hypotéza $\mathrm{H}_{3} 1$ : Rozdíly KADDS skórů kategorií respondentů dle tabulky 18 jsou statisticky významné. Průměrné KADDS skóry a další veličiny popisné statistiky jsou uvedeny $\mathrm{v}$ tabulce 18. Z matematicko-statistické analýzy vyplývá, že nejhorší vědomosti o ADHD měli pedagogové působící v mateřských školách a na 2. stupni základních škol. Lepších výsledků dosáhli učitelé / učitelky na 1. stupni základních škol a nejlepší výsledky měli pedagogové působící na základních školách praktických, viz tabulka 18.

Tabulka 18: Typ školy, na které respondent pracuje $\times$ celk. rel. KADDS skór

\begin{tabular}{|l|r|r|r|r|r|r|r|}
\hline & \multicolumn{7}{|c|}{ KADDS skór $\left(\mathrm{N}_{\mathrm{R}}=240\right.$ respondentů) } \\
\hline Typ školy respondenta & \multicolumn{1}{|c|}{$\phi[\%]$} & \multicolumn{1}{c|}{ SD [\%] } & min. [\%] & max. [\%] & mod. [\%] & med. [\%] & abs. [N $\mathrm{N}_{\mathrm{R}}$ ] \\
\hline MŠ & 48,3 & 10,0 & 25 & 69 & 47 & 47 & 93 \\
\hline ZŠ 1. stupeň & 55,3 & 10,2 & 19 & 83 & 61 & 57 & 72 \\
\hline ZŚ 2. stupeň & 49,5 & 13,8 & 11 & 81 & 44 & 50 & 67 \\
\hline ZŠ praktická & 69,8 & 8,7 & 56 & 81 & 75 & 74 & 8 \\
\hline Celý soubor & 51,3 & 12,4 & 11 & 83 & 61 & 53 & 240 \\
\hline
\end{tabular}

Uvedené výsledky jsou v dobrém souhlasu sýsledky korelace KADDS skóru s pracovním zařazením respondenta popsanými v předchozím oddíle 7.3.3.2 a potvrzují prioritu zaměření dalšího vzdělávání na učitele / učitelky mateřských škol a učitele 2. stupně základních škol.

\subsubsection{Závislost KADDS skóru na zkušenostech s žáky s ADHD}

Byla testována nulová hypotéza $\mathrm{H}_{4} 0$ : Rozdíly KADDS skórů kategorií respondentů dle tabulky 19 nejsou statisticky významné. Tato hypotéza byla zamítnuta (hladina významnosti Kruskal-Wallisova testu $\mathrm{p}=0,0258$ ), tj. platí alternativní hypotéza $\mathrm{H}_{3} 1$ : Rozdíly KADDS skórů kategorií respondentů dle tabulky 19 jsou statisticky významné. Současně však bylo zjištěno, že mediánový test nevede k zamítnutí hypotézy $\mathrm{H}_{4} 0$. Průměrné KADDS skóry a další veličiny popisné statistiky jsou uvedeny v tabulce 19 . Z matematicko- 
statistické analýzy vyplývá, že standardními metodami nelze u skupiny respondentů kategorizované podle počtu žáků s ADHD, se kterými se ve své pedagogické praxi setkali, hypotézu potvrdit ani zamítnout na obvyklých hladinách spolehlivosti. Kritérium zkušeností se žáky s ADHD tedy nepovažujeme za vhodné např. pro stanovení priorit dalšího vzdělávání o poruše ADHD.

Tabulka 19: Zkušenosti s žáky s ADHD × celkový relativní KADDS skór

\begin{tabular}{|l|r|r|r|r|r|r|r|}
\hline & \multicolumn{7}{|c|}{ KADDS skór $\left(\mathrm{N}_{\mathrm{R}}=240\right.$ respondentů) } \\
\hline Počet dětí s ADHD & \multicolumn{1}{|c|}{$\varnothing \%]$} & \multicolumn{1}{c|}{ SD [\%] } & min. [\%] & max. [\%] & mod. [\%] & med. [\%] & abs. [N $\left.\mathrm{N}_{\mathrm{R}}\right]$ \\
\hline 0 & 43,3 & 13,3 & 19 & 61 & 47 & 46 & 18 \\
\hline 1 & 42,8 & 12,5 & 25 & 67 & 56 & 50 & 22 \\
\hline $2-5$ & 51,7 & 11,4 & 25 & 81 & 58 & 53 & 66 \\
\hline Více než 5 & 53,1 & 12,2 & 11 & 83 & 61 & 53 & 134 \\
\hline Celý soubor & 51,3 & 12,4 & 11 & 83 & 61 & 53 & 240 \\
\hline
\end{tabular}

\subsubsection{Závislost KADDS skóru na zkušenostech $\mathrm{s}$ jedinci s ADHD}

Byla testována nulová hypotéza $\mathrm{H}_{5} 0$ : Rozdíly KADDS skórů kategorií respondentů dle tabulky 20 nejsou statisticky významné. Tuto hypotézu nelze zamítnout (hladina významnosti Kruskal-Wallisova testu $\mathrm{p}=0,7703)$, tj. lze konstatovat, že rozdíly KADDS skórů respondentů, kteří se liší zkušenostmi s jedinci s ADHD mezi příbuznými nebo přáteli, nejsou statisticky významné. Průměrné KADDS skóry a další veličiny popisné statistiky jsou uvedeny v tabulce 20 .

Tabulka 20: Jedinec s ADHD mezi příbuzn. nebo přáteli $\times$ celk. rel. KADDS skór

\begin{tabular}{|c|c|c|c|c|c|c|c|}
\hline & \multicolumn{7}{|c|}{ KADDS skór $\left(\mathrm{N}_{\mathrm{R}}=240\right.$ respondentů $)$} \\
\hline Jedinec s ADHD v okolí & $\varnothing[\%]$ & SD [\%] & $\min .[\%]$ & $\max .[\%]$ & mod. [\%] & med. [\%] & abs. $\left[N_{R}\right]$ \\
\hline Ano & 52,2 & 14,7 & 11 & 83 & 61 & 50 & 50 \\
\hline $\mathrm{Ne}$ & 51,1 & 11,7 & 11 & 81 & 56 & 53 & 188 \\
\hline Neuvedeno & 54,2 & 1,4 & 53 & 56 & nedef. & 54 & 2 \\
\hline Celý soubor & 51,3 & 12,4 & 11 & 83 & 61 & 53 & 240 \\
\hline
\end{tabular}


Kritérium zkušeností pedagoga s jedinci s ADHD, se kterými se setkává $\mathrm{v}$ rodině nebo mezi přáteli, nelze považovat za vhodné pro hodnocení znalostí respondentů o poruše ADHD.

\subsubsection{Závislost KADDS skóru na sebehodnocení}

Byla testována nulová hypotéza $\mathrm{H}_{6} 0$ : Rozdíly KADDS skórů kategorií respondentů dle tabulky 21 nejsou statisticky významné. Tato hypotéza byla zamítnuta (hladina významnosti Kruskal-Wallisova testu $\mathrm{p}=0,00081$ ), tj. platí alternativní hypotéza $\mathrm{H}_{6} 1$ : Rozdíly KADDS skórů kategorií respondentů dle tabulky 21 jsou statisticky významné. Průměrné KADDS skóry a další veličiny popisné statistiky jsou uvedeny v tabulce 21. Z matematicko-statistické analýzy vyplývá, že respondenti, kteří považují své znalosti o poruše ADHD za nedostačující, mají obvykle pravdu a jejich KADDS skór je statisticky významně horší než KADDS skór respondentů, kteří považují své znalosti o poruše ADHD za nedostačující.

Tabulka 21: Sebehodnocení vlastních znalostí o ADHD $\times$ celk. rel. KADDS skór

\begin{tabular}{|l|r|r|r|r|r|r|r|}
\hline & \multicolumn{7}{|c|}{ KADDS skór ( $\mathrm{N}_{\mathrm{R}}=240$ respondentů) } \\
\hline \multicolumn{1}{|c|}{ Sebehodnocení } & \multicolumn{1}{|c|}{$\phi[\%]$} & \multicolumn{1}{c|}{ SD [\%] } & min. [\%] & max. [\%] & mod. [\%] & med. [\%] & abs. [N $\left.\mathrm{N}_{\mathrm{R}}\right]$ \\
\hline Dostačující & 54,2 & 11,7 & 19 & 83 & 53 & 56 & 131 \\
\hline Nedostačující & 48,3 & 12,5 & 11 & 81 & 44 & 47 & 98 \\
\hline Neuvedeno & 45,8 & 9,7 & 31 & 61 & 56 & 44 & 11 \\
\hline Celý soubor & 51,3 & 12,4 & 11 & 83 & 61 & 53 & 240 \\
\hline
\end{tabular}

Kritérium sebehodnocení tedy lze využít při volbě cílové skupiny pedagogů pro další vzdělávání o poruše ADHD s tím závěrem, že by měli být preferováni ti, kteří považují své znalosti za nedostačující. Ukazuje se však, že hodnocení vlastních znalostí nekoreluje s názorem respondenta na potřebu dalšího sebevzdělávání, viz následující oddíl 8.3.3.7. 


\subsubsection{Závislost KADDS skóru na potřebě dalšího sebevzdělávání}

Byla testována nulová hypotéza $\mathrm{H}_{7} 0$ : Rozdíly KADDS skórů kategorií respondentů dle tabulky 22 nejsou statisticky významné. Tuto hypotézu nelze zamítnout (hladina významnosti Kruskal-Wallisova testu $\mathrm{p}=0,60502)$, tj. lze konstatovat, že rozdíly KADDS skórů respondentů, kteří se liší svou vnitřní potřebou dále se vzdělávat o poruše ADHD, nejsou statisticky významné. Průměrné KADDS skóry a další veličiny popisné statistiky jsou uvedeny v tabulce 22 .

Tabulka 22: Potřeba sebevzdělávání $\times$ celkový relativní KADDS skór

\begin{tabular}{|l|r|r|r|r|r|r|r|}
\hline & \multicolumn{7}{|c|}{ KADDS skór $\left(\mathrm{N}_{\mathrm{R}}=240\right.$ respondentů) } \\
\hline Potřeba sebevzdělávání & $\varnothing[\%]$ & \multicolumn{1}{|c|}{ SD [\%] } & min. [\%] & max. [\%] & mod. [\%] & med. [\%] & abs. [N $\mathrm{N}_{\mathrm{R}}$ ] \\
\hline $\mathrm{Ne}$ & 50,1 & 15,2 & 11 & 81 & 58 & 51 & 42 \\
\hline Ano & 51,9 & 11,5 & 11 & 83 & 56 & 53 & 190 \\
\hline Neuvedeno & 43,4 & 11,4 & 25 & 61 & 47 & 46 & 8 \\
\hline Celý soubor & 51,3 & 12,4 & 11 & 83 & 61 & 53 & 240 \\
\hline
\end{tabular}

Kritérium potřeby sebevzdělávání tedy paradoxně není vhodné pro efektivní výběr pedagogů pro další vzdělávání o poruše ADHD. Výsledek lze interpretovat např. tak, že ti, kteří již mají znalosti lepší, mají také větší potřebu se dále vzdělávat, a naopak ti, kteří mají znalosti horší, tuto potřebu dalšího sebevzdělávání nemají...

\subsubsection{Dílčí shrnutí a doporučení pro pedagogickou praxi}

Ukázalo se, že výsledky KADDS skóru se statisticky významně liší ve skupinách pedagogů rozdělovaných podle následujících kategorií:

- dosažené vzdělání,

- pracovní zařazení,

- typ školy, na které pedagog pracuje,

- sebehodnocení vlastních znalostí o ADHD. 
Naopak, výsledky KADDS skóru se statisticky významně neliší (případně odlišnost není dostatečně prokazatelná) ve skupinách pedagogů rozdělovaných podle kategorií:

- zkušenost z pedagogické práce s žáky s ADHD,

- zkušenost s jedinci s ADHD mezi příbuznými nebo přáteli,

- potřeba dalšího sebevzdělávání o poruše ADHD.

Souhrnně tedy z výše uvedeného vyplývá, že byla potvrzena výchozí hypotéza H0: Mezi pedagogy mateřských a základnich škol lze nalézt takové skupiny, u kterých se teoretické vědomosti o vzdělávání žáků s ADHD statisticky významně liši. V těchto skupinách také byly identifikovány kategorie pedagogů, které by měly být prioritním cílem inkluzivního vzdělávání o poruše ADHD.

KADDS skór lze použít při hodnocení teoretických vědomostí pedagogů o ADHD. Na základě KADDS skóru konkrétního pedagoga lze formulovat doporučení o potřebě jeho dalšího teoretického vzdělávání o problematice ADHD. Ve skupinách pedagogů rozdělovaných podle vzdělání, pracovního zařazení a sebehodnocení vlastních znalostí se jeví jako prioritní vzdělávání pedagogů, kteří dosáhli jen středního vzdělání a/nebo působí v mateřských školách, případně těch, kteří hodnotí své vlastní vědomosti o ADHD jako nedostačující. KADDS skór není dobrým vodítkem při posuzování teoretických vědomostí pedagogů, jejichž primárním zdrojem informací o ADHD je jen kontakt s jedinci s diagnózou ADHD.

\subsection{4 Úspěšnost položek ve škále KADDS}

Z hlediska obtížnosti lze rozdělit položky škály KADDS různými zpơsoby. Jako jedna z možností se jeví stanovení úspěšnosti $\eta$ pro každou položku jako poměru počtu správných odpovědí (,,správně“) ku počtu všech možných odpovědí (součet „správně“ + „nesprávně“ + „nevím“). Takto stanovené relativní úspěšnosti jednotlivých položek škály KADDS jsou uvedeny v grafu 15. Vysoká úspěšnost pak odpovídá nízké obtížnosti a naopak. 


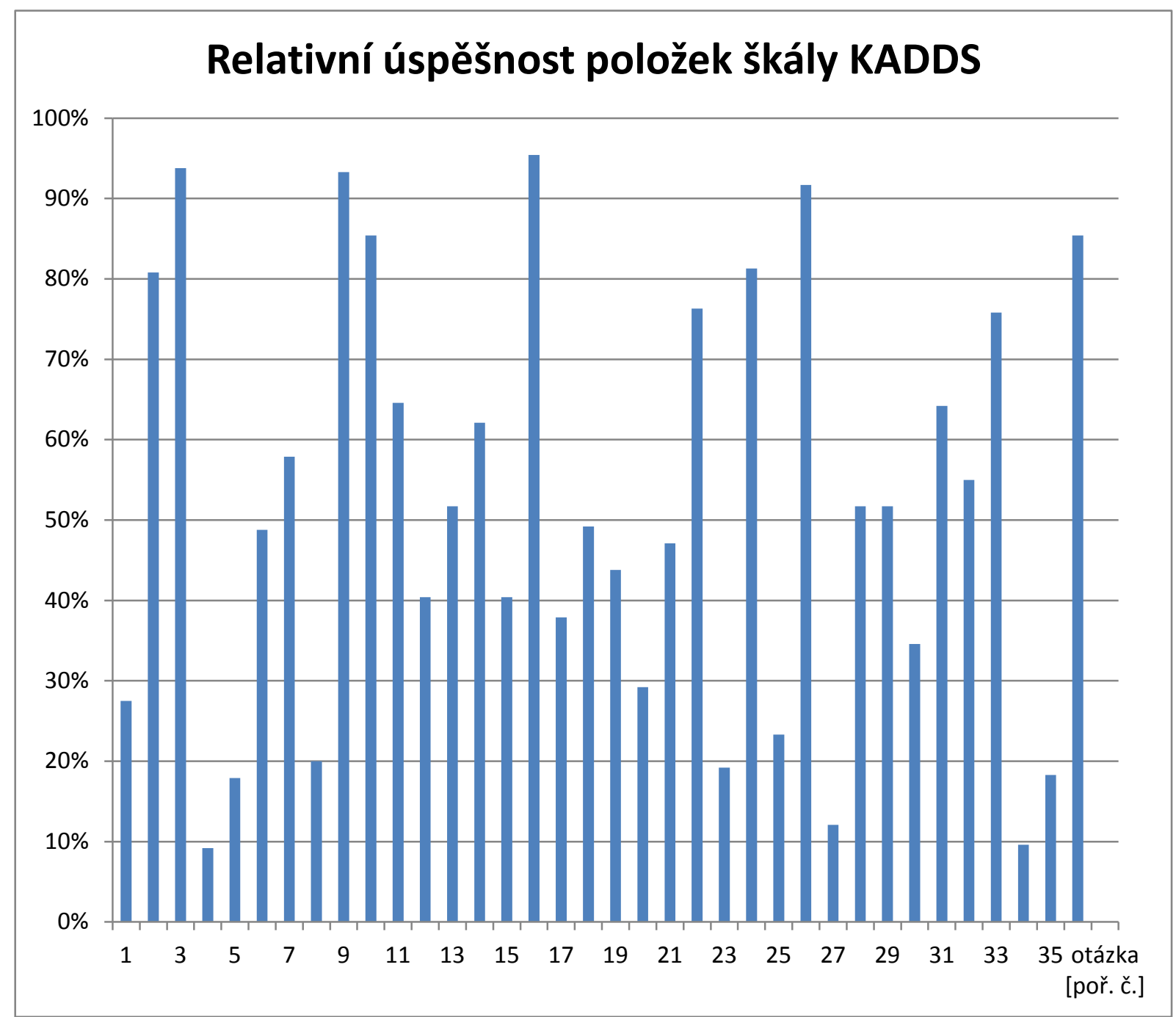

Graf 15: Relativní úspěšnost položek škály KADDS

Za účelem identifikace obtížných a málo obtížných položek bylo stanoveno kritérium úspěšnosti tak, že celé rozpětí 0-100 \% bylo rozděleno na třetiny, přičemž dolní třetina odpovídala málo úspěšným položkám, prostřední třetina středně úspěšným položkám a horní třetina úspěšným položkám. Pro identifikaci velmi úspěšných a velmi neúspěšných položek byla ještě na koncích celého intervalu stanovena $10 \%$ pásma. Úspěšnost jednotlivých položek škály KADDS je uvedena v tabulce 23. 
Tabulka 23: Úspěšnost položek škály KADDS

\begin{tabular}{|l|r|r|}
\hline & \multicolumn{2}{|c|}{ Úspěšnost položek škály KADDS } \\
\hline \multicolumn{1}{|c|}{ Úspěšnost } & \multicolumn{1}{|c|}{ Číslo položky } & \multicolumn{1}{c|}{ Kritérium } \\
\hline Velmi velká & $2,9,16,26$ & $\eta>90 \%$ \\
\hline Velká & $22,24,33,36$ & $90 \%>n>66,6 \%$ \\
\hline \multirow{2}{*}{ Střední } & $\begin{array}{r}1,7,11,12,13,14,15,17,18, \\
19,21,28,29,30,21,32\end{array}$ & $66,6 \%>n>33,3 \%$ \\
\hline Malá & $1,5,8,20,23,25,27,35$ & $33,3 \%>n>10 \%$ \\
\hline Velmi malá & 4,34 & $10 \%>n$ \\
\hline
\end{tabular}

Ukázalo se, že počet málo obtížných položek ( $\eta>66,6$ \%) i obtížných položek (n<33,3\%) je stejný (deset). Počet středně obtížných položek $(33,6 \%<\eta<66,6 \%)$ je vyšší (šestnáct). To svědčí o tom, že obtížnost otázek přiměřeně pokrývá celý rozsah 0-100 \%, žádný respondent však nedosáhl ani plné úspěšnosti (100\%), ani nulové úspěšnosti (0\%).

Na základě údajů uvedených v tabulce 23 a grafu 15 lze konstatovat, že pro respondenty byly nejtěžší, a tudíž i s nejhorším výsledkem zodpovězeny položky č. 4 a č 34 . Špatné výsledky měli respondenti také u položek č. 5, 8, 23 a 35, které všechny vykazují menší než $20 \%$ úspěšnost.

Respondenti tedy výrazně chybovali u výše uvedených položek, které obsahovaly následující tvrzení:

- Položka č. 4: Dítě $\mathrm{s} A D H D$ se typicky chová lépe v př́itomnosti otce než v přítomnosti matky (správná odpověd’ = ANO).

- Položka č. 5: Diagnózu ADHD je možno přidělit pouze v případě, že se symptomy poruchy projevovaly již před 7. rokem života dítěte (správná odpověd' = ANO).

- Položka č. 8: Antidepresiva jsou účinná při redukci symptomů ADHD u většiny dětí (správná odpověd’ = ANO).

- Položka č. 23: Diety s omezením cukru a potravinových aditiv jsou při redukci symptomů ADHD účinné (správná odpověd' $=\mathrm{NE}$ ). 
- Položka č. 34: Kognitivně-behaviorální/psychologická intervence je u dětí s ADHD primárně zaměřena na redukci symptomů poruchy pozornosti (správná odpověd' $=\mathrm{NE}$ ).

- Položka č. 35: Elektroterapie (např. léčba elektrickými šoky) je $\mathrm{v}$ těžkých případech ADHD účinná (správná odpověd’ $=\mathrm{NE}$ ).

Naopak nejvyšší úspěšnost měli respondenti při rozhodování u následujících položek:

- Položka č. 16: Hlavní symptomy ADHD jsou porucha pozornosti a impulzivita / hyperaktivita (správná odpověd' = ANO).

- Položka č. 3: Děti s ADHD se často nechají rozptylovat vnějšími podněty (správná odpověd' = ANO).

- Položka č. 9: Mají-li děti s ADHD sedět, často se vrtí a ošívají (správná odpověd' = ANO).

- Položka č. 26: Děti s ADHD mají často potíže s organizací a plněním svých úkolů a povinností (správná odpověd' = ANO).

- Položka č. 36: Péče o děti s ADHD primárně zaměřená na tresty je při redukci symptomů poruchy nejúčinnější (správná odpověd' $=\mathrm{NE}$ ).

- Položka č. 10: Jako nejefektivnější se při péči o děti s ADHD jeví kombinace speciálně pedagogického přístupu učitele, poučeného přístupu rodičů a medikace dítěte (správná odpověd' = ANO).

Grafy číslo 16-18 pak postupně znázorňují rozložení správných odpovědí celého souboru respondentů $\mathrm{v}$ oblasti všeobecných znalostí o ADHD (viz graf č. 16, subškála Všeobecně o $A D H D$ ), v oblasti diagnostiky (viz graf č. 17, subškála Symptomy \& diagnostika) a v oblasti intervence (viz graf č. 18, subškála Intervence \& terapie). 


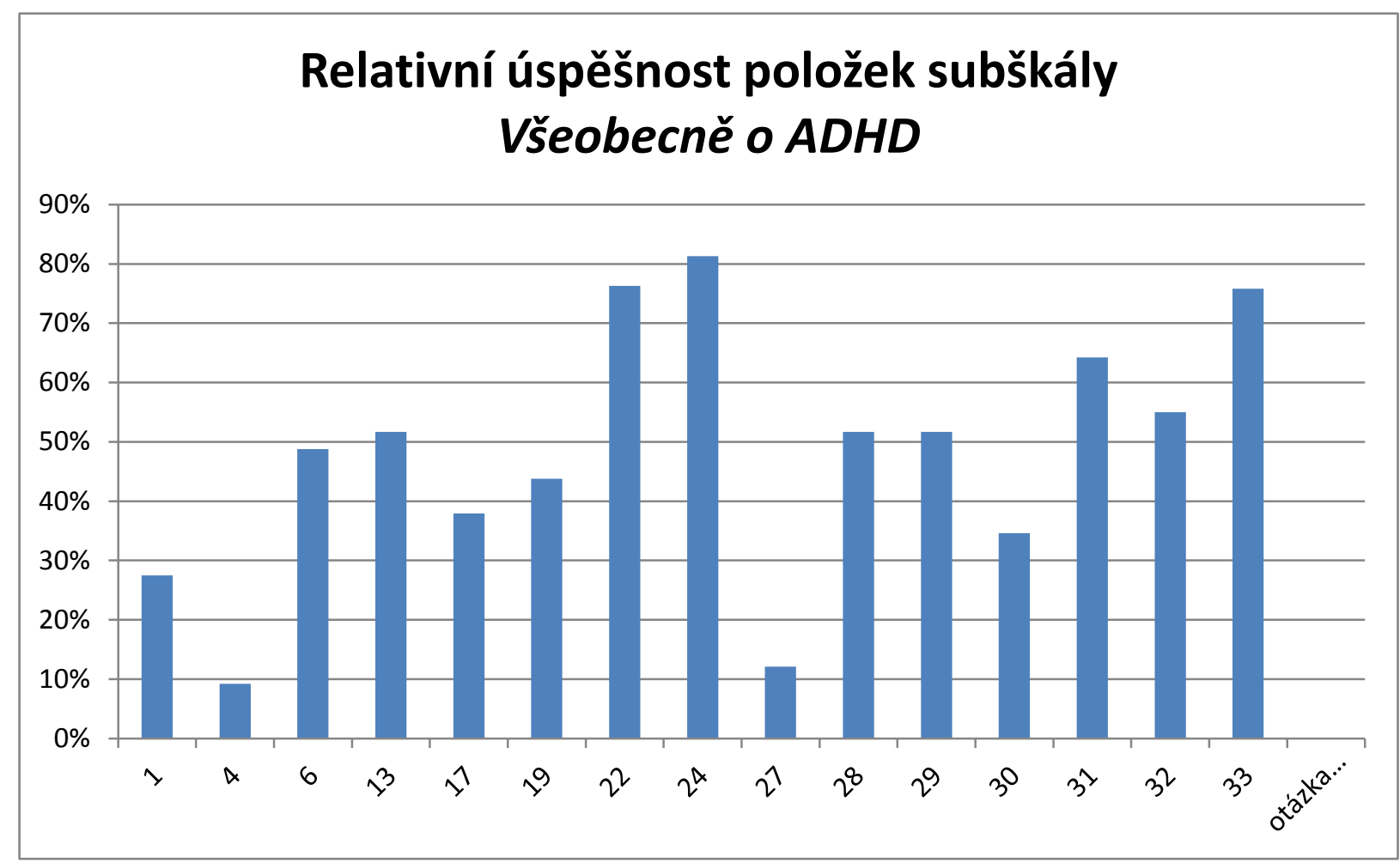

Graf 16: Relativní úspěšnost položek subškály V̌̌eobecně o $A D H D$

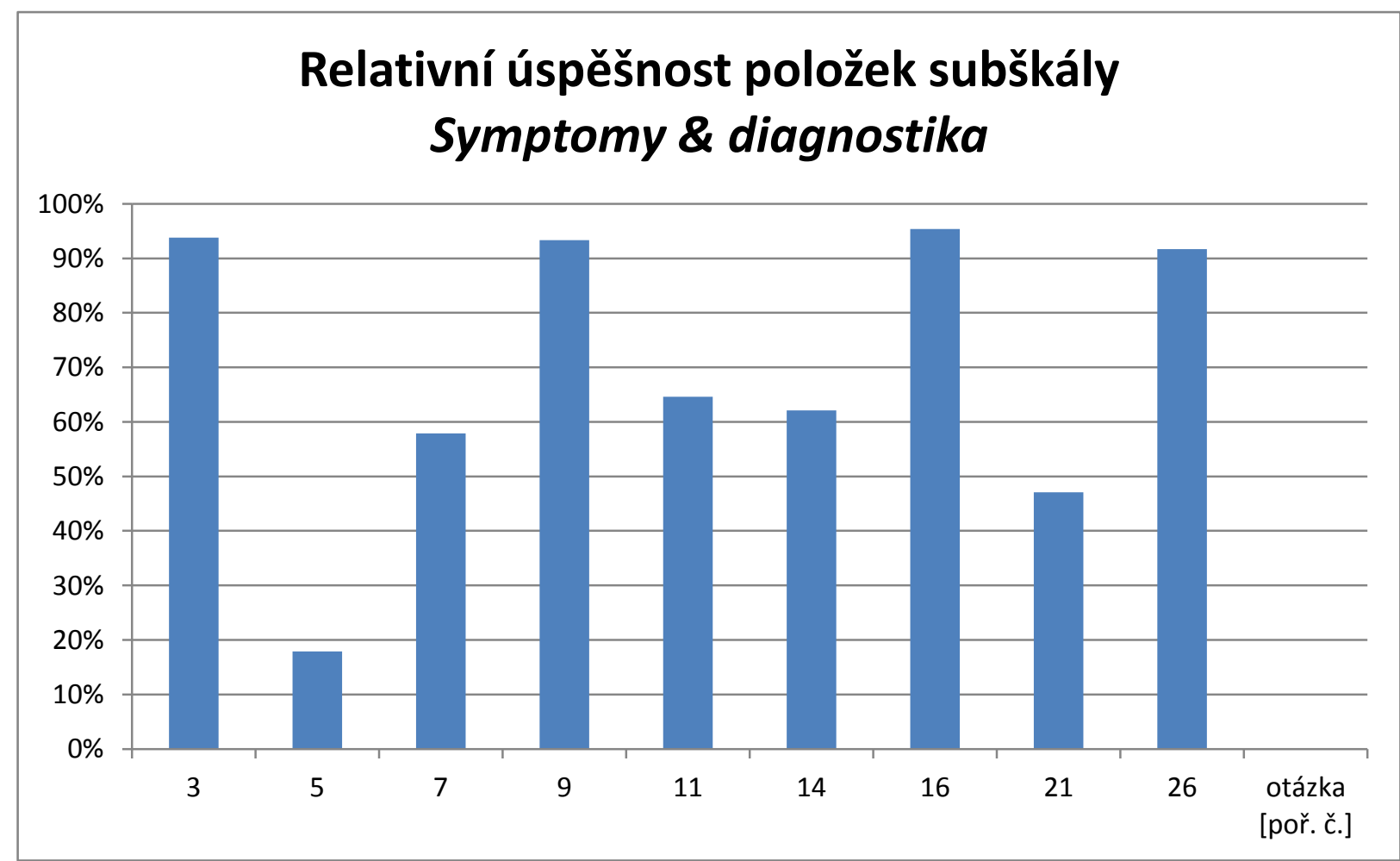

Graf 17: Relativní úspěšnost položek subškály Symptomy \& diagnostika 


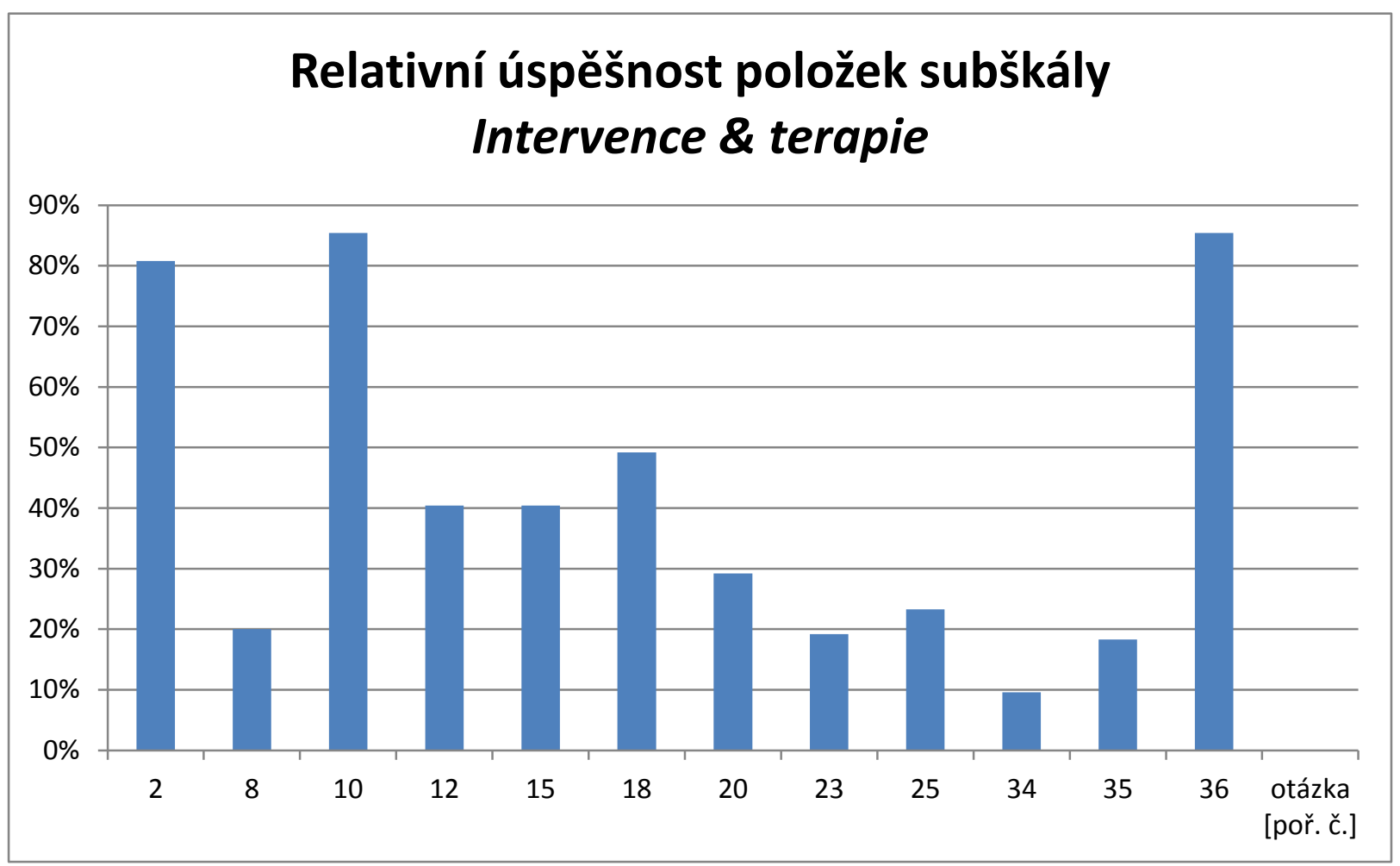

Graf 18: Relativní úspěšnost položek subškály Intervence \& terapie

Ukázalo se, že voblasti všeobecných znalostí (subškála V̌̌eobecně $o A D H D)$ se výrazná většina pedagogů uměla správně rozhodnout u položek:

- Diagnóza ADHD je důvodem k zařazení dítěte do speciální školy (položka č. 24, správná odpověd' = NE， úspěšnost $81 \%$ ). Samotná diagnóza ADHD totiž není indikací $\mathrm{k}$ zařazení do speciální školy, záleží na hloubce poruchy a na přidružených komorbiditách.

- Je-li dítě s ADHD schopno se hodinu a více soustředěně věnovat hraní počítačových her, pak je schopno se stejně dlouho soustředěně věnovat i školní práci a plnění svých úkolů (položka č. 22 , správná odpověd' = NE, úspěšnost $76 \%$ ).

- I děti bez ADHD pocházející z nevhodného rodinného prostředí mohou vykazovat symptomy odpovídající symptomům ADHD (položka č. 33, správná odpověd' = ANO, úspěšnost 76 \%). 
Naopak velká většina pedagogů chybovala při posuzování pravdivosti následujících tvrzení:

- Dítě s ADHD se typicky chová lépe v přítomnosti otce než v př́ítomnosti matky (položka č 4, správná odpověd' = ANO, úspěšnost $9 \%$ ).

- Děti s ADHD mají více problémů v nových než v běžných situacích (položka č. 27, správná odpověd' = NE, úspěšnost $12 \%$ ).

V oblasti diagnostiky (subškála Symptomy \& diagnostika) výrazná většina pedagogů uměla správně posoudit pravdivost tvrzení:

- Hlavní symptomy ADHD jsou porucha pozornosti a impulzivita / hyperaktivita (položka č. 16, správná odpověd' = ANO, úspěšnost $95 \%$ ).

- Děti s ADHD se často nechají rozptylovat vnějšími podněty (položka č. 3, správná odpověd' = ANO, úspěšnost $94 \%$ ).

- Mají-li děti s ADHD sedět, často se vrtí a ošívají (položka č. 9, správná odpověd” = ANO, úspěšnost $93 \%$ ).

- Děti s ADHD mají často potíže s organizací a plněním svých úkolů a povinností (položka č. 26, správná odpověd' = ANO, úspěšnost $92 \%$ ).

Výrazná neznalost pedagogů byla prokázána u položky:

- Diagnózu ADHD je možno přidělit pouze $\mathrm{v}$ případě, že se symptomy poruchy projevovaly již před 7. rokem života dítěte (položka č. 5, správná odpověd' = ANO, úspěšnost $18 \%$ ). Neúspěšnost našich učitelů lze pravděpodobně objasnit direktivitou tvrzení v položce, která zřejmě respondenty mate. Je třeba také zmínit vývoj diagnostických kritérií dle DSM-5, kde je nově stanoveno zjištění výskytu projevů ADHD před 12. rokem života. Pedagogičtí pracovníci bývají na vzdělávacích akcích upozorňováni, že $\mathrm{v}$ souvislosti $\mathrm{s}$ věkem dochází $\mathrm{k}$ změnám obrazu ADHD celoživotně. Dalším aspektem pak je skutečnost, že se pedagogům správně zdůrazňuje, že syndrom ADHD má charakter celoživotního zatížení a nejasnou prenatální, perinatální 
a postnatální etiologii - z tohoto tvrzení lze odvodit, že i v pozdějším věku lze ADHD diagnostikovat (např. mohou být úrazy hlavy a mozku v pozdějším věku). Je třeba také uvést, že podobně neúspěšná byla tato podložka i v jiných výzkumech, nap̌r. Sciutto (2000a), viz tabulka 25.

V oblasti reedukační a terapeutické (subškála Intervence \& terapie) většina pedagogů ví, že:

- jako nejefektivnější se při péči o děti s ADHD jeví kombinace speciálně pedagogického přístupu učitele, poučeného přístupu rodičů a medikace dítěte (položka č. 10, správná odpověd' = ANO, úspěšnost $85 \%$ ),

a také ví, že by bylo chybou zastávat názory:

- Péče o děti s ADHD primárně zaměřená na tresty je při redukci symptomů poruchy nejúčinnější (položka č. 36, správná odpověd' = NE, úspěšnost $85 \%$ ).

- ADHD je často důsledkem nevhodného výchovného působení rodičů (položka č. 2 , správná odpověd' $=\mathrm{NE}$, úspěšnost $81 \%$ ).

Naopak velká většina pedagogů chybovala při posuzování pravdivosti tvrzení:

- Kognitivně-behaviorální/psychologická intervence je u dětí s ADHD primárně zaměřena na redukci symptomů poruchy pozornosti (položka č. 34 , správná odpověd’ = NE, úspěšnost $10 \%$ ).

\subsubsection{Komparace se zahraničními výsledky}

Byla provedena komparace výsledků UJEP 2014 s výsledky jiných autorů. Pro porovnání byly zvoleny veličiny, které se v pracích nejčastěji vyskytují a dostatečně výstižně charakterizují znalosti respondentů o ADHD, tj. relativní KADDS skóry celé škály a jednotlivých subškál (ø [\%]), a dále směrodatné odchylky skórů (SD [\%]), viz tabulka 24 . V některých případech nebyly v primárním zdroji všechny hodnoty uvedeny a v tabulce jsou pak označeny jako neuved. Alkahtani uvádí o znalostech saudskoarabských pedagogů, že nejvyšší $60 \%$ zastoupení četností v KADDS škálách měla odpověd' nevím, což je 
zřejmě příčinou velmi nízkých skórů zjištěných při jeho výzkumu (Alkahtani 2013). Odlišný charakter mají data uváděná o znalostech pedagogů v Thajském království - autoři pro charakterizování úrovně znalostí zvolili relativní počet respondentů, kteří překročili 50\% hranici úspěšnosti v celé škále, resp. v jednotlivých subškálách.

Tabulka 24: Celkový relativní KADDS - mezinárodní srovnání

\begin{tabular}{|c|c|c|c|c|c|c|c|c|c|}
\hline \multirow[b]{3}{*}{ Výzkum } & \multicolumn{9}{|c|}{ Relativní KADDS skór } \\
\hline & \multicolumn{2}{|c|}{ celá škála } & \multicolumn{2}{|c|}{ Všeobecně o ADHD } & \multicolumn{2}{|c|}{ Symptomy \& diagnostika } & \multicolumn{2}{|c|}{ Intervence \& terapie } & \multirow{2}{*}{ abs. $\left[N_{R}\right]$} \\
\hline & $\varnothing[\%]$ & SD [\%] & $\varnothing[\%]$ & SD [\%] & $\varnothing[\%]$ & SD [\%] & $\varnothing[\%]$ & SD [\%] & \\
\hline $\begin{array}{l}\text { Česká republika } \\
\text { - UJEP } 2014\end{array}$ & 51,3 & 12,4 & 48,1 & 15,6 & 69,3 & 17,2 & 41,8 & 16,6 & 240 \\
\hline USA (Sciutto 2000a) & 47,8 & 18,6 & 42,9 & 19,2 & 62,8 & 23,7 & 42,8 & 21,3 & 149 \\
\hline USA (Small 2003) & 57,4 & 15,2 & 50,7 & 18,0 & 71,6 & 16,4 & 55,2 & 18,6 & 72 \\
\hline Austrálie (Kos 2004) & 60,7 & 14,8 & neuved. & neuved. & neuved. & neuved. & neuved. & neuved. & 120 \\
\hline JAR (Kleynhans 2005) & 42,6 & neuved. & neuved. & neuved. & neuved. & neuved. & neuved. & neuved. & 522 \\
\hline $\begin{array}{l}\text { Španělsko } \\
\text { (Jarque Fernández 2007) }\end{array}$ & 42,5 & 18,6 & 31,7 & 18,0 & 63,7 & 24,4 & 40,3 & 22,3 & 193 \\
\hline USA (Graeper 2008) & 53,8 & neuved. & 52,1 & neuved. & 67,7 & neuved. & 45,4 & neuved. & neuved. \\
\hline $\begin{array}{l}\text { Vietnam } \\
\text { (Graeper 2008) }\end{array}$ & 40,4 & neuved. & 35,3 & neuved. & 56,3 & neuved. & 34,9 & neuved. & 46 \\
\hline Kanada (Hepp 2009) & 54,4 & 14,7 & neuved. & neuved. & neuved. & neuved. & neuved. & neuved. & 66 \\
\hline USA (Guerra 2012) & neuved. & neuved. & 46,5 & 17,4 & 66,7 & 17,9 & 56,9 & 17,7 & 107 \\
\hline $\begin{array}{l}\text { Saudskoarabské král. } \\
\text { (Alkahtani 2013) }\end{array}$ & 17,2 & neuved. & 16,8 & neuved. & 18,1 & neuved. & 16,6 & neuved. & 429 \\
\hline \multirow{2}{*}{$\begin{array}{l}\text { Thajské království } \\
\text { (Muanprasart 2014) }\end{array}$} & \multicolumn{8}{|c|}{$\begin{array}{l}\text { Uveden jen relativní počet respondentů, kteří překročili v testu a jeho } \\
\text { částech hranici relativní úspěšnosti } 50 \% \text {. }\end{array}$} & \multirow[t]{2}{*}{201} \\
\hline & 19,4 & neuved. & 12,9 & neuved. & 62,7 & neuved. & 12,4 & neuved. & \\
\hline
\end{tabular}

Z porovnání údajů uvedených v tabulce 24 lze vyvodit následující závěry:

- Průměrný relativní KADDS skór se obvykle pohybuje kolem 50 \% a výsledky dosažené v České republice se výrazně neodlišují o většiny ostatních zemí.

- Průměrný relativní KADDS skór byl ve všech případech zatížen značně velkou chybou (SD > $10 \%$ ). Rozsah publikovaných dat 
nepostačuje ke spolehlivému statistickému posouzení významnosti většiny vzájemných rozdílů KADDS skórů zjištěných při nezávislých šetřeních.

- Teoretické znalosti pedagogů jsou všeobecně nejlepší v oblasti diagnostiky (subškála Symptomy \& diagnostika). Vzájemné rozdíly mezi znalostmi v subškálách Všeobecně o ADHD a Intervence \& terapie jsou výrazně menší a znalosti pedagogů v těchto oblastech jsou přibližně vyrovnané - při jednotlivých šetřeních však mohou být výsledky v jedné z oblastí statisticky významně lepší než v oblasti druhé.

- Většina výzkumů zahrnovala dostatečně velké vzorky respondentů n>100, výzkum UJEP 2014 patří se 240 respondenty k nejrozsáhlejším.

- Metaanalýza výše uvedených výzkumných šetření dále potvrdila předpoklad, že respondenti bez ukončeného vysokoškolského vzdělání (maturita, studenti škol připravujících učitele) mají horší teoretické znalosti o ADHD než učitelé s ukončenou pedagogickou přípravou terciárního stupně.

- V některých zemích (např. Saudskoarabské království) jsou znalosti pedagogů o ADHD výrazně horší než v ostatních zemích.

Dále bylo ve vybraných šetřeních provedeno porovnání položek zařazených do pásem velmi velké a velmi malé úspěšnosti ve výzkumech realizovaných v USA (Small 2003), v Kanadě (Hepp 2009) a v České republice - UJEP 2014, viz tabulka 25. Položky, které měly v jednotlivých výzkumech shodně velmi velkou úspěšnost nebo velmi malou úspěšnost, jsou v tabulce označeny šedým podbarvením a tučným písmem. Jediná položka, která v jednom z výzkumů patřila mezi nejúspěšnější a v jiném mezi nejméně úspěšné, je vyznačena přeškrtnutým písmem. Ukázalo se, že položky č. 3 , 9 a 26 měly shodně ve všech výzkumech velmi velkou úspěšnost. U položek s velmi malou úspěšností je dobrá shoda mezi výzkumem v USA a v České republice (shoda u položek č. 4, 5, 27 a 34), kanadský výzkum se výrazně odlišuje a voblasti položek s velmi malou úspěšností se s ostatními shoduje pouze v položce č. 4 . 
Tabulka 25: Úspěšnost položek škály KADDS - mezinárodní srovnání

\begin{tabular}{|c|c|c|c|c|c|c|}
\hline \multirow{3}{*}{ Úspěšnost } & \multicolumn{6}{|c|}{ Úspěšnost položek škály KADDS } \\
\hline & \multicolumn{2}{|c|}{ USA (Small 2003) } & \multicolumn{2}{|c|}{ Kanada (Hepp 2009) } & \multicolumn{2}{|c|}{ UJEP 2014} \\
\hline & č. pol. & $\eta[\%]$ & č. pol. & $\eta[\%]$ & č. pol. & $\eta[\%]$ \\
\hline \multirow{6}{*}{ Velmi velká } & 9 & 99 & 3 & 91 & 16 & 95 \\
\hline & 3 & 97 & 9 & 94 & 3 & 94 \\
\hline & 13 & 94 & 13 & 94 & 9 & 93 \\
\hline & 26 & 93 & 27 & 92 & 26 & 92 \\
\hline & 10 & 89 & 26 & 88 & 36 & 85 \\
\hline & 16 & 89 & & 0 & 10 & 85 \\
\hline \multirow{5}{*}{ Velmi malá } & 34 & 17 & 12 & 18 & 35 & 18 \\
\hline & 27 & 15 & 36 & 17 & 5 & 18 \\
\hline & 4 & 15 & 2 & 14 & 27 & 12 \\
\hline & 5 & 10 & 22 & 11 & 34 & 10 \\
\hline & 1 & 10 & 4 & 5 & 4 & 9 \\
\hline
\end{tabular}

Ukazuje se tedy, že lze všeobecně předpokládat, že pedagogové budou umět správně posoudit pravdivost následujících tvrzení:

- Položka č. 3: Děti s ADHD se často nechají rozptylovat vnějšími podněty (správná odpověd' = ANO).

- Položka č. 9: Mají-li děti s ADHD sedět, často se vrtí a ošívají (správná odpověd = ANO).

- Položka č. 26: Děti s ADHD mají často potíže s organizací a plněním svých úkoli̊ a povinností (správná odpověd' = ANO).

Velmi malá úspěšnost je např́ič výzkumy u položky č. 4:

- Položka č. 4: Dítě $\mathrm{s} A D H D$ se typicky chová lépe $\mathrm{v}$ přítomnosti otce než v přítomnosti matky (správná odpověd' = ANO).

Pedagogové budou s vysokou pravděpodobností chybovat u tvrzení:

- Položka č. 5: Diagnózu ADHD je možno přidělit pouze v případě, že se symptomy poruchy projevovaly již před 7 . rokem života dítěte (správná odpověd' = ANO).

- Položka č. 27: Děti s ADHD mají více problémů v nových než v běžných situacích (správná odpověd' = NE).

- Položka č. 34: Kognitivně-behaviorální/psychologická intervence je u dětí s ADHD primárně zaměřena na redukci symptomů poruchy pozornosti (správná odpověd' $=\mathrm{NE}$ ). 


\section{Př́iklady dobré a špatné praxe}

„Největši zázrak sněhových vloček je v jejich jedinečnosti. Každá je jiná, neopakovatelná. Stejně jako lidé."

Mnoho lidí vnímá obsah obou termínů integrace a inkluze stejně, a to včetně učitelů, což není správné. Proto považujeme za nebytné uvést také příklady dobré a špatné praxe při inkluzi/integraci žáků s ADHD do běžného vzdělávacího proudu tak, aby si čtenáři mohli na konkrétních příkladech uvědomit rozdíly a promyslet edukační strategie pro vlastní pedagogickou praxi.

Při integraci pomáháme dítěti se začleněním do třídy mezi intaktní populaci, uzpůsobíme podmínky tak, aby se žák mohl dobře přizpůsobit životu třídního kolektivu. Inkluzivní přístup vychází z názoru, že dítě má právo navštěvovat běžnou základní školu, a to nejlépe od první tř́idy v místě bydliště. Respektuje, že každý člověk, a děti s postižením nevyjímaje, je osobnost s určitými schopnostmi, dovednostmi a osobnostními rysy. Naším cílem by tedy mělo být, že mu poskytneme takové prostředí, ve kterém najde optimální podněty pro svůj rozvoj bez ohledu na postižení, které má a které není překážkou společnému vzdělávání. Inkluze tedy znamená vytvoření diferencovaných podmínek různým dětem tak, že budou v prostředí, které je optimálně rozvíjí, a přitom mohou pracovat společně, ve výkonově heterogenní skupině. Smyslem inkluzivní školy by tedy mělo bezesporu být i odstraňování zažitých sociálních bariér.

Přesto, že hovoříme o existenci inkluze v české škole, musíme si přiznat, že jsme stále spíše v rovině integrace. Zatím u nás stále existují pro rodiče dětí s postižením dvě možnosti, jak jejich děti mohou potřebné vzdělání získat. Bud’ formou individuální či skupinové integrace $\mathrm{v}$ běžném vzdělávacím proudu spolu s intaktní populací nebo formou segregativní v prostředí speciální školy. Problémy, které 
mohou nastat vintegrovaném vzdělávání na škole běžného typu, mohou v dospělém každodenním životě přinést užitek. Žák se učí žít $\mathrm{v}$ přirozeném společenském prostředí se všemi jeho pozitivy i negativy. Velkou roli při úspěšné integraci sehrávají osobní vlastnosti jedince, hloubka jeho postižení, kvalita rodinné péče, př́istup a podmínky školy, ochotní, vzdělaní a myšlenkám integrace vstřícní učitelé. Z toho je zřejmé, že obojí řešení, tedy zařazení nebo nezařazení mezi intaktní vrstevníky na základní školu, má své klady i zápory.

Z následujících několika příkladů dobré a špatné praxe v českých školách a názorů učitelů na integraci/inkluzi vyplývá, že jsou spíše této formě vzdělávání pozitivně nakloněni, ovšem nezavrhují ani vzdělávání v systému škol speciálních. Při práci s integrovanými žáky s ADHD, s poruchou chování, ale logicky i s jakýmkoliv jiným postižením jsou standardní nároky na práci učitelů automaticky navýšeny nad běžný rámec povinností. Pedagog v práci s takovými žáky musí být velmi znalý psychických zvláštností dětí a musí umět jasně stanovit mantinely vedoucí k posílení kázně. Je nezbytné, aby znal prostředky umožňující aplikaci zdravé důslednosti v přístupu k dětem ve třídě. Zároveň je z jeho strany nezbytné uplatňovat $\mathrm{v}$ zásadě klidný a důsledný výchovný přístup, umět poskytnout citovou oporu ve chvílích potřeby žáka, být ochotný mu pomoci i nad rámec svých pracovních povinností, být chápavý, empatický a podporovat žákovu sebedůvěru, ale i být na výši po stránce didaktické a metodické ve svém oboru. A to vše stojí osobní energii a čas. Tím však není řečeno, že by tomu tak v podmínkách soudobého školství nemělo být. Při práci s dětmi s poruchou chování však bývá velkou výhodou, jak z následujících příkladů vyplývá, možnost působení školního psychologa, etopeda, asistenta pedagoga přímo ve škole. To však přináší zvýšené ekonomické nároky na provoz školy. Nezanedbatelná je i občasná možnost vzdělávat takového žáka mimo kmenovou třídu, poskytnout mu prostor, kdy bude mít klid od ostatních, kde se může i zregenerovat z únavy dostavující se při neustálém tlaku na jeho 
výkon. Samotná integrace ovlivňuje nejen samotné integrované žáky, ale také ostatní žáky třídy, pomáhá odstraňovat předsudky a utváří u žáků empatičtější vztah k okolí, který si odnesou až do období dospělosti. Integrace, jsou-li splněny požadované podmínky, má svůj smysl a její existenci ve školách lze považovat za velmi přínosnou.

\subsection{Př́iklady dobré praxe}

\subsubsection{Dobrá praxe - příklad první}

Je i zajímavé, jak rozdílná práce s žáky s ADHD při jejich integraci může být. V červnu nám odešel z devátého ročníku žák Lukáš, u kterého byla diagnostikována dyslexie, dysortografie, grafomotorické potíže související s primárním postižením (DMO - pravostranná spastická hemiparéza) v kombinaci s ADHD typu s narušenou pozorností.

Lukáš k nám na ZŠ přišel na druhý stupeň, první stupeň prožil na malé, téměř rodinné škole, která druhý stupeň nemá. Ještě než k nám nastoupil, proběhlo několik setkání s rodiči, kteří měli velkou obavu o syna. Byli frustrovaní z toho, zda tuto velkou změnu zvládne, jestli nenastane problém s výukou, najde-li si kamarády, nebudou-li se mu ostatní spolužáci kvůli jeho handicapu posmívat. Musím říct, že Lukášův vstup do naší školy proběhl téměř bez problémů. Ostatní spolužáci ho ihned vzali mezi sebe, nedělali žádné rozdíly mezi ním a ostatními žáky. I vyučující se snažili chlapci co nejvíce pomáhat, řídit se radami, které doporučovala poradna a námi vypracovaný individuální vzdělávací plán (dále jen IVP) - především mu poskytovali prezentace $\mathrm{z}$ výuky $\mathrm{k}$ vytištění, protože byl velmi pomalý a na zápisy do sešitu se nebyl schopen soustředit. Ty si mohl zakládat do kroužkového bloku, takže měl u sebe neustále přehled učiva. Protože měl problémy s angličtinou, nemusel přibírat v sedmé třídě druhý cizí jazyk, což je u nás francouzština - a místo toho měl rozšířenou výuku angličtiny.

Lukášovi vzhledem $\mathrm{k}$ jeho tělesnému postižení byla přidělena i asistentka pedagoga, což někteří pedagogové velmi těžce nesli. 
S Lukášem však z mého pohledu pracovala velmi dobře. Snažila se být neustále v kontaktu s jeho rodiči. Pokud se jim cokoliv nezdálo nebo potřebovali nějakou radu, tak to s vyučujícím příslušného předmětu hned konzultovala. Společně se snažili najít pomoc, probrat danou situaci a nějak ji vyřešit. Když bylo třeba, brala si Lukáše do kabinetu, kde s ním probírala učivo, které chlapec nezvládal, ale kde ho nechávala i obyčejně odpočinout, když byl již zcela vyčerpaný z běžných hodin. Nikdy za něj nepracovala, jen mu skutečně pomáhala.

Co se mi velmi líbilo, byl vztah ostatních spolužáků k Lukášovi. Myslím si, že se zde projevila velmi dobrá práce paní třídní učitelky se žáky. Aniž by kdokoliv něco řekl, snažili se chlapci pomáhat, nosit věci, pokud jich přenášel do jiných učeben víc, zvednout židli, když bylo potřeba, vzít tašku, ale neměla jsem pocit, že by mu sloužili. Rozhodně prrítomnost Lukáše přispěla $\mathrm{k}$ socializaci celé třídy.

Vypadá to, že vše bylo ideální a nedošlo k žádným problémům, což samozřejmě není pravda. I tady občas něco zaskřípalo, ale nedělo se nic zásadního. Lukáš zvládl čtyři roky bez potíží, většina učitelů si nakonec na téměř stálou přítomnost asistentky zvykla, rodiče byli spokojeni. Myslím si, že v tomto případě se integrace žáka podařila. Skvělá byla spolupráce rodičů, kteří se dle mého názoru s handicapem syna smírili, vyučujících, osobní asistentky a pokud bylo potřeba, tak i pracovníků pedagogicko-psychologické poradny. Lukáš byl i v některých předmětech velmi úspěšný, samozřejmě s malou pomocí, což bylo vidět i na jeho sebevědomí. Na vysvědčení měl uvedeno, že pracoval podle IVP.

\subsubsection{Dobrá praxe - př́íklad druhý}

Když jsem na tuto školu přišla, tak už byl žák v sedmé třídě. Takže předchozí trable znám pouze $\mathrm{z}$ vyprávění. Byl to chlapec $\mathrm{z}$ města, který první dva roky absolvoval na škole ve městě. Tam zřejmě poznali, že mezi třiceti žáky by se mu nemohli plně věnovat, a tak usoudili, že pro něho bude lepší venkovská škola. Nejsem si ale jistá, 
od koho ten impulz vzešel. Nastoupila jsem na školu jako zástup za mateřskou dovolenou. Předešlá paní učitelka mě se vším obeznámila, právě i s tímto žákem. Ale jak jsem již říkala, dokud člověk není do té vody hozen, tak to nepochopí.

Učitelky, které ho měly na prvním stupni, mi s nadsázkou říkaly, že to bylo takové malé zvírátko. Kdyby si jakýkoliv člověk prohlédl fotky třídy, tak hned na první pohled pozná, který žák je tam integrovaný... Bylo to poznat z výrazu tváře. Byl evidován v SPC a spolupracovali se speciálním pedagogem. Mne se jeho integrace týkala dost podstatnou měrou $\mathrm{z}$ toho důvodu, že jsem ho učila matematiku. Bohužel neměl asistenta pedagoga. Můj názor je, že by mu značnou měrou pomohl. Ovšem po dohodě s rodiči se mu po vyučování věnovala vychovatelka, která s ním právě matematiku a český jazyk procvičovala a dělala domácí úkoly.

Protože jsem byla teprve první rok ve školství, tak to pro mě bylo docela náročné. Byl hodný, nevyrušoval, ale ztrácel pozornost, a proto jsem ho pořád musela sledovat, jestli je na správné stránce v učebnici, připomínat mu, že si má psát. Vyvolávat ho, aby se necítil odsunutý a zároveň ho vyvolat na takové věci, o kterých jsem věděla, že je umí. Učitelky na prvním stupni jsou na to asi zvyklé, že děti neustále kontrolují. I to jestli si umyly ruce a podobné maličkosti. Ale my na druhém stupni? Zde to není tak obvyklé. Ale u něho musel mít člověk pořád v hlavě to, že nesmím zapomenout ho zkontrolovat. Na druhou stranu, když jsem to s tou péčí přeháněla, tak už mu to nebylo př́ijemné, odsouval mi ruku a dával mi najevo, at̉ už jdu pryč. Ted' přichází v jeho př́ípadě podstatná otázka. Co na to kolektiv? Jak ho přijmou? Bude to pro něho přínosné?

Musím říci, že měl obrovské štěstí na žáky kolem sebe. Nejen na třídu, ale dokonce na celou školu. V osmé třídě jsem je dokonce dostala za třídní, takže jsem ho měla možnost poznat ještě blíže. Měla jsem tu výhodu, že učitelky přede mnou udělaly ohromný kus práce a v této fázi ten rozdíl mezi ním a ostatním žactvem ve třídě už nebyl tak markantní. Ale vratme se k otázce kolektivu. $\mathrm{S}$ touto třídou měla 
spousta kantorů problémy. Z hlediska prospěchu na tom nebyli moc dobře, chování o hodinách vyučovacímu procesu taky nepomáhalo. Takže většina učitelů se musela zaměřovat na usměrňování žáků a tudíž bylo o to těžší se věnovat integrovanému žákovi. Ale jak jsem řekla, tak ostatní spolužáci ho brali mezi sebe. Nikdy by na něho nepořvávali něco nevhodného, neshodili by ho před ostatními. Ba naopak. Klidně se ho zastali, pomohli mu. Musím říci, že nám do značné míry pomohl žák s výborným prospěchem, který seděl vedle něho, a když bylo potřeba, tak mu klidně stránku v učebnici otočil. No není to štěstí? Při tom všem, čím si prošel, tak se mu alespoň v tomto případě štěstí naklonilo.

Se třídou jsme narazili na jediný problém. Pokud jsme chtěli něco vyřešit pouze v našem kruhu a nepotřebovali jsme, aby se to vyneslo do celé školy, tak u toho nemohl být onen žák. Měl tu potřebu, že cokoliv se zajímavého dozvěděl, tak roznesl dál. Ale to byl téměř nepodstatný problém, který se dal nějak řešit. Z mého pohledu tedy kolektiv měl obrovskou zásluhu na tom, jak se pozitivně vyvíjel. Ale jak už literatura píše, neměl jen kolektiv vliv na něho, ale i on měl vliv na tu neposednou třídu. Všichni se mírnili ve vyjadřování, pokud šlo o daného žáka. A do budoucna je už někdo takový nepřekvapí, naučili se, jak se k takovým žákům chovat. Uznejte, že v tomto konkrétním případě byla integrace vhodná.

\subsubsection{Dobrá praxe - př́íklad třetí}

Standa (jméno je smyšlené) je momentálně žákem 4. třídy základní školy. Má diagnostikovaný syndrom ADHD, je v péči dětské psychiatrie, medikován Ritalinem. Aktuální rozumové schopnosti se u něj nacházejí v pásmu vysokého nadprůměru, s převahou velmi vysokých verbálních dispozic. Vedle nadprůměrné kognitivní úrovně je přítomna socio-emoční labilita a nezralost. V psané podobě se u něj objevují náznaky lehké dysgrafie a dysortografie.

V minulosti prakticky nebylo pedagogické rady, kdy by nebylo slyšet: „Standa mě zase vytočil, ten mně opravdu zpestřuje hodiny, jsem rád 
za každý den, kdy není ve škole...“ aj. Problém byl v tom, že na sebe velmi rád upozorňoval v hodinách různými výkřiky či povykováním na spolužáky, častým a opakovaným nenošením školních pomůcek. Situace gradovala ve třetí třídě, kdy i přes individuální postupy a pomoc učitelek selhával. Výsledkem byl neprospěch ve třech vyučovacích předmětech (čeština, angličtina, matematika) a opakování třetí třídy. A tady došlo k velké změně. V pưvodní třídě byl ostatními dětmi považován za „exota“, stejně tak zřejmě i paní učitelkou. Jeho rušivé projevy ve výuce mnohým spolužákům vadily. S těmi se pak dostával do ostrých konfliktů. Opravdových kamarádů měl velmi málo, spíše jen jednoho. V nové třídě ze strany třídní učitelky panovala obava, co všechno chlapcův příchod způsobí, ale třída jej přijala velmi dobře a Standa zde navázal pěkné sociální kontakty. Okruh jeho kamarádů se rozšírill. Děti jej vnímají jako každého jiného v tomto kolektivu.

Současná paní učitelka pravidelně spolupracuje v otázkách podpory Standy se speciálně-pedagogickým centrem, pravidelně s etopedem.

Standa je v současné době integrován na základě platného posudku SPC a je pro něj vypracován IVP, v němž jsou hlavně zakomponována tato opatření:

- tolerance pomalého tempa,

- akceptace kolísání pozornosti,

- psaní prověrek v časové prolongaci, popřípadě jejich zkrácené či upravené varianty, s nehodnocením specifických chyb,

- preference ústního projevu.

Ve vyučovacích hodinách se mu dostává přiměřené, nikoliv nadměrné pozornosti, pokud je někdy př́liš unavený, může si jít odpočinout na žíněnku v koutě třídy, kde jsou i různé válecí polštáře. Těch rád využívá, dává si je na hlavu, naznačuje tak, že nic v tu chvíli nechce vidět, slyšet, potřebuje prostor pro sebe. V hodinách tělesné výchovy, výtvarné výchovy a pracovního vyučování jsou plně akceptovány jeho dispozice - je nešikovný, neobratný, nikdo mu však specifickou 
poruchu motorických dovedností nikdy nediagnostikoval, což nás ve škole udivuje.

Práce s takovým žákem, jakým je Standa, v podmínkách běžné základní školy rozhodně jednoduchá není, ale to v podstatě není jednoduchá i v případě kteréhokoliv ze žáků, jež mají nějaký výchovný, sociální či specifický problém

\subsubsection{Dobrá praxe - př́iklad čtvrtý}

Jára byl od 4 let $\mathrm{v}$ běžné mateřské škole, jeho adaptace na denní režim v mateřské škole byla velmi bouřlivá. Projevoval se u něj výrazný psychomotorický neklid, nepozornost, velmi malá koncentrace pozornosti, byl těkavý a ve společnosti dětí výbušný. Při hrách a činnostech v mateřské škole často provokoval ostatní děti, byl velmi nemotorný.

Navrhli jsme rodičům, aby chlapce nechali vyšetřit v pedagogicko-psychologické poradně (dále jen PPP), kde mu diagnostikovali ADHD $\mathrm{s}$ dyspraxií. V současné době je Jára integrovaný na základě posudku PPP a je pro něj vypracován IVP s následujícími doporučeními:

- tolerovat zvýšenou aktivitu chlapce,

- stanovit jasná pravidla chování a dodržovat pravidelný denní režim, jak v mateřské škole, tak v rodině,

- pozitivně chlapce motivovat a pochválit jej za dobrý výkon, ale i za dílčí zlepšení nebo projevenou snahu,

- při zbrklém jednání vést chlapce ke klidu a rozvaze a zpětné kontrole jeho jednání a později jej odměnit za snahu při dalších aktivitách,

- trénovat pravidelně rozvoj jemné a hrubé motoriky,

- posilovat koncentraci pozornosti.

Učitelky mateřské školy a rodiče se snaží dodržovat doporučení PPP navržená v rámci IVP a chlapec se zlepšuje voblasti komunikace s ostatními dětmi a lépe se mu daří zapojit do dětského kolektivu i přes jeho psychomotorický neklid a nemotorné projevy. 


\subsection{Příklady špatné praxe}

\subsection{1 Špatná praxe - příklad první}

Ve školství pracuji již od roku 1987. Nyní pracuji v dětském domově. Zastávám názor, že integrace/inkluze jsou v současné době pojmy často používané a módní, mnohdy ne zcela správně a opodstatněně. Integrace/inkluze by neměly být vnímány jako módní trendy doby, měly by se stát životním postojem každého $\mathrm{z}$ nás. K takovému vnímání je však třeba postupně dospět. Soužitím a společnou výchovou dětí intaktních s dětmi s postižením již od raného dětství, plynule a zcela přirozeně pak pokračovat společným vzděláváním na základní škole. Otázkou však zůstává, nakolik jsou na integraci/inkluzi připraveny právě základní školy. Nejedná se totiž jen o materiální vybavení, ale i o celkovou politiku a přístup škol, o podporu. Chtěla bych se podělit o prríklad integrace jedné naší uživatelky z dětského domova, která chodí do 4. třídy základní školy, má tzv. hraniční schopnosti, které variují od průměru po lehkou mentální retardaci a tudíž nepatří svým zařazením zcela logicky nikam jinam, než do základní školy.

\section{Rodinná anamnéza děvčete}

Dívka XY pochází ze třech sourozenců. Starší sestra byla matce odebrána před čtyřmi lety a umístěna do dětského domova (dále jen DD). Dívka, na níž chci dokumentovat príklad praktického průběhu integrace, byla matce odebrána a umístěna do DD před třemi lety, kdy byl její partner (otec nejmladšího syna) obviněn ze sexuálního obtěžování XY. Vlastní otec obou dívek se s rodinou nestýká.

\section{Osobní anamnéza}

$\mathrm{XY}$ se narodila ve 32. týdnu těhotenství jako nedonošené dítě, v jeho průběhu došlo $\mathrm{k}$ porodnímu hypotonu a následné asfyxii. Při narození vážila $2.150 \mathrm{~g}$ a měřila $42 \mathrm{~cm}$. Byla umístěna v inkubátoru. Po návratu domů byla krmena umělou stravou, nikdy nebyla kojena. Psycho- 
motorický vývoj byl celkově opožděný, chodit bez opory začala až ve 20 měsících, bez problémů udržovat čistotu se naučila až v 5 letech.

\section{Scholarita}

Dívka mateřskou školu ani přípravnou třídu nenavštěvovala. Protože nebyla dostatečně připravena na školní docházku, byl jí doporučen odklad a pokračování v docházce do MŠ. Tam ji však matka vodila pouze občas, podle toho, jak byla schopna ráno vstát, pravidelné docházce nepřikládala velký význam.

Do základní školy do první třídy XY nastoupila v sedmi letech a deseti měsících. Od začátku školní docházky měla výukové i výchovné problémy. Do školy chodila (a chodí) nerada a do školy se netěší. Na žádost vedení školy byla vyšetřena v pedagogicko-psychologické poradně. Projevovala se jako neklidná holčička, nesoustředěná, bez zájmu o úkol. Těžce nesla napomínání, rozzlobila se a odmítla pracovat. Po uklidnění začala komunikovat. Samostatně nebyla schopna pracovat, byla nutná dopomoc a neustálý dohled.

Bylo zjištěno, že se jedná o dívku se slabě průměrnými rozumovými předpoklady pro zvládání učiva, dále s výraznější formou ADHD v kombinaci se středně těžkou dysgrafií a dysortografií a sníženou čtenářskou výkonností. Psycholožka poradny doporučila v rámci školy její zařazení do kategorie žák se speciálními vzdělávacími potřebami a uvedla, že rozsah a závažnost dívčiných obtíží odpovídá zařazení do režimu speciálního vzdělávání formou individuální integrace. Zabezpečení speciální péče v běžné základní škole dle jejího názoru má probíhat prostřednictvím individuálního přístupu k žákyni ve třídě, jejím zařazením do dyslektického kroužku, výukou dle individuálně vzdělávacích plánů - zejména v jazykových předmětech.

\section{Současná situace dívky ve 3. tř́idě - stav jejích vědomostí}

- V českém jazyce má problémy v psaní, nedodržuje linii, písmo je rozličně velké, linie neurovnané a roztřesené. Pracuje v pomalém pracovním tempu, zvládá opis písmen, slov a krátkých vět. 
Diktáty slov zvládá, ale bez diakritických znamének. Ve větách píše slova dohromady, na začátku věty píše malé písmeno. Ve čtení čte plynule slova i věty. Čtenému textu částečně rozumí, o přečteném vypráví za pomoci učitele. Má malou slovní zásobu. Zapamatuje si krátké ř́ḱkanky a básničky. Na stránce i v textu se orientuje dobře.

- V matematice umí samostatně porovnávat čísla, sčítat a odčítat do 20. Ve sčítání a odčítání s přechodem do 100 již chybuje, potíže jí činí rozklad čísel. Slovní úlohy vypočítá s dopomocí, není schopna z textu úlohy pochopit podstatné informace a způsob jejího řešení. Malou násobilku do pěti zvládá s menšími chybami, často si plete operační znaménko násobení se znaménkem na sčítání. Násobky 6 až 10 zvládá jen s dopomocí. V geometrii narýsuje bod, přímku, úsečku a rozlišuje geometrické tvary.

- V přírodovědě a vlastivědě pracovní listy vyplňuje s pomocí pedagoga či spolužáků. Rozlišuje živou a neživou přírodu, ráda vypráví o zvíratech, o lese. Vyjmenuje dny vtýdnu, měsíce a roční období. Zná svou adresu, nepamatuje si datum narození.

\section{Hodnocení individuální integrace a prognóza (z pozice zákonného zástupce)}

Dívka by měla pracovat podle individuálního vzdělávacího plánu, který je vypracován ve spolupráci s poradnou, výchovným poradcem základní školy, dětským domovem a třídním učitelem. Spíše se jedná o formální dokument. Bohužel XY je v kolektivu 28 dětí ve třídě ještě s jedním problémovým chlapcem posazena do poslední lavice a práci v hodině nestíhá, pak ji musí dokončovat v domově. Samozřejmostí by mělo být používání různých gramatických přehledů a tabulek, a to při ústní i písemné práci, ty však ve škole nemá $\mathrm{k}$ dispozici. Na diktáty by se měla dopředu připravit, část diktátu psát, část pouze doplňovat. Nikdy však nemáme od třídní učitelky žádné informace, kdy se diktát bude psát a jaký. Při výkladu nového učiva by bylo důležité ponechat 
dostatek času na procvičování, stavět na bezpečně zvládnutých základech a systematicky opakovat učivo. Nic takového se neděje.

V oblasti chování je XY často roztržitá, nevnímá zadané úkoly, stále vyžaduje pozornost pedagoga. Není schopna pracovat samostatně, nutně potřebuje dopomoc. Často reaguje odmítavě se slovy - neumím, nechci, nerozumím, je mi to jedno. Vzhledem k rychlé unavitelnosti a horšímu soustředění je nutné u ní střídat činnosti a zařazovat častěji přestávky. To se však téměř nedodržuje, takže dívka je nesoustředěná o to více, roztěkaná, často vyrušuje, školní povinnosti si plní jen částečně. Několikrát jí byla udělena důtka třídního učitele za neplnění školních povinností, nikdo však nekontroluje, zda má zapsaný úkol, nikdo jí to nepřipomene. O přestávkách je velmi živá, často hlučná, předvádí se a ubližuje spolužákům. Ve třídě neprobíhá žádný program k podpoře třídních vztahů. Do kolektivu třídy nezapadla, se spolužáky se mimo školu nestýká.

\subsection{2 Špatná praxe - příklad druhý}

Pracuji jako výchovná poradkyně. Chci se zmínit o žákyni Ivance (jméno je samozřejmě smyšlené). Byla zaintegrována do naší školy s diagnózou porucha pozornosti v kombinaci s hraničním intelektem. Její rodiče byli velmi starostliví, o vše se zajímali, setkávali se s paní učitelkou třídní a probírali vše potřebné. Ivaně, která nebyla schopna bohužel pracovat $\mathrm{v}$ hodinách samostatně, byla přidělena asistentka pedagoga, která se velmi snažila a byla neustále v kontaktu s rodiči.

Ale ač se všichni snažili, u Ivanky nebyly patrné žádné úspěchy. Její handicap byl takový, že integrace do „normální“ třídy základní školy dle mého nebyla vhodná. Ivana ani s veškerou pomocí nebyla schopná osvojit si učivo základní školy (samozřejmě tím myslím, že i když se učila podle individuálního vzdělávacího plánu, ve kterém byl snížen objem učiva).

Po čase se začala paní učitelka třídní s mojí pomocí snažit přeřadit Ivču do základní školy praktické. Rodičům se to nejdříve nelíbilo, 
protože tato škola je v podvědomí většiny obyvatel našeho města označována jako „cikánská“. Ale po osobní návštěvě v ní a komunikaci s paní ředitelkou zjistili, že ne všichni žáci jsou Romové, dokonce ve třídě, kam by měla být Ivana zařazena, nejsou. Už to vypadalo, že dívka do této školy nastoupí a konečně zažije úspěch. Ale bohužel se tak nestalo. Jak jsem se již zmínila, spolupráce mezi naší základní školou a místní pedagogicko-psychologickou poradnou je velmi dobrá, ale pouze tehdy, pokud nechceme přeřadit žáka do základní školy praktické. Možná se snaží, aby tento typ škol byl zrušen?

Často se o tom mluví, ale nedokážu si představit, že by všichni žáci byli zařazeni do „normálních“ tříd základních škol. Musím říct, že jsem zažila několik případů, kdy odchod žáka na praktickou školu byl pozitivem pro více stran. Žák v nové škole byl konečně úspěšný, třída si „oddechla“, občas se stávalo, že tito žáci byli velmi hrubí, zlí, nebo si ani neuvědomovali, že mohou svým chováním ublížit, a oddechla si i paní učitelka, která musela neustále řešit spoustu problémů se žáky, které byly velmi často reakcí na chování daného žáka. Čím déle zůstávali tito žáci v ročnících ZŠs, tím víc byly vidět obrovské nedostatky základních znalostí. Spolužáci si jich nevšímali a oni se snažili na sebe upozornit jakýmikoliv zpo̊sobem, tedy i odmlouváním, hrubým chováním, zesměšňováním, vulgárními výrazy...

Ale zpátky k Ivaně; na doporučení pracovníků PPP si rodiče přestup rozmysleli, a tak dívka zůstává na naší škole a přes veškerou snahu pracovníků školy, ale i rodičů, se její pobyt na této škole zhoršuje. Čím dál častěji dochází k tomu, že se jí děti posmívají, nechtějí ji v kolektivu, protože jim nestačí při práci, a není schopná úkoly s nimi řešit. Mám pocit, že se Ivča může cítit „odstrčená“ od ostatních.

Integrace je určitě prospěšná věc, ale pro některé děti může být mnohem lepší prostředí se žáky, kteří mají také nějaký handicap, než ve třídě s intaktními dětmi. Ve speciální třídě se může dítě cítit lépe, poněvadž pocituje, že se neodlišuje od ostatních a všechny děti jsou si zde rovny. Věřím, že situace Ivči se změní a že se podaří její přeřazení 
do základní školy praktické, což si myslím, že je to nejlepší řešení, i když vím, že se mohu mýlit.

\subsection{3 Špatná praxe - příklad třetí}

Pracuji ve speciální mateřské škole jako kvalifikovaná učitelka a momentálně máme integrovaného 5letého chlapce Adama s těžší formou $\mathrm{ADHD}$ za podpory asistenta pedagoga. Adam je těžce výchovně zvladatelný, hyperaktivní, agresivní vůči dětem, svým sourozencům i učitelkám. Bohužel asistent pedagoga je často nemocný a tak jsme rodičům navrhli, at po dobu nemoci asistenta pedagoga si ponechají dítě doma, protože se obtížně hledá náhrada, za asistenta. Rodiče nás nařkli, že je jejich chlapec diskriminován, že nemůže být v sociálním kontaktu s ostatními dětmi, ale zatím jsme nenašli jiné řešení. Občas se sice ptáme rodičů, především maminek, zda by některá nechtěla pomoci s dítětem, ale většinou je ze strany matek malý zájem. Pokud se výjimečně nějaká maminka nabídne, sepisujeme s ní čestné prohlášení, že přebírá zodpovědnost za svěřené dítě. Spolupráce s rodiči je problematická, nebot žijí na ubytovně s dalšími dvěma sourozenci Adama a jejich finanční situace je nepříznivá.

\subsection{4 Špatná praxe - příklad čtvrtý}

Již 25 let pracuji jako učitelka na 1. stupni ZŠ. Vždy jsem se snažila vyjít vstříc všem dětem a jejich rodičům. Nikdy jsem neměla problém začlenit do kolektivu dítě s integrací. Mí nadřízení byli vždy s mou prací spokojeni a nyní, v rámci inkluzivních trendů, mi předělili do třídy dívku s integrací a navíc s podporou asistenta pedagoga. Dívku bych bez problémů jistě zvládla sama. Nejsem však schopná se smírìt s tím, že mám na hodinách neustále asistenta pedagoga, který mě od mé výuky rozptyluje, nejsem schopná se soustředit na děti. Asistent pedagoga je pro mě silný rušivý element a žádala jsme vedení, že ho opravdu nepotřebuji, že si vystačím sama, ale prý ho v rámci integrace doporučila poradna, a proto ho musím ve třídě mít. Je to pro mě přítěž a práce navíc, nejsem zvyklá, aby mi někdo chodil po třídě, já 
musela kontrolovat jeho práci a vést ho v hodině, mám pak méně času na ostatní děti. Navíc jsou ted’ děti v hodinách při práci s asistentem pedagoga méně ukázněné, protože na hodinách nyní sledují dvě osoby, po třídě je větší pohyb a hluk. Z celé situace jsem neštastná a bezradná, doufám, že nastalou změnu budu mít pouze v 2 . třídě a že příští rok již asistenta pedagoga v mé třídě mít nebudu.

\subsection{Názory učitelů na pedagogickou integraci}

Pedagogická integrace byla poprvé v ČR legislativně ošetřena zákonem ČNR č. 390/1991 Sb., o předškolních a školských zařízeních. Píšeme rok 2015, je to tedy již 14 let, kdy jsme začali integraci a následně inkluzi považovat za nové trendy ve vzdělávání. Pročtěme si po tak dlouhé době, jaké jsou názory učitelů na integrativněinkluzivní vzdělávání. Jedná se o názory plně kvalifikovaných učitelů z praxe, kteří si zvyšují svou kvalifikaci v rámci celoživotního vzdělávání. Byla jim slíbena anonymita výpovědi.

1. Jsem velmi ráda, když se integrace podaří, stejně jako u jednoho našeho žáka. Ale zažila jsem již několik případů, kdy se nám to nepodařilo. Většinou se jednalo o žáky s nějakou poruchou chování či s mentálním postižením. Samozřejmě, nevylučuji, že to mohlo být i naší vinou - myslím tím nás, učitele. Pedagogové v základních školách nemají odborné znalosti, aby mohli těmto žákům co nejlépe pomoci. Ale věřím, že většina kolegů pracuje tak, aby měli čisté svědomí. Skvělé by bylo, pokud bychom u nás mohli mít neustále $\mathrm{k}$ dispozici školního psychologa a speciálního pedagoga a problémy se řešily ihned. Peníze ale hrají podstatnou roli. Skvělé je, že školní psycholog k nám dochází alespoň jednou za čtrnáct dní, maximálně však na tři hodiny, a to až po vyučování. Nejčastěji řeší konflikty žáků a jejich rodičů. Ti jsou vždy objednáni na určitou hodinu. Mnohem lepší by bylo, aby školní psycholog mohl být ve škole $\mathrm{v}$ době výuky a mohl zareagovat na konkrétní problém např. konflikt mezi žáky, nebo mezi 
žákem a učitelem. Takových konfliktů bohužel přibývá. Učitelé nemají žádné pravomoci v souvislosti s udržením kázně a doba je opravdu jiná než před $\mathrm{x}$ lety...

2. Osobně nemám mnoho zkušeností s integrací a inkluzí a teprve se v celé problematice začínám orientovat... A tak si myslím, že přijetí žáků s postižením do naší střední školy by mělo přínos jak pro ně (sounáležitost, přijetí, sociální začlenění, sebeuznání), tak i pro ostatní spolužáky. Mnoho dětí dle mého názoru nemá přímou zkušenost s kontaktem s hendikepovanými lidmi. Neví, jak se k nim chovat, v mnoha případech mají mnoho zbytečných předsudků. Sdílení společného prostoru a času by je jistě do budoucího života velmi obohatilo.

3. Již díky specifikaci školy (víceleté gymnázium), která klade důraz na studijní předpoklady uchazečů, dochází k velké selekci žactva podle výkonu. Přijímacím řízením se vyprofiluje poměrně úzká skupina dětí, které toho mají poměrně hodně společného (mám na mysli například větší motivaci ke studiu nebo vyšší intelektový výkon). Zároveň je každý žák jiný, má jiné potřeby, různé předpoklady a je nutné ke každému přistupovat jednotlivě a individuálně ho rozvíjet. Vnímám to tak, že i to je ze strany učitelů inkluzivní působení.

4. Nejsem zcela přesvědčena o tom, že by všichni pedagogové, kteří působí na běžných základních školách, „ustáli“ chování a jednání dětí ze základních škol praktických. Některé z nich jsou nesmírně vulgární, bez jakékoli disciplíny, neuznávající autoritu dospělého. Někteří v případě rozrušení nemají daleko k otevřené agresi. Jak by si mnozí učitelé, ve větší míře pak učitelky, poradili stakovými žáky? Dokázali by správně reagovat $\mathrm{v}$ situacích, kdy bude znevážena jejich důstojnost, kdy se žáci naprosto nevybíravě dotknou jejich osobnosti? Na takové jednání zřejmě nejsou zvyklí - a tak by jistě nebylo od věci, abychom dříve, než zaintegrujeme žáky, zařadili naopak na nějaký čas dospělé do prostředí praktických škol. Možná by pak 
i ti, kteří tolik po společném vzdělávání volají, změnili poněkud svůj názor...

5. Učím druhým rokem. Nemohu si pomoci, veškeré řeči o integraci a inkluzi jsou podle mého názoru zcela bezpředmětné. Nevím, jestli bych to ale v naší škole před všemi kolegy s mnohaletou praxí řekla. Dle mého názoru neblahým dědictvím minulého režimu je to, že lidé s postižením v podstatě žili na okraji společnosti. Nebylo žádoucí, aby se př́liš ukazovali, vztah tzv. zdravých lidí byl k nim rozporuplný. Často znemožňoval běžnou sociální komunikaci, u hendikepovaných vytvářel pocit neúspěchu, trpkosti a nedůvěry. Proto jsem přesvědčena, že pokud chceme umožnit organizačními, technickými a s právními prostředky plnohodnotné a spravedlivé začlenění postižených do společnosti včetně společného vzdělávání všech dětí bez rozdílu jejich zdravotního stavu, musíme jim to umožnit nejprve v našich myslích a srdcích.

6. Jako žáci s poruchami chování jsou vnímáni na naší škole i žáci s ADHD, kteří nerespektují některé normy společenského chování. Jejich adaptabilita na pobyt ve školním prostředí je natolik snížena, že nejsou schopni dodržovat školní řád a režim školy. Proto jen velice těžko je lze vzdělávat ve třídách s počtem okolo 30 žáků ve třídě, bez asistence pedagoga, bez možnosti působení druhého učitele ve třídě a za použití běžně dostupných $\operatorname{metod} . .$.

7. At si to připouštíme nebo ne, nejdůležitějším prvkem při výuce zůstává stále a jedině lidský faktor - sám učitel. Můžeme mít kvalitně zpracované vzdělávací plány, můžeme disponovat spoustou názorných pomůcek, můžeme využívat nejmodernější způsoby práce, ale pokud bude stát před dětmi učitel bez pochopení pro integraci a inkluzi, bez empatie $\mathrm{k}$ dětem a jejich jedinečnosti, jsou nám všechny ostatní „výdobytky“ téměř $\mathrm{k}$ ničemu. 
Každý pedagog, který si den co den stoupá před tř́idu plnou žáků, si zaslouží obdiv a úctu. Ale přece jen: mít rád dítě hodné, snaživé, někdy nadané, slušné a bezproblémové je o něco snazší než si najít cestu $\mathrm{k}$ dětem odlišným ve všech směrech. Učitel, který má svým žákům co nabídnout, dokáže za pochodu přizpůsobit hodinu momentálnímu rozpoložení žactva. Zvládne dobře zareagovat na dítě s poruchou chování, které nechce pracovat a ještě se v hodině začne vztekat a vulgárně nadávat. Je schopen sáhnout do svého zásobníku her a technik či jiných didaktických pomůcek. Takový učitel je jistě velkým darem pro školu, na které působí, ale hlavně pro své svěřence. Proto jsem přesvědčen, že by bylo velmi dobré, kdyby již budoucí učitelé na středních pedagogických a následně vysokých školách měli do své př́ípravy na náročné povolání zařazeno více praktických předmětů. V nich by se studenti mohli seznámit s moderními přístupy $\mathrm{k}$ dětem, s terapií, diagnostikou, reedukací, ale také různými metodami, jak dítě něčemu naučit - nikoliv se zaměřit na jeden jediný způsob. Tím by měl projít každý učitel bez ohledu na to, na jakém stupni školy bude působit. Jen samotná teorie do praxe nestačí.“

8. Jsem ve školství pouhý pátý rok. Nesetkala jsem se tedy s tolika žáky s poruchou chování, ADHD, hyperkinetickým syndromem, abych mohla říci, že mám s touto problematikou plno zkušeností. Mrzí mě, že na vysoké škole se tomu profesoři na našich seminářích více nevěnovali. Ale zároveň na jejich obhajobu musím dodat, že kdybychom se tomuto tématu věnovali, tak bez praxe to nebude mít takovou váhu. Asi to záleží na každém z nás, jak je schopen si literaturu převést hned do praxe.

Já to mám tak, že literatura mi samozřejmě pomůže vysvětlit určitý pojem, ale pokud se s tím nesetkám v praxi, tak plně nepochopím podstatu. Po vysoké škole jsem šla učit na menší školu do obce, která měla asi tisíc obyvatel. Př́ijemné prostředí, menší počet žáků ve třídě, okolo sedmnácti dětí, př́ijemný 
kolektiv učitelů. Byla jsem čerstvě po státnicích, takže můžu říci, že teoretické znalosti se ještě nevytratily. Ovšem praxe dost překvapila. Pokud v hodině nastane nějaká nečekaná situace, není čas přemýšlet, co se o tom psalo v knížkách, děti čekají okamžitou reakci. Takže až zpětně si člověk přemýšlí, jak reagoval a jestli to bylo správné, či nikoliv.

Hned na této škole jsem se s pojmem integrace setkala a popravdě jsem úplně nevěděla, co vše si pod tím mám představit, co vše to bude obnášet a pro mě konkrétně znamenat. Hned na první pedagogické radě jsem zaznamenala, že se četl seznam integrovaných dětí. Neopovážila jsem se hned zeptat, ale teprve postupem času jsem díky ostatním kolegům a výchovné poradkyni zjištovala podrobnosti. Měla jsem opravdu štěstí na školu, kde jsem začínala. Pro nikoho nebyl problém mi cokoliv objasnit. Ale co kdybych začínala na velké škole, kde by na mě neměli čas a každý měl sám dost starostí se sebou?

9. Jako pozitiva integrace bych viděla navozování kontaktu se zdravými žáky, setkávání se s běžnou realitou. I to, že okusí neúspěch a někdy možná posměch může být důležité. Takový dnešní svět bohužel je. Nelze je před tím pouze chránit. Okusí proces socializace. Zároveň daný žák působí na ostatní, může odstranit předsudky vưči různým druhům postižení. Nejdříve by se ale měl pozorovat kolektiv, do kterého bude daný žák integrován, aby to nemělo opačný efekt. Pokud se integrace zdaří, pozná se to na žákovi, učitelích i rodičích. Za mě mohu říci, že nezapomenu na den, kdy maminka přišla na konci devítileté docházky do sborovny poděkovat všem učitelům, kteří tolik pomohli. Všichni měli slzy v očích. Tatínka zas nejvíc dojalo, když na školní akademii jejich syn vystupoval s ostatními chlapci ve cvičení na hrazdě a byl zdatnější než někteří jiní žáci.

Asi ne každý případ ale musí být tak úspěšný. Proces integrace může mít i svá negativa. A to finanční náročnost, někdy je 
zapotřebí osobní asistent, speciální pomůcky. Dokonce to někdy může na daného žáka klást tak vysoké nároky, že by mu bylo lépe v nějaké speciální škole. Administrativní práce školy také nelze zanedbat. Výchovná poradkyně musí neustále komunikovat jak s rodiči, tak s příslušnými poradnami, psát zprávy a informovat o tom další učitele. Domnívám se, že u každého žáka, kde se zvažuje integrace, může nastat úplně jiná fáze začlenění. Pracovnice $\mathrm{v}$ poradnách a výchovné poradkyně tedy nemají lehké rozhodování, co danému žákovi pomůže nejlépe.“

10. V loňském školním roce jsem nastoupila na základní školu a mateřskou školu. Počtem žáků (méně než 200) patří naše škola mezi menší školy, spíše „rodinného typu“. Integrovaných žáků máme 7 , dalších 25 žáků je se speciálně vzdělávacími potřebami. Jsem třídní učitelkou 5 . třídy, kam chodí 5 žáků se speciálně vzdělávacími potřebami.

Jaká pozitiva integrace vidím na naší škole? Ze zkušeností svých a svých kolegyň mohu konstatovat, že dochází k posílení sociálních vazeb mezi žáky. Žáci (alespoň v mé třídě) se snaží vzájemně si s učivem pomáhat, respektují vzájemné odlišnosti. Bylo však nutné vysvětlit žákům a následně i rodičům na společných třídních schůzkách odlišnost $\mathrm{v}$ přístupu $\mathrm{k}$ žákům (individuální přístup k žákům) a s tím související odlišnost klasifikování. V tom mi pomohly rady zkušených kolegyň, které měly negativní zkušenosti s rodiči i žáky z předchozích let. Na třídních schůzkách formou tripartit pak s rodiči probíráme individuální potřeby žáků, domlouváme se na společných krocích. Obě strany se snažíme o důslednost. U některých rodičů však bylo nutné zdůraznit, že nejen škola se podílí na vzdělávání žáků. Z posudků poradenských pracovišt vyplývají totiž také povinnosti a doporučení pro rodiče žáků se speciálně vzdělávacími potřebami. Na tripartitách se já osobně vždy ptám, jakým způsobem doporučení poraden realizují (snažím se je do spolupráce zapojit, pokud vidím, že odpovědnost přenechávají jen na 
mně). Odborný posudek sice žákovi zajistí úlevy v klasifikaci, zkrácená cvičení, více času na vypracování úloh, ale zároveň by si rodiče měli uvědomit, že o to více a pravidelně je potřeba se se žákem do školy připravovat.

Ne však v každé třídě jsou žáci ochotni pomáhat např. pomalejším žákům. V loňských letech jsme se několikrát setkali s případy, kdy se integrovaný žák, bohužel, setkal s posměchem od svých spolužáků. Pak záleží na vyučujících, na jejich postojích a postupech při práci s třídním kolektivem.

I učitelé musí věnovat svým přípravám na hodiny více času. Samozřejmostí by měla být připravená zkrácená cvičení, doplňovací cvičení, uvolňovací a relaxační techniky apod. Každý vyučující na naší škole vede deník, kam zaznamenává postřehy z výuky, konkrétně uvádí, jak uplatňoval individuální přístup k jednotlivým žákům. Je to sice někdy zdlouhavé a časově náročné zvláště, když v některé třídě je žáků se specifickými vzdělávacími potřebami více. $\mathrm{Na}$ druhé straně máme však možnost kdykoliv vedení školy, rodičům či poradnám předložit, jak se žákem pracujeme (kontrola s doporučením PPP). Deníky nám každý týden kontroluje výchovná poradkyně. Dává nám pak zpětnou vazbu, poskytuje rady a pomoc v další práci s žáky. Navýšení administrativních prací bych shledávala částečně asi jako negativum.

Naopak jako pozitivum bych ráda uvedla realizaci reedukačních hodin, které na naší škole vede výchovná poradkyně a speciální pedagog (kmenový pedagog vedle svého úvazku) na základě doporučení PPP. Na žáky je více času, žák získává prostor ke svému projevu (ústnímu, písemnému). Žáci jsou více klidnější a soustředěnější při jednotlivých činnostech. Získávají jistotu, posiluje se jejich sebedůvěra. Výchovná poradkyně spolu s vedením školy zajistila odborné publikace, cvičné listy, školení a semináře pro učitele. Odbornost pedagogů je více než nutná a je dobré, když víme, kam nebo kde najdeme radu a pomoc. 
Pokud by se zlepšila finanční stránka, byla bych ráda, kdyby se třídy mohly dovybavit potřebným variabilním nábytkem, kobercem, odpočívacími koutky, didaktickou technikou, kompenzačními pomůckami... Nedostatek finančních prostředků shledávám jako velké negativum, které nám někdy brání realizovat aktivity, které jsme schopni pro žáky připravit. Výuku bychom jim nejen zpestřili, ale také mnohdy ulehčili.

Inkluze zůstává pro naše školství velkou výzvou a záleží na nás všech, jakým způsobem se s tímto úkolem dokážeme do budoucna vypořádat. V každém případě budou potřeba již zmíněné finanční prostředky, přístup pedagogů (ochota udělat něco navíc, spolupráce pedagogů, další vzdělávání, účast na seminářích...), vytvoření pozitivního školního a třídního klimatu..., vytvoření již zmíněné, „školy pro všechny“.

11. V naší škole v rámci integrace vzděláváme dva chlapce s těžkou formou ADHD v kombinaci s poruchami chování a s disharmonickým osobnostním a sociálním vývojem. Jeden je ve čtvrté, druhý v páté třídě. Mají psychické problémy, páchají trestnou činnost. Obecně velmi špatná je spolupráce s jejich rodiči. Ti často nespolupracují, nevidí problémy svých dětí, ba snaží se je zakrývat. Jeden z chlapců je po rozvodu rodičů ve střídavé péči a otec s matkou nejsou schopni se spolu pořádně domluvit, urážejí se vzájemně před chlapcem, ten si vlastně neváží ani jednoho z nich. Druhý chlapec má staršího bratra ve vězení.

Po konzultaci s kamarádkou, která učí na malé vesnické škole, si myslím, a co víc, jsem přesvědčena, že významným přínosem pro efektivitu výuky je malý počet žáků ve třídě. Ti s poruchou chování vždy potřebují ve větší či menší míre individuální přístup, což je ve velkém třídním kolektivu problémem. Malý tř́ídní kolektiv je zároveň vhodný i pro děti s různými dalšími poruchami. V odůvodněných případech musíme naše chlapce vzdělávat odděleně od ostatních, aby nenarušovali výuku. Jedním slovem, často se ve třídě chovají tak, že je skutečně 
nejde zklidnit, že se zde prostě nedá učit. Potom jejich přítomností trpí ostatní žáci, bouří se i jejich rodiče. Ovšem vše má svá pozitiva i negativa a nelze tudíž kupř. odsoudit k zániku speciální školství díky inkluzi a integraci. Ovšem zároveň je třeba připustit, že zmiňovaná integrace má mnoho kladů a lze ji proto považovat za neodmyslitelnou součást českého školství.

12. Bohužel se ve své praxi setkávám se skutečností, že se rodiče mylně domnívají, že integrace je plně záležitostí učitele. Samozřejmě učitel se žákem pracuje a musí přizpůsobit výuku možnostem žáka, žák však nepracuje pouze ve škole, ale je potřeba pracovat i doma. Skutečnost je však mnohokrát taková, že se rodiče se žákem doma neučí, nekontrolují jeho domácí prúpravu a následně se snaží své vlastní selhání přesunout na učitele. Mnohdy se setkávám s takovými názory rodičů, jako jsou například: ale on je integrovaný a nemusí, nemůžete ho takto klasifikovat, protože on je integrovaný apod. Často význam integrace nechápou ani samotní integrovaní žáci, kteří vidí smysl integrace v tom, že upozorňují vyučujícího, že oni nemohou dostat špatnou známku, že nemusí plnit domácí úkoly ani žádnou domácí přípravu, protože na to mají papíry z poradny. Jistě nemusím zdůrazňovat, že toto není podstatou integrace.

13. Integrace s sebou mimo jiné přináší potřebu většího pracovního nasazení pedagogů, v čemž já spatřuji další úskalí. Bohužel v edukačním procesu působí také pedagogové, kteří nevědí, jak správně $\mathrm{k}$ integrovanému žákovi přistupovat. Někteří dokonce celou problematiku zlehčují a žáka jednoduše považují za hloupého. Často je to pouze jednodušší způsob, jak omluvit vlastní nezájem o žáka. Ano, integrace je časově náročnější, nebot je zapotřebí individuálního přístupu, ale pokud se člověk jednou rozhodne být pedagogem, měl by $\mathrm{k}$ tomuto poslání přistupovat zodpovědně a měl by si v první řadě uvědomit, že žákovo vzdělání a žákův postoj ke vzdělávání je do značné míry 
ovlivněn přístupem pedagoga. Je pak obrovský rozdíl mezi prací pedagoga, který přistupuje ke vzdělávání integrovaného žáka zodpovědně a respektuje doporučení odborníků pro jeho vzdělávání a mezi prací pedagoga, který toto všechno naprosto ignoruje. Mnohdy za tím stojí nedostatečná odborná znalost problematiky. Někteří pedagogové nemají základní odborné znalosti, což samozřejmě ovlivňuje kvalitu jejich přístupu k žákům.

14. Jedním z negativů integrace může být přístup rodičů, kteří si špatně vykládají význam toho, když jejich dítě pracuje podle individuálního vzdělávacího plánu. Mají pocit, že individuální plán znamená pouze úlevy pro dítě a z jejich strany tudíž nepramení žádné povinnosti pro ně ani pro dítě. Učitel, který vede reedukaci, samozřejmě rodičům vysvětluje podmínky úspěšného průběhu individuálního plánu a podrobně je s nimi seznamuje. Setkala jsem se však i rodiči, kde došlo k nepochopení významu individuálního plánu u žáka a následně tak neúspěšné spolupráci se školou. Rodiče si často neuvědomují, že když dítě má určité specifické poruchy, neznamená to automatické zohlednění ani v obsahu a znalostech daného učiva, ale ani v klasifikaci, kdy při nezvládnutí osnov daného ročníku dle jejich názoru dítě nemůže propadnout. Podceňují domácí přípravu na vyučování i plnění úkolů zadaných v navýšené reedukační hodině.

15. S odbornými pracovišti v posledních měsících spolupracujeme o něco více než dřive, a to $\mathrm{z}$ důvodu zvýšeného počtu výchovných problémů žáků. Třídní učitelé sepisují s žáky, s rodiči individuální výchovné plány. Což do jisté míry stojí učitele další čas navíc (schůzky s rodiči, sepisování smluv), ale zatím se setkáváme se zlepšením a postupným odstraňováním výchovných problémů. Uvítali bychom i spolupráci se školním psychologem a asistenty pedagoga. Ale vzhledem k nedostatečným finančním prostředkům si naše škola jejich služby nemůže 
dovolit. Zvláště bychom je uvítali ve třídách o větším počtu žáků (na prvním stupni v některých třídách až 32 žáků), kde je integrovaný žák a k tomu ještě několik žáků se specifickými vzdělávacími potřebami. Pro jednoho pedagoga je to velice náročné, jak na přípravu na vyučování, tak i v hodinách. Není pak v jeho silách, aby dostatečně uplatnil individuální přístup k žákům.“

Mezi názory učitelů na pedagogickou integraci lze nalézt některé společné prvky. Z názorů pedagogů o integrativně-inkluzivním vzdělávání vyplývá, že by bylo vhodné podpořit širší sít školních poradenských pracovišt se školním speciálním pedagogem či školním psychologem, kteří poskytují poradenskou činnost přímo na školách. Dále by pedagogové uvítali větší zastoupení asistentů pedagoga ve školách $\mathrm{s}$ integrovanými žáky. Ve spolupráci s rodiči by ocenili větší podíl některých rodičů při práci $\mathrm{s}$ dítětem $\mathrm{s}$ individuálním vzdělávacím plánem.

Dalším společným prvkem je snaha o hledání příčin problémů vznikajících při pedagogické integraci v oblasti organizační, tj. nap̌r. finanční a administrativní náročnost, obtížné navození podpơrných opatření, podmínek a vztahů v třídním kolektivu, velký počet žáků ve třídě, špatná spolupráce s rodiči, tj. zejména tzv. vnějších příčin. Jen výjimečně lze však nalézt názor pedagoga, který by vyjadřoval potřebu vlastního odborného růstu v oblasti speciálně pedagogické podpory žákovi s ADHD, což koreluje s pozitivním sebehodnocením vlastních znalostí pedagogů o ADHD uvedeným voddíle 8.3.1.9 Sebehodnocení znalostí o $A D H D$ a současně je v rozporu s výsledky našeho zjištění o znalostech pedagogů v subškále Intervence \& terapie, které byly prokazatelně nejhorší ze všech tří sledovaných oblastí, viz tabulka 14 na str. 130. Proto se autorům jevilo jako účelné zařadit do této knihy také následující kapitolu zaměřenou na vhodné pedagogické a speciálně pedagogické intervenční postupy u dětí s ADHD. 
Determinanty inkluzivního vzdèláváni dětí s ADHD 


\section{Vhodné intervenční postupy u dětí s ADHD}

Práce s dítětem s ADHD ve školním prostředí je bezesporu velice obtížná a náročná. Systematický a otevřený přístup může ovšem chování dítěte i jeho motivaci ke školním požadavkům pozitivním způsobem ovlivnit.

V odborné literatuře se setkáváme s celou řadou doporučení pro práci $\mathrm{s}$ těmito dětmi $\mathrm{v}$ rámci třídy či $\mathrm{v}$ rámci jiného sociálního prostředí. Většina z těchto přístupů vychází z kognitivně behaviorálních technik zaměřených na pozitivní modifikaci chování.

Jejich cílem je posilovat nové a žádoucí způsoby a vzorce chování za využití odměny a minimalizovat tresty.

Některé základní doporučované pedagogické postupy:

1. Instrukce a pokyny - by měly být stručné, jasné a splnitelné. Po jejich zadání by se měly vytvořit podmínky, ve kterých dítě nebude rušeno dalšími podněty.

2. Pozitivní posilování - pochvaly by měly směřovat ke všem projevům žádoucího chování. Mírné tresty používat jen v případě, že jiné řešení není účinné.

3. Mírné tresty - tresty by měly být jen mírné, jasně definované a v prímé časové souvislosti. Měly by se používat jen v případě nemožnosti jiného řešení - to je jeden ze základních prvků v intervenci zaměřené na minimalizaci projevů ADHD.

4. Častá zpětná vazba - může vést $\mathrm{k}$ zásadní změně chování dítěte. Zpětná vazba by měla být stručná a pro dítě jasná. Neměla by představovat rušivý prvek v jeho činnosti.

5. Respektování stylu učení - představuje další a zásadní prvek. Pro většinu dětí s ADHD je charakteristický tzv. 
globální styl učení. Úkoly a informace by se měly proto podávat jako celek.

6. Nácvik metakognitivních strategií - je ve své podstatě učením o vlastním stylu učení. Dítěti napomáhá získávat zpětnou vazbu a poznávat následky svých činností.

7. Sebekontrola a sebehodnocení - vede dítě $k$ regulaci jeho impulzivity a může být vhodným nástrojem $\mathrm{k}$ pozvolné změně nežádoucích vzorců v chování.

Objektivní, systematický, strukturovaný a pozitivní přístup s předem jasně definovanými pravidly je též základem ovlivnění nevhodného chování dítěte. Za základní považujeme:

1. jasně sdělené požadavky na chování žáků ve shodě s rodiči a učiteli,

2. dostatek času na vysvětlení žádoucího a nežádoucího chování,

3. jasná struktura časové jednotky,

4. předvídatelnost jednání pedagoga a jeho důslednost,

5. nácvik žádoucího chování,

6. vedení k dokončování práce,

7. pedagogovo porozumění, pružnost a trpělivost,

8. pedagogova individuální pomoc žákovi (Michalová, Pešatová 2011, s. 51-52).

Při modifikaci pozitivního chování je důležitá častá zpětná vazba. Je vhodné žáka pozitivně motivovat slovně a s úsměvem. Jednou z možností vhodnou pro první stupeň ZŠ je zaznamenávat průběh jednotlivých vyučovacích hodin např. formou smajlíků $v$ sluníčku nebo hvězdičce, které lze upravit dle počtu vyučovacích hodin, viz obrázky č. 2 a 3. Vždy záleží na kreativitě pedagoga a jeho konkrétní dohodě s dítětem. Obrázky znázorňují postupné doplňování smajlíků v průběhu čtyř vyučovacích hodin. První, druhá, třetí a čtvrtá vyučovací hodina na obrázku 2 byly úspěšné, první hodina byla méně úspěšná. Analogicky na obrázku 3 byly úspěšné první, druhá a čtvrtá vyučovací hodina, třetí hodina pak byla méně úspěšná. 


\section{Determinanty inkluzivniho vzděláváni dětí s ADHD}
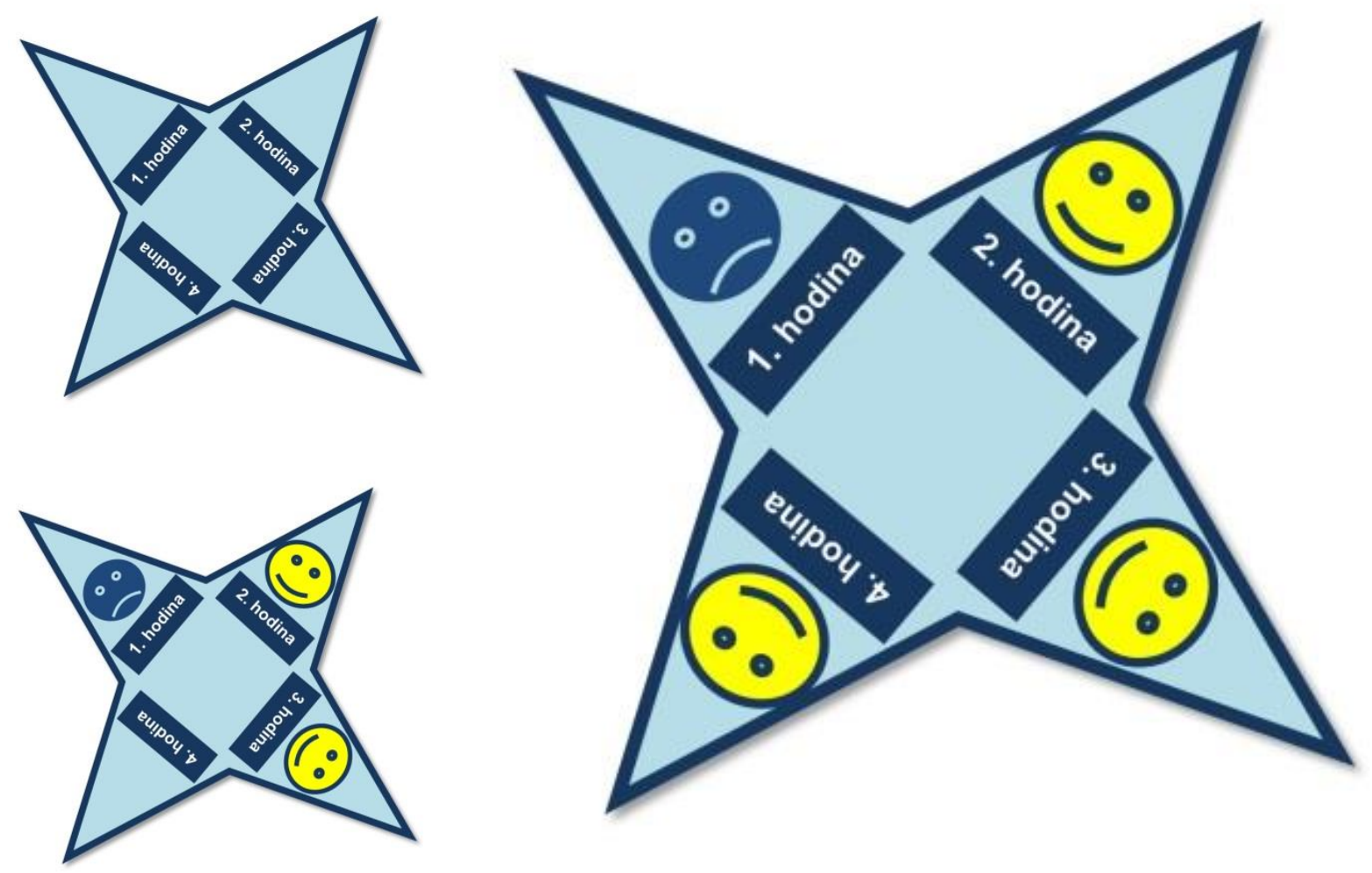

Obrázek 2: Hodnocení průběhu čtyř vyučovacích hodin pomocí smajlíků, první varianta (vlastní materiál)
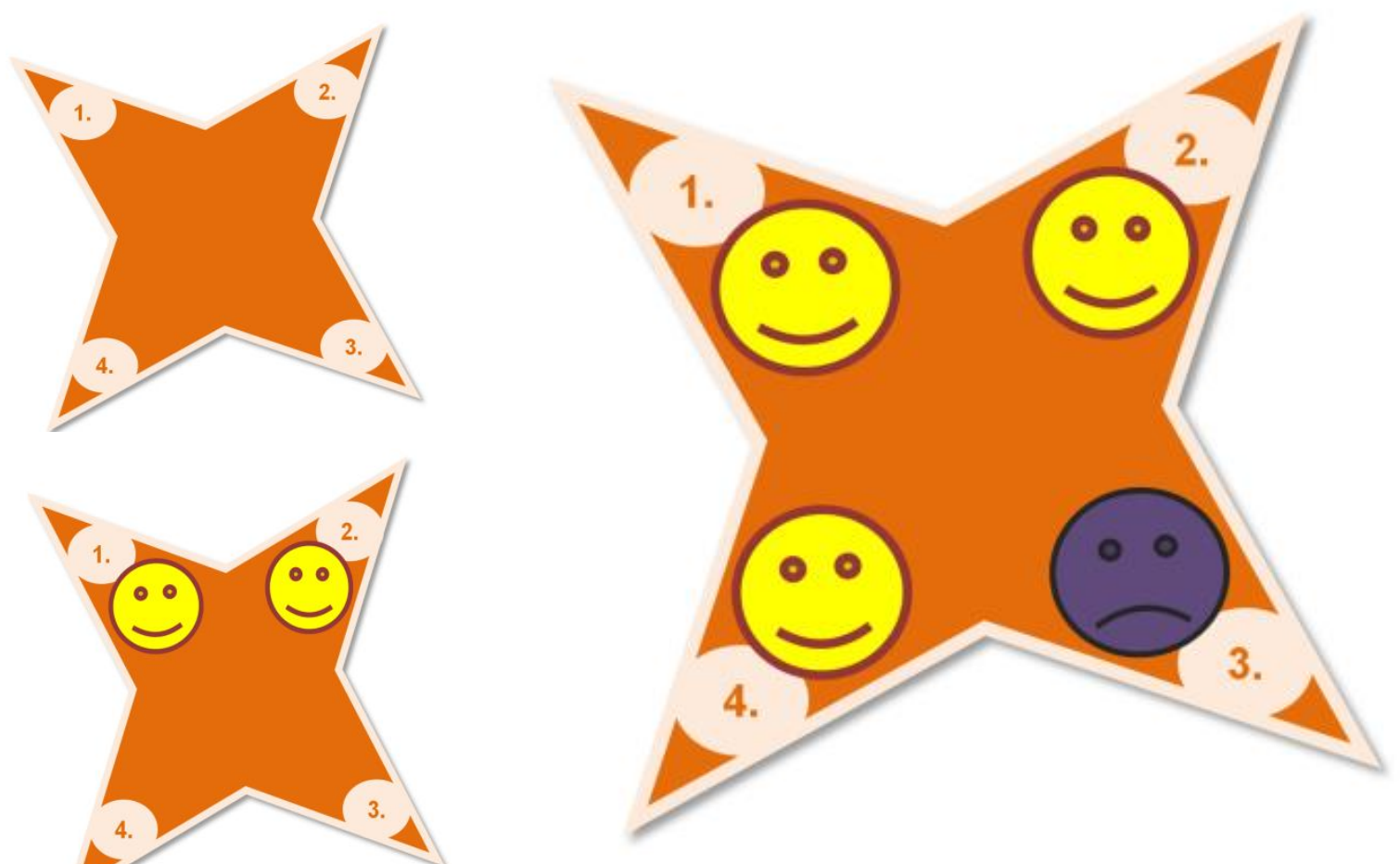

Obrázek 3: Hodnocení průběhu čtyř vyučovacích hodin pomocí smajlíků, druhá varianta (vlastní materiál) 


\subsection{Doporučení učitelům pro práci s žáky s ADHD}

Dítě potřebuje být v prvé řadě hlavně neustále povzbuzováno, motivováno a přijímáno. Trávíte s ním většinu času jeho aktivního dne, a tudíž máte velký vliv na formování jeho chování.

1. Věnujte mu pozornost, vyměňte si s dítětem alespoň $1 \times$ denně přátelské slovo. Pochvalte ho za zájem, snahu, aktivitu, zajímejte se o jeho mimoškolní činnosti a události nebo jen pochvalte nový kousek oblečení. Dejte mu možnost pocítit, že se o něj zajímáme, že vám na něm záleží.

2. Pomozte dítěti najít jeho místo $\mathbf{v}$ kolektivu, zvyšujte jeho prestiž mezi spolužáky, nepoukazujte na jeho zvláštnosti, posilujte jeho pocit prospěšnosti a významu.

3. Přizpůsobte své požadavky v rámci učebních osnov tak, aby se dostavil spíše úspěch než neúspěch. Určete mu denně nějaký dosažitelný cíl, a až jej dosáhne, dítě pochvalte. Označte barevně správné části jeho práce a oznámkujte.

4. Hranice a požadavky by měly být naprosto jasné, srozumitelné, neprostupné. Pravidel stanovíme raději méně, ale na jejich dodržování trváme. Požadavky na dítě dobře zvážíme, přihlédneme k osobním možnostem a omezením (např. ke skutečné době soustředění na jedinou činnost).

5. Při zpětném hodnocení se jeho pozornost koncentruje více na pozitivní aspekty práce. Nechte raději dítě udělat jednu část úkolu správně než celý chybně. Někdy je užitečné prověřit znalosti dítěte individuálně, mimo třídní atmosféru plnou rušivých vlivů.

6. Dovolte dětem, aby si mohly jako pomůcku k lepšímu zapamatování svých povinností vystavit nakreslené obrázky, piktogramy nebo si samy zapsaly různé body, zkratky.

7. Dítě se musí učit tak, aby se přitom učily i ostatní děti:

- číst nahlas, 
- převyprávět učební látku,

- vše několikrát opakovat.

8. Pracujte pokud možno v co nejmenších skupinkách, využívejte alternativní způsoby výuky, rozdělte děti např. do páru. Jeden je posluchač a druhý je mluvčí. V časovém limitu má mluvčí říci svému partnerovi: Co nám učitel uložil...? Nedávejte do páru dvě hyperaktivní děti!

9. U hyperaktivních dětí je nutno počítat s dvojnásobným pracovním časem, nespěchejte na kvantitu práce, zaměřte se na kvalitní výkony, které nezapomínejte vždy ocenit.

10. Dítě s ADHD se často cítí „zahlcené“ množstvím podnětů, mezi kterými nedokáže vybrat ten v konkrétním okamžiku důležitý. Mívá tak potíže se strukturováním času a prostoru. Velmi mu pomáhá, když nad řádem a strukturou $\mathrm{v}$ jeho životě bdí dospělý, vede to $\mathrm{k}$ pocitu větší jistoty, bezpečí. Časem také dítě snáze strukturu a určité pracovní postupy „zvnitřní“. Je proto vhodné zavést řád, stálejší schémata průběhu dne, přípravy do školy apod. - prosazovat je důsledně, ale zároveň vlídně, trpělivě, v atmosféře citové vřelosti.

11. Důležité úkoly, sdělení, zprávy, zadání a informace nenechávejte na poslední vyučovací hodinu. Důležitý výklad podávejte v prvních 20 minutách hodiny, taktéž i písemné práce zadávejte $\mathrm{v}$ prvních vyučovacích hodinách a hned na začátku dané hodiny.

12. Osvědčí se, pokud zkusíte sestavit jasnou strukturu rozvrhu dne a dítěti napíšete krátké a srozumitelné pravidlo chování ve škole, tělocvičně, ve školní jídelně.

13. Nikdy neposazujte spolu dvě hyperaktivní děti. Je-li to možné, posad'te dítě ve třídě co nejblíže učitelce a vzdáleněji od okna (příp. jiných míst, které snadno upoutávají pozornost), mezi klidnější žáky. 
14. Doporučujeme z dosahu či dohledu dítěte důsledně odstranit podněty $\mathrm{z}$ hlediska konkrétního úkolu rušivé nebo zkrátka „přebytečné“ (např. na lavici nechat pouze momentálně používané pomůcky).

15. Odstranění přebytečných podnětů se vyplatí „domyslet“ i v různých všednodenních situacích - zjednodušit a zpřehlednit lze např. oblékání (věci večer nachystat, v šatníku nechat jen skutečně pravidelně nošené oblečení), stolování (stálé místo u stolu, stůl bez rozptylujících drobností), ranní hygienu (vlastní kartáček s pastou a ručník na stále stejném místě, ustálené pořadí činností...) - často tak předejdeme zbytečným nedorozuměním a projevům „neposlušnosti“.

16. Lze očekávat obtíže s vykonáváním činností, které vyžadují udržení pozornosti na určitou sekvenci drobných úkonů (oblékání, úklid penálu, příprava pomůcek), a to i u dětí bystrých; pomoci může rozfázování, „naučení“ a následné zautomatizování (podobně jako u básničky nebo nové látky ve škole).

17. Každou mimoškolní aktivitu je nutné předem sdělit a ve všech bodech s žáky prodiskutovat. Každá změna se sděluje v klidu.

18. Dítě bývá často pod silným vnitřním tlakem, proto má tendence se bez ustání kývat, hučet, vyrušovat. Pokuste se zůstat klidní. Domlouvat v tuto chvíli dítěti je neúčinné. Podobné to je i při prudších emocionálních reakcích. Je třeba počkat, až se dítě uklidní, potom je možné s ním předchozí situaci rozebrat.

19. Každá prudkost by měla být zmírněna. Při hyperaktivním chování žáka se snažte zůstat klidní a nezvyšujte hlas. Na jeho projevy reagujte vždy tiše, klidně. Používejte přímé, krátké a výstižné věty. Důležité pokyny je třeba ještě zesílit pomocí očního nebo tělesného kontaktu (nap̌r. položením ruky na rameno, přistoupením k lavici žáka). 
20. Pokud dítě porušilo pravidlo, nereagujte posměchem nebo rozčileně. Ačkoliv tato chyba nemůže být prominuta, uvědomte si, že je to jeden z příznaků jeho poruchy. Zeptejte se dítěte, jaké pravidlo bylo porušeno. Je-li to nutné, formulujte pravidlo ještě jednou. Potom proved'te potrestání, které musí být účinné, uvědomělé, dále se však o něm nemluví. Návrat do pozitivních interpersonálních vztahů je základem a podmínkou další spolupráce.

21. Jako trest se nesmí užít žádné opatření, které by dítěti omezilo jeho základní životní potřeby. Přestávky a možnosti pohybu nesmí být kráceny. Dodatečné úlohy, které vyžadují ještě více pozornosti navíc, také nejsou vhodným řešením. Zde se lépe osvědčí důsledný systém odměňování pomocí bodů, který se denně zapisuje a na konci týdne vede k zaslouženému výsledku. Body, které jsou odečteny pro určité nedostatky, je nutno předem s dítětem prohovořit a zároveň dítě naučit, jak jim příště předejít.

22. Zpětnou vazbu poskytujeme častěji, konkrétně, pozitivně např. co přesně se nám líbí. Možná dítě ve výkresu vybralo zajímavé barvy, uplatnilo fantazii, soustředilo se celých 10 minut, dokončilo již úkol.

23. Napomínáme-li, místo kritiky raději sdělíme, jak si přejeme, aby dítě jednalo (např. namísto „zas tu máš nepořádek“ raději „ten kelímek od vodovek už nepotřebuješ, prosím, uklid” ho do svého kufř́iku“, nejlépe následováno „správně, vidíš, jak ted' tvoje lavice prokoukla“.)

24. Pozitivní posilování (úsměv, pohlazení, pochvala) - ihned po splnění úkolu, po chování, které bylo žádoucí, zralejší, líbilo se nám... Pochvaly se vztahují i na úkoly, které by měly být zvládnuty dětmi v nižším věku. Pozitivních zpětných vazeb by se dítěti mělo dostat alespoň dvakrát více, nežli těch negativních. $\mathrm{V}$ běžných každodenních situacích je proto vhodné příležitosti k pochvale a kladným zpevněním aktivně „vyhlížet“ (zatímco příležitosti ke kritice se často „hledají samy“). 
25. Je dobré zadat hyperaktivnímu dítěti nějakou malou povinnost, pověřit ho nějakým stálým úkolem pro třídu nebo ho nechat něco vyřídit, přinést, smazat tabuli aj.

26. Domluvte si s dítětem gesto, které mu vždy připomene, že se má utišit. Pokud dítě gestu rozumí, reaguje na ně velmi vděčně, a je tak znovu motivováno. Učte děti dávat pozor na neverbální podněty, aby se udržely při své práci bez přerušení vyučování.

27. Při silném neklidu při vyučování je možné zařadit relaxační chvilky, uvolňovací sekvence pomocí her zacílených na tělesné vjemy, prožitky apod. (chvíli položit hlavu na lavici, nechte ho v lavici polohovat, klečet, možnost odpočinku na koberci apod.).

28. I o přestávkách lze provádět bohaté pohybové činnosti s důrazem na bezpečnost dětí.

29. Domácí úkoly se zapisují každý den do notýsku, který sledují a kam se podepisují rodiče. Druhý den ráno splnění úkolu kontroluje učitel: to ušetří mnoho zbytečných diskusí rodičům i učitelům.

30. Úkoly zadáváme jednoduché, splnitelné a krátké, složitější rozdělíme na kratší úseky a zadáme je postupně; po zadání úkolu vytvoříme takové podmínky, aby bylo dítě co nejméně rušeno.

31. V neposlední řadě bud'te velmi tolerantní k psychomotorickému neklidu, zvýšené pohyblivosti, impulzivním reakcím, příp. pomalejšímu pracovnímu tempu a dalším charakteristickým obtížím plynoucím z poruchy - v tomto věku jsou stěží ovlivnitelné zvýšeným úsilím dítěte (resp. spíše krátkodobě a v závislosti na konkrétní situaci).

32. Při setkání s rodiči dítěte myslete na to, že se rodiče nesoustředí pouze na informace o výsledcích dítěte v učení, ale i na váš přístup k němu. Pro rodiče je důležité, aby mohli být na své dítě pyšní a aby je uklidnilo, že jejich dítěti rozumíte v jeho problému a že mu chcete pomoci. Hledejte 
proto také hodně pozitivních informací, které jim můžete sdělit.

33. Důležité je ocenění a využití pozitivních vlastností těchto dětí, jako jsou:

- smysl pro spravedlnost,

- pohotová pomoc a starostlivost,

- radostná tvorba,

- otevřenost a upřímnost

- schopnost odpouštět (Hlavová, Šuková 2014).

Žáci s ADHD mívají často problém se zapamatováním si pokynů a s plánováním času. Z tohoto důvodu jsou vhodná následující doporučení dle Cartera:

1. Do rozvrhu domácích úkolů zapracujte orientačně počáteční a konečný čas, aby žáci úspěšně pracovali s časem a mohli jej sami sledovat. To je povzbudí v soustředění na to, aby u úkolu vydrželi.

2. Rozdělte školní projekty a domácí úkoly a připojte ke každé položce odhad času, který bude zapotřebí k dokončení každé aktivity nebo práce, nebot tyto děti často nesprávně hospodaří s časem.

3. Snažte se vydávat pokyny pokud možno v klidném prostředí. Neříkejte dítěti: „Už jsem ti to říkal...“ protože vás pravděpodobně neslyšelo. Prostě pokyn zopakujte normálním tónem.

4. Dívejte se dítěti do očí a chvalte ho, když úkol dokončí.

5. Děti si mohou zapisovat úkoly pomocí snadno zapamatovatelné poznámky, když budou používat obrázkové organizéry, nabídněte mu vizuální nápovědu.

6. Kontrolujte kalendáře a poznámkové bloky se zapsanými úkoly, děti s ADHD mají sklon zapisovat úkoly na nesprávné dny (Carter 2014). 


\section{Příklad denního rozvrhu}

Napiš seznam činností a přiděl jim stupeň důležitosti:
A. musím udělat - je to nutné, nezbytné, nejdůležitější,
B. měl bych udělat - je to velmi žádoucí (moje povinnost),
C. mohl bych udělat - můžu udělat.

Tabulka 26: Příklad denního rozvrhu

\begin{tabular}{|l|l|l|l|}
\hline $\begin{array}{c}\text { A, B } \\
\text { nebo } \\
\mathbf{C}\end{array}$ & Čas & \multicolumn{1}{c|}{ Činnost } & $\begin{array}{c}\text { Odhad } \\
\text { potřebného } \\
\text { času }\end{array}$ \\
\hline$A$ & $16: 00$ & Domácí úkol z matematiky & $30 \mathrm{~min}$ \\
\hline & & & \\
\hline & & & \\
\hline & & & \\
\hline & & & \\
\hline & & & \\
\hline
\end{tabular}

\section{Příklad učebního plánu pro 2. stupeň ZS̆}

Tabulka 27: Př́íklad týdenního učebního plánu pro 2. stupeň ZŠ: Vypracování referátu na zadané téma - kategorie $\mathrm{A}$. = musím udělat - je to nutné

\begin{tabular}{|c|c|c|c|c|}
\hline $\begin{array}{c}\text { A, B } \\
\text { nebo C }\end{array}$ & $\begin{array}{c}\text { Čas } \\
\text { pŕipravy }\end{array}$ & Zdroj & $\begin{array}{c}\text { Odhadovaný } \\
\text { čas }\end{array}$ & Jiné \\
\hline \multirow{2}{*}{$A$} & $\begin{array}{c}\text { Ponděli } \\
16: 15 \text { hod }\end{array}$ & $\begin{array}{c}\text { Knihy } \\
\text { zknihovny }\end{array}$ & 2 hodiny & $\begin{array}{c}\text { Zajet do } \\
\text { knihovny }\end{array}$ \\
\hline & & & & \\
\hline & & & & \\
\hline & & & & \\
\hline & & & & \\
\hline & & & Cas celkem: & \\
\hline
\end{tabular}




\subsection{Individuální výchovný plán}

Individuální výchovný plán (IVýP) je dokument, který nemá sice právní vymahatelnost, ale lze jej zařadit mezi nástroje, které v případech zvyšujících se výchovných problémů žáků nastaví spolupráci rodiny, školy a ostatních orgánů a institucí ve směru vyřešení těchto problémů. IVýP je dohoda s rodiči nebo zákonnými zástupci (dále jen rodiče), u jejichž dětí se objevují opakované výchovné problémy, přestupky proti školnímu řádu nebo pravidlům třídy, které negativně působí na proces vzdělávání konkrétního jedince i celé třídy.

V Evropě využívají obdobného nástroje standardně hlavně německy mluvící země a ve Velké Británii jsou smlouvy s rodiči povinné a prý velmi účinné. Právě modely z Velké Británie naše ministerstvo velmi zaujaly tím, že nejsou postaveny na sankcích, ale na pomoci rodičům a na metodické podpoře učitelů, kteří si také bohužel někdy nevědí rady, protože nemají dostatek zkušeností a informací, případně nemají tak silnou osobnost, aby problém zvládli sami (Švancar, 2011b).

IVýP se vytváří v situaci, kdy běžná opatření nevedla k efektu. Obsahuje reálné úkoly a závazky pro školu, rodiče i samotného žáka. Nepredstavuje jednorázovou akci spočívající v podpisu „smlouvy“ školy s rodiči, ale jde o celý systém, jak pracovat se žáky v oblasti výchovy ve škole a zejména se zaměřením na prevenci a řešení poruch chování (MSMT-43301/2013).

Tento plán sice nebyl prvoplánově určen pro mateřské školy, ale vzhledem k objevujícím se závažným obtížím v chování již i v této věkové kategorii se ukazuje jeho funkčnost i zde. Chceme-li takový plán $\mathrm{v}$ př́ípadě potřeby postavit i pro dítě v mateřské škole, bez akceptování vývojových zvláštností určitého věku ho lze jen těžko postavit. To platí pro jakýkoli kvalitní individuální výchovný či individuálně výchovně vzdělávací plán. Vcítit se do dětského světa, akceptovat jej a být při tom sám sebou jsou ostatně obecné podmínky 
optimálního rozvoje dítěte formulované současnou psychologií proklamující humanistické ideje přístupu zaměřeného na člověka (Rogers 1998).

Termín individuální výchovně vzdělávací plán sice naše školská legislativa nezná, domnívám se však, že je to vhodný termín pro případ, kdy je potřeba individuální plán pro dítě sestavit a v centru jeho problémů se objevují nejen výchovné, ale i vzdělávací problémy.

Přesto dochází $\mathrm{k}$ situacím, že některé dítě či žák po nástupu do školské instituce vzhledem k svým obtížím v chování, at organického či neorganického původu, potřebuje důraznější podporu při svém směrování. Jeho projevy jsou natolik v rozporu se stanoveným školním řádem, že je nezbytné sestavit písemně jakousi smlouvu mezi rodiči, dítětem či žákem a školským zařízením. Obsahuje postupy, které by měly vést $\mathrm{k}$ nápravě, pokud je všechny zúčastněné strany budou skutečně dodržovat. Základem je domluvit se na reálnosti obsahu těchto plánů.

Hlavní zásadou podpory dítěte by měla být jeho pozitivní motivace založená na opravdovosti přesvědčení, že společnými silami vše zvládneme. Obecně by bylo při tvorbě plánů vhodné řídit se pravidlem: Nespravuj, co není rozbité, dělej více toho, co se daří, místo toho, co nejde, dělej něco jiného.

\subsubsection{Ověřování individuálního výchovného plánu}

Ministerstvo školství, mládeže a tělovýchovy vyhlásilo ve školním roce 2011/10 pokusné ověřování funkčnosti tohoto plánu, a to na základě $§ 171$ odst. 1 zákona č. 561/2004 Sb., o předškolním, základním, středním, vyšším odborném a jiném vzdělávání (školský zákon). Při ověřování se zabývalo novou formou školní péče o žáky vedoucí $\mathrm{k}$ prevenci projevů rizikového chování a v případě jejich propuknutí $\mathrm{k}$ jejich řešení pomocí nastavených postupů s využitím IVýP, a to 
včetně meziresortní spolupráce. Byly vymezeny následující oblasti, kterými se pokusné ověřování funkčnosti IVýP přednostně zabývalo.

\section{Ze strany žáka}

1. Neplnění školních povinností

- nenošení pomůcek,

- bez domácích úkoli̊,

- záškoláctví,

- odmítání práce při vyučování.

2. Nevhodné chování

- hrubé vyrušování při vyučování,

- vulgární chování,

- nevhodné chování ke spolužákům, zaměstnancům a k ostatní veřejnosti při akcích školy (agresivita, násilí, šikana včetně kyberšikany),

- vandalismus,

- kriminalita, delikvence (např. krádeže),

- xenofobie, rasismus, intolerance a antisemitismus,

- nevhodné chování se sexuálním podtextem.

3. Další typy rizikového chování

- kouření včetně poskytování cigaret ostatním,

- užívání návykových látek včetně jejich poskytování ostatním,

- pití alkoholu včetně jeho poskytování ostatním,

- nošení nevhodných a nebezpečných předmětů do školy,

- netolismus.

\section{Ze strany rodičů}

- nedostatečná kontrola školních výsledků dítěte,

- nedostatečná spolupráce se školou,

- nevhodný příklad,

- ohrožování výchovy dítěte,

- psychické nebo tělesné týrání, 
- nevhodné chování se sexuálním podtextem,

- zneužívání formou vlivu sekt a náboženských hnutí.

\section{Ze strany školy}

- nedostatečná či nevhodná spolupráce a komunikace s rodiči a žákem,

- nedostatečná kontrola žáka,

- nedostatečná pomoc žákovi,

- nerespektování důstojnosti žáka.

Do ověřování IVýP se zapojilo 36 pilotních škol. Jeho tvorbu využily pro 676 žáků - 208 na prvním a 468 na druhém stupni.

Pozitivní změna byla zaznamenána v 566 případech (necelých 84 \%). Školy uložily 676 individuálních plánů pro nezvladatelné žáky. U 160 případů ze zmíněných 676 uzavřely školy smlouvu s rodiči, v níž se otcové a matky zavázali ke spolupráci. Z pokusného ověřování ovšem také vyplynulo, že skutečnost uzavření individuálního výchovného plánu v písemné podobě nevypovídá o tom, co konkrétně pro nápravu výchovných obtíží určitého žáka opravdu učitelé a rodiče udělali, jak kompetentně se angažovali při řešení problému (Mertin 2013).

\subsubsection{Tvorba individuálního výchovného plánu}

Individuální výchovný plán se sestavuje na základě zprvu ústního projednání určitého problému na půdě školy s rodičem a dítětem. Problém k řšení se zcela jasně označí, tím si ho lépe uvědomí i rodiče. Následně se stručně sepíše formou dohody, kdy si dítě řekne, co by chtělo zlepšit, učitel slíbí, jak mu v tom pomůže, a rodiče se zavážou k tomu, že to budou kontrolovat, že budou v kontaktu se školou a jak sami k řešení problému přispějí.

Děti s ADHD srovnatelné podle neurologických vyšetření a psychologických ukazatelů v hloubce svých obtíží vykazují odlišné problémy ve svém chování. Souvislost spatřujeme vodlišných podmínkách 
uvnitř rodiny, v nichž takové dítě vyrůstá. Ve škole mají rodiče za děti nepřímou odpovědnost, proto když se objeví problém v chování na půdě školy, je v prvé řadě na učiteli, aby pro dítě vymýšlel a nacházel podpůrná opatření vedoucí k jeho zlepšení.

Nezletilý žák je jen z malé části odpovědný za své chování ve škole, proto záleží na dospělých, aby mu nastavili pravidla chování a směrovali ho k naplnění takto stanovených požadavků v jeho každodenním chování.

Individuální výchovný plán obsahuje tedy postup kroků, které mají škola, dítě a případně i rodiče ke změně problémového chování udělat. Nenabízí žádný striktně stanovený postup, ale poskytuje obecnější přístup k prevenci i řešení určitých výchovných obtíží ve školním prostředí. Staví na individuálním řešení konkrétního problému konkrétního dítěte/žáka za podpory jeho rodičů. Specifikuje konkrétně aktivity všech, kteří se podílejí nejen na jeho tvorbě, ale především na následné realizaci, tj. aktivity školy, rodiny i samotného dítěte/žáka. Předpokládá se, že obsahem bude dle potřeby vyspecifikovaná podpora institucí, s nimiž škola může spolupracovat. Konkrétně se jedná o OSPOD, pedagogicko-psychologické porady, speciálně pedagogická centra, střediska výchovné péče, dětské lékaře... Principy IVýP jsou inspiračně využitelné i pro ty, kteří se tvorbou konkrétního plánu nechtějí zabývat.

Je potřeba si uvědomit, že IVýP je rekrutován na jiných principech než individuální vzdělávací plán, $\mathrm{k}$ němuž je někdy připodobňován. Jeho tvorbě by měla předcházet intervence, která nebyla ale do této doby úspěšná, a to ani opakovaně, přes detailnější konkrétní doporučení dítěti daná učitelem, co by mělo dělat, aby jeho chování a jednání bylo pro školní prostředí přijatelné, přes snahu do řešení již zapojit rodiče, kteří pouze přislíbí pomoc, ale často se zavřením dveří školy zapomenou, že něco učiteli slíbili. Pokud nepomohou ani opakované konzultace realizované ústní formou, nefungují ani pravidelné 
porady s rodiči ve škole s častější frekvencí setkávání, pak je potřebné, resp. vhodné koncipovat konkrétní návrhy opatření v písemné formě. Sepsání IVýPu by tedy mělo sdělit, že se dosud určitý konkrétní problém v chování nepodařilo vyřešit přes předchozí intervenční opatření.

Nejprve je však důležité, aby učitelé došli s rodiči ke shodě v pohledu na chování jejich dítěte. Pokud rodiče prohlašují, že doma nemají problém s chováním dítěte, může skutečně jednou z příčin tohoto jevu být specifičnost školní atmosféry pro dítě, souvislost s kontaktem žáka pouze s určitým učitelem. Učitel také může mít neadekvátně posunuté normy pro hodnocení přestupků tohoto žáka. Často se však jedná o výskyt stejně problémového chování dítěte i v domácím prostředí, které se doma eliminuje tím, že si dítě může skutečně zde dělat pouze to, co chce a co ho baví. Rodiče mívají výrazně posunuté normy pro hodnocení chování svého dítěte a velmi často jej nekriticky omlouvají. Setkáváme se však také s případy, kdy problémy v chování se vyskytují i doma, ale rodiče se to obávají přiznat na půdě školy i poradenského pracoviště.

Ve srovnání s individuálním vzdělávacím plánem je třeba u individuálního výchovného plánu stanovit častější termíny pravidelných setkávání zúčastněných stran nad jeho efektivitou, a to někdy i každý týden. Společné působení se snahou o změnu v chování vychází z důslednosti účastníků. Při nízké frekvenci setkávání se snižuje schopnost dodržovat slíbené a při setkávání na půdě školy se posiluje volní úsilí účastníků je dodržet. Netýká se to pouze rodičů a žáka, ale často i učitelů.

\subsubsection{Ukázky individuálních výchovných plánů}

Individuální výchovný plán obsahuje individualizovaný př́istup obsahem návrhů a možnostmi řešení problémů konkrétního žáka. Umožňuje rodičům se podílet na řešení školních problémů jejich 
dítěte zcela operativně a konstruktivně, nemá za cíl kritizovat jejich výchovné postupy.

Může dojít i k tomu, že rodiče odmítnou smlouvu podepsat. Není možné je $\mathrm{k}$ tomu nutit. Škola rodičům $\mathrm{v}$ takovém případě sdělí, jak bude tedy sama postupovat a jaké budou další kroky v případě, když opatření nebude stačit $\mathrm{k}$ vyřešení problému jejich dítěte (Mertin, Krejčová, 2013, s. 162-168). 
10.2.3.1 Ukázka č. 1

Individuální výchouný plán

V Praze dne

Jméno žáka: David

Bydliště: Praha

Škola, třída: ZŠS třída 9.

Popis řešeného problému:

- těžká forma $\mathrm{ADHD}$, nepřiměřené neočekávané agresivní reakce, rituální chování.

Podpůrná opatření ze strany školy:

1) Zprostředkování kontaktu a komunikace s vrstevníky - asistent mediátor.

2) Nutnost obeznámení spolužáků s problematickým chováním Davida.

3) Strukturování vyučování.

4) Eliminace nežádoucích projevů chování - nácvik odchodu ze třídy pod vedením asistenta.

5) Nácvik sociálních dovedností s akceptováním sociálních možností dítěte - etoped.

6) Strukturovaná pracovní plocha.

7) Strukturovaný systém hodnocení chování a učení.

Podpůrná opatření ze strany rodiny:

1) Před odchodem do školy zajistí rodiče podání medikamentů chlapci.

2) Každý den prohlédnout aktovku z důvodu minimalizace nošení nevhodných předmětů do školy.

3) Dostupnost rodičů po telefonu.

4) Při nezvladatelném afektu rodiče zajistí odchod chlapce ze školy.

5) Rodiče souhlasí v situacích výrazného omezení bezpečnosti žáka i vrstevníků včetně učitelů se zavoláním záchranné služby. 
6) Strukturovaný systém hodnocení chování a učení bude probíhat dle stejných pravidel v domácím i školním prostředí.

7) V případě potřeby rodiče zajistí průběžnou psychiatrickou péči.

\section{Úkoly pro žáka:}

1) Pravidelné užívání medikace předepsané lékařem.

2) Dobrovolné trávení přestávek s vrstevníky za dohledu asistenta pedagoga.

3) Ráno - odevzdávat v ředitelně mobil.

4) Souhlasit s prohlédnutím školní tašky při příchodu do školy z důvodu kontroly jejího obsahu - zamezit nošení nebezpečných ostrých předmětů.

Pozitivní důsledky, když se podaří naplnit cíle:

1) Zlepšení přijetí vrstevnickou skupinou.

2) Zlepšení prospěchu.

3) Nedochází k perzekucím v oblasti hodnocení chování.

Opatření, když se nebude dařit průběžné i konečné cíle naplňovat:

1) Individuální vzdělávání s podporou dětského psychiatra.

Spolupráce s jinými odborníky či odbornými pracovišti:

- SPC, dětská psychiatrie, OSPOD.

Termíny schůzek:

Konzultace s rodiči se uskuteční $2 \times$ za měsíc, vždy v pondělí v 16:30. Konzultace vyučujících s asistentem pedagoga dle potřeby. Další výchovně - vzdělávací postupy je možné konzultovat s pracovníky SPC.

Za školu podpis garanta: $\quad$ Podpis rodičů: $\quad$ Podpis žáka: 
10.2.3.2 Ukázka č. 2

Individuální výchouný plán

V Praze dne

Jméno žáka: Eliška

Bydliště: Praha

Škola, třída: Ž̌ , tř. 2.

Popis řešeného problému:

- $\mathrm{ADD}$, neplnění domácích úkolů - nechce je psát sama, odmítání písemných prací ve třídě.

Podpůrná opatření ze strany školy:

1) Zkrácený rozsah úkolů ve srovnání s vrstevníky.

2) Zkrácený rozsah písemných cvičení, preference doplňovacích cvičení.

3) Prodloužený čas na práci ve srovnání s vrstevníky o 25 \%.

Podpůrná opatření ze strany rodiny:

1) Stanovit přesnou dobu psaní domácích úkolů.

2) Podpora děvčete při zpracování domácích úkolů ze strany rodičů

- přítomnost rodičů, podpora prvního kroku... Pomoci takto Elišce překonat překážku, když si nevěří nejen doma, ale i ve škole. Pokud Eliška obtížně zvládne přidělený úkol, zvyšuje se pravděpodobnost vzniku problému v chování - přestane pracovat, bude rušit, afekt... Včasná dopomoc minimalizuje uváděné chování

\section{Úkoly pro žáka:}

1) Zpracovávat pravidelně domácí úkoly bez průvodních scén.

2) Zapisovat si jejich zadání a ukazovat zapsání znění paní učitelce.

Pozitivní důsledky, když se podaří naplnit cíle:

1) Zvýšení doby hraní deskových her v domácím prostředí s rodiči.

2) Zlepšení prospěchu. 
3) Odpadne obava z nesplnění úkolu a ranní nevolnosti při odchodu do školy.

Opatření, když se nebude dařit průběžné i konečné cíle naplňovat:

1) Psaní domácích úkolů ve školní družině.

2) Pokus navázat kontakt s pěti $P$.

Spolupráce s jinými odborníky či odbornými pracovišti:

- SVP - posilování volních vlastností.

Termíny schůzek:

Konzultace s rodiči by se měly uskutečňovat minimálně jedenkrát za 14 dní. Další výchovně - vzdělávací postupy je možné konzultovat s pracovníky SVP.

Za školu podpis garanta:

Podpis rodičů:

Podpis žáka: 


\subsubsection{Ukázka č. 3:}

\section{Individuálni výchouně-vzdělávací plán pro mateřskou školu}

Jméno a př́ijmení: Šimon Ponravička (jméno smyšleno)

Datum narození: 13. 12. 2009 (smyšleno)

Bydliště:

Mateřská škola: MŠ XY, Horní Bruníkov (smyšleno), tř. 3.

Učební dokumenty:

Školní vzdělávací program , " ̌̌.j.

Závěry z odborného pracoviště z vyšetření dne: 25. 4. 2015

- Rozumové schopnosti - nerovnoměrný vývoj jednotlivých rozumových schopností, celkový výkon zatím podprůměrný. Potenciál je bezpochyby vyšší. Bude však záležet na tom, v jakých podmínkách se bude dál život dítěte odvíjet. Úroveň percepčních funkcí je na nižší úrovni. Limitem je i nízká úroveň pozornosti a obtížnější spolupráce s dítětem. Projevy chování poukazují na specifickou poruchu chování, susp. ADHD. Labilní, citově deprivované dítě. Nutná psychoterapeutická a sociálněprávní podpora matky. Kontrolní vyšetření plánováno na duben 2016, v př́ípadě potřeby možno i dříve.

\section{Podpora asistentem: ano}

- Popis péče z hlediska podpory asistentem viz posudek podpory vydaný pracovištěm SPC - doba platnosti posudku do 31. 8. 2016.

\section{Výchovná opatření:}

1) Při přátelském, ale nekompromisním vedení zvládne Štěpán více, než pokud si vynutí nepřiměřenou volnost rozhodování. Je vhodné stanovit jednoduchá pravidla, pro chlapce pochopitelná, zprostředkovaná vizuální formou - obrázkem či fotografií, znázorňující dané pravidlo. Nutné je poskytnout Štěpánovi zpětnou vazbu o jejich dodržování, opět nejlépe podpořené 
vizuální formou např. záznam sluníčka při sociálně vhodném chování.

2) Cíleně učit Štěpána zvládat afektivní chování - nutnost postupného nácviku, který by měl vést k vyšší kontrole chování. Navrhujeme metodu nácviku zklidnění při afektu, s dalším uvědomováním si svých potřeb.

3) Zaměřit se na osvojení základních hygienických pravidel - dodržování čistoty po toaletě, při jídle.

4) Veškeré požadavky budou chlapci předkládány strukturovaně a srozumitelně. Je nutné zviditelnit čas určený na práci a soustředění a čas na odpočinek a relaxaci.

5) Vycházet z jasných a přehledných pravidel pokud možno s vizuální oporou např. obrázky, fotografie zachycující stanovené pravidlo.

6) Vedení k reflexi svého chování, cíleně zařazovat nácvik sociálních dovedností. Zaměřit se na rozbor sociálních situací na vyprávěném/čteném příběhu, pohádce. Chlapec se při vhodně zvolené pohádce nebo příběhu může identifikovat s postavou a lépe porozumět vlastním pocitům. Může snáze pochopit souvislosti i nalézt ponaučení pro své vlastní chování.

7) Respektovat to, že chlapec není plně schopen generalizace. Znamená to, že informaci, popř. pravidlo, které si osvojil v řešení jedné situace, nemusí umět použít v situaci podobné.

8) Oceňovat a hodnotit chování za menší časové celky v průběhu dne, konkrétně za dopolední a odpolední činnost. Hodnocení bude krátké, pochopitelné pro chlapce, tedy vizuálně vyjádřené obrázkem (obličej s různým typem výrazu - usměváček, mračoun apod.).

9) Zařadit cvičení na nácvik pozornosti.

10) Zařazovat psychorelaxační cvičení.

\section{Vzdělávací opatření:}

1) Zaměřit se na rozvoj percepčních funkcí - sluchového a zrakového vnímání a nácvik koncentrace.

2) V rámci předškolní výchovy se zaměřit na:

o Rozvoj grafomotriky - uvolňovací cvičení horní končetiny. 
○ Rozvoj zrakového vnímání, uvědomování si odlišnosti dvou podobných tvarů.

○ Rozvoj sluchového vnímání - nácvik sluchové analýzy tzn. rozeznání první, event. poslední hlásky ve slově.

- Nácvik koncentrace optimálně např. s programem HYPO.

- Nácvik relaxace a uvolnění např. zařazení cvičení v rámci dětské jógy.

Konkrétní obsah IVP: viz příloha IVP

Nezbytné kompenzační a učební pomůcky, vybavení:

1) Dětské encyklopedie.

2) Šimonovy pracovní listy.

3) Bednářová, J: Prostorová orientace.

4) Housarová, Šulistová: Logopedická cvičení.

5) Bednářová: Zrakové vnímání I.

6) Michalová: Shody a rozdíly.

7) Michalová: Čáry máry I., II.,

8) Pracovní listy pro MŠ.

9) Pomůcky na jemnou motoriku (količky, mozaiky, hříbečky), terapeutická hmota, trojhranné pastelky, prstové barvy.

10) Logico Picolo - tabulka a soubory pracovních listů.

11) Pomůcky pro rozvoj sociálních dovedností.

12) Pomůcky pro strukturování vyučování, obrázkové přehledy činností.

\section{Účast dalšího pedagogického pracovníka:}

- asistent pedagoga.

Předpoklad navýšení finančních prostředků:

- Asistent pedagoga: Kč 96 000,-

- Pomůcky: Kč 4 830,-

Spolupráce se zákonnými zástupci:

- Konzultace s matkou $1 \times$ za 14 dní v mateřské škole, vždy v pátek, v 16:00. V případě nutnosti častějších setkání bude 
matka požádána o schůzku ředitelkou školy. Matka bude o termínech setkání informovaná předem.

\section{Podíl dítěte na řešení problému:}

- Chlapec je veden ke spoluzodpovědnosti za řešení problémů v MŠ adekvátně věku a úrovni rozvoje a k prosociálnímu řešení situací v rámci interakce s ostatními dětmi - uvědomování si potřeby pomoci mladším dětem a dále $\mathrm{k}$ vyžádání si dopomoci v případě, že ji potřebuje.

Jmenovité určení pracovníka poradenského zařízení spolupracujícího se školou:

1) Mgr. Alexandra Voláčková (smyšlené jméno)

Vyhodnocení funkčnosti opatření:

- 15. 12.2015 a 31. 5. 2016,

- za přítomnosti všech níže podepsaných, a to v mateřské škole.

Na vypracování plánu se podíleli:

1) speciální pedagog SPC (jmenovitě),

2) učitelky MŠ (jmenovitě),

3) matka dítěte (jmenovitě).

\section{Podpisy:}

Datum: V Praze dne

Ředitelka MŠ

Učitelka MŠ

Zákonný zástupce
Učitelka M ̌̌

Asistent pedagoga

Odpovědný pracovník poradenského zařízení 
P̌̌ÍLOHA K IVP - konkrétní rozsah a organizace podpory a péče v rámci IVP

Úprava a organizace výuky

1) Dobrá dostupnost k učiteli.

2) Strukturace režimu dne.

3) Individuální podpora asistentem.

Časové a obsahové rozvržení učiva

1) Podle rozpracovaného měsíčního plánu.

2) Vyvozování a upevňování znalostí a dovedností přizpůsobovat individuálním a aktuálním potřebám žáka (tempo, rozsah, časová dotace).

Forma zadávání úkolů

1) Ústně, opakovaně dle potřeby, z blízkosti, s upozorněním, vyžádáním očního kontaktu.

2) Fázování pokynu.

3) Ověření pochopení zadaného úkolu.

\section{Pedagogické postupy}

1) Respektovat individuální tempo.

2) Stř́idat metody a formy práce.

3) Zařazovat relaxační techniky a chvilky.

4) Využívat kompenzační mechanismy.

5) Využívat dle situace a potřeby multisenzoriální přístup (pomůcky) či jen monosenzoriální přístup (při stimulaci).

6) Vhodně reagovat při nesrozumitelném verbálním projevu dítěte.

\section{Spolupráce s rodiči}

1) Jedenkrát za 14 dnů konzultace $\mathrm{s} T U$, jedenkrát za tři měsíce společně s ŘŠ a pracovníkem SPC.

2) V rámci konzultačních třídních schůzek.

3) Pravidelné, systematické a důsledné vedení stimulace v domácích podmínkách, zodpovědnost rodičů za realizaci terapie v domácím prostředí.

4) Zabezpečení pravidelného režimu v domácím prostředí. 
5) Zajištění předávání informací mezi odborníky pečujícími o chlapce.

\section{Podíl žáka}

1) Zvyšování spoluzodpovědnosti.

\section{Reedukace a stimulace}

1) Zaměření dle závěrů a doporučení SPC.

2) Pravidelný záznam o průběhu stimulace.

\begin{tabular}{l|l} 
Oblast & Motorika \\
\hline
\end{tabular}

- rozvoj jemné motoriky, uvolňovací cvičení

- jednotahovky

- zaměřenost oka a ruky spojené s grafomotorikou

\section{Oblast}

\section{Sluchové vnímání}

- rytmizace

- analýza slova (vyvozování první hlásky)

- sluchová diferenciace - určování odlišnosti dvou podobných tónů

Oblast

\section{Zrakové vnímání}

- zraková diferenciace

- zraková pamět 
Determinanty inkluzivního vzdělávání dětís ADHD

\begin{tabular}{|l|l|}
\hline Oblast & \multicolumn{2}{|c|}{ Reč (dle plánu logopeda) } \\
\hline - rozvoj slovní zásoby \\
- podpora prosociální komunikace \\
- výbavnost slov - rozvoj vyprávění \\
\hline
\end{tabular}

Oblast

Pracovní návyky, chování

- dodržovat pravidla v MŠ

- dodržování hygienických návyků

- přijímat úkol a dokončit úkol

- dodržet pořadí činností

- posilování sociálních dovedností

- prodlužování délky soustředění a kvality soustředění 


\section{Závěr}

Děti s ADHD si osvojují sociální normy obtížněji ve srovnání s intaktními vrstevníky především z důvodu převažující impulzivity, neklidu, nesoustředěnosti. Jejich jedním z hlavních problémů bývá snížená schopnost až neschopnost dodržovat jakákoliv pravidla, ačkoliv jsou s nimi obeznámeny. Dokonce mohou být přesvědčeny o jejich důležitosti. Bývají často tak impulzivní a zbrklé, že u nich nelze hovořit o významnějším vlivu autoregulace na korekci jejich projevu.

Přijímání a úroveň zvládnutí nových sociálních rolí s nástupem do školy souvisí i u těchto dětí s vývojem jejich sebepojetí a sebehodnocení. To bývá v rámci obecného vývojového trendu závislé na hodnocení a postoji dospělých. V sebehodnocení dítěte se odráží i citový vztah dospělých včetně učitelů k osobě dítěte a význam, který pro něj mají. Pokud je tento vztah např. ze strany učitele $\mathrm{k}$ dítěti deformován, tzn., že například je dítě nekriticky nadhodnocováno či naopak extrémně kritizováno, výsledkem se stává méně adekvátní hodnocení a s ním související narušený postoj k dítěti s ADHD ve srovnání s postojem $\mathrm{k}$ běžné populaci. Lze tedy říci, že mnohé změny osobnostního vývoje hyperaktivního dítěte mohou být a jsou důsledkem negativních reakcí okolí, které vyvolává jejich impulzivita. Často bývají negativně posuzovány i z hlediska rozumového.

Můžeme říci, že hyperaktivní žák vyvolává napětí ve všech lidech, kteří s ním musí být v každodenním kontaktu po delší dobu. Bohužel mnohdy působí na okolí nepříjemně svými nevyzpytatelnými reakcemi. Pro učitele ve škole, ale i pro spolužáky bývá těžce akceptovatelný, protože ruší a učitele psychicky vyčerpává. Proto je nezbytné, aby učitelé byli stále co nejlépe o podstatě poruchy informováni, měli 
možnost si vyměňovat zkušenosti o metodách práce s těmito dětmi, vhodné by byly i supervize.

Úroveň znalostí českých učitelů o poruše ADHD se spolehlivostí, se kterou lze zevšeobecnit výsledky analýzy znalostí vzorku 240 pedagogů, odpovídá úrovni znalostí učitelů z jiných zemí - USA (Sciutto 2000a), USA (Small 2003), Austrálie (Kos 2004), JAR (Kleynhans 2005), Španělsko (Jarque Fernández 2007), Vietnam (Graeper 2008), USA (Guerra 2012), Saudskoarabské království (Alkahtani 2013), Thajské království (Muanprasart 2014).

Nejlépe si naši učitelé vedli v oblasti diagnostiky (relativní KADDS skór subškály Symptomy \& diagnostika =69,3\%), nižší znalosti se projevily v oblasti všeobecných teoretických znalostí o ADHD (relativní KADDS skór subškály V̌̌eobecně o $A D H D=48,1 \%$ ) a nejnižší výkon podali voblasti intervence (relativní KADDS skór subškály Intervence \& terapie $=41,8 \%$ ).

Výzkumem byly prokázány faktory, které u našeho respondentského vzorku významně souvisí se znalostmi o ADHD, s diagnostikou a intervencí či terapií u hyperaktivních žáků. Nejvyšší signifikance byla prokázána u faktorů: výše dosaženého vzdělání, pracovní zařazení a sebehodnocení vlastních znalostí o ADHD. Je potřebné, aby si vedoucí pedagogičtí pracovníci i sami pedagogové uvědomili, že právě tyto a možná také i další faktory mohou ovlivnit úroveň vzdělání a vzdělávání žáků a studentů s ADHD. Sherman, Rasmussen a Baydala (2006) ve shodě s námi se domnívají, že tak jako pro lékaře, psychiatra, klinického psychologa se objevují nové poznatky o způsobu léčby $\mathrm{ADHD}$ medikamenty a terapií, vedoucí k zlepšení školní úspěšnosti těchto žáků, tak názory učitelů, jejich zkušenosti, vzdělání či čas věnovaný těmto žákům může rovněž pozitivně jejich školní úspěšnost ovlivnit.

Prostor pro další zvyšování úrovně znalostí o poruše ADHD a zejména o metodách práce s žáky s ADHD a vlivu určitých faktorů, které mohou být nedílnou komponentou pro maximalizaci potenciálu těchto 
žáků ve školním prostředí, je obrovský. Zejména praktické využití získaných znalostí v samotném výchovně vzdělávacím procesu má stále významné rezervy a zasloužilo by si mnohem větší celospolečenskou pozornost. I přes určitá omezení daná výběrem vzorku respondentů spatřjeme význam provedeného průzkumu zejména $\mathrm{v}$ tom, že zaměřuje pozornost na oblast znalostí učitelů o ADHD nejen po stránce teoretické, ale i praktické. Je to první orientační průzkum a srovnání znalostí učitelů o poruše ADHD s učiteli z ostatních zemí. Potěšující je, že za ostatními zeměmi nezaostáváme. Je na pedagogických fakultách, vedení jednotlivých škol i na samotných učitelích, aby se aktivně podíleli na zvyšování úrovně znalostí o poruše ADHD, zejména na praktickém uvádění získaných poznatků do praxe. Další výzkumy by bylo třeba zaměřit na zkoumání příčin, proč učitelé své teoretické poznatky nedostatečně uplatňují v samotném výchovně vzdělávacím procesu. Trendem českého školství je integrace dětí se speciálními vzdělávacími potřebami, tedy i žáků s ADHD, do běžných základních škol. Bez dostatečných znalostí učitelů o ADHD a jejich následného uplatnění $\mathrm{v}$ praxi je úspěšná integrace těchto žáků významně ohrožena, alespoň do té míry, že nemají šanci v hlavním vzdělávacím proudu uplatnit své skutečné dispozice. Užitečné strategie na podporu rozvoje pozitivní inkluzivní praxe pro žáky s ADHD ve školním prostředí musí pro učitele znamenat naučit se změnit pohled na vnímání obsahu termínu těchto poruch (Cooper 2005 cit. dle Humphrey 2009). 


\section{Seznam grafů}

Graf 1: Věkové rozdělení respondentů.......................................... 119

Graf 2: Délka pedagogické praxe .............................................. 121

Graf 3: Nejvyššśi dosažené vzdělání ............................................ 122

Graf 4: Pracovní zařazení respondenta ve škole ............................. 123

Graf 5: Typ školy, na které respondent pracuje ............................ 124

Graf 6: Počet dětí s ADHD, se kterým se respondent setkal .......... 125

Graf 7: Jedinec s ADHD mezi příbuznými / přáteli ....................... 126

Graf 8: Sebehodnocení vlastních znalostí o ADHD ........................ 126

Graf 9: Didaktická forma získávání znalostí o ADHD .................... 127

Graf 10: Četnosti absolutních KADDS skórů - celá škála............... 129

Graf 11: Korelace KADDS × subškála Všeobecně o ADHD .............. 132

Graf 12: Korelace KADDS × subškála Symptomy \& diagnostika.... 132

Graf 13: Korelace KADDS × subškála Intervence \& terapie ............ 133

Graf 14: Korelace subškál Symptomy \& diagnostika × Intervence \& terapie 133

Graf 15: Relativní úspěšnost položek škály KADDS..................... 143

Graf 16: Relativní úspěšnost položek subškály V̌̌eobecně o ADHD 146

Graf 17: Relativní úspěšnost položek subškály Symptomy \& diagnostika 146 Graf 18: Relativní úspěšnost položek subškály Intervence \& terapie. 147

\section{Seznam obrázků}

Obrázek 1: Ochranný obal SuperShell .............................................. 93

Obrázek 2: Hodnocení průběhu čtyř vyučovacích hodin pomocí smajlíků, první varianta

Obrázek 3: Hodnocení průběhu čtyř vyučovacích hodin pomocí smajlíků, druhá varianta 


\section{Seznam tabulek}

Tabulka 1: Typické příznaky ADHD v dětství ................................ 21

Tabulka 2: Typické příznaky ADHD v dospělosti (včetně dospívání) .. 21

Tabulka 3: Duševní poruchy a poruchy chování dle MKN-10 .......... 50

Tabulka 4: Systém vzdělávacích cílů........................................... 66

Tabulka 5: Rozdělení položek škály KADDS do subškál ................ 109

Tabulka 6: Genderové rozdělení respondentů................................ 118

Tabulka 7: Věkové rozdělení respondentů ................................... 119

Tabulka 8: Délka pedagogické praxe respondentů ........................ 120

Tabulka 9: Pracovní zařazení respondenta ve škole ....................... 123

Tabulka 10: Celkový absolutní a relat. KADDS skór - celá škála .. 128

Tabulka 11: Abs. a rel. KADDS skór - subškála Všeobecně o ADHD ....129

Tabulka 12: Abs. a rel. KADDS skór - subškála Symptomy \& diagnostika . 130

Tabulka 13: Abs. a rel. KADDS skór - subškála Intervence \& terapie . 130

Tabulka 14: KADDS - vzájemné porovnání subškál a celé škály ... 130

Tabulka 15: Reliabilita dat celk. KADDS skóru a skórů jednotl. subškál. 134 Tabulka 16: Vzdělání respondenta × celkový relativní KADDS skór 136 Tabulka 17: Pracovní zařazení respondenta × celk. rel. KADDS skór 137 Tabulka 18: Typ školy, na které respondent pracuje × celk. rel. KADDS skór 138 Tabulka 19: Zkušenosti s žáky s ADHD × celk. rel. KADDS skór... 139 Tabulka 20: Jedinec s ADHD mezi příb. nebo přát. × celk. rel. KADDS skór 139 Tabulka 21: Sebehodnocení vlast. znalostí o ADHD × celk. rel. KADDS skór 140 Tabulka 22: Potřeba sebevzdělávání × celkový relativní KADDS skór 141 Tabulka 23: Úspěšnost položek škály KADDS.............................. 144

Tabulka 24: Celkový relativní KADDS - mezinárodní srovnání..... 150 Tabulka 25: Úspěšnost položek škály KADDS - mezinár. srovnání... 152 Tabulka 26: Př́íklad denního rozvrhu .......................................... 188

Tabulka 27: Př́íklad učebního plánu pro 2. stupeň ZŠ ................... 188 


\section{O autorech}

\section{Mgr. Vlastimil CHYTRÝ, Ph.D.}

Akademický pracovník Pedagogické fakulty Univerzity J. E. Purkyně v Ústí nad Labem, kde se věnuje př́ípravě budoucích učitelů. Kromě problematiky matematického a logického myšlení žáků základních a středních škol se také zajímá o matematické a logické hry potažmo výukové metody, $\mathrm{s}$ čímž je také velice úzce propojena jeho publikační činnost ve formě článků a monografií. Dále se profiluje v oboru statistiky. Je autorem studijních materiálů, pracovních sešitů a skript zaměřených na výukové metody ve vyučování matematice a na didaktiku geometrie. Spolupracuje na významných projektech, mezi které je možné zařadit: EMPAS - Engaging Migrants Parents and Children - Raising achievement in Children's Centres and Schools z programu Evropské komise PROGRESS, Otevřená univerzita, otevřená věda; To je věda, seznamte se - podpora systematické práce s žáky a studenty v oblasti vědy, výzkumu a vývoje; Nadání je třeba rozvíjet aj. Dlouhodobě spolupracuje s Fakultou prírodných vied Univerzity Konštantína Filozofa v Nitře.

\section{PhDr. et. Mgr. Zdeňka MICHALOVÁ, Ph.D.}

Svou práci s dětmi se zdravotním postižením, znevýhodněním a oslabením zahájila po ukončení vysokoškolského studia v roce 1984 jako učitelka, postupně jako poradenský pracovník, a to na pozici speciálního pedagoga a později i psychologa. Ve své praxi se orientuje převážně na osoby s poruchami učení a chování a s mentálním postižením. Od roku 1997 se zároveň profesně věnuje přípravě studentů především v oboru speciální pedagogiky, aktuálně působí na Pedagogické fakultě Univerzity J. E. Purkyně v Ústí nad Labem. Je autorkou mnoha reedukačně a preventivně orientovaných publikací, pracovních sešitů a stimulačního programu pro děti s percepčněmotorickými oslabeními, obtížemi ve čtení, psaní a v matematice. Články a monografie určené pro studující, odbornou a laickou veřejnost jsou ve velké míře propojeny s výzkumnou prací orientovanou na sociální aspekty poruch učení a chování a podporu úspěšné edukace jejich nositelů. 


\section{RNDr. Pavel PEŠAT, Ph.D.}

Akademický pracovník Pedagogické fakulty Univerzity J. E. Purkyně v Ústí nad Labem. Zaměřuje se na problematiku rizikového chování uživatelů v prostředí Internetu, na využívání digitálních technologií ve vzdělávání žáků se speciálními vzdělávacími potřebami a na obecné problémy využívání digitálních technologií ve vzdělávání. V těchto oborech je autorem více než 60 původních prací. Na $\mathrm{PF}$ UJEP se věnuje přípravě budoucích učitelů, speciálních pedagogů, sociálních pedagogů a sociálních pracovníků. Je členem redakce časopisu Speciální pedagogika, členem expertního týmu pro oborovou didaktiku informatiky a ICT panelu při Národním ústavu pro vzdělávání, dlouhodobým členem výkonného výboru Jednoty školských informatiků (Praha) a pracovní skupiny pro fyziku při Société Européenne pour la Formation des Ingénieurs (Brusel). Dlouhodobě spolupracuje s Pedagogickou fakultou Alabamské university (Birmingham, USA), institutem IFRASS (Toulouse, Francie), Centrem mikropočítačových aplikací Amsterodamské univerzity (Amsterodam, Nizozemsko) a Sociologickým institutem Rzeszowské univerzity (Polsko). Hostuje na Linného univerzitě ve Švédsku (Växjö, Kalmar).

\section{doc. PhDr. PaedDr. Ilona PEŠATOVÁ, Ph.D.}

Zaměřuje se na vzdělávání dětí se speciálními vzdělávacími potřebami. Pracovala jako učitelka a vychovatelka v dětském diagnostickém ústavu, ve výchovném ústavu a ve stacionáři pro děti s těžkými kombinovanými vadami. Od roku 1992 se věnuje také poradenské profesi na pozici speciálního pedagoga. Vedla řadu výzkumných i pedagogických projektů, je autorkou mnoha článků, monografií a metodických publikací zaměřených na edukaci jedinců se speciálními vzdělávacími potřebami, zejména s poruchami učení a chování. Je členkou vědeckých, příp. redakčních rad časopisů Kwartalnik Edukacyjny (Polsko), Dobroczynność, Filantropia $i$ Praca Socjalna (Polsko), Špeciálny pedagóg: časopis pre špeciálnopedagogickú teóriu a prax (Slovensko) a Fórum sociální práce (ČR). Dlouhodobě se věnuje také vysokoškolské přípravě speciálních pedagogů, učitelů a sociálních pracovníků. Na Univerzitě Jana Evangelisty Purkyně v Ústí nad Labem je garantkou studijního programu speciální pedagogika. V zahraničí dlouhodobě spolupracuje s Pedagogickou fakultou Alabamské university (Birmingham, USA), s Linného univerzitou ve Švédsku (Växjö, Kalmar) a se Sociologickým institutem Rzeszowské univerzity (Polsko). 


\section{Rejstř́ik}

\section{A}

ADHD. viz porucha pozornosti

s hyperaktivitou

projevy, 13, 18, 19, 24, 29, 64, 82,

$88,93,179$

subtypy, 7, 13

výskyt, 17, 32, 148

\section{C}

cíl

intervence, 72

osobnostní a sociální výchovy, 75

rámcový, 66

terapie, 68

vzdělávací, $66,84,85$

D

determinanty, 9, 105

diagnostika, 8, 17, 22, 26, 103, 208

pedagogická, 27

dysfunkce, 43

dysgrafie, 34, 39, 45, 47, 90, 158, 162

dyskalkulie, 39, 46, 90

dyslexie, 34, 39, 40, 41, 43, 47, 89,

155

dysmuzie, 39,48

dysortografie, 34, 39, 43, 44, 90, 158, 162

dyspinxie, 39, 47, 48

dyspraxie, 34, 39, 48, 160

E

EEG. viz elektroencefalograf

elektroencefalograf, 25

\section{$\mathbf{F}$}

faktor, 61, 106

lidský, 169 pozitivní, 86

rizikový, $26,85,89$

funkce, 17

\section{H}

hyperaktivita, 11, 13, 14, 15, 19, 21, $25,26,29,31,34,35,36,38,43$, $82,89,93,166,183,184,207$ hypoaktivita, 64

I

ICT. viz technologie digitální impulzivita, 13, 14, 15, 18, 20, 21, 22, $23,33,36,38,64,72,180,207$ internet, 81, 88, 91

IVP. viz plán vzdělávací IVýP. viz plán výchovný

K

KADDS, 9, 107, 108

komparace zahraniční, 149

reliabilita, 110, 133

skór absolutní, 108, 116, 128

skór relativní, 108, 116

stabilita, 111

subškály, 108, 109, 111, 116, 129

úspěšnost položek, 117, 142

kognitivní

deficit, 13, 37, 40

funkce, 13,88

model, 12

problémy, 59

reprezentace, 62

komorbidita, 18, 89

kompetence, 60

digitální, 90

klíčové, 66, 67

učitele, 100 
$\mathbf{L}$

léčba, 37, 68

\section{M}

model

biochemický, 12

kognitivní, 12

neurobiologický, 12

motorika, 18, 44, 45, 87, 160, 205

$\mathbf{N}$

nepozornost, $15,16,19,21,32,64$,

82,160

\section{$\mathbf{O}$}

období

adolescence, 35

batolecí, 30

dospělosti, 155

dospívání, 8

kojenecké, 29

novorozenecké, 29

prenatální, 26

předškolního věku, 32

školního věku, 33

vývojové, 29

opatření

podpůrná, 7, 103, 159, 177, 193, 196, 198

výchovná, 185, 200

\section{$\mathbf{P}$}

pedagog, 8, 51, 66, 81, 85, 95, 96

plán

úkolů, 49

výchovně vzdělávací, 189, 190, 200

výchovný, 189, 192, 193, 194, 196, 198

vzdělávací, 95, 155, 163, 176, 177

počítač, $37,81,82,84,87$ porucha

afektivní, 18

fobická, 18

chování, 7, 8, 18, 35

opozičního vzdoru, 18

pozornosti, $7,13,38$

pozornosti s hyperaktivitou, 7,11 ,

$12,15,18,82$

spánku, 18

učení, $7,13,14,18,24,39,40,41$, 50, 86, 89, 90, 95

úzkostná, 18

vývojová, 8, 39, 41, 50

pozornost, 22, 23, 64, 82, 157, 182

narušená, 14, 155

porucha, 7

program

počítačový, $81,84,85,86,89$

statistický, 110, 115

studijní, 97

terapeutický, 37

vzdělávací, 37, 60, 65, 200

\section{$\mathbf{R}$}

rozvoj, 89, 201, 206

kompetencí, 78

morální, 73

osobnosti, 60, 62, 70

osobnostní, 72

profesní, 91

sociální, 73

RVP. viz program vzdělávací

\section{$\mathbf{S}$}

Sciutto, 9, 105, 120, 208

speciální

pedagog, 51, 52, 122

pedagogika, 97

škola, 153, 175

vzdělávací potřeby, $8,63,77,84$,

85, 90, 97, 162, 209 
strategie

pedagogická, 96

výuková, 78

vzdělávací, 84, 153

SVP. viz speciální vzdělávací potřeby

$\mathbf{T}$

technologie

asistivní, 83, 85

digitální, 81, 82, 83, 89, 90

terapie, $22,57,68$

pobídková, 88

$\mathbf{U}$

učitel. viz pedagog

\section{V}

výchova

osobnostní a sociální, 60

vzdělávání, 7, 65, 96, 153, 167

inkluzivní, 9, 92, 95, 102, 105, 106, 135

$\mathbf{Z}$

zásady

etické, 51

metodické, 91

výchovné, 68, 76 


\section{Seznam použité literatury}

1) ALKAHTANI, K. D. F., 2013. Teachers' Knowledge and Misconceptions of Attention Deficit/Hyperactivity Disorder. Psychology. [online]. Vol. 4, No. 12. [vid. 2015-04-15], s. 963-969. ISSN 1940-4476. Dostupné z: http://dx.doi.org/10.4236/psych.2013.412139.

2) AMERICAN PSYCHIATRIC ASSOCIATION, 2015. Diagnostic and Statistical Manual of Mental Disorders, Fifth Edition (DSM-5). [online], [vid. 2015-07-25]. Dostupné z:

http://www.psychiatry.org/psychiatrists/practice/dsm. V textu uváděno pod zkratkou: DSM-5.

3) ASHERSON, P., KUNTSI, J., TAYLOR, E., 2005. Unravelling the complexity of attention-deficit/hyperactivity disorder: A behavioral genomic approach. British Journal of Psychiatry, 187, s. 103-105. ISSN 0007-1250.

4) BANDURA, A., et al., 2003. Role of Affective Self-Regulatory Efficacy in Diverse Spheres of Psychosocial Functioning. Child Development, Vol. 74, No. 3, s. 769-782.

5) BANERJEE, S., 2013. Attention Deficit Hyperactivity Disorder in Children and Adolescents. INTech 2013. 326 s. ISBN 978-953-511086-6. [online] [vid. 2014-25-06]. Dostupné z:

http://www.intechopen.com/books/attention-deficit-hyperactivitydisorder-in-children-and-adolescents

6) BARKLEY R. A., 2006. Attention-Deficit Hyperactivity Disorder. A Handbook for Diagnosis and Treatment, $3^{\text {rd }}$ edition. New York: Guilford Press. ISBN 1-59385-210-X.

7) BARKLEY R. A., 2009. Deficient Emotional Self-Regulation: A Core Component of Attention-Deficit Hyperactivity Disorder. Journal ADHD and Related Disorder. s. 5-37.

8) BARLOW, D. H., CHORPITA, B. F., TUROVSKY, J., 1996. Fear, panic, anxiety and disorders of emotions. In: D. A. Hope (Eds.). Nebraska Symposium on Motivation: Perspectives on anxiety, panic, and fear, s. 251-328. US, Lincoln: University of Nebraska Press. 
9) BARRET, P. M., OLLENDICK, T. H. (eds.), 2007. Handbook of interventions that work with children and adolescents: prevention and treatment. John Wiley \& Sons Ltd. 555 s. [online], [vid. 2015-07-07]. ISBN 9780470753385. DOI: 10.1002/9780470753385. Dostupné z: http://onlinelibrary.wiley.com/book/10.1002/9780470753385.

10) BARTOŇOVÁ, M., 2006. Kapitoly ze specifických poruch učení I. Dotisk 1. vyd. Brno: MU. ISBN 80-210-3613-3.

11) BHANDARY, A. N., a kol., 1997. Pharmacotherapy in adults with ADHD. Psychiatric Annals, 27, 8, p. 545-555. ISSN 0048-5713.

12) BROOKS, R. B., 2001. Fostering Motivation, Hope and Resilience in Children with Learning Disorders. Annals of Dyslexia, 51, s. 9-20. ISSN 0736-9387.

13) BŘICHÁČEK, V., 2003. Mezigenerační přínos výchovných stylů. Speciální pedagogika, roč. 13, č. 4, s. 270-273. ISSN 1211-2720. Dostupné z: http://dspace.specpeda.cz/bitstream/handle/0/508/270273.pdf.

14) BUSSING, R., SCHOENBER, N. E., ROGERS, K., ZIMA, B. T., ANGUS, S., 1998. Explanatory models of ADHD: Do they differ by ethnicity, child gender, or treatment status? Journal of Emotional and Behavioral Disorders. 6, s. 233-242. ISSN 1063-4266.

15) CAHOVÁ, P., PEJČOCHOVÁ, J., OŠLEJŠKOVÁ, H., 2010. Hyperkinetická porucha/ADHD v dospívání a dospělosti: diagnostika, klinický obraz a komorbidity. Neurologie pro praxi [online], roč. 11, č. 6, s. 373-377. [vid. 2014-08-07]. ISSN 1803-5280. Dostupné z: http://www.neurologiepropraxi.cz/pdfs/neu/2010/06/04.pdf

16) CANGELOSI, J. S., 1994. Strategie řizeni třidy: jak ziskat a udržet spolupráci žáků při výuce. 1. vyd. Praha: Portál. ISBN 80-7178-014-6.

17) CARLSON, C. L. et al, 2002. Parent-, Teacher-, and Self-Rated Motivational Styles in ADHD Subtypes. Journal of Learning Disabilities. Vol. 35, No. 2. s. 104-113. [online]. [vid. 2015-06-15], Dostupný z: doi:10.1177/002221940203500202

18) CARTER, CH. R., 2014. Ditě s ADHD a ADD doma i ve škole. 1. vyd. Praha: Portál, 2014. 120 s. ISBN 978-80-262-0621-7. 
19) CARVER, C. S., SCHEIER, M. F., 2002. Optimism. In: SNYDER, C. R., LOPEZ, S. J. (eds.) Handbook of Positive Psychology. s. 231-243. US, New York: Oxford University Press. ISBN 0-19-513533-4.

20) COMINGS, D. E., CHEN, T. J., BLUM, K., MENGUCCI, J. F., BLUM, S. H., \& MESHKIN, B. 2005. Neurogenetic interactions and aberrant behavioral co-morbidity of attention deficit hyperactivity disorder (ADHD): dispelling myths. Theoretical Biology \& Medical Modelling, Vol. 2, No. 50. http://doi.org/10.1186/1742-4682-2-50 Dostupné z: http://www.ncbi.nlm.nih.gov/pmc/articles/PMC1352384/pdf/1742-46822-50.pdf

21) CUBILlO, A., HALARI, R., SMITH, A., TAYLOR, E., RUBIA, K., 2012. A review of fronto-striatal and fronto-cortical brain abnormalities in children and adults with Attention Deficit Hyperactivity Disorder (ADHD) and new evidence for dysfunction in adults with ADHD during motivation and attention. Cortex, Vol. 48, No. 2, s. 194-215. ISSN 0010-9452.

22) ČÁP, J., MAREŠ, J., 2001. Psychologie pro učitele. 1. vyd. Praha: Portál. ISBN 978-80-7178-463-X.

23) ČERNÁ, M., et al., 1999. Lehké mozkové dysfunkce. 3. vyd. Praha: UK. ISBN 80-7184-880-8.

24) ČESKÝ STATISTICKÝ ÚŘAD, ČSÚ 2013. Zaostřeno na ženy a muže 2014. Věková struktura učitelů regionálního školství bez řídicích pracovníků - ženy a muži v roce 2013. [online]. [vid. 2015-04-18], Dostupný z: https://www.czso.cz/documents/10180/25704419/3000023306.pdf.

25) ČESKÝ STATISTICKÝ ÚŘAD, ČSÚ 2014. Zaostřeno na ženy a muže 2014. Učitelé na jednotlivých typech a druzích škol podle pohlaví. [online]. [vid. 2015-04-18], Dostupný z: https://www.czso.cz/documents/10180/25704419/3000023302.pdf.

26) DANIELS, L., WIENER, J., 2002. Teachers' attitudes toward Attention Deficit/Hyperactivity Disorder (ADHD): Effects on student self-concept. Poster, Biennial Meeting of the International Society for the Study of Behavioral Development, August 1-4, Ottawa, ON. 
27) DEINER, P. L., 2010. Inclusive Early Childhood Education. 5. ed. Canada: Wadsworth Cengage Learning. Canada: Wadsworth Cengage Learning. ISBN 978-1-4390-4666-1.

28) DIENsBIER, R. A., ZILLIG, L. M., 2002. Thoughness. In C. R. SNYDER, S. J. LOPEZ (eds.). Handbook of Positive Psychology. s 515-527. US, New York: Oxford University Press. ISBN 0-19513533-4.

29) DOMANJA, J., 2014. Výuka (základů) informatiky na vysokých školách v ČR. [online]. [cit. 2015-06-25]. Praha. Bakalářská práce. Vysoká škola ekonomická v Praze. Vedoucí práce Václav Řezníček. Dostupné z: <http://theses.cz/id/jzaocd/>.

30) DRTÍLKOVÁ, I., 2007. Hyperaktivní dítě: vše, co potřebujete vědět o ditěti s hyperkinetickou poruchou (ADHD). 2. vyd., Praha: Galén, 87 s. ISBN 978-80-7262-447-8.

31) DUPAUL, G., J., et al., 2012. Comorbidity of LD and ADHD: Implications of DSM-5 for Assessment and Treatment. Journal of Learning Disabilities. Vol. 46, No. 1. s. 43-51. [online]. [vid. 2015-0418], Dostupný z: doi:10.1177/0022219412464351.

32) EDWARDS, G., et al., 2001. Parent-Adolescent conflict in teenagers with ADHD and ODD. Journal of Abnormal Child Psychology. Vol. 29, No. 6, s. 557-572. ISSN 0091-0627.

33) EGELAND, J., UELAND, T., JOHANSEN, S., 2011. Central Processing Energetic Factors Mediate Impaired Motor Control in ADHD Combined Subtype But Not in ADHD Inattentive Subtype. Journal of Learning Disabilities. Vol. 45, No. 4. s. 361-370. [online]. [vid. 2015-06-15], Dostupný z: doi:10.1177/0022219411407922.

34) FONTANA, D., 2010. Psychologie ve školní praxi. 3. vyd. Praha: Portál. 383 s. ISBN 978-80-7367-725-1.

35) GARAGOUNI-AREOU, F., SOLOMONIDOU, C., 2004. Towards the Design of Educational Environments Suitable to the Needs of Pupils with Attention Deficit Hyperactivity Disorder (ADHD) Symptoms. In L. Cantoni \& C. McLoughlin (Eds.), Proceedings of EdMedia: World Conference on Educational Media and Technology 2004. s 4446-4451. Association for the Advancement of Computing in Education (AACE). 
36) GAUB, M., CARLSON, C. L., 1997. Gender differences in ADHD. A meta-analysis of analysis and critical review. Journal of the American Academy of Child and Adolescent Psychiatry. Vol. 36, No. 2, s. 1036-1045. ISSN 0890-8567.

37) GERSHON, J., 2002. A meta-analytic review of gender differnces in ADHD. Journal of Attention Disorder. 5 (3), pp. 143-154. ISSN 10870547 .

38) GILLERNOVÁ, I., 2003. Sociální vztahy ve škole a profesní dovednosti učitele. In: M. SVOBODA, P. HUMPOLÍČEK, J. HUMPOLÍČKOVÁ (eds.) Sociální procesy a osobnost: sborník př́spěvků z 6. ročníku konference 2003 [CD]. Brno: Masarykova Univerzita. Filozofická fakulta. Psychologický ústav, 2003, s. 97-106. ISBN 80-86633-09-8.

39) GOETZ, M., UHLÍKOVÁ, P., 2009. ADHD porucha pozornosti s hyperaktivitou. 1. vyd. Praha: Galén. 160 s. ISBN 978-80-7262-630-4.

40) GRACZYK, P. A., ATKINS, M. S., JACKSON, M. M., LETENDRE, J. A., KIM-COHEN, J., BAUMANN, B. L., McCOY, J., 2005. Urban educators' perceptions of interventions for students with Attention Deficit/ Hyperactivity Disorder: A preliminary investigation. Behavioral Disorders. Vol. 30, s. 95-104. ISSN 0198-7429.

41) GRAEPER, K. D., BARKER, K. A., TERJESEN, M. D., 2008. Knowledge of ADHD Among Vietnamese and American Teachers. Collaborative Research Journal of School Psychology [online]. 2008 [vid. 2009-01-30], s. 18-22. ISSN 1696-2097.

42) GREENE, R. W., 1995. Students with ADHD in school classrooms: Teacher factors related to compatibility, assessment, and intervention. School Psychology Review. 24, s. 81-93. ISSN 0279-6015.

43) GREENE, R. W., et al., 2002. Psychiatric comorbidity, family dysfunction, and social impairment in referred youth with oppositional defiant disorder. American Journal of Psychiatry, Vol. 159, No. 7, s. 1214-1224. ISSN 0002-953X.

44) GROHNFELDT, M., 2004. Lehrbuch der Sprachheilpädagogik und Logopädie. Band 5. Bildung, Erziehung und Unterricht. Stuttgart: Kohlhammer Druckerei. 
45) GUERRA, F. R., BROWN, M. S., 2012. Teacher Knowledge of Attention Deficit Hyperactivity Disorder Among Middle School Students in South Texas. Research in Middle level Education On-line. [online]. Vol. 36, No. 3. [vid. 2015-04-15], pp. 1-7. ISSN 1940-4476. Dostupné z.:

https://www.amle.org/portals/0/pdf/rmle/rmle_vol36_no3.pdf.

46) HALlOWELL, E. M., 2005. Overloaded Circuits. Why Smart People Underperform. Harward Business Review. [online] [vid. 2015-19-06]. Dostupné z: http://www.integrityplus.com/eStore/WP/overload\%20circuitsR0501Ef2.pdf.

47) HAVLÍK, R., KOŤA, J., 2007. Sociologie výchovy a školy. 2. vyd. Praha: Portál. ISBN 978-80-7367-327-7-

48) HECKER, L., et al, 2002. Benefits of assistive reading software for students with attention disorders. Annals of Dyslexia, Vol. 52, s. 243272. ISSN 0736-9387.

49) HELUS, Z., 2004. Dítě v osobnostním pojetí: obrat $k$ dítěti jako výzva a úkol pro učitele i rodiče. 1. vyd. Praha: Portál. ISBN 978-80-7178-888-0.

50) HENDL, J., 2004. Přehled statistických metod zpracování dat. 2. opr. vyd. Praha: Portál. ISBN 978-80-7367-123-9.

51) HENDL J., 2012. Přehled statistických metod. Analýza a metaanalýza dat. Praha: Portál, 2012. 736 s. ISBN 978-80-262-0200-4.

52) HEPP, S. L., 2009. A psychometric examination of the knowledge of $A D H D$ scale. Diploma Thesis. Saskatoon: University of Saskatchewan.

53) HINSHAW, S. P., MELNICK, S. M., 1995. Peer relationships in children with attention-deficit hyperactivity disorder with and without comorbid aggression. Development and Psychopathology, Vol. 7, s. 627-647. ISSN 0954-5794.

54) HLAVOVÁ, J., ŠUKOVÁ, J., 2014. Doporučení pro práci se žáky $s A D D / A D H D$. PPP Liberec. [online] [vid. 2015-05-07]. Dostupné z: https://goo.gl/67YpjP.

55) HUMPHREY, N., 2009. Including students with attention-deficit/ hyperactivity disorder in mainstream schools. British Journal of Special Education, Vol. 36, No. 1, s. 19-25. ISSN 1467-8578. 
56) CHAN, P., RABINOWITZ, T., 2006. A cross-sectional analysis of video games and attention deficit hyperactivity disorder symptoms in adolescents. Annals of General Psychiatry Vol 5, No 16. [online] [vid. 2015-19-06]. Dostupné z: http://www.annals-generalpsychiatry.com/content/5/1/16.

57) CHRÁSKA, M., 2006. Metody pedagogického výzkumu. 1. vyd. Praha: Grada. ISBN 80-247-1369-1.

58) JARQUE FERNÁNDEZ, S., TÁRRAGA, R. M., MIRANDA, A. C., 2007. Conocimientos, concepciones erróneas y lagunas de los maestros sobre el trastorno por déficit de atención con hiperactividad. Psicothema. Vol. 19, No. 4, s. 585-590. ISSN 0214-9915.

59) JORDAN, L. SMITH, S. et all, 2004. Improving Content and Technology Skills in ADD/ADHD via a Web-Enhanced Course Teacher Education and Special Education. Journal of the Teacher Education Division of the Council for Exceptional Children Vol. 27: 231-239, [online] [vid. 2014-07-20]. Dostupné z: doi:10.1177/088840640402700303.

60) KALHOUST, Z.; OBST, O., 2002. Školní didaktika. Praha: Portál, 2002. ISBN 80-7178-253-X.

61) KEBLOVÁ, A., 1996. Integrované vzdělávání dětí se zrakovým postiženim. 1. vyd. Praha: Septima. ISBN 80-85801-65-5.

62) KENDALL, P. C., 1993. Cognitive-bahavioral therapies with youth: Guiding theory, current status and emerging developments. Journal of Consulting and Clinical Psychology, April 1993, Vol. 61, issue 2, s. 235-247. ISSN: 0022-006X.

63) KHER, N., MOLSTADT, S., DONAHUE, R., 2008. Using Humor in the College Classroom to Enhance Teaching Effectiveness in „Dread Courses“. College Student Journal. [online] [vid. 2012-19-08].

Dostupné z: http://jan.ucc.nau.edu/ slm/AdjCI/Startclass/Humor.html.

64) KLEYNHANS, S. E., 2005. Primary school teachers' knowledge and misperceptions of attention deficit/hyperactivity disorder (ADHD). Stellenbosch. 93 s. University of Stellenbosch. Vedoucí diplomové práce Mariechen Perold. 
65) KNOPF, H., SWICK, K. J., 2007. How Parents Feel About Thein Child's Teacher/School: Implications for Early Childhood Professionals. Early Childhood Education Professional. Vol. 34, No 4., s. 291-296. ISSN 1463-9491.

66) KOS, J. M., RICHDALE, A. L., JACKSON, M. S., 2004. Knowledge about Attention-Deficit/Hyperactivity Disorder: A Comparasion of Inservise and Preservice Teachers. Psychology in the Schools, Vol. 41, No. 5, s. 517-524. ISSN 0033-3085.

67) KOŠČ, L., 1987. Patopsychológia učenia a jej neuropsychologické základy. 1. vyd. Bratislava: SPN.

68) KRAJČÍ, P. 2014. Z problematiky elektronického vzdelávacieho prostredia žiakov s vývinovými poruchami učenia. In HARČARÍKOVÁ, T., KRAJČÍ, P. 2014. Poruchy učenia ako edukačný fenomén. Bratislava: Iris. s. 163-173. ISBN: 978-80-89726-15-8.

69) LEFCOURT, H. M., 2002. Humor. In: C. R. SNYDER, S. J. LOPEZ (eds.) Handbook of Positive Psychology. US, New York: Oxford University Press. s. 619-631. ISBN 0-19-513533-4.

70) LECHTA V., 1990. Logopedické repetitórium. 1. vyd. Bratislava: SPN. ISBN 80-08-00447-9.

71) LOPÚCHOVÁ, J., KRAJČÍ, P. 2014. Teória a výskum digitálnych a asistenčných technológií $v$ inkluzívnej špeciálnej pedagogike.

Ostrava: OU PdF, 2014. 200 s. ISBN 978-80-7464-675-1.

72) MALÁ, E., 2002. Hyperkinetické poruchy. [online]. [vid. 2012-21-09]. Pediatrie pro praxi, Dostupný z:

http://www.pediatriepropraxi.cz/pdfs/ped/2002/01/04.pdf. ISSN 12130494 .

73) MATĚJČEK, Z., 1993. Dyslexie specifické poruchy čtení. 2. upr. a rozš. vyd. Jinočany: H+H. ISBN 80-85467-56-9.

74) MERTIN, V., KUCHARSKÁ, A., 2007. Integrace žáků se specifickými poruchami učení - od stanovení kritérií $\mathrm{k}$ poskytování péče všem potřebným žákům. Pedagogicko-psychologické poradenství, 50, s. 6-16. 
75) MERTIN, V., KREJČOVÁ, L. (eds.), 2012. Pedagogická diagnostika pro učitele. 1. vyd. Praha: Wolters Kluwer Česká republika. ISBN 97880-7357-679-0.

76) MERTIN, V., KREJČOVÁ, L. et al., 2013. Problémy s chováním ve škole - jak na ně: individuální výchovný plán. Vyd. 1. Praha: Wolters Kluwer Česká republika. 198 s. ISBN 978-80-7478-026-4

77) MICHALOVÁ, Z., 2000. Postoj rodiny a školy $k$ problematice LMD SPU a jeho vliv na sebehodnocení dítěte. Disertační práce. Praha: Pedagogická fakulta UK.

78) MICHALOVÁ, Z., 2007. Sondy do problematiky specifických poruch chování. 1. vyd. Havlíčkův Brod: Tobiáš. ISBN 978-80-7311-075-X.

79) MICHALOVÁ, Z., 2011. ADD/ADHD v kontextu poruch chování. 1. vyd. Liberec: TU v Liberci. ISBN 978-80-7372-733-8.

80) MICHALOVÁ, Z., 2012. Předškolák s problémovým chováním: projevy, prevence a možnosti ovliunění. Vyd. 1. Praha: Portál, 2012. $162 \mathrm{~s}$. ISBN 9788026201823.

81) MICHALOVÁ, Z., PEŠATOVÁ, I., 2011. Specifické poruchy učení a chování v inkluzivním prostředí základní školy. 1. vyd. Liberec: TU v Liberci. ISBN 978-80-7372-815-1.

82) MICHALOVÁ, Z., PEŠATOVÁ, I., 2012. Hyperkinetické poruchy a jejich dopad na školní úspěšnost. Liberec: TU v Liberci, 2012. $88 \mathrm{~s}$. ISBN 978-80-7372-933-2.

83) MINISTERSTVO ŠKOLSTVÍ, MLÁDEŽE A TĚLOVÝCHOVY 2013. Metodické doporučení pro práci s Individuálním výchouným programem v rámci řešení rizikového chováni žákư, č.j. MSMT 43301/2013 ze dne 3. 12. 2013. . [online]. [vid. 2015-04-15]. Dostupný z: http://www.pppuo.cz/soubory/Metodicke\%20doporuceni\%20k\%20IVyP[ 1].pdf. V textu uváděno pod zkratkou: MSMT-43301/2013.

84) MLČÁK, Z., 1999. Psychická zátěž u dětí základní školy. 1. vyd. Ostrava: FF Ostravské univerzity. ISBN 80-7042-543-1.

85) MORGAN, W. P.; BROWN, D. R.; RAGLIN, J. S.; O'CONNOR, P. J.; ELLICKSON, K. A., 1987. Psychological Monitoring of Overtraining 
and Staleness. British. International Journal of Sport Medicine, Vol. 21, s. 107-114. ISSN 0172-4622.

86) MUANPRASART, P., ARUNYANART, W., 2014. Knowledge of Attention Deficit Hyperactivity Disorder and Its Associated Factors among Teachers in 3 Large Primary Schools in Phra Nakorn Sri Ayutthaya Province, Thailand. In: Journal of the Medical Association of Thailand, Vol. 97, Suppl. 2. ISSN: 2408-1981 [online] [vid. 2015-0507]. Dostupné z: http://researchpcm.com/data/journal97/S107S114_PMK5619.pdf.

87) MUNDEN, A., ARCELUS, J., 2008. Poruchy pozornosti a hyperaktivita. 3. vyd. Praha: Portál. ISBN 978-80-7367-430-4.

88) NEDVĚDOVÁ, B., 2013. Analýza připravenosti učitelů mateřských škol na práci s dětmi s hyperkinetickou poruchou. Ústí nad Labem, 2013. Bakalářská práce (Bc.). UNIVERZITA JANA EVANGELISTY PURKYNĚ V ÚSTÍ NAD LABEM. Pedagogická fakulta. Vedoucí práce Roman Kroufek.

89) NOVOTNÁ, M., KREMLIČKOVÁ, M., 1997. Kapitoly ze speciální pedagogiky pro učitele. 1. vyd. Praha: SPN. ISBN 80-95937-60-3.

90) PACLT, I., 2007. Hyperkinetická porucha a porucha chování. 1. vyd. Praha: Grada. ISBN 978-80-247-1426-4.

91) PARETTE, Jr, H. P., CROWLEY, E.P., WOJCIK, B.W., 2007. Reducing overload in students with learning and behavioral disorders: The role of assistive technology. In: Teaching Exceptional Children Plus, Vol. 4 No 1. Article 4. [online] [vid. 2015-19-06]. Dostupné z: http://files.eric.ed.gov/fulltext/EJ967467.pdf

92) PEROLD, M., LOUW, Ch., KLEYNHANS, S., 2010. Primary school teachers' knowledge and misperceptions of attention deficit hyperactivity disorder (ADHD). In: South African Journal of Education. Vol. 30. s. 457-473. . [online] [vid. 2015-19-06]. ISSN: 0256-0100 Dostupné z:

http://www.ajol.info/index.php/saje/article/download/60041/48299.

93) PEŠAT, P., VANĚK, V., 2012. Metoda P-Scales v hodnocení žáků se speciálními vzdělávacími potřebami. In ICT ve vzdělávání. Sborník 
konference 7.-8. 11. 2012, Olomouc. Univerzita Palackého v Olomouci: Olomouc, 2012. s. 137-151. ISBN 978-80-244-3362-2.

94) PEŠAT, P., 2015. e-Skills for Jobs ve vzdělávání na Univerzitě J. E. Purkyně. In: TRAJTEL, L., ed. DIDINFO 2015, Sbornik 21. ročníka národnej konferencie s medzinárodnou účastou. 15.-17. apríl 2015, Banská Bystrica. Univerzita Mateja Bela, Banská Bystrica, 2015. s. 123-129. ISBN 978-80-557-0852-2.

95) PEŠATOVÁ, I., 2003. Vybrané kapitoly $z$ etopedie. Klasifikace a diagnostika poruch chování. Liberec: TU v Liberci. 71 s. ISBN 807083-750-0.

96) PEŠATOVÁ, I., 2007. Sociálně patologické jevy u dětí školního věku. 1. vyd. Liberec: TUL. ISBN 978-90-7372-291-3.

97) PEŠATOVÁ, I., 2013. Hyperkinetické poruchy ve vztahu k poruchám chování. In: ČERVENKA, K., VOJTOVÁ, V. 2013. Východiska pro speciálněpedagogické intervence v etopedii. 1. Vyd. Brno: MU. s. 7-20. ISBN 978-80-210-6617-5.

98) PEŠOVÁ, I., ŠAMALÍK, M., 2006. Poradenská psychologie pro děti a mládež. 1. vyd. Praha: Grada. ISBN 978-80-247-1216-4.

99) PFIFFNER, L. J., BARKLEY, R. A., 1990. Educational placement and classroom management. In: R. A. BARKLEY (ed.) Attention-deficit hyperactivity disorder: A handbook for diagnosis and treatment. New York: Guilford Press. s. 498-539. ISBN 089862603X.

100) PILAŘOVÁ, M., KAVALE-PAZLAROVÁ, M., 1999. ADHD a ADD reflexe z odborné literatury 90. let. In: KUCHARSKÁ, A., ed. Specifické poruchy učení a chování: Sborník 1999. 1. vyd. Praha: Portál. ISBN 80-7178-294-7, ISSN 1211-670X.

101) POKORNÁ, V., 2001. Teorie a náprava vývojových poruch učení a chování. 3. vyd. Praha: Portál. ISBN 80-7178-570-9.

102) POWER, T. J., HESS, L. E., BENNETT, D. S., 1995. The acceptability of interventions for Attentiondeficit/ Hyperactivity Disorder among elementary and middle school teachers. Journal of Developmental and Behavioral Pediatrics Vol. 16, s. 238-243. ISSN 1536-7312. 
103) PRŮCHA, J., 2005. Moderní pedagogika. 3. vyd. Praha: Portál. ISBN 97-80-7367-047-X.

104) PRŮCHA, J., WALTEROVÁ, E., MAREŠ, J., 2005. Pedagogický slovník. 4. vyd. Praha: Portál. ISBN 978-80-7290-085-4.

105) RAMBOUSEK, V., a kol., 2013. Rozvoj informačně technologických kompetencí na základních školách. Vyd. 1. Praha: České vysoké učení technické v Praze. 351 s. ISBN 978-80-01-05407-9.

106) RAMSAY J.R., ROSTLIN A. L., 2008. Cognitive-Behavioral Therapy for Adult ADHD. An Integrative Psychosocial and Medical Approach. Routledge, 2008.

107) RIEFOVÁ, Sandra F., 2010. Nesoustředěné a neklidné dítě ve škole: praktické postupy pro vyučování a výchovu dětí s ADHD. 4. vyd. Praha: Portál. ISBN 978-80-7367-728-2.

108) RODRIGUEZ - ECHANDIA, E. L., GONZALES, A. S., CABRERA, R., FRACCHIA, L. N., 1998. A Further Analysis of Behavioral and Endocrine Effect of Unpredictable Chronic Stress. Physiology and Behavior. Vol. 43, No. 6, s. 789-795. ISSN 0031-9384.

109) ROGERS, C.R. 1998. Způsob bytí. Praha: Portál. 312 s. ISBN 80-7178233-5.

110) ROSEN, L., 2014. ADHD and Technology: Helping Our Children Reclaim Their Focus and Attention. [online]. [vid. 2015-07-09]. The Huffington Post - Blog. Dostupný z: http://www.huffingtonpost.com/drlarry-rosen/adhd-and-technology-helpi_b_6096168.html.

111) ŘÍČAN, P., KREJČÍŘOVÁ, O., aj., 1997. Dětská klinická psychologie. 3. vyd. Praha: Grada Publishing. ISBN 80-7169-512-2.

112) ŘÍČAN, P., KREJČÍŘOVÁ, O., aj., 2006. Dětská klinická psychologie. 4. přepr. a dopl. vyd. Praha: Grada Publishing. ISBN 978-80-2471049-5.

113) SCIUTTO, M. J., TERJESEN, M. D., BENDER FRANK, A. S., 2000a. Teachers' Knowledge and Misperceptions of AttentionDeficit/Hyperactivity Disorder. Psychology in the Schools, Vol. 35, No. 2, s. 115-122. ISSN 517-526. 


\section{Determinanty inkluzivniho vzděláváni dětís ADHD}

114) SCIUTTO, M. J., FELDHAMER, E., 2000b. Knowledge about Attention-Deficit/ Hyperactivity Disorder : KADDS. Test manual. [s.l.] : [s.n.] 23 s. Dostupné u autora: sciutto@muhlenberg.edu.

115) SCIUTTO, M. J., TERJESEN, M. D., 2004. Psychometric properties of the Knowledge of Attention Deficit Disorders Scale (KADDS).

Unpublished test development data.

116) SEDLÁK, J., 2006. Vytváření pozitivního školního klimatu: humor ve škole. Pedagogická orientace. 4, s. 69-73. ISSN 1211-4669.

117) SEXTON, Ch., C. et al., 2012. The Co-occurrence of Reading Disorder and ADHD: Epidemiology, Treatment, Psychosocial Impact, and Economic Burden. Journal of Learning Disabilities. Vol. 45, No. 6. s. 538-564. [online]. [vid. 2015-06-15], Dostupný z: doi:10.1177/0022219411407772.

118) SHERMAN, J., RASMUSSEN, C., BAYDALA, L., 2006. Thinking positively: How some characteristics of ADHD can be adaptive and accepted in the classroom. Childhood Education. Vol. 82, s. 196-200. ISSN 0009-4056.

119) SIJTSMA, K., 2009. On the use, the misuse, and the very limited usefulness of Cronbach's alpha. Psychometrika [online]. 2009, Vol. 74, No. 1, s. 107-120, ISSN 0033-3123 (tisk), ISSN 1860-0980 (online). DOI: 10.1007/s11336-008-9101-0. Dostupné z <http://www.ncbi.nlm.nih.gov/pmc/articles/PMC2792363/>.

120) SMALL, S., 2003. Attention-deficit/hyperactivity disorder: General education elementary school teachers' knowledge, training, and ratings of acceptabilty of interventions. Tampa, 2003. Doktorská práce (PhD). UNIVERSITY OF SOUTH FLORIDA. College of Education. [online] [vid. 2015-05-07]. Dostupné z:

http://scholarcommons.usf.edu/cgi/viewcontent.cgi?article=2478\&conte $\mathrm{xt}=\mathrm{etd}$

121) SOLOMONIDOU, C., GARAGOUNI-AREOU, F. \& ZAFIROPOULOU, M., 2004. Information and Communication Technologies (ICT) and Pupils with Attention Deficit Hyperactivity Disorder (ADHD) Symptoms: Do the Software and the Instruction Method Affect Their Behavior? Journal of Educational Multimedia and Hypermedia, Vol. 
13, No. 2, s. 109-128. Norfolk, VA: Association for the Advancement of Computing in Education (AACE). [online] [vid. 2015-05-07]. Dostupné z: http://www.editlib.org/p/12868.

122) SOROA, M., GOROSTIAGA, A., BALLUERKA, N., 2013. Review of Tools Used for Assessing Teachers' Level of Knowledge with Regards Attention Deficit Hyperactivity Disorder (ADHD). [online] [vid. 201505-07]. Dostupné z: http://www.intechopen.com/books/attentiondeficit-hyperactivity-disorder-in-children-and-adolescents/review-oftools-used-for-assessing-teachers-level-of-knowledge-with-regardsattention-deficit-hypera

123) SPILKOVÁ, V., 2005. Proměny primárního vzdělávání v ČR. 1. vyd. Praha: Portál. ISBN 978-90-7178-942-9.

124) ŠTURMA, J. (1997). Specifické poruchy učení a chování. In: P. Říčan, D. Krejčířrová. Dětská klinická psychologie. 3. vyd. Praha: Grada. (s. 127-148). ISBN 80-7169-512-2.

125) THAPAR, A., HOLMES, J., POULTON, K., HARRINGTON, R., 1999. Genetic basis of attention deficit and hyperacitivity. British Journal Psychiatry, Vol. 174, p. 105-111. ISSN 0007-1250.

126) THEINER, P., 2012. ADHD od dětství do dospělosti. Neurologie pro praxi [online], roč. 13 č. 4, s. 148-151. [vid. 2014-08-07]. ISSN 18035280. Dostupné z:

http://www.psychiatriepropraxi.cz/pdfs/psy/2012/04/02.pdf

127) TRAIN, A., 1997. Specifické poruchy chování a pozornosti: jak jednat s velmi neklidnými dětmi. Praha: Portál. ISBN: 80-7178-131-2.

128) VÁGNEROVÁ, M., VALENTOVÁ, L., 1991. Psychický vývoj dítěte a jeho variabilita. 1. vyd. Praha: Univerzita Karlova. ISBN 80-7066-384-7.

129) VÁGNEROVÁ, M., 2004. Psychopatologie pro pomáhající profese. Praha: Portál. 872 s. ISBN 80-7178-802-3.

130) VÁGNEROVÁ, M., 2008. Psychologie problémových dětí a mládeže. 1. vyd. Liberec: Technická univerzita. ISBN 978-80-7083-378-5.

131) VALENTA, J., 2006. Osobnostní a sociální výchova a její cesty k žákovi. Kladno: AISIS. ISBN 80-239-4908-X. 
132) VAŠUTOVÁ, J., 2004. Profese učitele v českém vzdělávacím kontextu. 1. vyd. Brno: Paido. ISBN 978-80-7315-082-4.

133) VITÁSKOVÁ, K., 2006. Specifické poruchy učení pro výchovné pracouniky. 1. vyd. Olomouc: UP. ISBN 80-244-1216-0.

134) VYGOTSKIJ, L. S., 2004. Psychologie myšlení a řeči. 1. vyd. Praha: Portál. ISBN 80-7178-943-7.

135) VYGOSTKIJ, L. S., 1976. Vývoj vyššich psychických funkcí. Praha: SPN.

136) VÝZKUMNÝ ÚSTAV PEDAGOGICKÝ V PRAZE, 2004. Rámcový vzdělávací program pro předškolní vzdělávání. [online] [vid. 2015-0507]. Dostupné z: http://www.vuppraha.cz/wpcontent/uploads/2009/12/RVP_PV-2004.pdf. V textu uváděno pod zkratkou: RVP-PV 2004.

137) VÝZKUMNÝ ÚSTAV PEDAGOGICKÝ V PRAZE, 2006. Rámcový vzdělávací program pro základní vzdělávání: s př́lohou upravujicí vzdělávání žáků s lehkým mentálním postižením. Dotisk 1. vyd. Praha: Výzkumný ústav pedagogický v Praze. ISBN 80-87000-02-1. V textu uváděno pod zkratkou: RVP-ZV - MP 2006.

138) VÝZKUMNÝ ÚSTAV PEDAGOGICKÝ V PRAZE, 2010. Rámcový vzdělávací program pro základní vzdělávání. 1. vyd. Praha: Výzkumný ústav pedagogický v Praze. ISBN 978-80-87000-37-3. V textu uváděno pod zkratkou: RVP-ZV 2010.

139) WECHSLER, D., 2002. WISC-III. Praha: Testcentrum

140) WEISS G, HECHTMAN L., 1993. Hyperactive Children Grown up: ADHD in Children, Adolescents, and Adults. New York: A Division of Guilford Publications, Inc. ISBN 0-89862-039-2

141) WENDER, P., EPSTEIN, R., KOPIN, I., GORDON, E., 1971. Urinary monoamino metabocites in children with minimal brain dysfunction. American Journal of Psychiatry, 127, s. 1411-1415.

142) WHALEN, C. K., HENKER, B., 1999. The child with attention-deficit/ hyperactivity disorder in family context. In QUAY, H. C., HOGAN, A. E. (Eds) Handbook of disruptive behavior disorders. New York: 
Kluwer Academic Publishers, 1999. s. 139-156. ISBN 978-1-46137214-1.

143) WITT, J. C., MARTENS, B. K., ELLIOTT, S. N., 1984. Factors affecting teachers' judgments of the acceptability of behavioral interventions. Psychology in the Schools. Vol. 20, s. 510-517. ISSN 1520-6807.

144) WORLD HEALTH ORGANIZATION, 2014. Mezinárodní statistická klasifikace nemocí a přidružených zdravotních problémů MKN-10. Aktualizace s platností od 1. dubna 2014. [online]. [vid. 2015-05-10]. Dostupné z: http://www.uzis.cz/cz/mkn/index.html. V textu uváděno pod zkratkou: MKN-10 (2014).

145) XU, Ch., REID, R., STECKELBERG, A., 2002 Technology Applications for Children with ADHD: Assessing the Empirical Support. Education and Treatment of Children, Vol. 25, No. 2 (MAY 2002), s. 224-248, ISSN: 0748-8491.

146) YOO, H. J. et al., 2004. Attention deficit hyperactivity symptoms and internet addiction. Psychiatry and Clinical Neurosciences Vol. 58 No. 5 s. 487-494. [online], [vid. 2014-08-07]. Dostupné z: http://onlinelibrary.wiley.com/doi/10.1111/j.14401819.2004.01290.x/epdf.

147) Zákon 561/2004 Sb., o předškolním, základním, středním, vyšším odborném a jiném vzdělávání (školský zákon), ve znění pozdějších předpisů. In: Sbírka zákonů: Česká republika. [online] [vid. 2015-0416]. Dostupné z: http://www.msmt.cz/file/35181_1_1/.

148) Zákon č. 563/2004 Sb. o pedagogických pracovnících, v platném znění. In: Sbirka zákonů: Česká republika. [online] [vid. 2015-03-16]. Dostupné z http://www.msmt.cz/dokumenty/aktualni-zneni-zakona-opedagogickych-pracovnicich-k-1-lednu.

149) ZELINKOVÁ, O., 2003. Poruchy učení. 10. zcela přepr. a rozš. vyd. Praha: Portál. 263 s. ISBN 80-7178-800-7.

150) ZINBARG, R., E., REVELLE, W., YOVEL, I. et al. 2005. Cronbach's alpha, Revelle's beta, and McDonald's omega: Their relations with each other and two alternative conceptualizations of reliability. Psychometrika [online]. Vol. 70, No. 1, s. 123-133. ISSN 0033-3123 
(tisk), ISSN 1860-0980 (online). DOI: 10.1007/s11336-003-0974-7. Dostupné z http://personalityproject.org/revelle/publications/zinbarg.revelle.pmet.05.pdf.

151) ZOUNEK, J., ŠEĎOVÁ, K., 2009. Učitelé a technologie. Mezi tradičním a moderním pojetím. 1. vyd. Brno: Paido, 2009. 172 s. ISBN 978-80-7315-187-4.

152) ZVÁRA, K., 2002. Měření reliability aneb Bacha na Cronbacha. Informační bulletin České statistické společnost [online]. 2002, Vol. 13, No. 2, s. 13-20, ISSN 1210-8022. Dostupné z $<$ http://www.statspol.cz/bulletiny/ib-02-2.pdf>.

153) ŽLAB, Z., 1982. Narušení grafické stránky řeči. In: Škodová, E., Jedlička, I., 2003. Klinická logopedie. Praha: Portál, s. 357-384. ISBN 80-7478-546-6. 
Determinanty inkluzivního vzdèláváni dětí s ADHD 


\section{Souhrn}

Monografie Determinanty inkluzivního vzdělávání dětí s ADHD se zaměřuje na problematiku inkluzivního vzdělávání žáků se syndromem ADHD. Vychází z vývojové variability těchto dětí a indikuje souvislost mezi jejich osobnostním rozvojem a sociální interakcí především v prostředí mateřské a základní školy. Rozvíjí ověřené pedagogické postupy a intervence vhodné pro vzdělávání dětí s touto poruchou. Důraz je kladen na osobnost učitele jakožto nejvýznamnějšího činitele funkčního procesu inkluzivní edukace žáka s ADHD. Poukazuje na nezbytnost edukačně-intervenčního zaměření výukového procesu směrem osobnostní a sociální výchovy těchto dětí a současné reedukace jejich případných specifických poruch učení coby časté komorbidity ADHD.

Metodou dotazníkového šetření byly na vzorku 240 respondentů z mateřských, základních a praktických škol zjištovány znalosti pedagogů o inkluzivní edukaci dětí a žáků s ADHD. Dotazník se skládal ze tří částí - popisných údajů o respondentovi, standardizovaného a pro české prostředí přizpůsobeného Sciuttova dotazníku KAADS (The Knowledge of Attention Deficit Disorders Scale) a z části zjištující četnosti uplatňování konkrétních zásad edukace žáků s ADHD. Dotazník byl distribuován v elektronické i tištěné verzi.

Data získaná od učitelů byla statisticky zpracována a analyzována. Byly vyhodnoceny znalosti učitelů o problematice ADHD ve vztahu $\mathrm{k}$ různým podpơrným opatřením uplatňovaným při inkluzivním vzdělávání. Byly také identifikovány skupiny pedagogů, které by měly být preferovány při dalším vzdělávání o problematice edukace žáků s ADHD.

Monografie s názvem Determinanty inkluzivního vzdělávání dětí $s$ ADHD vznikla v rámci projektu Cesta k inkluzi: od segregace $k$ pozitivní diverzitě ve školství, reg. č. projektu CZ.1.07/1.2.00/47.0008, který byl spolufinancován z Evropského sociálního fondu a státního rozpočtu České republiky. 


\section{Summary}

The monograph Determinants of the inclusive education of children with $A D H D$ focuses on issues of the inclusive education of pupils with ADHD. Based on the developmental variability of these children, it indicates a relationship between their personal development and social interaction, especially in the environment of nursery and primary schools. There are developed proven pedagogical techniques and interventions appropriate to the education of children with this disorder. Emphasis is given to the personality of teacher who is the most important factor of the functional process of inclusive education of pupils with ADHD. The need is highlighted for both intervention and education process oriented towards personal and social education of these children with simultaneous reeducation of any of their specific learning disorders as a frequent comorbidity with ADHD.

A knowledge of teachers about inclusive education of pupils with ADHD was surveyed in sample of 240 respondents from kindergartens, primary schools and so called practical schools. The questionnaire included three parts - a section with descriptive data about the respondent, a standardized questionnaire KAADS by Sciutto (The Knowledge of Attention Deficit Disorders Scale) customized to the Czech environment and a section aiming to detect the frequency of application the specific education strategies for children with ADHD. The questionnaire was distributed in both electronic and printed version.

The data obtained from teachers were statistically processed and analyzed. There was evaluated the teachers' knowledge about ADHD issues in relation to various support measures adopted in the inclusive education. There were also identified target groups of teachers that should be preferred in further education on the issue of education for children with ADHD.

Monograph entitled Determinants of inclusive education of children with $A D H D$ has been supported within the project Way to Inclusion: From segregation to the positive diversity in education, registration № CZ.1.07/1.2.00/47.0008, which was co-financed by the European Social Fund and Czech state budget. 


\section{Klíčová slova}

inkluzívní vzdělávání; ADHD; speciální vzdělávací potřeby; vývojová variabilita; pedagogická diagnostika; osobnost učitele; dotazník KADDS; specifické poruchy učení; osobnostní a sociální výchova; základní škola.

\section{Keywords}

inclusive education; ADHD; special educational needs; developmental variability; pedagogical diagnostics; personality of teacher; KADDS questionnaire; specific learning disabilities, personal and social education; elementary and middle school. 
Determinanty inkluzivního vzdèláváni dětí s ADHD 
Název: Determinanty inkluzivního vzdělávání dětí s ADHD

Autor: $\quad$ Zdeňka Michalová, llona Pešatová a kol.

Vědecký redaktor: doc. PhDr. Jiří Šskoda, Ph.D.

Vydavatel: $\quad$ Pedagogická fakulta Univerzity J. E. Purkyně v Ústí nad Labem

Místo a rok vydání: Ústí nad Labem, 2015

Náklad: $\quad 200$ výtisků $\quad 2$

Rozsah: $\quad 239$ stran

Tisk: $\quad$ Tribun EU s. r. o., Brno

ISBN 978-80-7414-934-4 (váz./brož.)

ISBN 978-80-7414-962-7 (CD/on-line) 